\title{
Exploring the Experiences of Successful First-Generation College Students At Selected Community Colleges
}

Jennifer Ann Waters

West Virginia University

Follow this and additional works at: https://researchrepository.wvu.edu/etd

\section{Recommended Citation}

Waters, Jennifer Ann, "Exploring the Experiences of Successful First-Generation College Students At Selected Community Colleges" (2012). Graduate Theses, Dissertations, and Problem Reports. 272. https://researchrepository.wvu.edu/etd/272

This Dissertation is protected by copyright and/or related rights. It has been brought to you by the The Research Repository @ WVU with permission from the rights-holder(s). You are free to use this Dissertation in any way that is permitted by the copyright and related rights legislation that applies to your use. For other uses you must obtain permission from the rights-holder(s) directly, unless additional rights are indicated by a Creative Commons license in the record and/ or on the work itself. This Dissertation has been accepted for inclusion in WVU Graduate Theses, Dissertations, and Problem Reports collection by an authorized administrator of The Research Repository @ WVU.

For more information, please contact researchrepository@mail.wvu.edu. 
Exploring the Experiences of Successful First-Generation College Students At Selected Community Colleges

\author{
Jennifer Ann Waters
}

Dissertation submitted to the College of Human Resources and Education at West Virginia University in partial fulfillment of the requirements for the degree of

Doctor of Education

in

Educational Leadership

\author{
Adriane Williams, Ph.D., Chair \\ Ernest Goeres, Ph.D. \\ Lauryl Lefebvre, Ph.D. \\ Jaci Webb-Dempsey, Ph.D. \\ Margaret Glenn, Ed.D., CRC
}

Department of Curriculum and Instruction/Literacy Studies

Keywords: First generation; college student; community college; student success; Tinto; student departure; student retention; financial resources; financial knowledge; academic preparation; academic skills. 


\begin{abstract}
Exploring the Experiences of Successful First-Generation College Students At Selected Community Colleges
\end{abstract}

Jennifer Ann Waters

The purpose of this study was to examine how successful FGCS in community colleges addressed challenges they face in order to complete their degree programs. This study was based upon Titno's (1993) Model of Student Departure and explored what methods and programs were most beneficial in helping FGCS overcome the challenges they faced as they worked on their degrees. This study explored each of the three categories discussed: (a) responsive social support; (b) financial preparation and acquisition; and (c) proactive academic preparation and encouragement through the use of semi-structured individual interviews. A more thorough understanding of how to assist FGCS benefits postsecondary staff and faculty who work closely with students. The results of this study can aid individual staff members as well as departments so they can better use and focus their efforts in assisting FGCS.

The findings in this study are essentially consistent with the findings in current research on first generation students with a few notable exceptions. The findings of this study supported those of other research indicating FGCS are for the most part not academically prepared for college; often have limited financial resources; and are not encouraged to attend college from a young age.

The findings of this study indicate previous research regarding social integration may not apply to FGCS in a community college setting. Although the participants did not fully meet the criteria for social integration, they did found a match between their social values, preferences, and behavioral styles with other members of the community and felt supported in their educational pursuits.

The findings of this study led to a number of implications for action. One implication is that colleges and universities need to do more to help secondary school students learn how to prepare for and what to expect at college. In addition, colleges and universities need to do more to help FGCS transition to the college experience. Colleges and universities also need to evaluate and consider revising how they offer services on campus in order to address FGCS' schedules. One of the most critical steps colleges and universities need to take is to identify students who may need assistance. 


\section{Acknowledgements}

There are a number of people that I would like to thank for their assistance. Several faculty from WVU provided abundant support throughout the process. My special thanks to Dr. Adriane Williams who stepped in as my chair halfway through the project and provided tremendous help, feedback, and support. I would like to thank my committee; Dr. Ernest Goeres, Dr. Jaci Webb-Dempsey, Dr. Margaret Glenn, and Dr. Laurel Lefebvre; for their time, energy, and feedback for the final body of work that follows.

I am also indebted to a number of other people who were associated with the College of Human Resources and Education at one point of my journey or another. Some are still affiliated with the college while others are not: Dr. Elizabeth Jones who worked with me as chair of my committee to begin my dissertation journey; Dr. Richard Hartnett who spent many hours challenging all of us in the program to do our best work; Dr. Paul Chapman who provided encouragement and feedback during the process; and Dr. Helen Hazi who encouraged me and gave me many opportunities to learn about Public School Administration.

I would like to thank the many colleagues and students I have encountered who inspired my interest in helping FGCS. I certainly want to thank my colleagues for the last three and a half years. Thank you for your patience and encouragement to continue the doctoral process. I strongly suspect you are as happy to hear me say I am done, as I am to say it!

Last but certainly not least a big thank you to my family who has supported me throughout my academic and professional journeys regardless of where in the country they have taken me. I suspect you might be even happier than I am to say I have finished this step! 


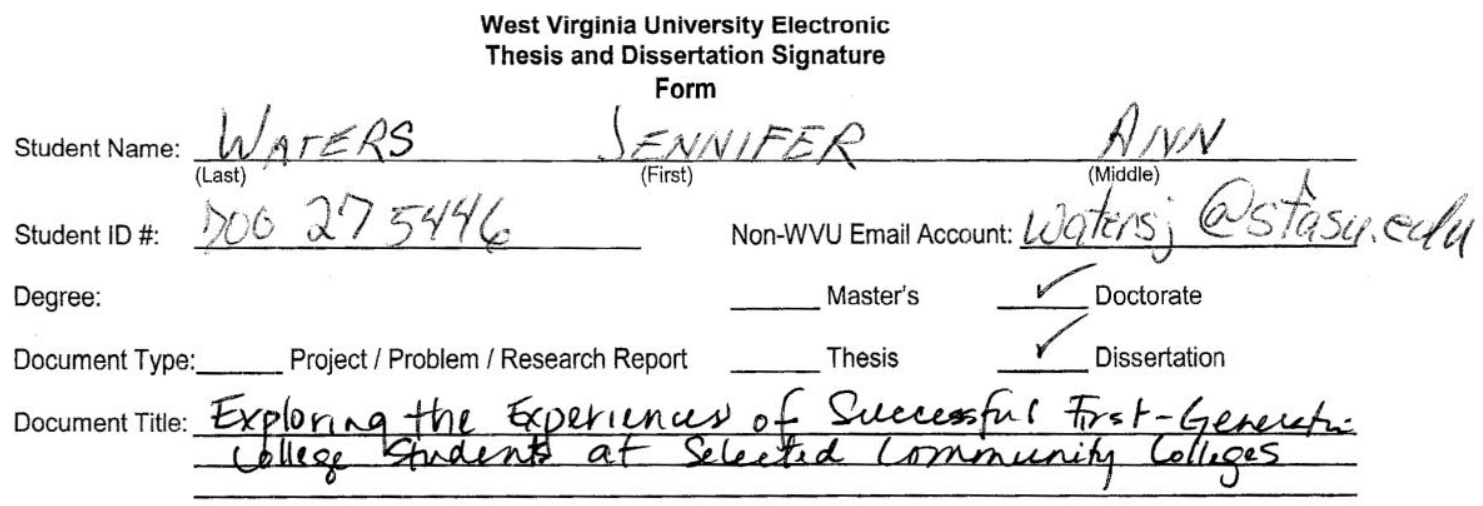

Student Agreement:

I hereby certify that, if appropriate, I have obtained and attached hereto a written permission statement from the owners of each third party copyrighted matter to be included in my thesis, dissertation, project report, or other research material, allowing distribution as specified below.

I hereby grant to West Virginia University and its agents the non-exclusive license to archive and make accessible, under the conditions specified below, my above mentioned document in whole or in part in all forms of media, now or hereafter known. I retain ownership rights as specified in the WVU copyright policy to the copyright of the abovementioned document. I also retain the right to use in future works (such as articles or books) all or part of this abovementioned document.

\section{Student and Committee Agreement:}

Part A. In addition to the unrestricted display of the bibliographic information and the abstract, the student and committee agree that the above mentioned document be placed in the ETD archive with the following status:

(Choose one of 1, 2, or 3).

\section{OPEN ACCESS: Release the entire work immediately for access worldwide.}

2. CAMPUS ACCESS: Release the entire work for West Virginia University access only, except for interlibrary sharing of electronic or printed copies.

3. NO ACCESS: Secure the entire work for patent and/or proprietary purposes for a period of one year. During this period the copyright owner also agrees not to exercise her/his ownership rights, including public use in future works, without prior authorization from West Virginia University. At the end of the one year period, either the student or proxy may request an automatic extension for one additional year.*

*Option 3: At the end of the one-year secure period (or its extension, if such is requested), this work should be handled under: option 1 above (or) option 2 above (initial one choice).

Part B. (Optional proxy). When the student signing this form becomes inaccessible, either of the following persons is authorized by the student to serve as a proxy to modify the release status of this work.

Printed name of proxy:

Printed name of proxy:

WVU will assume no responsibility for any fiscal or other losses incurred by the document's author caused or exacerbated by a proxy's recommendation. 
Review and Acceptance:

The above mentioned document has been reviewed and accepted by the student's advisory committee. The undersigned agree to abide by the statements above, and agree that this Signature Form updates any and all previous Signature Forms submitted heretofore.

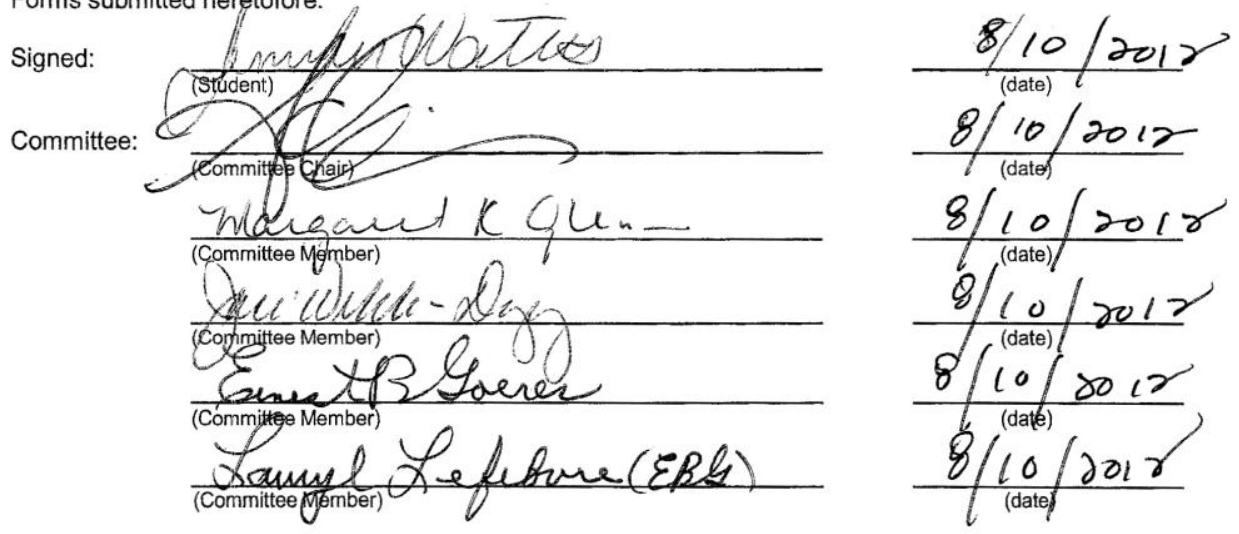

D THE ENTIRE SUBMISSION PACKET MUST BE DELIVERED IN PERSON, BY MAIL OR ELECTRONICALLY TO:

West Virginia University Libraries, Attn: Molly Dolan

Downtown Campus Library

P.O. Box 6069 / 1549 University Avenue Morgantown, WV 26505-6069

Fax: (304) 293-4881 / Email: Molly.Dolan@mail.wvu.edu

Disclaimer: Any unauthorized modification made to the policy content portion of this form renders the document invalid and will result in the use of the original WVUETD policy in effect at the time of submission. 


\section{Table of Contents}

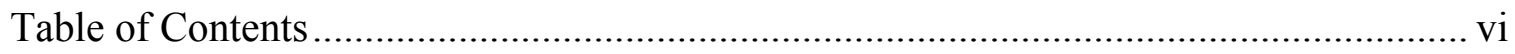

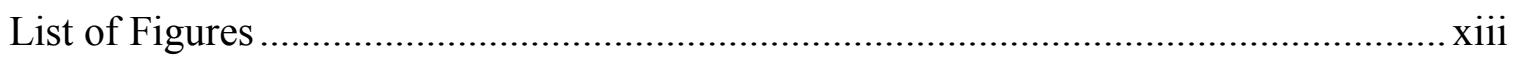

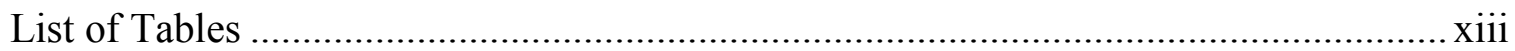

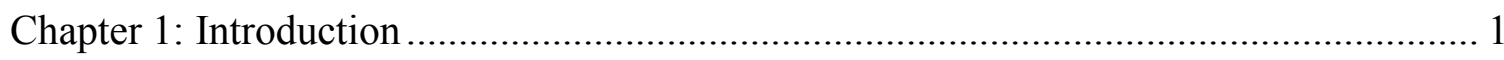

Statement of Problem........................................................................................... 1

Purpose

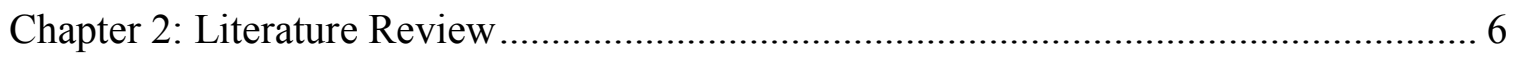

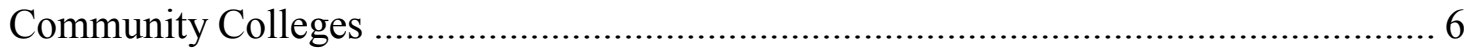

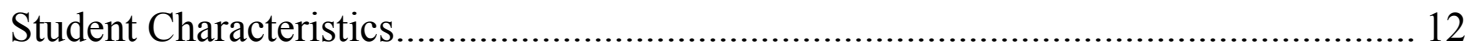

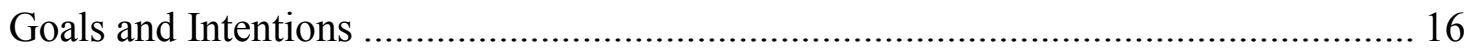

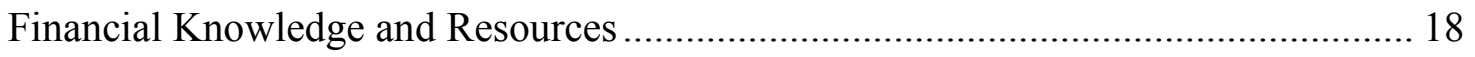

Tinto's Model of Student Departure ………….................................................... 22

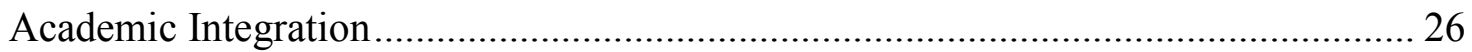

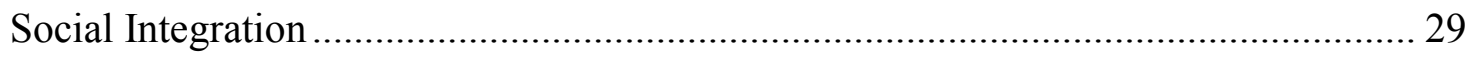

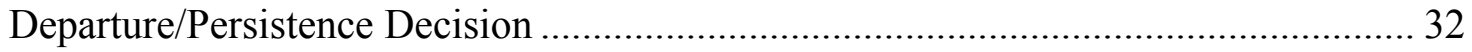

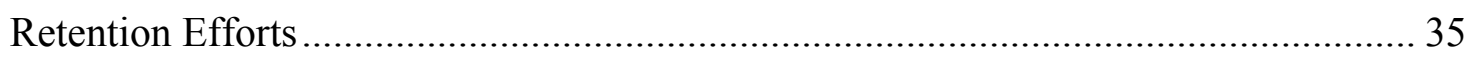

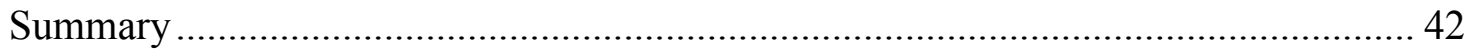

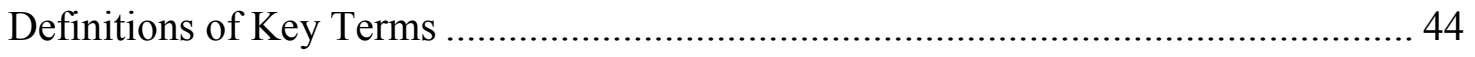

Chapter 3: Research Design and Methodology ………................................................. 48

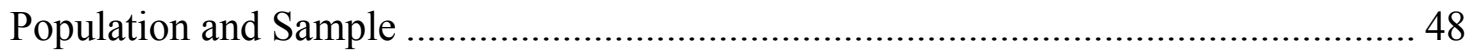

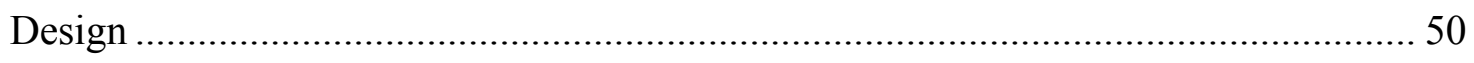

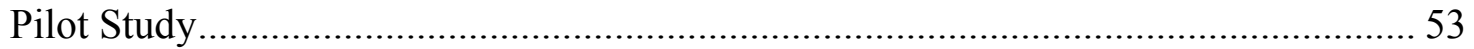




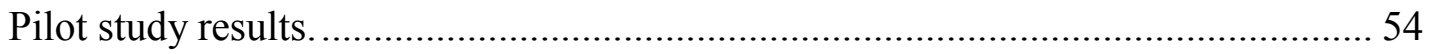

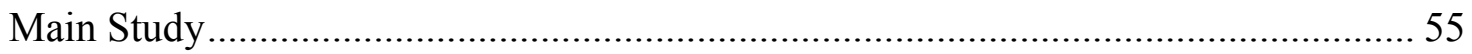

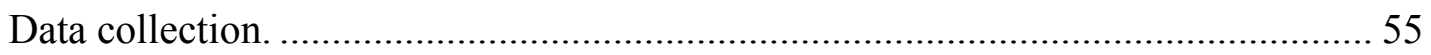

Data analysis and interpretation........................................................................... 57

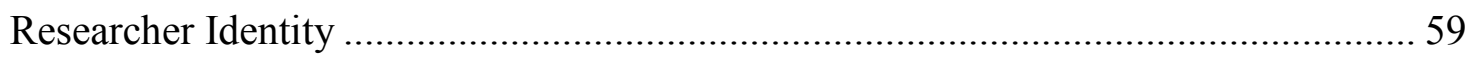

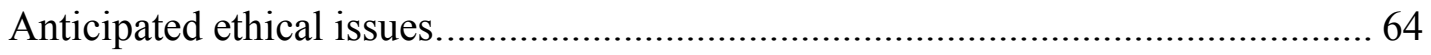

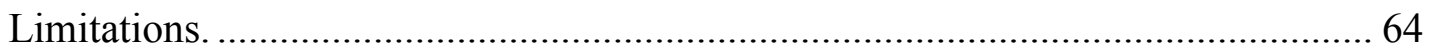

Chapter 4: Community College of the Great Lakes........................................................ 66

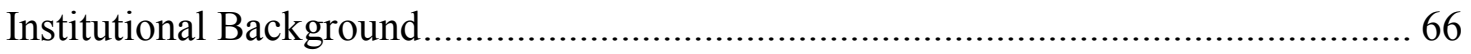

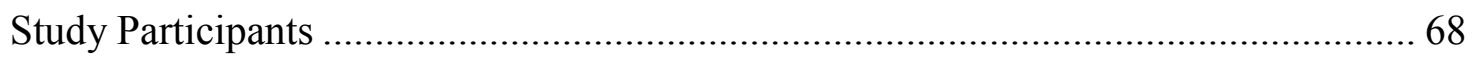

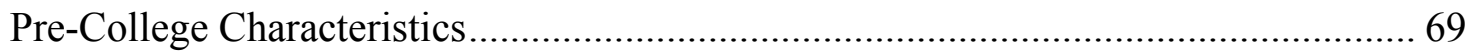

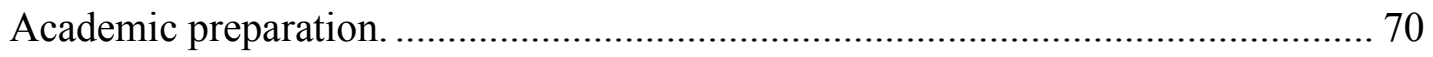

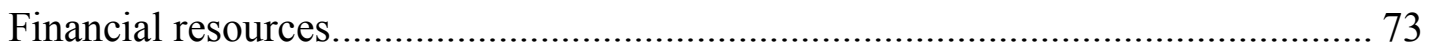

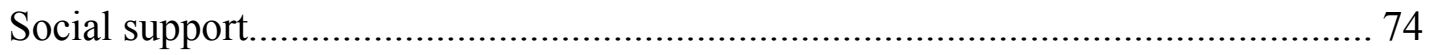

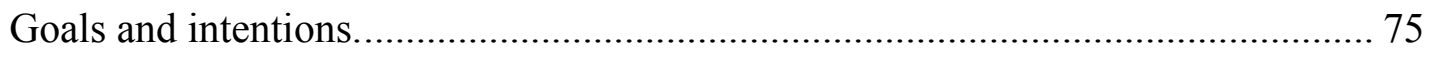

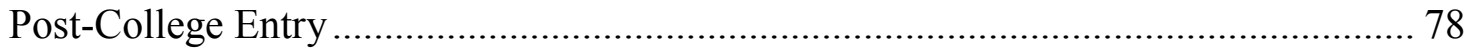

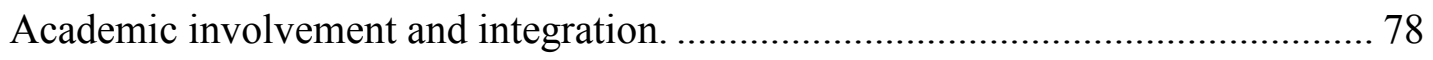

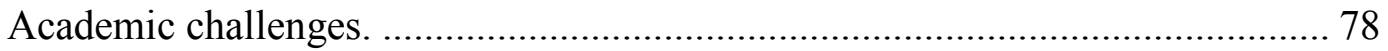

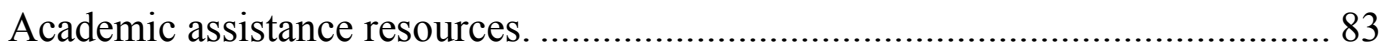

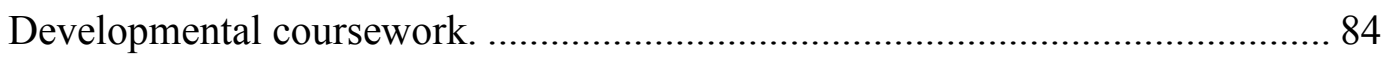

Interaction with faculty, staff, and administrators.............................................. 85

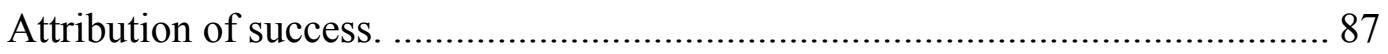

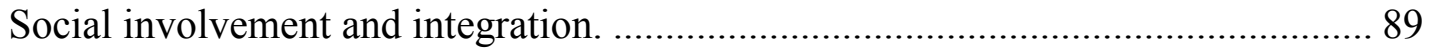




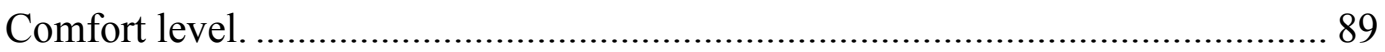

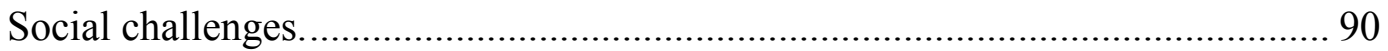

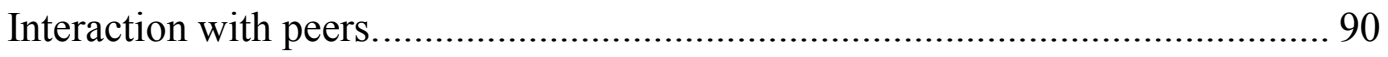

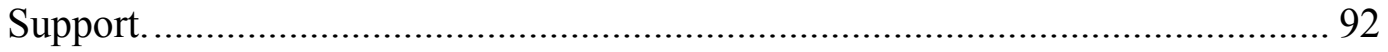

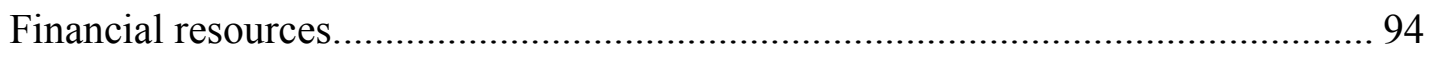

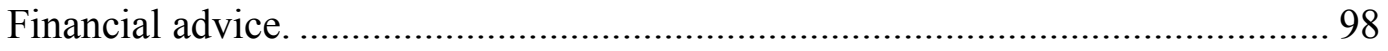

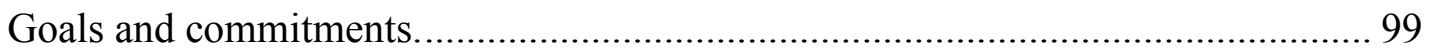

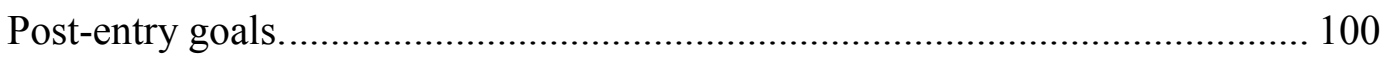

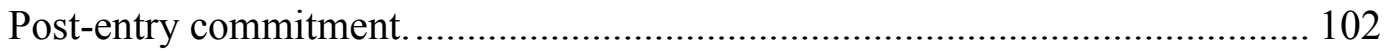

Chapter 5: Community College of Appalachia............................................................ 106

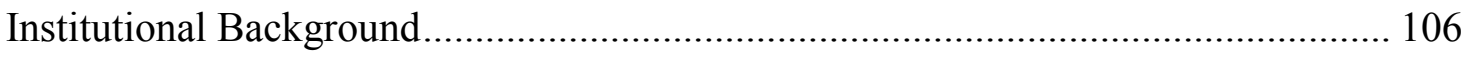

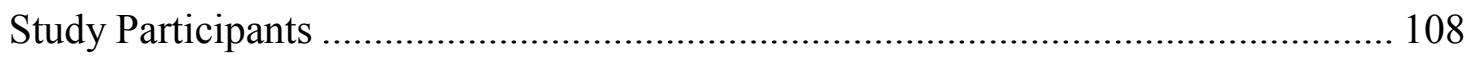

Pre-College Characteristics............................................................................ 110

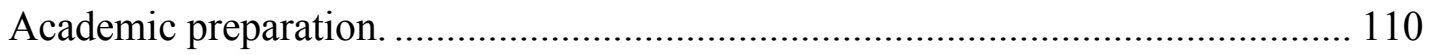

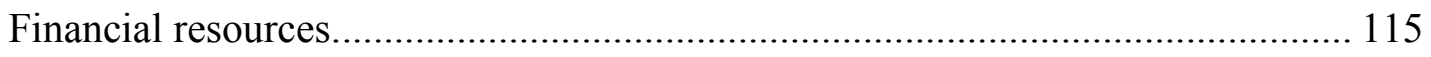

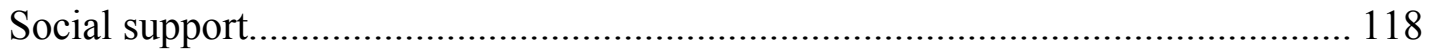

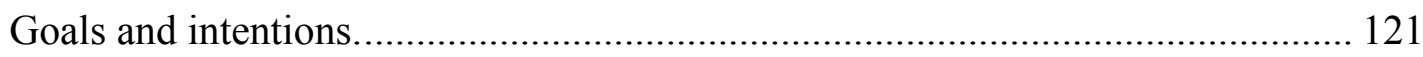

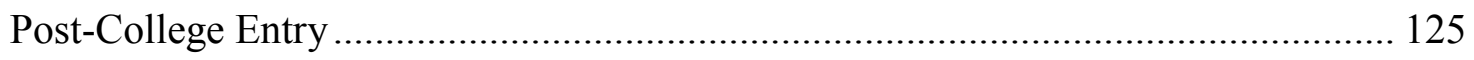

Academic involvement and integration. ........................................................... 125

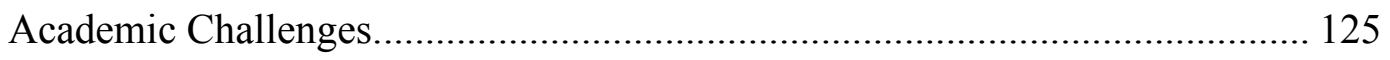

Academic assistance resources. .................................................................... 130

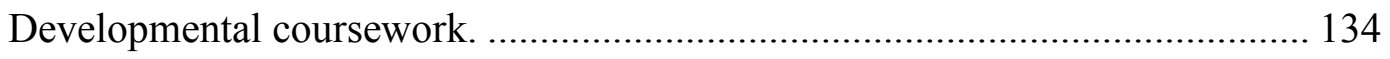

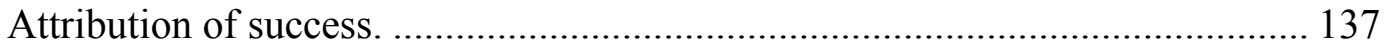




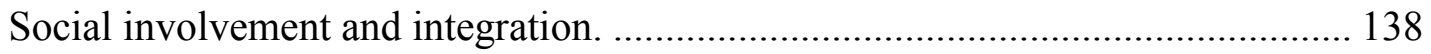

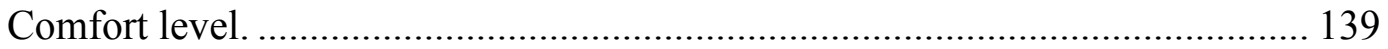

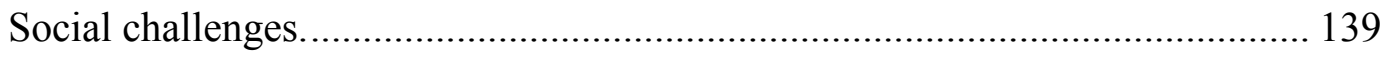

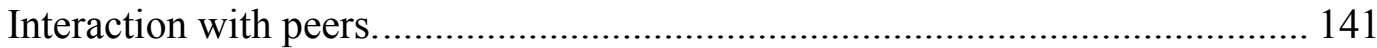

Support.

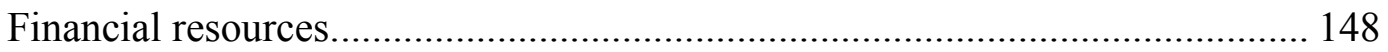

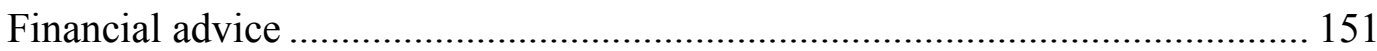

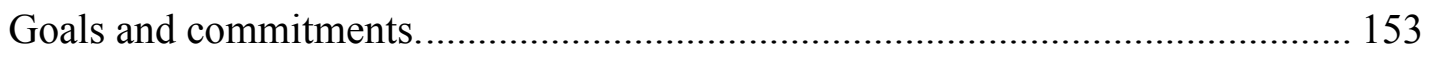

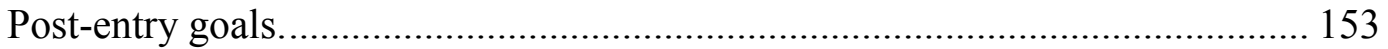

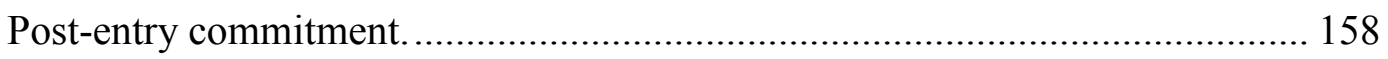

Chapter 6: Southern Community College ............................................................... 165

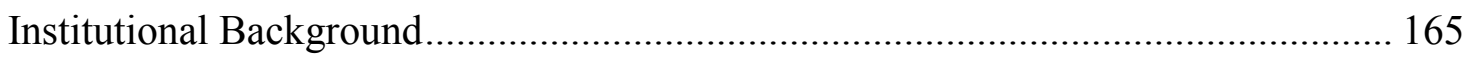

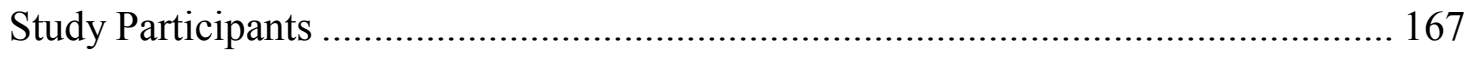

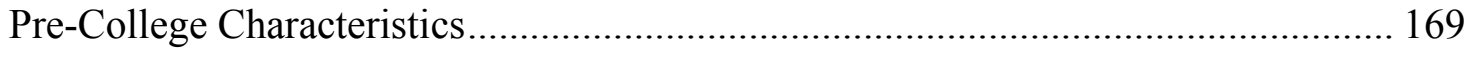

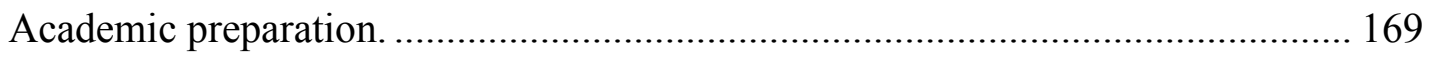

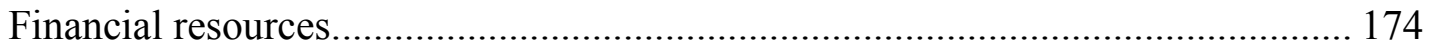

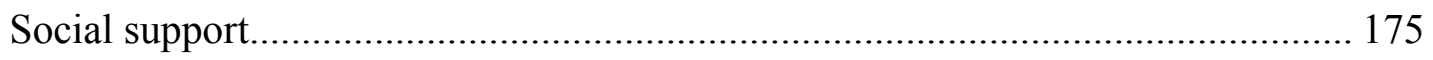

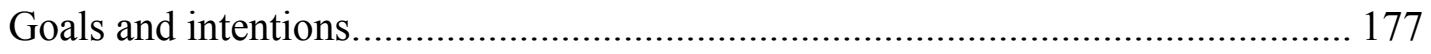

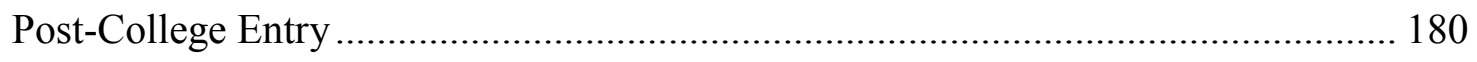

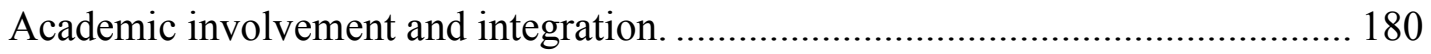

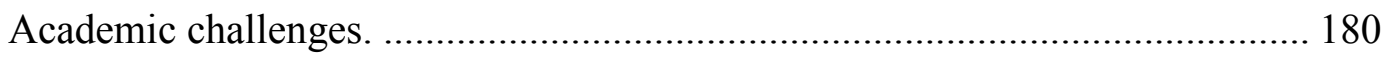

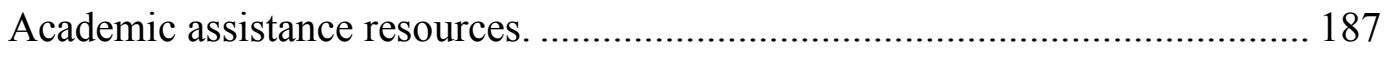

Developmental coursework. ...................................................................... 190 
Interaction with faculty, staff, and administrators.......................................... 190

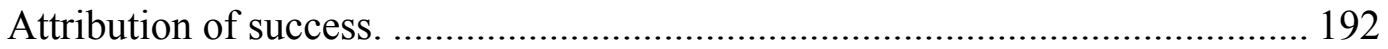

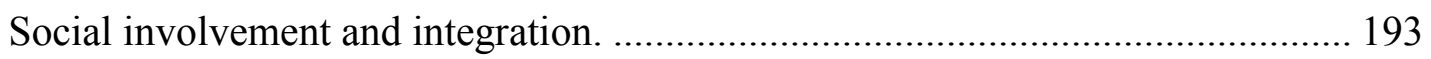

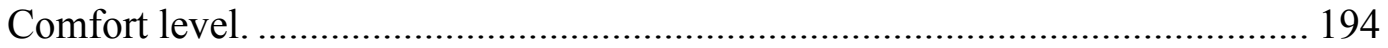

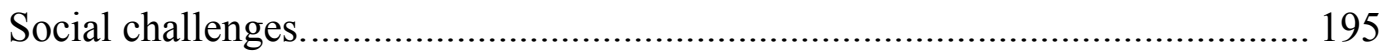

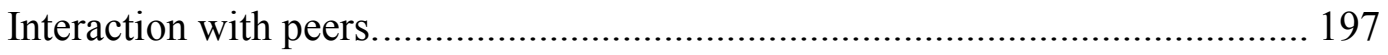

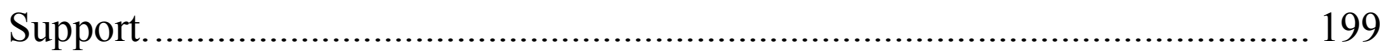

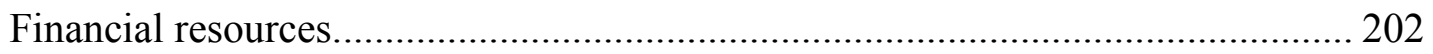

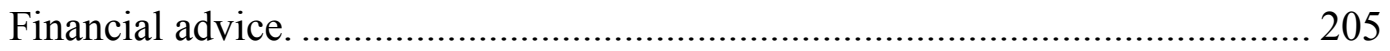

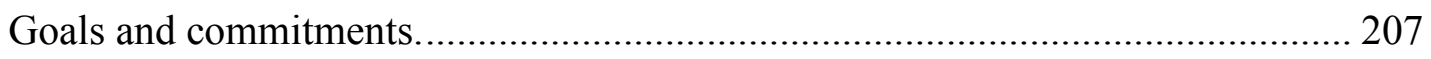

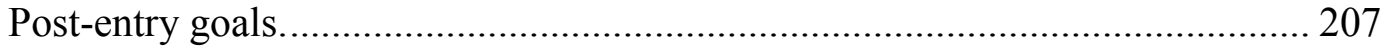

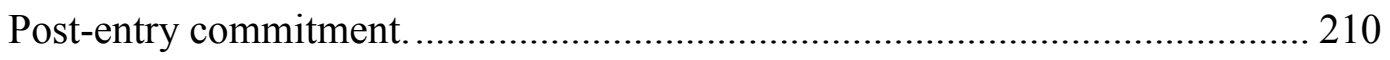

Chapter 7: Summary, Conclusions, and Recommendations .......................................... 215

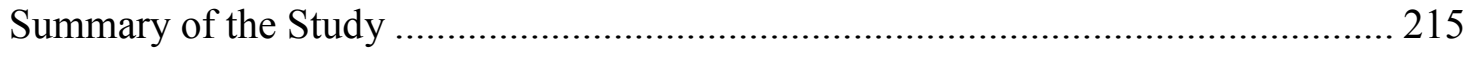

Purpose statement and research questions......................................................... 216

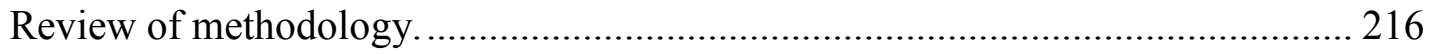

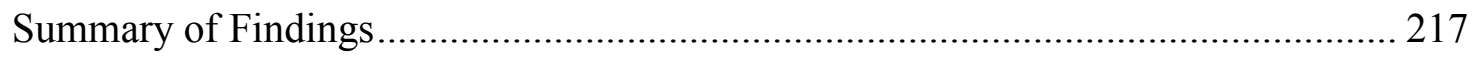

Pre-College Characteristics.............................................................................. 217

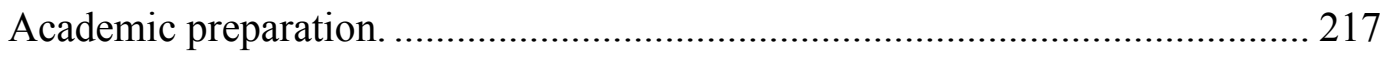

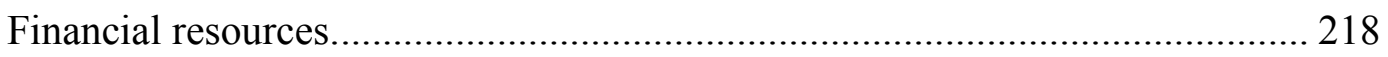

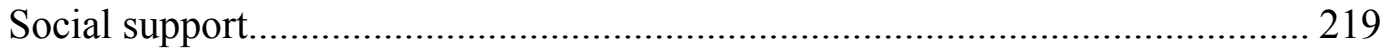

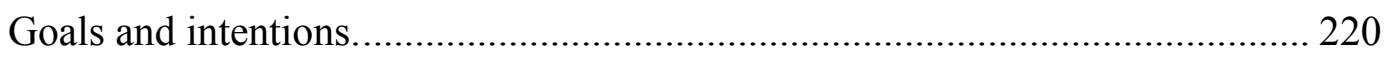

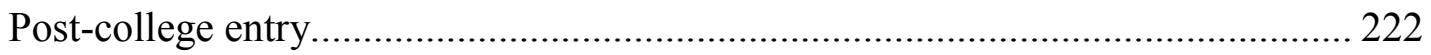




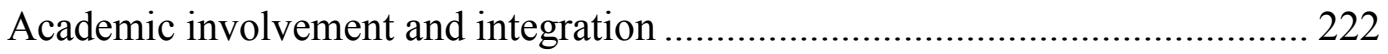

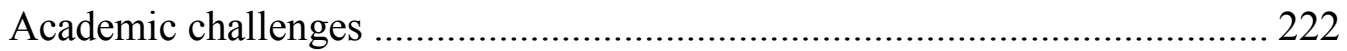

Academic assistance resources. .......................................................... 224

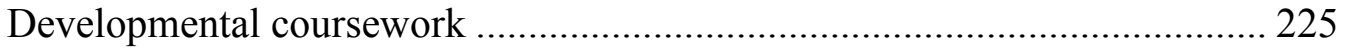

Interaction with faculty, staff, and administrators ................................ 226

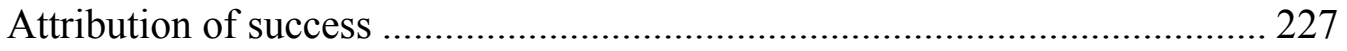

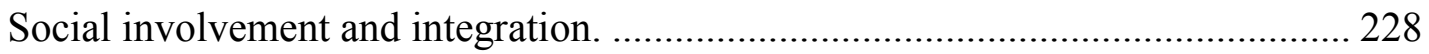

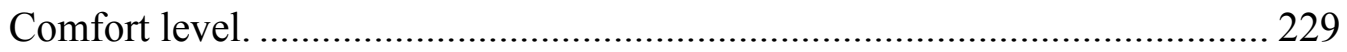

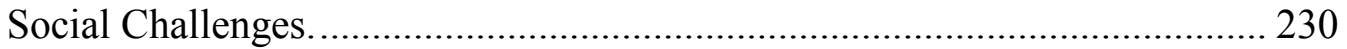

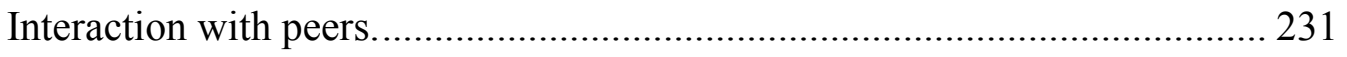

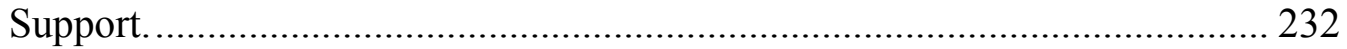

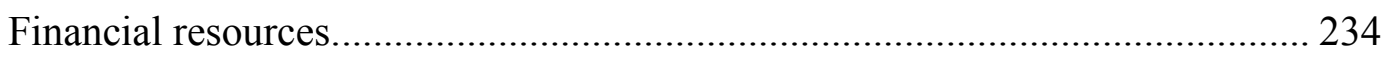

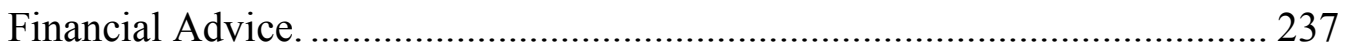

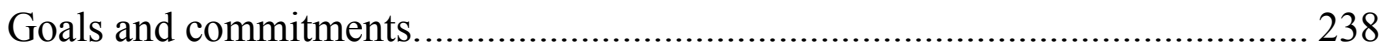

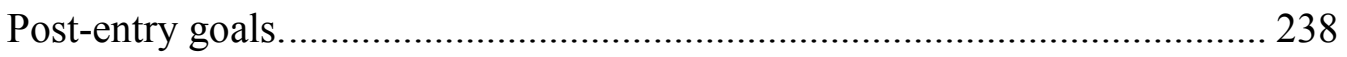

Post-entry commitments. ............................................................ 238

Similarities and Differences Across Sites....................................................... 241

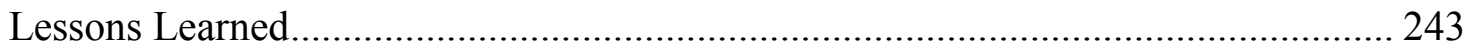

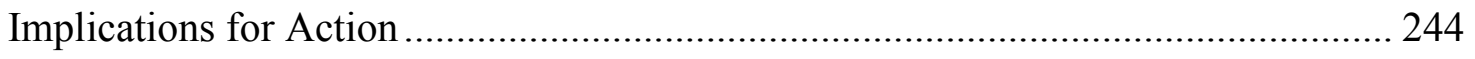

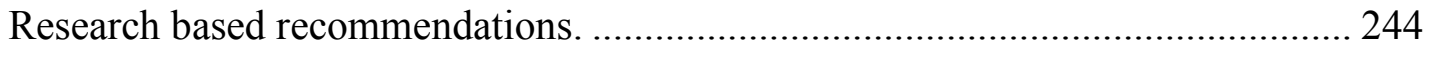

Professional experience based recommendations. ........................................... 246

Recommendations for Further Research................................................... 247

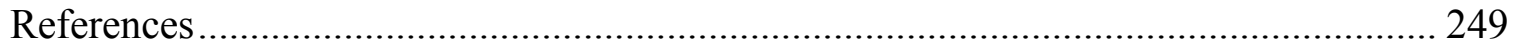




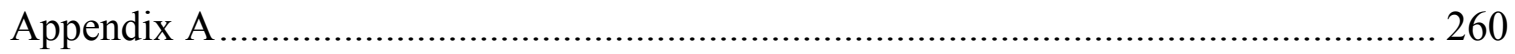

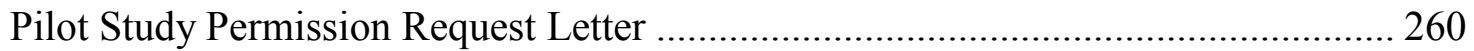

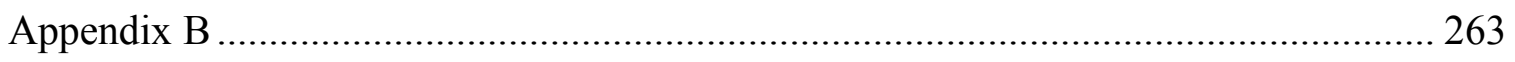

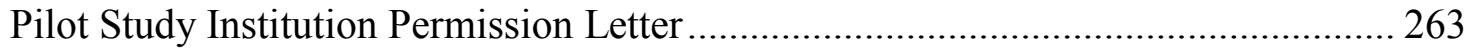

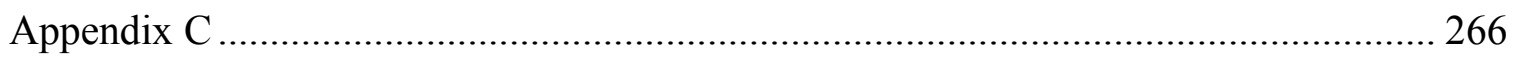

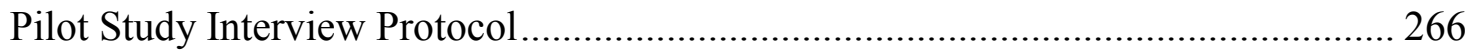

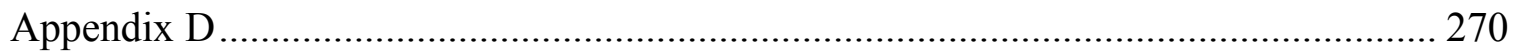

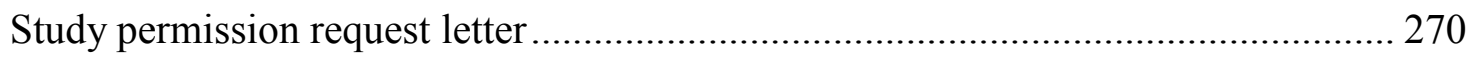

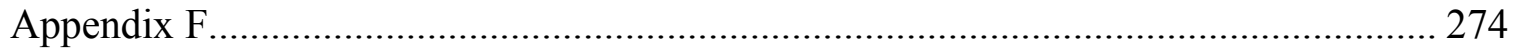

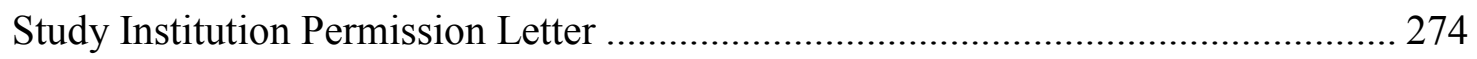

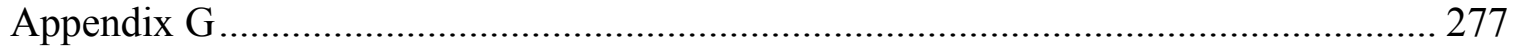

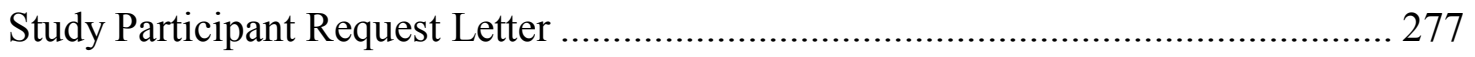

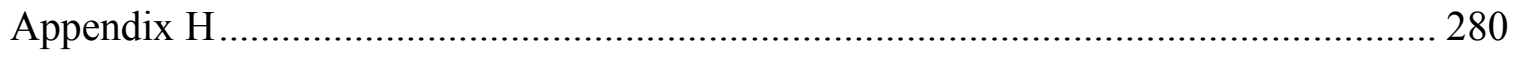

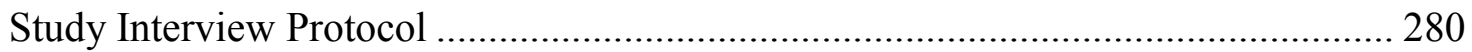

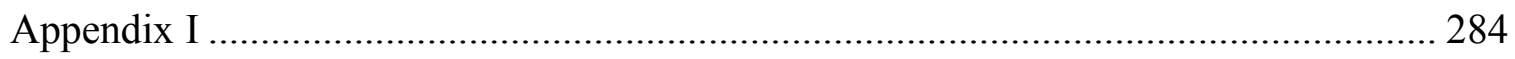

West Virginia University Institutional Review Board Approval............................... 284

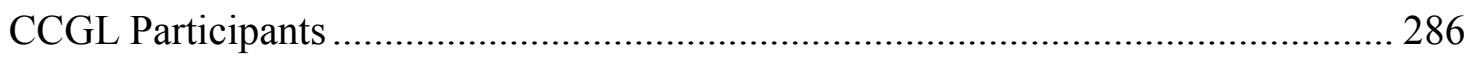

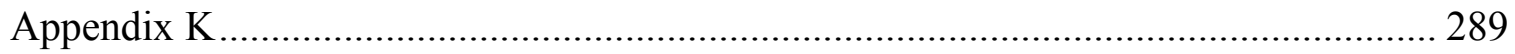

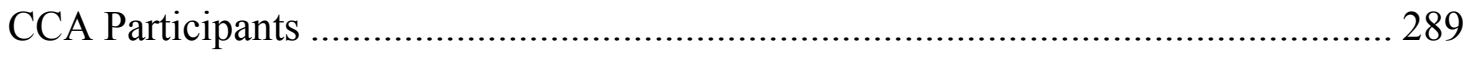

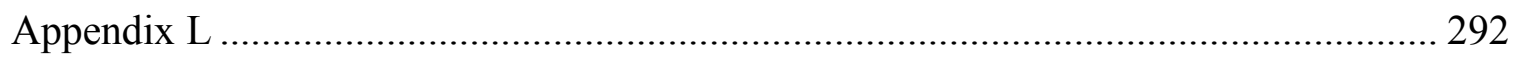

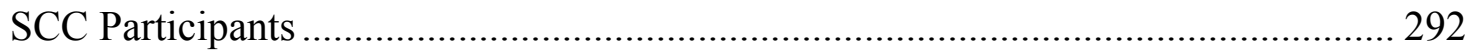




\section{List of Figures}

Figure 1. Conceptual framework of study for FGCS retention based upon Tinto's Model of Student Departure. Error! Bookmark not defined.

\section{List of Tables}

Table 1 Research question - Interview Question Congruence 53

Table 2 Characteristics of Participating Community Colleges ............................................. 56

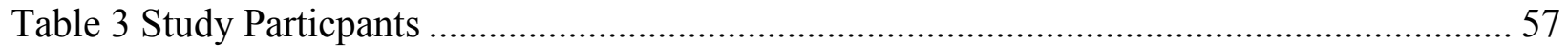

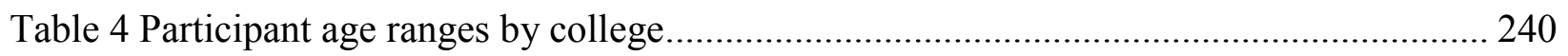




\section{Chapter 1: Introduction}

\section{Statement of Problem}

Beginning as early as the federally sponsored G.I. Bill of 1944, colleges have been increasingly accessible to a wider variety of students. The G.I. Bill provided educational and training benefits to eligible veterans after World War II. Murray (2008) explained prior to the bill, seeking a college education tended to be limited to the social and economic elite. The G.I. Bill made college available to more people and made more colleges financially accessible to those seeking a college education (Murray, 2008).

Today's college and university campuses continue to have more diverse student populations. This expansion of the diversity of student populations reflects the increasing diversity of the population in general. As students with diverse backgrounds enter postsecondary education, colleges and universities must address their various needs. One group of students present in increasing numbers on college and university campuses is first-generation college students (FGCS). FGCS are those students who are within the initial age group of their family to seek postsecondary education. Nearly one quarter of the students who entered college between 1992 and 2000 were FGCS (National Center for Educational Statistics, 2005a).

Although some research has begun to describe the challenges faced by FGCS, very few studies have examined how successful FGCS address the challenges they face in order to complete their degree programs. Research has identified lack of social support, financial knowledge, and academic preparation as some of the key challenges faced by FGCS (Chen \& Carrol, 2005; Hertel, 2002; Horn \& Nunez, 2000; and others). They have few friends, family, or mentors who are available to discuss potential problems and to help develop solutions for issues regarding entry into college and completion of degree programs. This breakdown in social 
support begins before students enter college. Even in high-school, FGCS do not have as much support as do their counterparts who have college graduate parents. FGCS often do not have parents advising them on courses needed to prepare for college. They are less likely than other students to report choosing their high school programs with parents (Horn \& Nunez, 2000). Family members of FGCS may support the student's decision to attend college but are unable to provide advice on how to handle the demands the student will face at college. An additional source of support for college-bound students is that of mentors. However, FGCS are no more likely to report high school counselor assistance in selecting an institution than their non-FGCS counterparts (Horn \& Nunez, 2000). The lack of social support continues once FGCS begin college. Students who are not the first in their families to attend college find support from friends who are also attending college. However, FGCS report having less support from friends attending colleges than do the other students. This becomes a concern when viewed along with the results of Hertel's study (2002). In this study, Hertel found support from on-campus friends significantly added to the prediction of overall adjustment and attachment to college which leads to increased persistence. Research has shown FGCS are lacking support from each of the areas upon which other students are able to rely.

Another challenging area for FGCS is that of preparing financially for a college education. Many students rely heavily on their parents to cover the expenses associated with receiving a college education. However, FGCS often have fewer family related financial resources than other students. Horn and Nunez (2000) reported half of high school graduates who do not have college graduate parents come from low-income families. In fact, FGCS are more likely to have annual family incomes of less than $\$ 60,000$ and are less likely to receive financial support from their parents (Humphrey, 2000). As a result, FGCS must rely on 
themselves or sources other than their parents for financing their education. FGCS are less likely to use financial resources requiring repayments and likely to use resources not requiring repayments such as Pell Grants, Supplemental Educational Opportunity grants, state scholarships, and other grants. In addition, FGCS are more likely to work part-time or full-time while in college (Humphrey, 2000; Nunez \& Cuccaro-Alamin, 1998). However, research studies found that working an increased number of hours tends to have a negative impact on FGCS (Hertel, 2002; Pascarella, Pierson, Wolniak, \& Terenzini, 2004). Financial concerns even factor into FGCS' choice of institutions. Humphrey found being offered financial aid is an important factor for FGCS in selecting a college or university.

An additional challenge FGCS experience develops from their poor preparation for the demands of college. Their poor preparation is demonstrated across the curriculum. In their study of high school students, Chen and Carrol (2005) reported FGCS are less academically prepared for college than their non-FGCS counterparts. They often do not take the appropriate classes to prepare them for college. In 2000, Horn and Nunez reported that $63 \%$ of FGCS were not likely to complete any advanced-level mathematics courses in high school. Humphrey (2002) found they are less likely to have completed the recommended courses in English, foreign languages, arts, and music prior to attending college. In terms of general academic preparation, FGCS are reported as having lower critical thinking abilities than non-FGCS (Terenzini, Springer, Yeager, Pascarella, \& Nora, 1996). As they prepare to enter college, FGCS are more likely to have lower grade-point averages (GPAs), and lower Math and Verbal SAT scores than non-FGCS (Humphrey, 2000).

FGCS are not surprised by their poor academic preparation. Humphrey (2002) reported they often rate themselves as lacking in academic skills needed for college. They are also less 
likely to consider themselves above average in their mathematical ability and more likely to consider themselves as average or below average in writing ability, creativity, and public speaking ability (Humphrey, 2000).

The combination of challenges in social support, financial knowledge, and academic preparation FGCS experience often lead to difficulties in not only entering college, but also completing degrees. Nunez and Cuccaro-Alamin (1998) found FGCS are less likely to persist in college and attain degrees than other students. FGCS are likely to leave college between their first and third years with the highest number leaving in their second year and are 8.5 times more likely to leave college than non-FGCS (Ishitani, 2005). As a result of their lower persistence rate, FGCS are classified as at-risk students (Terenzini et al., 1996). With nearly one fourth of entering college students being FGCS (NCES, 2005a) and FGCS more than twice as likely to choose two-year institutions (Ishitani, 2005), colleges and universities must intervene in order to help FGCS overcome these challenges and to earn degrees.

\section{Purpose}

The purpose of this study is to examine how successful FGCS in community colleges have addressed challenges they face in order to complete their degree programs. Success is defined as students who depart the institution as a result of completing a degree, program, or credential area or as a result of transfer to a four-year institution to pursue a Bachelor's degree. This study explored what methods and programs have been most beneficial in helping FGCS overcome the challenges they face as they work on their degrees. It will examine each of the three categories discussed: (a) responsive social support; (b) financial preparation and acquisition; and (c) proactive academic preparation and encouragement. A more thorough understanding of how to assist FGCS will benefit postsecondary staff and faculty who work 
closely with students. The results of this study will aid individual staff members as well as departments so they can better use and focus their efforts in assisting FGCS thus leading to more successful FGCS.

Tinto (1993) suggested students are more likely to persist in their education if they are integrated into both the social and academic systems of the institution. The framework for this study is based upon Tinto's (1993) model of student departure. Tinto's model of student departure focuses on the importance of students being academically and socially integrated into the college in order to be successful. Once students enter college, their personal characteristics interact with the academic and social systems of the college to influence whether or not their goals change and whether or not they persist or depart from the college. This research will examine which programs and services at colleges contribute to students' decisions to persist at an institution. In order to gain a better understanding of how first-generation college students have been assisted the primary research question for this study is: how have successful first-generation community college students overcome their academic, financial, and social challenges in order to be successful? 


\section{Chapter 2: Literature Review}

The literature review begins with an overview of community colleges and continues with a summary of the characteristics found in undergraduates (including first generation college students) who enroll in colleges and universities in the United States. Next, the literature review presents an overview of Tinto's (1993) model of college student departure. Variables from this model including students' academic preparation, financial knowledge and resources, and social support will also be discussed. The literature review will conclude with an examination of persistence trends and retention activities taking place on many campuses.

\section{Community Colleges}

American community colleges date from the early $20^{\text {th }}$ century (Cohen \& Brawer, 1996). In their early days, community colleges were considered junior colleges and their mission was to provide the first two years of a liberal arts education (Boggs, 2011; Mullin, 2010). Over the course of time, the mission, goals, and intent of community colleges have changed dramatically. Today, community colleges' missions are more wide ranging and varying (Levin, 1997). In addition to continuing to prepare students for transfer to a four-year college or university, community colleges provide certificate and degree programs that combine liberal arts and more focused programs for specific technical or educational skills (Boggs, 2011).

Community colleges of today play many roles. Although the open door, open access component of community colleges' missions remain, other missions are developing and taking on increased importance for community colleges across the U.S. (Torres \& Evans, 2005). They have modified their missions to include workforce development, community development and inclusion, and developmental education along with lifelong learning opportunities. Community colleges have adopted access, inclusion, community responsiveness, innovation, small class size, 
focus on instruction, and student learning and success as values (Boggs, 2011). In addition, many community colleges work closely with state departments to consolidate programs, provide office space for new businesses, and track economic trends and legislation that may impact the local economy (Miller \& Tuttle, 2007).

The heart of the mission for many community colleges is a sense of responsibility for the economic development or the region surrounding the college (Boggs, 2011). As a part of their concern for the economic development of their region, community colleges provide a variety of noncredit programs and courses for specialized careers (Boggs, 2011). Community colleges design career programs and provide contract education to local businesses to meet businesses' specific work force needs and to focus on the region's strengths (Boggs, 2011 and Kennamer, \& Katsinas, 2011). This sense of responsibility to help the region's economic development may be especially challenging for rural community colleges. Rural areas tend to have low population numbers, low educational attainment, high rates of illiteracy, slow job growth, low per-capita income, and high rates of poverty that have increased every year since the 1960's (Kennamer, \& Katsinas, 2011).

Community colleges, especially rural community colleges, include their communities in campus life, promote pride in the community, and enhance the quality of life for members of the surrounding community (Miller \& Tuttle, 2007). They accomplish this task in part by providing facilities for community activities, providing job training and retraining programs, providing civic activities, and providing personal development courses based upon community interest (Miller \& Tuttle, 2007). For communities surrounding community colleges, this may be a critical asset to having a community college nearby. By the fall of 2007, approximately five million noncredit students were enrolled in community colleges across the United States (Boggs, 2011). 
Community colleges play a critical role in helping the U.S. have an educated population (Mullin, 2010). At one time, earning a high school degree was adequate to allowing people to live a middle-class lifestyle. High school graduates earn almost 50\% more than those who did not complete high school (Mullin, 2010). These increased wages result in additional revenue for government through taxes (Mullin, 2010). Today, although a high school education is necessary, many view higher education as essential to allowing people to reach a middle-class lifestyle (Mullin, 2010). In order to maintain access to higher education for populations that may not have access to college otherwise, community colleges are being pushed to offer more on-line and noncredit classes.

Community colleges are also critical elements in the economic success of the United States (Boggs, 2011). Community colleges have been included in the presidential mandate to increase the number of college graduates by the year 2020. As their contribution to increasing the number of college graduates, community colleges have been called upon to double the number of students who earn a certificate or associate's degree or transfer to a four-year college to earn a bachelor's degree (Kotamraju \& Blackman, 2011and O'Banion, 2011). In order to meet the educational goals set for the U.S., the number of bachelor and lower degrees will need to increase each year by $16 \%$ (Kotamraju \& Blackman, 2011). This means community college must increase their graduation levels from 1.5 million per year to nearly 1.75 million per year by 2020 (Kotamraju \& Blackman, 2011). This goal will not be met without difficulties as the U.S. economy struggles. Research has shown that states with higher unemployment rates tend to have lower graduation rates (Kotamraju \& Blackman, 2011). In addition, community colleges must ensure their doors remain open to a variety of students if they hope to meet these goals (England - Siegerdt, 2011). 
In spite of the anticipated growth of community college, the outlook for them is not entirely positive. At the same time the mission and goals of community colleges are changing, their leadership is as well. For many proponents of community colleges one of the most critical concerns for the survival of community colleges is the perceived lack of leaders. Those people who have served in leadership positions at community colleges during their rapid growth of the last few years are retiring in large numbers. In addition to losing large numbers of veteran community college leaders, many educational programs are not training people to be effective community college leaders and the number of programs that are preparing community college leaders is dropping (Torres \& Evans, 2005). This leads to a vacuum of leadership for community colleges.

In terms of interest in attending community colleges, they are increasingly popular among people seeking postsecondary education. By 2009, there were almost 12 million students enrolled at community colleges (Boggs, 2011). There increase in enrollments is not expected to end. The number of students enrolled at community colleges is expected to increase between $10 \%$ and $18 \%$ within the next ten years (Kotamraju \& Blackman, 2011). They have a number of characteristics that make them more appealing than four-year colleges for some students. These characteristics include their cost, location, inclusiveness, and focus on educational achievement as opposed to degrees (Boggs, 2011).

Two of the characteristics that make community colleges more appealing to some students are their lower cost of tuition and their convenience. In general, community colleges are often less expensive than their four year counterparts. In the fall of 2009 , the average cost of tuition at community colleges were almost one third of the average cost of tuition at four year colleges. This makes community colleges a more affordable option when seeking postsecondary 
education.

Not only are community colleges less expensive, but students also often find them more convenient. They are often close to students' homes and work and offer flexible schedules. Approximately $90 \%$ of the U.S. population lives within 25 miles of a community college (Boggs, 2011). An additional component of their convenience is that community colleges are often flexible in their class offerings. At $45 \%$ of public community colleges, students can earn a degree entirely on-line. Even for those students whose programs are not entirely on-line, they benefit from some on-line options. In all, approximately $97 \%$ of community colleges offer at least one on-line course. This allows students to meet educational demands at a time and place that is most convenient for them.

Another characteristic that makes community colleges more appealing for many students is their inclusiveness (Boggs, 2011). Community colleges have traditionally had open door policies. With their open access, community colleges make higher education obtainable to groups that have been historically under-represented at other colleges. Through their increased access for under-represented groups, community colleges serve a diverse group of students who have a wide range of personal and professional needs and goals (Torres \& Evans, 2005).

Another characteristic that make community colleges more appealing to some students is their educational environments. The educational environment of a community college is often different than one found in a four-year college as a result of class size and faculty focus. Because the size of lower level classes are often much smaller than those at four year colleges, students have more opportunities to build one-on-one relationships with their faculty. Faculty at community colleges typically have at least a master's degree in their fields so are very knowledgeable. However they focus specifically on teaching, not on research or publication as 
their counterparts at four year institutions do. In addition, community colleges rely heavily on adjunct faculty to teach industry specific skills. These adjunct faculty are valued for their knowledge and expertise in the fields they teach (Boggs, 2011). The hands on experience of adjunct faculty and the high regard in which they are held allows full-time faculty to be informed and up to date about current needs and demands in the community's industry (Boggs, 2011).

Although access is still an important element of community colleges, they have changed their focus. Since their original founding, community colleges have changed their focus from providing access to higher education or underrepresented groups to ensuring those students are successful once they gain entrance to higher education (Boggs, 2011). With their increased focus on student success, community colleges must redesign their policies, programs, and practices to create a pathway to students successfully completing their programs (O’Banion, 2011). Their shift in focus required community colleges to accept responsibility for student learning and promote practices such as collaborative learning and learning communities. With their change of focus, community colleges have added developmental education to prepare students for college level work, community service courses to serve their surrounding communities, and contracted classes to meet the needs of local industry (Boggs, 2011).

Developmental courses are an important component to helping students find success. More than half of community college students need remedial classes in order to be successful in college (Mullin, 2010). Community colleges' focus on helping students find academic success extends to helping them complete high school (Mullin, 2010). This focus on helping students develop the skills they need to be successful will prove to be a critical element in increasing their graduation rates. In order to double their number of graduates, community colleges must maintain academic and student support programs (Kotamraju \& Blackman, 2011). 
Funding for community colleges has not kept pace with the increased demands being placed on them and their increased enrollment numbers. Torres and Evans (2005) described community college funding as at a much lower level than public four year colleges. Community colleges are funded at 1/5 of the amount of public four year colleges (Mullin, 2010).

\section{Student Characteristics}

Traditionally, college students have come directly from high school with few responsibilities, fallen between the ages of 18 and 22, and attended college full-time. However, since 1989, an increasing number of students who enroll in colleges and universities do not fit this mold (Horn \& Berger, 2004). The number, ethnicity, age, and goals of students have changed. Between 2000 and 2010, enrollment in postsecondary education increased by $37 \%$ to reach 21.0 million students (Snyder \& Dillow, 2012). However, these students represent much different demographics than have past student populations. The percentage of Hispanic and Black students increased to each represent $14 \%$ of the student population in 2010 (Snyder \& Dillow, 2012). Culp (2005) reported 30\% of community college students are members of a minority group. Between 1985 and 1999, the percentage of 18 year olds dropped to represent $45 \%$ while the percentage of 19 year olds increased to represent $22 \%$ of the beginning student population across all types of institutions (Horn \& Berger, 2004). By 2010, the number of 18 to 24 year olds increased by $12 \%$ to reach 30.7 million students (Snyder \& Dillow, 2012).

Community colleges have not been immune to the changes in students' characteristics.

Over the course of time, the student body of community colleges have become the most diverse of postsecondary educational institutions. Community college students are diverse in regards to age, gender, ethnicity, generational status, attendance patterns, and familial status (Boggs, 2011, Kotamraju \& Blackman, 2011; and Torres \& Evans, 2005). Community college students 
represent a wide range of ages. Less than half (43\%) of community college students are under 21 years old. Of the remaining community college students, nearly the same percentage (40\%) are between 22 and 39, and $16 \%$ are 40 or more years old. More women and minorities seek postsecondary education by attending community colleges than in the past. Most community college students are female (56\%) and more than one third (36\%) of community college students are non-white. The diversity of community college students extends to their enrollment and familial status. Traditionally, students have enrolled in college on a full-time basis and have few responsibilities beyond college. This is not so for community college students. More than half $(60 \%)$ of community college students enroll on a part-time basis and $16 \%$ of them are single parents (Boggs, 2011). More than a third of community college students enrolled part-time are fiscally responsible for another person (Baime \& Mullin, 2011). In addition, most community college students are employed full or part-time regardless of their parents' educational levels (Nomi, 2005).

Often, parental college education degree attainment is related to higher family income brackets. Horn and Berger (2004) found the likelihood of a student having at least one parent with a Bachelor's degree increased by 3\% from 1989 to 1995 . While research indicated that college students in general were more likely to have at least one parent with a Bachelor's degree, there were still many students from low-income families attending college. Corrigan (2003) found two-thirds of low-income students come from families where neither parent went to college. Terenzini et al. (1996) and McConnell (2000) reported that FGCS were more likely to come from low-income families. Horn and Berger (2004) reported the percentage of low-income dependent students increased to $16 \%$ and the percentage of low-income independent students rose to $47 \%$ of the student population between 1989 and 1995. Corrigan (2003) explained one- 
third of low-income students and three-fourths of independent students support dependents. He elaborated that among students who work, low-income students work more hours on average and $23 \%$ of low-income dependents work full-time and 30\% of low-income independent students supporting dependents work full-time. Low-income students are four times more likely to attend two-year and less-than-two-year for-profit institutions, less than 10\% of low-income independent students with dependents attend Bachelor's degree granting institutions, 45\% of low-income dependent students attend community college, and only $38 \%$ of middle- and upper-income students attend community college (Corrigan, 2003).

Another group of students differing from traditional undergraduates is first-generation college students (FGCS). Students who are the first in their family to attend college face unique challenges in entering college as well in earning a degree (Hudley et al., 2009). They are less likely to attend college when their parents have not (Choy, 2001). While nearly all high school students whose parents attended college attend college also, only $59 \%$ of students whose parents never attended college enroll in a four-year institution within two years of graduation from high school. Even after they enter college, almost a third of these students leave during their first three years (Choy, 2001). The more common route in pursuing a college education for FGCS is attending a community college. FGCS are more than twice as likely to attend two year institutions (Ishitani, 2005). More than $40 \%$ of the parents of students at two-year institutions have a high school or lower educational level (Nomi, 2005; Snyder, 1999) and of the FGCS at community colleges, $67 \%$ are female (Nomi, 2005). FGCS tend to enroll at institutions one fourth less academically selective than those whose parents had a high level of postsecondary education (Pascarella et al., 2004).

Research has identified a number of characteristics common to many FGCS but which set 
them apart from many other students. FGCS are more likely to be women, older than traditional age, have dependent children, and be employed full-time (Boggs, 2011; Terenzini et al, 1996). These older students generally delay entry into postsecondary education and enroll as part-time students (Nomi, 2005, Terenzini et al., 1996). Copenhaver-Bailey (2005) reported FGCS differ from traditional colleges students by age, ethnicity, socio-economic status, dependent status, time needed for degree completion, work habits, institutional satisfaction, and college experiences. FGCS tend to take fewer credit hours each term and face more financial challenges and family responsibilities than other students (Nomi, 2005). In this same study, more than a third (35\%) of FGCS at community colleges referred to family responsibilities as a moderate or major problem while attending college. Nomi (2005) further explained half of the FGCS at community colleges enroll in three or less classes each term. Although FGCS at community colleges have a higher annual income than their non-FGCS counterparts, they are also more likely to work full-time and be the primary wage earner in their household. Even with working full-time, their income typically averages only $\$ 11,000$ per year (Nomi, 2005).

Although the types of institutions FGCS attend differ from that of traditional students, there are few differences in FGCS' satisfaction with their college experience. Overall, community college students report their college experiences have contributed to their academic and nonacademic development. However, FGCS report greater satisfaction (Nomi, 2005). Duggan (2001) reported mixed satisfaction levels with FGCS being slightly more satisfied with the campus climate but slightly less satisfied with their instructors' ability to teach. FGCS reported similar satisfaction as traditional students with the cost of attending college, intellectual development, or prestige of the school they attend (Duggan, 2001).

As a result of being first in their families to attend college, FGCS tend to have less 
experience with and fewer resources for information on the social and academic demands of higher education (Corrigan, 2003). They also have little mentoring and role modeling, little knowledge of college experiences, little support for attending college, feelings of guilt for leaving their family, low self-confidence in their abilities, and live with high family expectations of success as a result of being the only family member to attend college (Copenhaver-Bailey, 2005).

\section{Goals and Intentions}

Students' academic goals and preparation have also changed. Overall, undergraduate students in 1995 expected to earn higher degrees than students in 1989. Ten percent more of the students in 1995 expected to complete an advanced graduate or professional degree while the percentage of students expecting to earn a Bachelor's degree dropped $4 \%$ and the percentage expecting to earn a credential less than a Bachelor's degree dropped 5\% (Horn \& Berger, 2004). In a national community college study, FGCS were significantly less likely than their peers to aspire to transfer to a four-year college or university and were more likely to aspire to earn an Associate's degree or certificate and improve job skills (McClenney \& Green, 2005). Forty-six percent of FGCS attending community colleges do so to take courses to enhance specific job skills (Nomi, 2005). More than $85 \%$ of FGCS at community colleges refer to having a steady, secure job as a very important accomplishment (Nomi, 2005).

Students face many decisions as they seek an education. One of the first they face is what institution to attend. Students must choose between four-year public or private institutions, twoyear or less than two-year public or private institutions, and non-profit or for-profit institutions. Wild and Ebbers (2002) reported $44 \%$ of all United States undergraduates and $46 \%$ to $47 \%$ of first-time freshmen were enrolled in community colleges. At community colleges, $58 \%$ of the 
students indicated a goal of transferring to a four-year college or university (Community College Survey of Student Engagement, 2002). However, in Nomi's (2005) study, only 35\% of FGCS at community colleges intend to transfer to a four-year institution.

Low-income students are a special concern to administrators because they make different educational decisions than do their middle-and upper-income counterparts. King (2003) found that location, selectivity, and curricular offerings played a large role in student choice of institution. Low-income students are more likely to be found at some institutions and have different attendance patterns at those institutions. As compared to more than half of the middleand upper-income freshmen less than one-third (30\%) of low-income freshmen in 1995 were at four-year institutions (King, 2003). In fact, low-income students are significantly more likely to select two-year and less than two-year for-profit institutions along with public community and vocational colleges (Corrigan, 2003; King, 2003). Only 42\% of low-income students are likely to study full-time, full-year as compared to $64 \%$ of the middle- and upper-income students but are no more likely to choose institutions based upon price than are middle- and upper-income students (King, 2003).

FGCS also tend to be significantly more limited than traditional students in the types of institutions they attend and the kinds of experiences they have during college (Pascarella et al., 2004). FGCS are less likely than traditional students to attend college at least 150 miles from home and to live in campus housing (Duggan, 2001). When non-FGCS attend community colleges, they do so for the purpose of transferring to a four-year college. In contrast, FGCS enroll in community college to improve their job skills and to obtain an associate's degree (Nomi, 2005). The experiences of FGCS while attending college differ from those of other students. Wild and Ebbers (2002) reported that overall, FGCS are at a disadvantage in access to 
postsecondary education. This disadvantage persists even when other factors such as educational expectations, academic preparation, support from family and schools, and family income are controlled. Pascarella et al. (2004) described FGCS as at greater risk of being academically, socially, and economically left behind. However, even though they face greater economic and social disadvantages, FGCS at community colleges express greater satisfaction with their academic and non-academic college experiences than do their non-FGCS peers (Nomi, 2005).

\section{Financial Knowledge and Resources}

Many students are concerned about financing their education as the costs associated with attending college increase substantially. Between 1979 and 1994, charges for tuition, room, and board rose $48 \%$ at public four-year and $71 \%$ at private four-year colleges (National Center for Educational Statistics, 1999). Horn and Berger (2004) reported that nationally, tuition increased between 20\% and 40\% between 1989 and 1995 alone. By 2010, the charges for tuition, room, and board rose to more than $\$ 20,000$ at public four-year institutions and nearly $\$ 40,000$ at private nonprofit four-year institutions (Aud et al., 2012). While parents' income and savings are reported as major sources of funds for college-related expenses for non-FGCS, only $14 \%$ of FGCS report their parents' income and savings are a major source of funds for college related expenses (Nomi, 2005). As a result, more than half (55\%) of FGCS rely on financial aid as a major source of funding for college (Nomi, 2005). The arduous nature of navigating the financial aid system, the need to accept loans as a part of the financial aid package, and basic knowledge about financial aid programs and the federal aid system provide additional challenges for a family with a lower socioeconomic status (Horn \& Berger, 2004).

Originally, financial aid was intended to help low-income students earn a college education by providing grants (Cofer \& Somers, 2000). However, the focus of financial aid has 
shifted considerably since its origins. During the 1960s and 1970s, Congress changed the traditional direction of student aid from providing money to institutions through grants based on students' financial needs to loans directly to students without regard for students' financial needs (King, 2003). Education Amendments in 1972 expanded student aid through the Pell and Stafford Programs (King, 2003). The focus of student aid continued to change with the Middle Income Student Assistance Act (MISSA) of 1978 which led to student aid programs using guaranteed loans as the primary direct aid funding mechanism (King, 2003). Further education amendments in 1980 added the Parent Loans for Undergraduate Students (PLUS) program for non-need based low-interest loans to parents to support their undergraduate dependent students (King, 2003). In 1986, the focus of financial aid shifted slightly again when Congress reinstated financial restrictions for Guaranteed Student Loan (GSL) applicants for families earning above $\$ 30,000$ (Alexander, 2002). Over the years, this system of student-oriented grants and loans began to be made freely available to institutions in both the private and public sector instead of limiting their availability to only public institutions (Alexander, 2002).

One component used to determine the amount of aid students receive is institutional cost. King (2003) explained students at potentially more expensive private colleges receive a higher rate of aid than those at less expensive public institutions. Thus, the likelihood of qualifying for student aid is greatest at high-cost proprietary and private "non-profit" institutions while students attending low-cost public community colleges are the least likely to receive federal and state grant and loan aid. Students attending private institutions received over $45 \%$ of all grant monies even though they only represented $24 \%$ of the full-time student population. Nationally, by 1999 , state funding for need-based and merit-based direct student aid combined exceeded $10 \%$ of all state appropriations to higher education (King, 2003). By 2010 almost 3.5 million community 
college students received a Pell Grant (Baime \& Mullin, 2011).

Grants through student financial aid programs reduce the average cost to low-income students by $45 \%$ (King, 2003). Despite this reduction, the remaining costs still represent a significant portion of the entire family income for low-income students at $42 \%$ of the family income for dependent students and $61 \%$ of the family income for independent students (King, 2003). In 2009, almost $80 \%$ of community college students who received the Pell Grant had family incomes below 150\% of the poverty level (Baime \& Mullin, 2011). King's (2003) report elaborated that for low-income students, relying on loans is a less popular choice than attending part-time or living at home. FGCS are among the groups of students who are less likely to take advantage of loans to pay for their education (England-Siegerdt, 2011). Although many lowincome students avoid loans as freshmen, those who persist to a Bachelor's degree are more likely to borrow and accrue more debt than their middle- and upper-income peers. Only $45 \%$ of community college students report their college provides the financial support they need to afford their education and only 44\% report their parents provide support (CCSSE, 2002). In addition, 55\% of these students reported they do not receive grants or scholarships (CCSSE, 2002) and 75\% reported they did not have student loans (Baime \& Mullin, 2011; CCSSE, 2002).

While there were increases in financial aid along with the increases in tuition, Horn and Berger (2004) reported the amount of students who borrowed money to help pay for their education increased from one fifth to nearly one third of first year students. As students continue their educations, more of them depend on loans to help meet their financial needs. Nearly one half of all students end their education with loan debt (Horn \& Berger, 2004). In 2002, King reported loans as the most employed student aid program.

As a result of the increased expense of seeking an education, students must make difficult 
decisions. King (2003) recognized some of these decisions are based on inadequate information about the possible consequences and available alternatives. He explained students often make decisions that are not in their best academic interest but are instead intended to contain the immediate price of attending college. These choices are often made to support a particular lifestyle such as living off campus, carrying a credit card balance, or accommodating career and family obligations. The most common strategies low-income students use to reduce cost is to apply for aid, to work, and to attend college part-time. Attending full-time may result in higher annual costs but can also shorten the length of time needed to complete a degree which results in lower total college expenses. In addition, research has consistently shown students who attend college full-time are more likely to complete a degree than those who attend part-time (King, 2003).

Van T. Bui (2002) found First Generation College Students (FGCS) are even more concerned about financial aid than are other students. Almost half $(47 \%)$ of the FGCS at community colleges in Nomi's (2005) study reported finances were a moderate or major problem while attending college. Traditional students attend college full-time and work few, if any, hours as they earn degrees. This is often not true of FGCS. They are often reluctant to accrue debt in order to finance their education. Cofer and Somers (2000) found accumulated debt, even at low levels, was significantly and negatively associated with the persistence of FGCS. Once they begin their education, FGCS completed fewer credit hours during the first three years of study and worked more hours per week than did the group of students whose parents had higher educational levels (Pascarella et al., 2004). This applies to students at multiple types of institutions. Over half of community college students work more than 20 hours per week (Baime \& Mullin, 2011). Nearly half of FGCS at community colleges enroll in three or fewer courses in 
contrast to the $40 \%$ of non-FGCS (Nomi, 2005). No doubt related to this altered attendance pattern, Terenzini et al. (1996) found FGCS expected to need extra time to complete a degree. As they attended college, Duggan (2001), reported FGCS were more likely to be working offcampus than were second-generation college students. One of the most critical aspects of helping community colleges meet their completion goals will be their ability to ensure students are able to access financial aid. For every $\$ 1,000$ increase in student loans, the chance of students enrolling in college increases by 3.8\% (England-Siegerdt, 2011).

\section{Tinto's Model of Student Departure}

Braxton, Hirschy, and McClendon (2004) explained Tinto developed a theory as to why students depart from college in 1975. Tinto's model outlined how the individual characteristics (such as family background or pre-college schooling experiences) that students possess as they enter college influence their initial commitments to institutions, their goals for graduation, and their departure decisions (Braxton et al., 2004). Their individual entry characteristics affect their integration into both the academic and social systems of an institution. The academic system focuses almost entirely upon the formal education of students. Academic integration occurs when students meet explicit standards set by the institutions and they identify with the beliefs, values, and norms inherent in the academic system (Braxton et al., 2004). Social integration occurs when students perceive their values, attitudes and beliefs are consistent with the norms of the social communities found within a college or university. Tinto's theory further explained the degree to which students are integrated into the academic and social systems influence their commitments to remain at a particular institution and to pursue their goals of graduation.

In 1993, Tinto revised his model by incorporating two additional components. First, the influence of external communities (including family and work) was added. Second, students' 
financial resources were included as part of the entering characteristics with which students enter college. The rest of this model remained intact and continued to emphasize that some degree of academic and social integration must exist for students to persist (Tinto, 1993).

In general, Tinto's model has found wide-spread support within the higher education community. It has reached paradigmatic status because there is considerable agreement among scholars of student departure regarding the potential validity of Tinto's theory. There are more than 775 citations including research on Tinto's model (Braxton et al., 2004). It is beyond the scope of this literature review to examine the hundreds of research studies based on Tinto's model. Some research studies will be highlighted that examine persistence variables in Tinto's proposed model that are especially noteworthy for the FGCS population.

Braxton et al. (2004) revised Tinto's original model and outlined various influences of social integration. These influences include: commitment of the institution to student welfare; the extent to which a student believes a subgroup of students within the community shares his or her values, beliefs, and goals; institutional integrity; student proactive social adjustment; student psychosocial engagement; and student ability to pay the costs of attending his or her chosen institution. Braxton et al. (2004) examined thirteen propositions based on Tinto's original theory. Their study is limited in that it did not focus on the 1993 version of Tinto's framework. However, their study found modest support for academic integration influencing student departure and commitment to an institution. Another limitation is that the authors could only focus on the variables that were empirically investigated within research studies published in refereed journals. The five highly supported propositions included the following:

1. The characteristics students have at college entry affect their initial level of commitment to the institution; 
2. The more students are socially integrated into the college, the greater their ensuing level of commitment to the institution;

3. The initial amount of institutional commitment students have affects their continued level of institutional commitment;

4. The initial amount of commitment students have to the goal of graduation from college influences their continued level of commitment to the goal of college graduation; and

5. The greater the students level of continued commitment to the institution, the greater the likelihood of students persisting in college.

In addition, when focusing on two-year colleges, only one of the thirteen propositions described by Braxton et al. (2004) was actually researched. They found student entry characteristics affected the likelihood of students' persistence in college. Several studies provided empirical affirmation of their findings. The other twelve propositions were either not tested or resulted in indeterminate support due in part to a lack of studies (Braxton et al., 2004). They concluded that future testing of Tinto's revised theory should take place in two-year and four-year commuter institutions.

The philosophical framework of this dissertation research study is based upon Tinto's model of student departure (Figure 1). Within this framework, there are two basic stages in student integration into college. The first stage occurs before students enter college. During this stage, students begin to plan for their futures. Their academic skills, financial resources, and support interact to help them develop their goals for the future, commitments to those goals, and their intentions of how to meet those goals. Those goals, commitments, and intentions interact with any commitments they might have to help determine if students will attend college. Once 


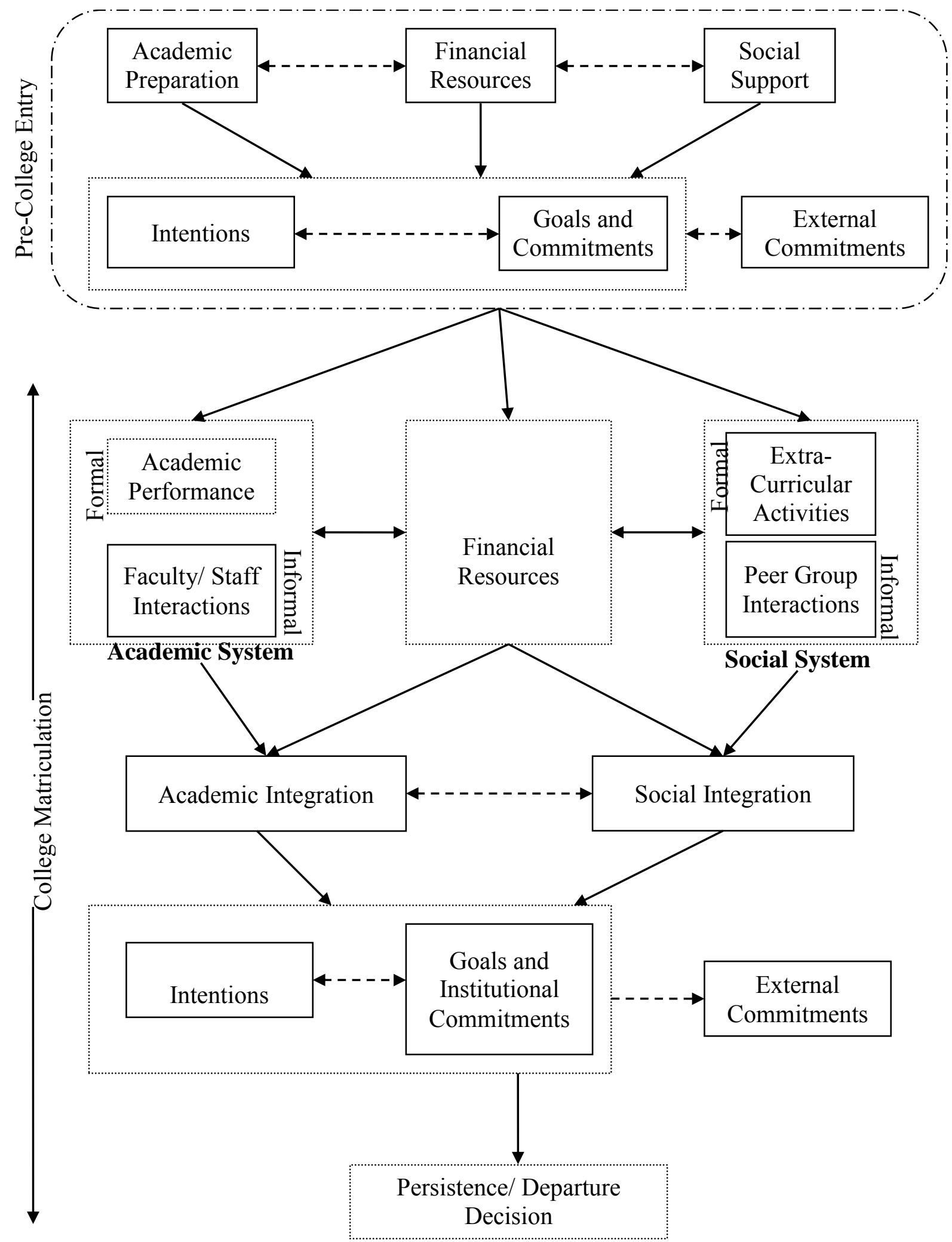

Figure 1. Conceptual framework based upon Tinto's Model of Student Departure. 
they enter college, the academic and social systems and the students' financial resources interact with their personal characteristics to affect the degree to which students are integrated into the institution. Once they enter college, the academic and social systems of the college and the students' financial resources interact with their personal characteristics to affect the degree to which students are integrated into the institution. Students' academic and social integration interact to influence whether or not their goals change and to directly affect whether students persist or depart from college.

\section{Academic Integration}

As indicated by Tinto (1993), students' persistence in college depends in part upon their integration into the academic environment of their institutions. This integration is influenced by their pre-college schooling and other pre-college attributes. During this pre-college stage, students develop the academic skills, social support, and financial resources needed to successfully navigate the college environment. All students have some degree of academic skills, social support, and financial resources at their disposal. These resources interact with each other and in turn, influence students' goals. Their goals affect their initiation into college. Nora, Attinasi, and Matonak (1990) found pre-college schooling had a positive correlation with retention. Students taking a rigorous high school curriculum were more likely to persist into their second year than those taking a less rigorous curriculum (Duggan, 2001). Given that almost half of FGCS place in the bottom quartile of college applicants (Berkner \& Choy, 2008) their likelihood of persisting into their second year is lower.

As students enter college they begin integrating into their new institution and separating from their previous school and experiences. Elkins, Braxton, and James (2000) studied Tinto's separation stage and its influence on first semester college student persistence. Tinto (1993) 
asserted that students enter a separation stage when they initially begin college that is most influenced by pre-college and external communities. This separation is the time when students disassociate from their previous communities and can offer an explanation for why some students depart within the first semester. Elkins et al. (2000) found that gender, race, parent income, and high school academic achievement were statistically positive influences on support for college attendance. As parent income increases, the support a student receives also rises. Students with records of high achievement also get greater support. Another major finding was that the greater a student's initial level of institutional commitment the more likely a student was to perceive the need to reject the attitudes and values of past communities. Students who receive substantial support for college attendance or who perceive the need to reject past communities' attitudes and values are less likely to depart from college.

Bers and Smith (1991) explored the influence of student intent and academic and social integration on community college student persistence. The study found that academic and social integration was connected to student persistence. Although social integration played a larger role in persistence, both academic and social integration distinguished students who persisted from those who did not (Bers \& Smith, 1991). They also found students' educational goals and intent to reenroll, pre-college characteristics, and employment status were more strongly correlated to student persistence than were social and academic integration once students attended college. Research has indicated first generation college students (FGCS) often do not consider college as an option and thus do not take an appropriate curriculum to prepare them for collegiate study. For many FGCS, the possibility of receiving higher education is a foreign concept. Fallon (1997) found FGCS often come from high schools with poor academic programs, have not been exposed to college preparation curriculum, and have not been encouraged to take part in the 
courses and guidance activities which would help them compete for college admission. FGCS reported fewer high school grades of A's than did second generation college students (Duggan, 2001). In a national community college study, FGCS were significantly less likely than their peers to aspire to transfer to a four-year college or university and were more likely to aspire to earn an Associate degree or certificate and improve job skills (McClenney \& Green, 2005).

FGCS tended to be less academically prepared for college level work than other students. Van T. Bui (2002) reported FGCS themselves felt less prepared for college in comparison to other students. This poor academic preparation is further demonstrated through entrance exam scores and the need for remedial coursework. Terenzini et al. (1996) found FGCS had lower critical thinking skills than traditional students and they scored lower than traditional students in pre-college reading and math skills. Despite FGCS having lower pre-college skill levels, no differences were reported between FGCS and traditional students in mathematical or critical thinking abilities during their first year of college (Terenzini et al., 1996). Although the selfreported grade point averages at the end of their first year were not significantly different for first generation and second generation students, second generation students made greater gains in reading comprehension during their first year than did FGCS (Duggan, 2001). Even more revealing is the report by Terenzini et al. (1996) that while FGCS derived greater benefits in reading skills by studying more hours than did traditional students, they reported fewer hours per week studying. In contrast to reports FGCS are less academically prepared, few FGCS cited academic failure as their reason for leaving. Rather, they cited the stress of conflicting demands such as family, job, and finances (Fallon, 1997). This preparation or lack of preparation for college level work influences students' success in college.

Tinto also stressed that students' academic experiences while in college also influence 
their persistence and completion of their degrees. Research indicated $25 \%$ to $40 \%$ of community college students took remedial courses (Horn \& Berger, 2004; Kazis \& Liebowitz, 2003). Four percent more students in 1995 took remedial classes than did those in 1989 and of these students, at least one quarter fail their remedial courses (Kazis \& Liebowitz, 2003). In the 2007-08 year, $42 \%$ of first year students at public two-year colleges took at least one remedial class (Aud et al.). Duggan (2001) reported FGCS were more likely to have taken at least one remedial course than second generation college students. This trend is especially disheartening with the realization that the more remedial courses a student needs to take, the less likely he or she is to earn a degree (Kazis \& Liebowitz, 2003; McClenney \& Green, 2005).

Many institutions focus on first year students to provide them with connections and contacts at the institution. Upper-level students often have formed connections through participation in their academic majors and through leadership roles in the campus community. However, sophomores may be caught between these two levels where they do not have the focused attention of the programs offered to them as first-year students but still have not made connections in their majors or leadership roles (Graunke \& Woosley, 2005). While institutional commitment is not a significant predictor of their success or grades, research has indicated sophomores are impacted by the extent to which they were satisfied with their opportunities to interact with faculty and the extent to which they believed faculty were concerned with their academic success (Graunke \& Woosley, 2005). Overall, Graunke and Woosley found students' commitment to their academic major and their satisfaction with faculty were significant predictors of sophomore academic success.

\section{Social Integration}

Social integration is a very important dimension in Tinto's (1993) model. Many research 
studies have focused on the social integration of college students. Finding adequate social support is often identified as a key component for student success in higher education. Research has shown that students who are socially integrated are more likely to persist (Joseph, 1995). Additionally, some students do not know how to negotiate the bureaucracy of higher education and must obtain support for their educational endeavors.

First generation students must seek assistance from adults other than parents to navigate entry into college. While only a third of non-FGCS receive assistance from high school staff in completing financial aid applications, more than half of FGCS do (Choy, 2001). In addition, first-generation college students (FGCS) may miss out on informal exposure to the higher education environment others obtain by listening to significant adults talking about college experiences (Fallon, 1997). Some FGCS reported feeling overwhelmed with the unfamiliar environment of college and were challenged to find places to study, meet friends, or seek support (Richardson \& Skinner, 1992). Cofer and Somers (2000) found the more differences there were between FGCS' home environments and that of their campus environments the less likely students were to persist in college unless they were engaged in the life of the campus through living on campus, doing well in specific courses, finding support from a faculty member, or finding a social niche. Because FGCS are more likely to see the purpose of college as a means to a good job, they often are less committed to the role of student and are less involved in campus life (Fallon, 1997).

Zwerling (1992) found first-generation adult students typically received more emotional support for their academic endeavors than did their younger classmates; however, they were even more likely to have conflicting obligations. The additional demands they faced cause FGCS to experience conflicting loyalties, making it difficult for them to give a college education their full 
attention (Fallon, 1997). Richardson and Skinner (1992) found that FGCS who attended community colleges typically attended part-time and were more likely than their classmates to have significant work and family responsibilities. Additional research has documented that FGCS at community colleges spend significantly more time caring for their dependents than their peers (McClenney \& Green, 2005).

Richardson and Skinner (1992) identified peer support as an important factor in minority students' academic achievement. In addition, this same report explained support groups were more likely to develop among students from college-educated families. Research has indicated FGCS were less likely to report receiving encouragement from friends to continue their enrollment (Terenzini et al., 1996). Pascarella et al. (2004) found in addition to not living in campus housing, FGCS also reported lower levels of extracurricular involvement and interaction with peers in non-course contexts. Despite their lower level of extracurricular involvement, FGCS often derived greater benefits from involvement and peer interaction than did other students with one exception. FGCS who were involved in volunteer work, employment, and participation in intercollegiate athletics were less likely to persist. Students who persist in general more often reported their best friends were currently enrolled in college than do students who leave (Pascarella et al., 2004).

Social integration of students can prove to be a challenge especially at community colleges. Often, community college students struggle to feel comfortable on campus and to feel as if they know their way around campus (Tinto \& Love, 1995). Community colleges have a limited window of opportunity to engage students. Most student-faculty interaction takes place in the classroom and many students do not participate in college sponsored extracurricular activities (CCSSE, 2002). The 2005 Community College Survey of Student Engagement found $60 \%$ of the 
community college students were part-time students and $57 \%$ of these students work more than 20 hours per week (CCSSE, 2005). These two characteristics also make it difficult for students to be socially engaged with college activities.

\section{Departure/Persistence Decision}

Students enter college with a wide variety of goals and aspirations. However, these goals often change. Bers and Smith (1991) reported a correlation between student goals and persistence. In their study, students taking courses in pursuit of a degree or to transfer were more likely to persist than those taking courses for job-related reasons or for personal enrichment or exploration (Bers \& Smith, 1991). FGCS have been reported to have lower degree aspirations (Terenzini et al., 1996) and those FGCS who aspire to a Bachelor's degree are twice as likely to persist as are FGCS who aspire to more advanced degrees (Cofer \& Somers, 2000).

Horn and Berger (2004) reported a small increase in the percentage of students who began their college career at four-year institutions but who five years later were enrolled in programs lasting no more than two years at institutions such as community colleges. This same study reported the percentage of students who earned a vocational certificate declined while the percentage of students continuing enrollment at a four-year institution increased (Horn \& Berger, 2004). The percentage of community college students who complete an Associate's degree or even a certificate program is low; fewer than half of these students earn their degree or are still enrolled after five years (Kazis \& Liebowitz, 2003). By 2003, research indicated the three-year graduation rates at two-year institutions reached a twenty year low of 34.3\% (McClanahan, 2004). American College Testing, Incorporated (ACT) (1998b) reported a 4.7\% decrease in the graduation rates of public Associates degree granting institutions with open admissions and a 1.3\% decrease at private Associate's degree granting institutions between 1983 and 1997. 
The persistence rates for each type of institution vary and institutions are concerned about the persistence and retention of their students. Researchers have examined which students are more likely to persist and earn a degree. Persistence has been linked to student demographics, student work habits, student status, student aspirations, and student personality traits as well as students' academic experiences and financing. Cofer and Somers (2000) found FGCS who declared their race as "other minority" were more likely to persist than were white FGCS.

Corrigan (2003) identified seven factors associated with a reduced likelihood of student persistence: (1) independent status; (2) attending college part-time; (3) working full-time while enrolled; (4) having dependents; (5) being a single parent; (6) delaying entry into college; and (7) not having a traditional high school diploma. Cofer and Somers (2000) reported after their first year of college, residential students and FGCS were more likely to persist than those who lived off campus.

These risk factors are increasingly common among college bound students (CCSSE, 2002; Corrigan, 2003; Horn \& Berger, 2004). Nearly two-thirds of community college students exhibit two to four of these risk factors (CCSSE, 2002). Cofer and Somers (2000) reported fulltime students were more likely to persist than were part-time students. This is especially concerning to community college administrators given $47 \%$ of community college students enroll on a part-time basis (Horn \& Berger, 2004).

Research has also discovered students' work experiences affect their persistence rates. Bers and Smith (1991) found the more hours students worked, the less likely they were to persist. In 1982, Billson and Terry reported twice the numbers of students who leave had worked fulltime in the term prior to leaving than those who stayed. A similar pattern was observed by Cofer and Somers (2000) who reported students attending college while working full-time were less 
likely to persist than other students. Corrigan (2003) also noted those students who work fulltime are less likely to obtain a degree or still be enrolled. These persistence rates are especially significant when taken into consideration along with Culp's (2005) data indicating 80\% of community college students work full- or part-time in addition to their family responsibilities.

The percentage of college students who are single parents has increased (Horn \& Berger, 2004). Horn and Berger (2004) also reported the percentage of students in public two-year institutions who graduated from high school with a regular high school diploma decreased between 1989 and 1995. Corrigan (2003) found 22\% of the students from low-income families with dependents have earned an alternative high school credential.

Horn and Berger (2004) found almost half of the students they examined exhibited at least one of these factors when they enrolled in college. The degree completion rate for students with one or more risk factors decreased between 1989 and 1990. However, the likelihood of their remaining enrolled increased over time (Horn \& Berger, 2004). By their second year, FGCS are eight times more likely to drop out of school and by their third year are four times as likely to drop out (Ishitani, 2005). In contrast, the CCSSE (2002) report indicates students who exhibit more risk factors are more likely to participate in study-skills classes, college orientation and success courses, and organized learning communities.

Research has also linked individual traits (such as intelligence, work drive, and personality traits) to student persistence. Ridgell and Lounsbury (2004) reported general intelligence significantly predicted course grades and overall grade point average. This same study found work drive to also be a good general predictor of performance which could be used in addition to intelligence and five main personality traits. Personality traits that were related to academic performance were emotional stability, extraversion, agreeableness, conscientiousness, 
and openness to experience. However, the degree of relationship between these traits and academic success depended at least in part on other factors such as students' year in school and the type of criterion used to represent performance (Ridgell \& Lounsbury, 2004). They elaborated that one trait, emotional stability, was significantly correlated with a single course grade, but not with overall grade point average. The effect of these various factors on students differs depending on their educational level.

Student persistence is also impacted by financial concerns. Specifically for low-income students, those who borrow and work part-time perform better than those who work part-time but do not borrow (King, 2003). As the cost of tuition increases, the persistence rate of FGCS decreases. Cofer and Somers (2000) found for every $\$ 1,000$ increase in aid, there was an increase in persistence. As previously indicated, the most prevalent form of student aid is loans. King (2003) reported that students with loans and who worked part-time had the lowest dropout rate.

\section{Retention Efforts}

As community colleges are held responsible for their students' successes, there is an increased focus on success data. In 1995, slightly more than one third of college students earned certificate, associate, or bachelor's degree within six years of graduating high school (Boggs, 2011). However, these numbers may not paint an accurate picture of community college student success. Although students may not have completed degrees, they may have met other personal or professional goals.

The standards for determining postsecondary completion rates are established by the Organization for Economic Co-operation and Development (OECD). These standards do not consider students who enter college do not enroll to obtain an associate degree or transfer to a four-year college, high school students who participate in dual enrollment programs, four-year 
college students who take classes at community colleges, or students who enroll in classes to obtain specific skills (Boggs, 2011 and Mullin, 2010). As community colleges are held accountable to meet the OCED standards, they must focus on either increasing completion rates using traditional criteria or helping people in the community return to work faster by earning certificates and credentials that are not counted as success according to traditional criteria (Mullin, 2010). In spite of not being considered completion, there is an increased demand for short-term and work related certificates. Between 1997 and 2007, there was almost a 60\% increase in demand for these programs (Mullin, 2010). The economic forecast projects of the 10 fastest growing occupations, eight will require less than a bachelor's degree and six will require less than an associate's degree.

There are a variety of institutional practices and procedures designed to enhance student retention. Student retention is defined as students continuing at an institution and making academic progress toward successfully completing a degree or program. However, when reviewing graduation rates, researchers must remain cognizant of institutions' purposes. Community colleges serve a wide variety of students who can be well-prepared or poorly prepared students, the academically gifted and the academically at-risk. Community colleges are actively involved in training the American workforce (Dougherty, 2001). Dougherty (2001) explained that students with one-year certifications earn significantly higher wages than those with a high school education. These certification programs for job training do not result in an Associate's degree but do result in certification which will be beneficial in the job market. In addition, senior citizens enroll and take a few courses as well as high school students (Neutzling, 2003). Culp (2005) explained community colleges are viewed as opportunities for students who are not prepared or are underrepresented and those who need a second chance or new start. 
Neutzling (2003) described the intent of community colleges as being to serve students and to enhance the educational opportunities in the communities they support. As a result of this diverse student population, community colleges are less homogeneous than many other institutions (Wild \& Ebbers, 2002). In the CCSSE (2005) report, 41\% of the students identified obtaining job related skills as their primary goal in attending college. In this same report, $47 \%$ of the students named transfer to a four-year college or university as a likely or very likely reason they may not return to their current institution (CCSSE, 2005).

Although the roles of community colleges are vastly different from those of other institution types, the same criteria are used to determine graduation and retention data (Neutzling, 2003). The significance of data about persistence and retention at community colleges must be assessed carefully. Some have asserted that retention rates should be linked to individual students' goals. For example, some community college students may enroll to take three or four specific courses they need in order to transfer to another college.

Similar to other types of institutions, community colleges need to address the retention of their students. ACT (1998a) reported a slight but steady increase in the rate of students at twoyear institutions not returning for their second year. However, in 2011 the National Center for Education Statistics (NCES) reported an overall increase in full and part-time students at twoyear colleges returning to college between 2006 and 2010. In order to benefit the community as well as the individuals in the community, colleges must work with educators in primary and secondary school systems and create partnerships with businesses and civic groups to continue serving underrepresented groups (Culp, 2005). Using these connections, college personnel must help identify and intervene with students who are known to be most at risk: those with two or more developmental courses, have not declared a major, believe they will fail, enroll in on-line 
courses without the skills or motivation to succeed, who are on probation, or who face suspension or dismissal (Culp, 2005).

Many administrators are concerned about the retention and persistence of students. As a result, institutions across the country are implementing strategies to increase student retention that include: developing criteria to indicate which students are not persisting; creating learning communities and cohort groups; and developing directed retention, tutoring, and supplemental instruction programs (Damashek, 2003). Bailey and Alfonso (2005) grouped retention strategies into four major categories: (1) student services; (2) learning communities; (3) developmental education and supplemental instruction; and (4) college-wide reform.

The first of Bailey and Alfonso's (2005) categories, student services based retention programs, includes advising, counseling, mentoring, and orientation programs. Research on counseling and other student services suggest they can play an important role in retention and graduation. However, there are limitations to the available research. One weakness consists of the student population studied. Most of the research has been limited to four-year institutions. While there are encouraging results on community colleges, much of the material that has been published does not permit a judgment about the validity of its conclusions (Bailey \& Alfonso, 2005). The studies that have been conducted indicate counseling increases the retention of students who are identified as highly likely to drop out. Students who used support services also increased their grade point averages and increased their retention. The effects of student support services appeared to increase with the amount of exposure to the program. Of the student services oriented programs, the most effective format appears to be first-year seminars which orient students to the institution and teach them important survival skills. Graduation rates for community college students who participate in orientation courses are 72 times higher than for 
those students who did not participate in the courses (Duggan \& Williams, 2011).

Student services oriented programs are typically based upon particular theoretical frameworks. One common framework for student services based retention plans incorporates an intrusive program model. An intrusive program model assumes that although students who are failing need help, they frequently will not seek it out on their own or accept it on a voluntary basis and must be coerced into accepting the assistance (Damashek, 2003). A comprehensive intrusive approach is comprised of a variety of components. Often the program begins between semesters. Students attend an orientation workshop to gain a better understanding of their class standing, how serious their deficiencies are, and how grade point average is computed. Another component is the requirement for students to meet with academic advisors to review their transcripts, discuss the causes and seriousness of their difficulties, and to devise a plan to resume and maintain good academic standing. Students must continue to see their advisors on a regular basis to ensure they are progressing satisfactorily. Advisors conduct mid-term grade checks where faculty evaluate students' progress and recommend areas for improvement. Advisors continue to assist students in selecting courses and in making other decisions based upon the students' progress. Occasionally, advisors intervene on behalf of the student in special circumstances involving academic departments and administrative offices and services. Often, this approach requires the students to sign a contract which makes them accountable for keeping regular appointments and following all program requirements. Throughout this program, advisors update students' files. Once students have achieved good academic standing, they leave the program (Damashek, 2003).

Another type of retention model following a student services approach is a directed program. Directed programs identify a specific group of students who are at risk of not 
persisting. This type of program offers a wide variety of services to a targeted group. A directed program provides outreach and recruitment services to solicit participants. After students are oriented to and registered in the program, their progress is monitored. Additional services which may be provided include basic skills instruction, child care, peer advising, financial aid grants and single-parenting support groups (Wild \& Ebbers, 2002).

A second category of retention program is that of learning communities. Learning communities are formed with specific groups of students who have shared curricular experiences instead of largely independent course experiences (Tinto \& Love, 1995). Tinto and Love's study indicated students in learning communities found social as well as academic support. Although all students in the study reported similar activity rates for in and out of class activities, members of the learning communities were more positive in their views of all aspects of the college. In this same study, members of learning communities were also more likely to continue in higher education than were other students. Wild and Ebbers (2002) reported students involved in learning communities and cohort groups indicated an increased desire to continue their education as a result of their experiences in learning communities. Students in Tinto and Love's (1995) study indicated the social connections they had with other students allowed them to study with and to help each other. These students also reported faculty in the learning communities provided support through complementary and coordinated courses, reinforcing the variety of experiences students brought to class, and holding meetings with the learning community team in order to better advise each student (Tinto \& Love, 1995). Of the different types of retention programs, learning communities appear to have the most support grounded in research, serving as the most influential theoretical perspectives used to study retention (Bailey \& Alfonso, 2005).

A third category of retention program involves developmental education and 
supplemental instruction. Developmental education is used to remediate academic deficiencies while supplemental instruction specifically focuses on classes that are difficult and provides the additional instruction necessary for students to master the material (Wild \& Ebbers, 2002). Developmental education assists student in developing the skills they will need to be successful in basic college level work. Supplemental instruction identifies specific courses that tend to have a high failure rate and provides academic guidance in addition to the regularly scheduled classroom. Institutions are developing innovative tutoring programs and supplemental instruction to further the objectives of remedial education and developmental education.

In the fourth category of retention efforts, institutions are looking toward college-wide reform. Community colleges must identify, evaluate, and modify their current practices (Levin, Cox, Cerven, \& Haberler, 2010). O'Banion (2011) asserts it is critical for community colleges to redesign their policies, programs, and how they use their personnel in order to help students persist in college. Kazis and Liebowitz (2003) explain institutional strategies include some form of intensive student supports in addition to curricular and program redesign. There are a wide variety of initiatives being used. Some programs are being shortened to accommodate working adults' schedules. Other institutions are breaking a single credential program into a series of modules providing intermittent credentials. Many institutions are experimenting with flexible scheduling to accommodate students' schedules. A few institutions have begun integrating developmental education into occupational or academic programs in order for students to have more immediate job skills improvement. Other institutions are strengthening the coordination and integration of non-credit developmental courses with for-credit courses (Kazis \& Liebowitz, 2003). O'Banion (2011) emphasizes the need for faculty, staff, and administrators to work together and all have the goal of helping students achieve their educational goals. 
As institutions are seeing more non-traditional and working adults on campus, many initiatives attempt to accommodate these students' needs. Kazis and Liebowitz (2003) cite three strategies that might enable colleges to be more effective in helping working adults obtain college credentials. One strategy is financial incentives for low-income students that address the high cost of college and compensate for their poor financial knowledge and preparation. A second strategy is providing support to help working adults cope with the academic, personal, and other problems that often lead to their leaving. A third strategy is redesigning programs and curricula to compensate for the severe time constraints, skill needs, and job advancement interests of working adults. Colleges and universities can build supportive educational communities that help FGCS address the challenges they face and help them reach their academic goals. Many research studies are dismissed by community college faculty and administrators as not representing their students. In order to make improvements to student outcomes and retention efforts, current programs and practices that are successful must be identified (Levin, Cox, Cerven, \& Haberler, 2010.)

\section{Summary}

Research described a number of benefits to increased educational levels for communities as well as for individuals. Boggs (2011) emphasized the importance of increasing the general level of education for the well-being of society and the economic competitiveness of a country. Communities benefit economically through increased tax revenues, greater productivity, increased consumption, increased workforce flexibility, and decreased reliance on government financial support. Communities also benefit from reduced crime rates, increased donations to charities, increased community service, improved quality of life, increased social unity and appreciation of diversity, and an improved ability to adjust to and use technology (McClanahan, 
2004). Economically, individuals benefit with higher salaries and benefits, employment, higher savings levels, improved working conditions, and personal and professional mobility. McClanahan (2004) explained from a social standpoint, more highly educated people benefit from improved health, improved quality of life for their offspring, better consumer decisionmaking, increased personal status, and more hobbies or leisure activities. Boggs (2011) explained higher lifetime earnings and a better quality of life are connected to educational achievement.

As community colleges seek to better understand their students and their students' needs, they must look beyond the research that is currently available. Bailey and Alfonso (2005) outlined a number of limitations to the existing research. Existing research tends to examine limited populations, use limited methods, and be presented to a limited audience. Many of the existing research studies have been limited to examining FGCS at four-year institutions. As a result, the findings from these studies may not apply to FGCS at other types of institutions, although improving in recent years, there is very little consistent data on community college students and the practices used by community colleges to improve retention. A second problem with current research is in the format of the studies. Those studies that have focused on community college students have also focused on specific programs and have had very few participants. Even if a study of a program indicates positive results, those results may not hold true for other students. A third problem is that community college studies are frequently unpublished or are available in formats which make it difficult to determine validity and reliability. In order to improve community college retention, studies must focus specifically on first generation community college students and investigate their specific experiences in higher education. 


\section{Definitions of Key Terms}

Academic challenges. The extent to which a student has the academic preparation, support, and abilities needed to achieve desired academic goals affects the level of academic difficulties the student experiences.

Academic goals. A student's academic goals consists of the type and level of education the student plans to reach. In addition, academic goals reflect the occupation the student hopes to have and the likelihood of the student attaining that future (Tinto, 1993).

Academic integration. A student is academically integrated into an institution when there is a match between the student's skills, interests, and needs with the academic characteristics demanded at a college. When students are academically integrated, there is an increased contact in and out of the classroom between the student and other members of the academic community where the student is likely to establish personal bonds and rewarding contacts with students, faculty, and staff (Tinto, 1993).

Academic support. Academic support is a systematic supply of resources so students can improve their academic skills and knowledge. In addition, students have contact the student considers rewarding with other students, faculty, and staff about intellectual and social issues (Tinto, 1993).

Authenticity. Authenticity focuses on the level to which researchers closely and honestly describe participants' experiences.

Commercially and nationally developed instruments. Palomba and Banta (1999) describe commercially and nationally developed instruments as those developed by an organization where the reliability and validity have been addressed for the instrument. 
Financial challenges. The extent to which a student has the financial resources available for and knowledge of the financial demands of seeking a college education influences the level of financial difficulties the student experiences.

First-generation college student. For the purposes of this study, students who are within the first generation of their immediate family to seek postsecondary education will be described as having first generation status.

Learning community. A learning community is a group of students who share a common educational experience.

Locally developed instruments. Palomba and Banta (1999) describe locally developed instruments as those developed by a person or group in order to match the local issues and concerns.

Low-income students. For the purposes of this study, low income will be described as a family's taxable income for a year which did not exceed $125 \%$ of the federal poverty level amount described by the United States Census Bureau (Choy, 2001). For 2012, the US Census Bureau defines poverty as a family income of less than $\$ 15,130$ for a two person family, $\$ 19,090$ for a three person family and $\$ 23,050$ for a four person family.

Phenomenological approach. Creswell (2003) describes a phenomenological approach to research as "studying a small number of subjects through extensive and prolonged engagement to develop patterns concerning a phenomenon as described by participants in the study" (p. 15).

Peer debriefing. Creswell (2003) describes peer debriefing as a process that involves "locating a person (a peer debriefer) who reviews and asks questions about the qualitative study so that the account will resonate with people other than the researcher" (p. 196). 
Purposeful sampling. According to Cresswell (2003), when participants of a study are limited to those who have experienced the phenomenon being studied the sampling procedure is described as purposeful sampling.

Qualitative research. Qualitative research allows a researcher to gain a general understanding of the group being studied through narrative discussions and to construct meaning from experiences (Creswell, 2003). Characteristics of qualitative studies include (1) occurring in a natural setting, (2) using interactive and humanistic methods that involved the participants of the study, (3) developing ideas or theories based upon the information gathered in the study, (3) interpreting the data to develop themes or categories to draw conclusions, (4) using the participants own words as often as possible to tell their stories, and (5) using inductive and deductive processes to determine the meaning of the data.

Social challenges. The extent to which a student has knowledge of, exposure to, and support for earning a college education influences the level of social difficulties the student experiences.

Social integration. A student is likely to be socially integrated into an institution when there is a match between a student's social values, preferences, and behavioral styles with those that characterize other members of the institutional community and a student forms personal bonds with students, faculty, and staff (Tinto, 1993).

Social support. Social support entails students building a significant relationship with people who support the goals of college education. This support can be obtained from members of the campus community, the local community, or family (Tinto, 1993).

Student success. Throughout this study, student success will be determined as a student who was approximately halfway through a program of study. (This definition is derived from 
concepts taken from Cofer and Somer's (2000) study that after their first year of college, FGCS are more likely to persist; King's (2003) report that students who attend college full-time are more likely to complete a degree; and Braxton et al.'s assertion that the greater a student's level of commitment to an institution, the greater the likelihood of the student persisting in college.)

Trustworthiness. According to Vogt and Johnson (2011), trustworthy is the term used in qualitative studies to indicate the researcher has accurately recorded what the participants of the study have responded. In addition, trustworthiness describes the extent to which the findings and statements accurately represents what the participants of the study have responded. 


\section{Chapter 3: Research Design and Methodology}

As Chapter Two indicated, researchers have examined the Tinto (1993) model of student persistence and its application to college students, how the experiences of first-generation college students (FGCS) differ from those of students who have family members familiar with college, and what is being done on college campuses to enhance retention. However, there has been little exploration of what successful community college FGCS do to compensate for their frequent lack of academic preparation, financial knowledge and resources, and social support. The existing research on community colleges has focused on single institutions and their programs and as such, limits the generalizability of the findings. This study examines FGCS who have been successful in seeking a college education and provides information about what firstgeneration community college students did to help themselves overcome the challenges they faced as they sought to further their education. For the purpose of this study, success was defined as a student who was approximately halfway through a program of study and was likely to complete the program. At this point, the participants had persisted long enough to be able to reflect on how their goals had or had not changed and were committed to reaching them.

\section{Population and Sample}

Community colleges are a large component of postsecondary education in the United States. According to the Carnegie Foundation for the Advancement of Teaching in 2012 there were 1,714 institutions offering only associate's degrees and certifications. These institutions represented $37.0 \%$ of all higher education institutions. With an average enrollment of 4,506 students, community colleges included $37.3 \%$ of all students in higher education. Within the community college system, $60.2 \%$ were public institutions accounting for $95 \%$ of all community college students. 
Nationally, $43 \%$ of the students beginning their college careers in the fall of 1989 were first-generation college students (NCES, 2005b). While community colleges represented 39.4\% of all students in higher education (Carnegie Foundation for the Advancement of Teaching, 2005), a large portion of students attending community colleges were the first in their family to attend college (FGCS). Research has indicated that $51 \%$ of FGCS are likely to attend two-year or community colleges (Nunez \& Cuccaro-Alamin, 1998).

The institutions selected for this study were public, two-year colleges offering Associate's degrees and certification programs only (Carnegie Foundation for the Advancement of Teaching, 2005). Of all community colleges, $13.7 \%$ were classified as small with an average enrollment of 1,426 students and $8.4 \%$ were classified as medium with an average enrollment of 5,241 students. The small and medium colleges represented $22.1 \%$ of all community colleges. In total, $14.2 \%$ of all students at community colleges were found at small and medium institutions. The institutions selected for this study were limited to representatives of the nearly one quarter of all community colleges that fall into the small and medium two-year categories (Carnegie Foundation for the Advancement of Teaching, 2012).

This study examined students at two-year colleges (Carnegie Classification of Higher Education, 2005) who were within the first generation of their family to attend college and had completed approximately one-half of their certificate program or Associate's degree or planned to transfer to a four-year institution to pursue a Bachelor's degree. I interviewed community college students to gather data regarding their experiences as first-generation college students. I asked each of the colleges for permission to conduct the study on their campuses and for them to provide the names and contact information for 45 students meeting the study's criteria. Upon receiving permission from a college (Appendix F) and contact information for students, I 
planned to randomly contact 20 of the identified students at each college and request their participation in the study. My goal was to interview at least 10 students at each campus for a total of 30 students and the extra invited students were necessary since some students would not respond or would decline to participate.

Limiting participants to students who have experienced the challenge of being the first in their family to attend college is described as purposeful sampling (p. 20, Creswell, 2003) and the associated community college sample was a convenience sample. Participants of this study were selected based upon the following criteria:

1. Within the first generation of their immediate family to attend college;

2. Enrolled in any program of study which culminates in a degree or certification;

3. Either part-time or full-time enrollment;

4. Completed approximately half of the courses in their program for degree or certification;

5. Completed the majority of their courses at the institution in which they are currently enrolled;

6. Representing males and females;

7. Traditional (18 to 22 years) or non-traditional aged (over 22 years) students.

\section{Design}

There has been little research on how first-generation college students (FGCS) at community colleges are successful. As a result, this study explored the experiences of FGCS by using a qualitative research design. Qualitative research “focuses on people's experience from their perspective" (Roberts, 2004, p. 111). The intent of qualitative research is often to describe an experience (Strauss \& Corbin, 1990) more than to find a cause for the experience. Roberts 
(2004) summarizes that in using a qualitative approach, researchers seek a "comprehensive and complete understanding of the phenomena they are studying" (p. 111). Qualitative methods focus on the participants and acknowledges that there are variations in participants' experiences (Auerbach \& Silverstein, 2003). In addition, as a collaboration between the researcher and the participants, it is more likely that qualitative research will be relevant to improving the lives of the participants (Auerbach \& Silverstein, 2003).

The overall intent of this study is to expand the knowledge base of what FGCS experience while in college so administrators and colleges can distribute their resources to help students be successful. By using qualitative methods, I explore the experiences of FGCS to gain a better understanding of their unique experiences in seeking an education. Creswell (2003) describes qualitative approaches as allowing the researcher to construct meaning from the experiences of the participants. Researchers who conduct qualitative studies (1) examine how things occur, (2) examine what the participants' perspectives are and why that is their perspective, (3) develop ideas or theories as opposed to testing an existing theory, (4) describe in-depth participant responses to explain the findings of the study, and (5) present an emergent and flexible design based upon the study (Aloi, 2004).

The design of this study used individual interviews of study participants. Interviews provide a more structured method of soliciting information than would a study based upon observations because I directed the line of questioning (Creswell, 2003). By using interviews, I was able to (a) develop a detailed description of the experiences of FGCS, (b) integrate the perspectives of many different people, (c) develop a description of how community colleges have worked for FGCS, and (d) learn how FGCS interpret their experiences (Weiss, 1994). As a qualitative researcher, I use narratives to describe the participants' experiences thus providing a 
more detailed and in-depth understanding of their experiences than would be permitted through quantitative analysis (Creswell, 2003). This study is a phenomenologically-oriented study given my examination of a small number of participants and resultant identification of patterns of experiences and relationships of meanings (Creswell, 2003).

The conceptual framework is based on Tinto's Model of Student Departure as shown in Figure 1. An interview protocol was developed to address each of the categories of the conceptual framework and to address the research question. Issues I considered as I collected the data were:

1. Why do first generation college students enter college? What are their goals?

2. What academic, financial, and social challenges do first generation college students face in college?

3. Where and to what extent have students found social support?

4. How have students' concerns about financing their education been addressed?

5. In what ways have students been assisted in meeting academic demands?

6. How committed are students to completing their academic degrees or programs?

The majority of the questions in the interview protocol were open-ended. Questions that use pre-determined categories are limiting in that they force participants to make a choice within pre-determined categories that may not accurately portray their experiences. Open-ended questions allow the participant to describe their experiences and behaviors in their own words, thus providing fewer limitations and more details. The questions were used to solicit information about students' academic, financial, and social experiences. The interview questions included demographic information in addition to questions specifically oriented toward the research question about the participants' experiences and opinions. The interview questions 
corresponding to each area of the theoretical framework are listed in Table 1. Demographic questions in the protocol were used to confirm students' first-generation status and to determine if there were similarities and differences between demographic groups.

Table 1

Research question - Interview Question Congruence

\begin{tabular}{|c|c|c|}
\hline & Research Area & Interview Question \\
\hline \multirow[t]{4}{*}{ Pre College } & Academic Preparation & 16,17 \\
\hline & Financial Resources & 3 \\
\hline & Social Support & 23,25 \\
\hline & $\begin{array}{l}\text { Goals, Commitments, \& Intentions to enter } \\
\text { college }\end{array}$ & $9,13 a$ \\
\hline \multirow[t]{5}{*}{ Post Entry } & Academic Involvement and Integration & $\begin{array}{l}15,17,18,19,21 \mathrm{~b}, 21, \mathrm{c} 21 \mathrm{~d}, \\
35,36\end{array}$ \\
\hline & Social Involvement and Integration & $20,21 \mathrm{a}, 22,24,2627,28$ \\
\hline & Financial Resources & $29,30,31$ \\
\hline & Goals, Commitments, \& Intentions to continue & $4,5,10,11,12,13 b, 14,32$ \\
\hline & college & 33,34 \\
\hline
\end{tabular}

\section{Pilot Study}

Before proceeding with the study as a whole, I conducted a pilot of the study. A pilot study is a small-scale trial of the study (Fraenkel \& Wallen, 2000). The purpose of a pilot study is to identify and correct any problems associated with the design or protocol (Fraenkel \& Wallen, 2000).A pilot study was conducted in the Fall Semester of 2006 providing me the 
opportunity to practice interview techniques, field note-taking, and transcription and data analysis skills.

Upon receiving Institutional Research Board approval from West Virginia University, I identified an institution with characteristics similar to those identified for the main study and in close proximity to my location for accessibility. The pilot study was conducted at a small, public, non-residential Bachelor/Associate's college. Once I identified the institution, I contacted the Director of Institutional Research asking for permission to conduct the pilot study and for referral to students meeting the specified criterion of being first-generation college students (Appendix A). I asked the Director of Institutional Research to provide a letter granting permission to conduct the study, to identify 15 students who met the study's criteria, and institutional level financial and academic data (Appendix B).

Pilot study results. The Director of Institutional Research and the Executive Dean of Academic Affairs informed me that the institution was unable to identify which students were first-generation. The Executive Dean of Academic Affairs offered to provide a list of first-year students in addition to allowing me to use personal contacts to solicit participants. The Dean of Students also contacted me offering to provide a list of students in first-year seminars who were willing to participate in the study. As a result of the institution's difficulty in providing only firstgeneration students, I altered future requests for institutions to identify students as reflected in the section about the main study data collection.

While the institution for the pilot study did provide the institutional data requested, they had a great deal of difficulty doing so and there was a long delay. As a result of these issues, I explored other avenues of obtaining the requested data for the main study. In the end, I examined the importance of the data on remedial coursework to the study and opted to eliminate that 
component from consideration. While the data would add interest to the study results, it was not crucial for reporting the results.

I interviewed two male and one female first-generation college students using the designed protocol (see Appendix C). All three interviews were audio-taped with the participants' permission. I coded and analyzed the participants' responses. The participants did not suggest any changes in the protocol but upon analysis, I found the participants did not consistently focus on the topic of the question. For example, when asked about their most significant academic challenges in college, the first two participants focused more heavily on financial challenges. I made minor changes to the interview protocol in terms of the order and wording of the questions based on the participants' responses after the first and second interviews. These changes were made to clarify responses and to probe for more in depth answers. With these changes, the third interview provided clearer and more focused responses.

\section{Main Study}

Data collection. At the beginning of the study, I identified eight community colleges in Michigan and Ohio meeting the criteria for the study of being public institutions and categorized as small or medium by the Carnegie Classification of Institutions of Higher Education. I contacted the person in charge of institutional research at each of these institutions to ask for permission to conduct the study on their campus and for access to students (Appendix F).

As a result of only one of the original eight institutions agreeing to participant in the study, several institutions declining to participate, and my relocation to another area of the United States, I identified additional institutions with similar characteristics as those originally identified. In all, I identified more than 20 additional institutions in West Virginia, Texas, Louisiana, and Arkansas with similar criteria. I requested permission from these additional 
institutions to conduct the study. Two additional community colleges agreed to participate in the study for a total of three research sites as listed in Table 2.

Table 2

2012 Characteristics of Participating Community Colleges

\begin{tabular}{lcccc}
\hline \multicolumn{1}{c}{ Institution } & Enrollment no. & Profile & Size & Location \\
\hline Great Lakes Community College & $4,000-5,000$ & MIX2 & M2 & Rural \\
\hline Community College of Appalachia & $3,000-4,000$ & MIX2 & M2 & Rural \\
\hline Southern Community College & $1,000-2,000$ & MIX2 & S2 & Rural \\
\hline
\end{tabular}

Note. Information collected from the Carnegie Foundation for Teaching (2012) and the US Census Bureau (2012a \& 2012b).

For the main study, I presented colleges with options of how I could recruit participants for my study. I asked the institutions to either identify a large number of students and allow me to contact students directly to screen out students who were not FGCS, for the institution to grant me permission to work with faculty members about speaking to their students so I could recruit volunteers, or any other method they believed was appropriate. One college allowed me to contact faculty and arrange to speak with classes about my study to recruit potential participants. A second institution scheduled appointments for me with students who met my criteria. The third institution forwarded my request to participate to all students and provided me the opportunity to speak with students about the study through information sessions and public information tables.

Once I gained permission from each of the three institutions to conduct the study, I contacted potential participants as agreed upon by the college (see Table 3 ). Throughout the process, the students were reassured of their anonymity and volunteer status and asked to schedule a time to meet with me (see Appendix G). Once students agreed to participate in the 
study, I conducted individual interviews based upon a protocol of open-ended questions (see Appendix H). In all, I interviewed 24 participants at the three colleges. While there were questions common to all interviews, the protocol allowed for follow-up questions in order to clarify participants' responses. I recorded the semi-structured interviews through notes and audio-taping. I maintained participant confidentiality by not revealing to individual institutions which students participated in the study, ensuring no one other than myself had access to interview notes, using participant first names only, and by using pseudonyms for the individual participants as well as for the institutions to reduce the possibility that individual participants could be identified.

Table 3

Study Participants

\begin{tabular}{cccccccc}
\hline & & $18-22$ & $23-26$ & $27-35$ & $36-45$ & $46+$ & Total \\
\hline Gender & Male & 3 & 1 & 1 & 1 & 2 & 8 \\
\hline & Female & 3 & 5 & 3 & 2 & 3 & 16 \\
\hline
\end{tabular}

Data analysis and interpretation. Once I completed interviews at each college, I transcribed and coded the interviews. I used deductive analysis for coding the interviews and looked for trends and commonalities between responses. Deductive analysis incorporates an existing framework with the data (Patton, 2002). I also used issue focused data analysis to describe what was learned from the participants about other FGCS (Weiss, 1994). I analyzed significant statements, generated meaning, and developed a description of the participants' experiences (Creswell, 2003).

The coding and analysis were based upon the philosophical framework of the study, 
Tinto's model of student departure (see Figure 1). As I coded and analyzed the participants' responses, I examined: (1) how prepared students believed they were for college; (2) what kind of support and encouragement they received to begin college; (3) what financial resources they had available to them to begin college; (4) why they entered college; and (5) what their goals were for entering college. In order to assess the extent of the participants' academic integration into the institution, I reviewed their responses to determine: (1) what academic challenges they experienced in college; (2) what parts of the academic system of the college were they comfortable using; and (3) how often did they participate in the academic system of the college. To assess the participants' social integration into the college, I examined: (1) what social challenges they experienced; (2) how involved in the social system of the college they were; and (3) what part of the social system of the college did they feel comfortable using. To assess how the participants addressed their financial needs, I examined their responses to determine: (1) what financial challenges they experienced; (2) what college sponsored financial resources they accessed; and (3) what methods of addressing their financial challenges they used after they began college. To gain a better understanding of how committed the participants were to the institution and if they were likely to persist or depart, I examined: (1) how committed were they to pursing an education; (2) how close were the participants to completing their programs; (3) what plans did they have to complete their programs in a timely manner; and (4) how did they plan to use their education.

The data analysis involved multiple steps. One characteristic of open-ended interviewing is the potential for a participant to provide information that does not address the question. In turn, the first step was to identify relevant text from the interviews. Relevant text is defined as that text which is related to the research concerns (Auerbach \& Silverstein, 2003). The second step was to 
identify ideas repeated throughout interviews. I then analyzed the data for recurring ideas and themes and integrating selected quotes from students to illustrate their stories (Creswell, 2003). Based upon these ideas and themes, I provided a theoretical narrative summarizing how the data addressed the research concerns (Auerbach \& Silverstein, 2003).

I used multiple strategies to check the trustworthiness of my findings. One strategy I used was presenting my own experiences as a FGCS so readers would be aware of potential bias on my part. In order to enhance trustworthiness, I also presented all information, including any which contrasted with the general themes of the study (Creswell, 2003). Lastly, I had a peer review of the study and findings in order to ensure other researchers were able to understand how I came to the conclusions I described (Creswell, 2003).

The data from this study provided a clearer picture of the experiences of FGCS but did not attempt to identify causal relationships between FGCS and their experiences (Creswell, 2003). Creswell (2003) states the use of peer review provides the opportunity for a reviewer to ask questions about the study and ensure the findings ring true with people other than myself

\section{Researcher Identity}

The purpose of this section is to explain how my own background and experiences may have influenced the research process. Understanding the role individual experiences and biases play in the research process is especially critical when the researcher is also the tool for data collection and analysis. In this section, I will explain my own experience as it relates to the study.

The origins of this study can be traced back to my own experiences as an FGCS. I experienced many of the challenges described to in the study's literature review. I was academically unprepared, had very limited financial resources, and struggled against family 
expectations and traditions to gain family support for attending college.

My academic preparation was not as strong as many other college students' and the preparation I did have derived mainly from being fortunate to make decisions which ended up helping me. Throughout my primary and secondary school years, academics were not a strong focus at home. While I was expected to not do poorly, there was not a focus on high academic achievement. When I did do homework, I would be criticized for taking too long to do it. In junior and senior high school, I would frequently be reprimanded for going to my room to study and not spending time with my family. At that point, my idea of studying was to simply read the information over and over or to complete assigned homework. Upon reflection, I believe I finally learned how to study my junior year in college.

Since my family and their friends were not familiar with college, I did not have anyone to advise me on what I would need to do to be prepared for college or how to navigate the processes and procedures necessary to earn a college education. In grade school I was involved in a school activity which I decided I wanted to make a career when I graduated high school and somehow understood that career would require a college degree. During my seventh or eighth grade years, I stumbled across a high school curriculum guide that listed different types of high school diplomas. Through these materials I found there was a "college preparatory" track of courses. I thought since I had decided I wanted to attend college that would be a helpful track to follow so I could get into college. In spite of my selecting college preparatory courses and meeting with advisors each year to plan my classes the following year, no one ever asked if I wanted to attend college or suggested future career opportunities and I did not know to ask anyone about it. Somehow, I managed to stumble along and complete the basic college preparatory courses by the time I graduated high school. 
During my senior year of high school I started researching which colleges in the area offered the degree in which I had an interest. I sought out materials from those colleges. My focus was on state colleges because I knew private schools were more expensive and still did not know how I would pay for school. In the end, I chose the state college that was least expensive and closest to my family.

Throughout my undergraduate experience, I encountered information that made me wonder how other students knew what to do but I did not. I thought I had missed getting the information somewhere along the way. My lack of knowledge about college included the most basic things. At the time, I attributed my lack of knowledge to poor high school advising and, during really difficult times, viewed myself as not capable of being in college. For example, I was totally oblivious to the fact that tutoring and supplemental instruction was available for some courses. The few times I was aware of these tutoring services, I believed they would cost extra money and spending more money was not an option for me. When I struggled academically, I thought I just needed to work harder and that maybe I just was not smart enough to attend college.

My lack of understanding did not end with earning my Bachelor's degree. It followed me to graduate school. When it came time for graduate school, I did not know to ask my advisor for help. I did not understand the process of how to apply for and choose a graduate school. After I got to graduate school and began asking teachers and advisors for help when I struggled academically, I was disheartened by their refusal to help. Again, I thought that I must have missed some information along my educational road or I would not be having difficulties.

When I first announced that I was going to college, my family was extremely resistant. My parents quickly informed me that I would have to find my own way to pay for school 
because they were not going to do so. Once my grandmother found out, she continuously criticized my decision saying it was useless and that I should be focusing on getting married, starting a family, and getting a job. Over several years, I continued to be persistent that I would attend college. While I was in high school, my parents started supporting my decision. By the time I graduated high school they committed to providing me financial assistance. My grandmother never changed her mind and while she stopped publically criticizing my decision, she was never supportive of it. However, as much as my parents provided a great deal of moral support, their understanding of the experiences I would have in seeking a college degree was very limited. They did not have the background and knowledge to advise me. Throughout my college career, I had to navigate the world of higher education on my own.

Financially, like many other FGCS, I struggled to find ways to pay for college. Throughout my life, my parents had worked multiple jobs to pay bills and provide for our family. When I decided to attend college, I expected to have to find my own way of paying for school. Shortly before high school graduation, my parents told me they would help me pay for college. I knew this placed a major financial burden on them. I applied for financial aid but did not receive any. The financial aid department at my chosen school said my parents made too much money and my grades were not good enough for scholarships. I did not know anything about student loans and could not ask my parents to take out loans in their names.

Every class was a financial struggle. It was a yearly challenge of which I was fully aware. I knew my mother's entire paycheck was going toward paying for my school even though I was working and cutting expenses in every way I could find. With my mother's death between my sophomore and junior year, finances became even more strained since her wages were not available to pay for school. I applied for and accepted a Resident Assistant job mostly because it 
would pay for my room with a small stipend I could use to buy groceries. When I graduated with my Bachelor's degree, I knew that I needed to find a way to pay for my Master's without asking for help from my father. I worked multiple jobs and took out student loans to cover my Master's degree.

I have worked on a variety of campuses in various parts of the nation as an administrator. This experience has provided me with the opportunity to learn about higher education from the administrative side and to learn about the many resources available to students. Two of my jobs served administrative functions at universities. One focused specifically on academic administration while the other focused on out of class administrative activities. This was the point of my life when I started noticing other people were having the same problems I encountered. I switched to studying student affairs believing I could help other students get the information that I had missed and help them navigate the higher education process. In my positions working on college campuses I learned more about financial aid, academic assistance, and other services on campus. I became convinced that for some reason this information was not getting out to all students. The more I reached out to help students get the information I wished I would have had, the more I noticed other people were having the same problems I had. Then I started noticing that many of these students were the only people in their families to attend college. I also noticed the people who were experiencing these problems were intelligent people from across the country. These observations made me wonder if perhaps, the problem with lack of information was centered in the education system, not with those students who do not know the answers.

As this study progressed, I realized that while many of the characteristics of FGCS apply to me as well, there are many more that do not. Yes, my academic preparation was not as strong 
as it could have been. However, learning remained a priority in my family and I did have the opportunity to take quality college preparatory classes while many other FGCS do not. I may have been raised in a family where finances were a constant struggle so financing a college education was difficult. However, my parents made many sacrifices to ensure each of their children, including me, had more opportunities than they had. While my family was not able to provide advice about navigating higher education, they have continued to provide moral support and encouragement. Many of the people who agreed to take part in my study were not as fortunate. Within this study, I attempted to provide a voice for FGCS to explain how they have been successful in seeking an education.

Anticipated ethical issues. Qualitative research provides the researcher with the opportunity to get to know the participants personally. However, this personal contact with participants can lead to revelations which may be sensitive to the participants. I took the following steps in order to protect the participants' rights: (1) presented the purpose of the research including how the data would be used both verbally and in writing; (2) maintained participant confidentiality: and (3) obtained an exemption from the West Virginia University Institutional Review Board (Appendix I).

Limitations. There are a number of limitations to this study. One limitation of the study derives from the limited size of the sample. Fraenkel and Wallen (2000) explain a population is more accurately represented the larger the random sample size. The small sample size and convenience sampling of the study limits the ability to generalize the results of this study to that of the population as a whole.

A second limitation develops from the low number of institutions represented in the study. Students of the three institutions included in the study may not be representative of FGCS 
of other institutions in other areas of the country.

A third limitation was its reliance on self-reported information from students. Selfreported data tends to be less reliable than objectively obtained data. Participants may forget or exaggerate their experiences. In addition, the longer the information is gathered after the event itself, the less reliable a person's memory will be. In addition, by relying solely on participant self-reports there was no triangulation to determine if their reports were accurate.

A fourth limitation derived from my level of involvement as the researcher. Qualitative research methods require more personal involvement with the subject matter and participants than other research methods. I worked with individual students to collect data. This personal involvement may have me to interpret and analyze data in a different manner than other researchers. In order to reduce the effect of this bias, I asked FGCS to review the findings, presented contrasting data, and used participants' own words to describe their experiences.

This chapter described the methodology used in the study. The purpose of the study and the research questions were reviewed. The population and sample involved in the study were detailed. A description of the study design, data collection, and analysis methods was provided along with information about a pilot study. The chapter ended with a summary of the limitations of the study. 


\section{Chapter 4: Community College of the Great Lakes}

This chapter reviews the experiences of participants from the Community College of the Great Lakes (CCGL). It begins with a description of the institution then continues with general descriptions of each of the participants. Next, there is a discussion of their pre-college academic preparation, social support, and financial resources. Afterwards, there is a discussion of the participants' experiences integrating into the academic and social systems of the college and obtaining the financial resources they needed to continue their educations. The chapter ends with a summary of the participants' experiences and how those experiences influenced the participants' decisions to continue their education.

\section{Institutional Background}

The Community College of the Great Lakes (CCGL) is a medium sized, two-year state funded college located in a rural region of the United States' Midwest with an enrollment of approximately 3,000 students (Carnegie Foundation for Teaching, 2007). In the mid-twentieth century, members of two local intermediate districts and five local school districts within a two county region endorsed the formation of a community college. The college's first classes were offered within ten years of this endorsement. Since its founding, the main campus of the college expanded and a branch campus opened in a neighboring community.

The facilities for the institution's two locations are about 20 miles apart and easily accessible from a highway that serves as a main artery for the region. Classes on the campuses are housed in a single building on the branch campus and in a building with multiple connected wings on the main campus. On both of the campuses, students have access to a campus bookstore, student service offices such as financial aid and advising, and study areas, some of which contain computing facilities. The main campus is located in a rural area with little industry 
and no other institutions of higher education. The branch is located in a city of approximately 25,000 that is also home to a large state-funded university classified as a doctoral research institution (Carnegie Foundation for the Advancement of Teaching, 2007). The branch campus is the newer of the two facilities and is a three-floor building. There is little on this campus beyond the classroom facilities.

The general education (Math and English) and some of the major program faculty serve both campuses by offering courses on alternating days at each campus. In addition, the faculty members have offices on both campuses that they share with another faculty member. Some of the major specific courses are offered only on one campus and students as well as faculty travel to that campus for their courses.

The college describes its purpose as providing educational and community leadership in order for members of the community to develop their abilities. To achieve this purpose, the college aims to provide education and services that enable students and members of the community to achieve success in a global society (CCGL Catalog, 2007). The college's goals are to:

1. Provide educational opportunities which will prepare students to transfer to baccalaureate institutions or add to their life skills...;

2. Provide educational opportunities which will prepare students for successful employment in business, health, and technical occupations...;

3. Provide counseling and guidance for students regarding decisions related to education...; and

4. Provide community service by meeting educational, recreational, and cultural needs of the college community... (CCGL Catalog, 2007). 
In order to assist students in selecting the appropriate introductory Math and English courses, the college conducts placement tests for incoming first time students. The college uses the results of these placement tests to recommend to students which English and Math courses they should initially take. However, students are not mandated to take remedial or developmental courses based upon placement test results.

\section{Study Participants}

I contacted the college requesting permission to conduct this study in addition to assistance in identifying students classified as first-generation college students who had completed half of their program requirements. The administrator referred me to two faculty members who might have an interest in the area of study. I contacted both faculty members, explained the purpose and goals of the study, and asked for assistance in identifying participants. One of the faculty members responded with an offer to help with the project. Upon further discussion, she agreed to have me attend those of her classes where students were most likely to meet the criteria desired for the study. Before I arrived at the college, she spoke with students she knew to be first-generation college and encouraged them to consider participating in the study. Upon my arrival at the college, she also introduced me to other faculty members who agreed for me to speak to their classes.

My faculty liaison described the student populations on the two campuses very differently. She said she found the students on the main campus much more engaged in their education than those students on the branch campus. She based her opinion on a pattern of the main campus students attending and participating in her classes more often. Many of the students the faculty member instructed on the branch campus had been unsuccessful at the local state university and were taking classes at the community college for readmission to the university. 
In total, I spoke to six classes about the study. I explained the rationale for and importance of the study in addition to assuring the confidentiality of the participants and their responses. Ten students volunteered to participate in the study. Eight of these students scheduled times for individual interviews, but two of the students did not attend the scheduled interviews.

The participants from CCGL represent a variety of backgrounds and experiences. I interviewed six students, five female and one male. They ranged in age from 18 to 46 years of age and are all within the first generation of their families to attend college. Linda is a White single student, who was 18 at the time of the study. Her father earned a GED and her mother graduated high school and attended college for two semesters. Mary, who was 23 at the time of the study, is a White mother of three children. Her mother is a high school graduate who received further training in the U.S. Navy and her adoptive father graduated from high school. Barb is a white, divorced mother who was 46 at the time of the study. Barb's mother graduated from high school and her father dropped out of school after the eighth grade. Of her four siblings, one received certification in a technical trade and one earned an Associate's degree in business. Jim is a single, White student who was 24 at the time of the study. Neither of his parents attended college prior to his beginning college but once he started college, his mother earned an Associate's degree. One of his siblings attended college to obtain trade skills. Patty, who was 26 at the time of the study, is Hispanic, White, and Native American and a mother. She is the only child of a mother who graduated high school and attended one semester of college. Liz is a White student who was 27 at the time of the study. Neither of her parents attended college. Of her four siblings, two entered college but neither completed a degree.

\section{Pre-College Characteristics}

FGCS encounter a number of roadblocks in their attempts to obtain a college degree. 
These roadblocks center round their academic preparation, support, and financial resources leading up to developing their educational goals for entering college.

Academic preparation. The participants demonstrated a range of academic preparation for college. Some followed a traditional path to higher education and entered college directly from high school while others returned to school after several years. Linda, Jim, and Barb began college directly after high school while the other three participants pursued college in less traditional manners. Linda took classes continuously after high school, but Jim and Barb pursued their educations in a start and stop pattern. Liz waited for four years to begin her college education whereas Patty and Mary earned GEDs before pursuing college educations. In spite of the different paths they took to college, like participants in other studies (Chen \& Carroll, 2005; Horn \& Nunez, 2000; Humphrey, 2000; Terenzini et al., 1996), the participants for the most part were not prepared for college.

Linda is the only participant who pursued a college education in a traditional manner. She graduated high school and entered directly into college. However, she was no more prepared while in high school for the academic demands of college than were the other participants. She did not have difficulty in Math and English but did have difficulty with science courses such as biology and chemistry. Linda explained her high school had not required courses to prepare for college, they were optional. She said, “my high school didn't say you had to do this, it was optional and so luckily I got into some classes like my English composition and that helped me a lot out here." While she believed CCGL did a good job helping people adapt, when asked what she would tell administrators they needed to do to help FGCS, Linda suggested:

I would just go to the high schools. Because that's where the problem is not being prepared. I know a lot of people who went to bigger universities and they had to drop out 
and come to a community college because it was too stressful.

Jim and Barb are two other participants who initially entered college directly from high school. However, unlike Linda, they both left college for some time before re-entering college to complete their degrees. Academically, Jim believes he had the knowledge he needed to be successful in college but had not truly been prepared for everything college would entail. The area where he had difficulties was in understanding the amount of work he would encounter at college. He said, “I wasn't prepared at all for [his initial college]... That just blew my mind. That was amazing." When he was in high school, his counselors did not educate him on the resources and options that were available. He explained, "The counselors in high school are kind of "this is what you need to do' not 'this is what you can do'." When Jim was asked directly if he would make the same choices again, he said no. He would have taken more time to explore his options and ask questions. He explained, "I didn't even know what a computer engineer was. I just knew that I was good at computers and that was what I liked to do. I didn't research anything."

Barb also originally began college directly from high school. She believes she was academically prepared for college at that time. However, by her third attempt at college, she believes she was not prepared. She explained:

I think a lot of the introductory classes are a little bit more advanced than some might think. They're tough classes and I'm not a dummy, but I found myself struggling and they're a lot more advanced than you would think, I think that was the biggest shocker this time around.

Barb attributes her lack of preparation to the length of time that passed between her graduation from high school and her third attempt at college. She believes students graduating from high school today know more than students did when she graduated high school. She 
explained:

More is expected of you. Because of that, we're competing, especially older people, are competing with younger students that have grown up through a whole generation of being computer literate, computer savvy and a lot more is expected of you.

Liz waited for four years after graduating from high school to enroll in college. She believes she was prepared for college in high school but thinks the amount of time that lapsed between high school and college led to her forgetting basic academic information. She found college harder than she thought it would be. She described her biggest academic challenge as knowing what to expect. Although Liz said she was prepared for college, she also described having academic difficulties in her second attempt at the same course. Her difficulties demonstrate a lack of readiness.

Patty and Mary took the most non-traditional paths to college of the participants at CCGL. They both dropped out of school and later earned GEDs so they could attend college. Although neither of them could attribute academic preparation to their high schools, they have different perspectives on their academic preparation. Patty does not believe she was academically prepared for college while Mary does.

Patty had been out of school for a number of years. In her initial enrollment at college, she took one or two classes at a time. Based upon her experiences when she began college, Patty reported she was not prepared for college. She had not known what to expect as a college student and did not know how to function in the college environment. Patty said she had never been a very good student in high school so once she enrolled in college her biggest academic challenge was determining her learning style.

Mary had dropped out of middle school at 14 when she became pregnant. However, by 
the time she earned her GED and began college, Mary believes she was prepared for college. Once she decided to attend college, she prepared for and earned a GED. Instead of dropping out of school being an academic disadvantage for her, Mary believes she had an advantage over other students because she had not learned bad habits in high school and was used to being a self-directed learner. She attributed her academic skills to her personal experiences. She explained:

I think life skills really helped out a lot. I wouldn't ever advise it but I think that getting pregnant at such an early age and, I had to become a mom you know, and I didn't put my son up for adoption, and I didn't push him off on my mother. I took responsibility for things I had done and I just dealt with it and moved on and I really think that life had, had helped me out a whole lot.

Financial resources. Students' financial resources also play a critical role in their integration to colleges' academic and social systems. Without the financial resources they need to participate in the systems, students are not able to academically and socially integrate into college. Horn and Nunez (2000) reported FGCS tend to have limited financial resources.

The participants of this study supported those findings. Their lack of financial resources served as a major roadblock for many of the participants in pursuing college educations. Although Mary's husband worked full-time, if she did not have access to financial aid programs, she would not be able to attend college. Linda was employed but still needed a way to supplement her wages to pay for tuition and books. Barb battled un-employment difficulties and could not have pursued attending college without financial assistance. She described her financial situation as “excruciating." Jim's family was in too high of an income bracket for him to be eligible for financial aid. However, they did not contribute to his college expenses. In order 
to attend college, he had to find a way to pay for it on his own. He explained finances were "one of my biggest stressors." While in high school, Liz was aware her parents did not have the financial resources to send her to college but they made too much money for her to receive financial aid. Liz explained maybe "if there was something in place, well you know, we have this [financial aid program], I would have tried a little harder in high school and went right out of high school." Linda explained her family was a one-income family so she had limited financial resources. One consideration for her choice of college was the expense. She chose CCGL in part because "classes don't cost as much as they do in other places."

Social support. Tinto (1993) found support plays a critical role in students' goals of seeking college educations. Non-FGCS are encouraged from a young age to attend college upon graduating high school. However, Horn and Nunez (2000) reported this is not often the case for FGCS. Some of the experiences of the participants of this study are consistent with these findings while others dispute those findings.

Three of the participants; Jim, Liz, and Patty; were encouraged from a young age to attend college which is inconsistent with the findings from Horn and Nunez (2000). Upon being asked when he had first been encouraged to attend college, Jim explained his family "would always mention how important school was." Based upon that encouragement, he entered college directly after high school. Liz and Patty on the other hand were encouraged from a young age to attend college but in spite of that encouragement, had not been motivated to do so when they first graduated high school. Liz explained her parents "always said it was good" to attend college but she did not do so until several years later. Although Patty's family had always encouraged her to attend college, she did not begin until she found the internal motivation to do so.

In contrast, the other three participants of the study did not receive the same 
encouragement. Mary, Linda, and Barb were adults or nearly adults before they were encouraged to pursue a college education. Their encouragement came from family, teachers, and public services employees. Mary originally dropped out of school at 14 but was interested in furthering her education. Because her husband knew she was interested in pursuing a college degree, when she was 19 years old he used her interest as motivation to obtain her GED. She explained, "He started talking about college but kept reminding me that I had to get the GED first."

Barb had been interested in attending college when she first graduated high school but had been unsuccessful in her early attempts. Her struggle to be successful in college developed when she began having children:

I just didn't have the family resources so I justified that 'I can always go back to school but God won't grant me a lifetime to have children so I'll drop out of school, I can go back to school at any time.'

She attempted to re-enter college 10 years later at a nearby medium-sized state university but left after two semesters for the same reasons. By the time of the study, Barb had been laid off from her job twice in a three-year period and when the state offered to have her retrained in another field, she entered college again. She explained, “I jumped at the opportunity. I just didn't even think twice about it."

Linda was not encouraged to attend college when she was young. It was not until she reached high school that someone began encouraging her to attend college. This encouragement came from Linda's high school teachers. When asked how they encouraged her, Linda explained teachers informed her of how people with more education "get paid better because they can do more things."

Goals and intentions. Van T. Bui (2002) reported FGCS have a wide range of reasons 
for entering college. The participants of this study were no different. They provided three main reasons for seeking college educations that included a general desire to improve their job opportunities, to set positive examples, and to achieve personal goals.

Barb, Jim, and Liz all entered college with a general desire to improve their opportunities in jobs. Barb was very specific about what she considered improved job opportunities. For her, improved job opportunities meant specific hours and a stable future demand for the field. Her general goal for attending college was "I want an 8 to 5, Monday thru Friday. I want to get in someplace where I can retire.” For these reasons, she chose to be retrained as a Medical Assistant. Medical Assistant is a field in high demand, met her criteria, and was as close as she "could get to being a nurse without doing shiftwork."

Jim had less specific goals for attending college. When he first began college, he wanted to increase his job options and to have "a better career than the average person." During his first attempt at college, Jim decided to pursue Computer Engineering. Although he had chosen a major, he did not have a specific career in mind for when he completed the degree. His academic goal was to take as many classes as possible, as quickly as possible, so he could have a degree. In his most recent attempt at college, his goals changed. He selected a new major in which he had more interest and believed he would be successful. He also had a different approach to his education. Instead of hurrying to get his degree, he said:

I'd rather take my time and make sure that I'm doing everything the way I want to do it than just try and you know, put my head down and charge right through like I was doing when I got out of high school.

Liz's initial reason for attending college was to have better job opportunities. When she initially entered college, she chose a major in Nursing. She explained that once she had her 
daughter, she believed "I needed a better education, a better job since there is just the two of us." Patty decided to attend college in order to be a better role model for her children. She explained she did not believe she had been a good role model prior to attending college. Patty wanted to be as educated as possible and to be able to help her children when they had questions about school. With an education, she believes she will be able to have a career where she can more successfully support her family.

Mary and Linda both entered college because they had specific goals they wanted to achieve. Mary decided to attend college for general self-improvement. She wanted to have a job that paid well and to work somewhere where she could have pride in the job she was doing. Mary had concluded that neither would be possible without a college degree. Prior to earning her GED and beginning college, Mary lied on resumes and applications saying she had graduated when she had not. She believed dropping out of school was a hindrance for her. She explained:

I would say I graduated high school and I didn't. I know there was a time when my son'd come home and needed help with homework and I was going to have no idea how. And when he started getting smart enough, 'cause I've always, since he could talk, really pushed college you know, and he's only eight and wants to go to [an academically prestigious college] and you know, how could I tell him to go to college when I never did?

Linda began college in order to be able to pursue a specific professional field. She wanted to be a veterinarian, work with animals and "and make a good amount of money, to be able to travel." She knew she needed to go to college in order to be able to do so. She explained, "A lot of my friends go to college so I would feel left out if I didn’t go too.” 


\section{Post-College Entry}

Even after entering college, students still have a number of hurdles to pass before they successfully graduate. The participants of the study discussed their experiences with the academic and social systems of the college as well as their financial resources, goals, and commitments. These aspects all influence students' abilities to be academically and socially integrated into a college. Successful integration into the academic and social systems of the college plays a critical role to the success of students' pursuits of higher education (Tinto, 1975). When students are successfully integrated into college, their commitments to college and intentions to complete their educations influence their decisions to continue through to graduation or to depart the college.

Academic involvement and integration. Once students enter college, a factor contributing to their successful completion of a degree or program is the extent to which they are integrated into the academic system of the college (Tinto, 1975). Students who are academically integrated find a match between their skills, interests, and needs with the academic characteristics demanded by the college. The perceptions students have of a match can be enhanced through positive academic performance and interactions with faculty and staff.

Academic challenges. Students' academic preparation is a critical component to their classroom experiences in college (Nora, Attinasi, \& Matonak, 1990) and their positive academic performance. Although colleges expect students to enter with basic academic knowledge and skills, many FGCS do not (Fallon, 1997). Students who do not have strong academic preparation often experience difficulties in college classes and thus may not find a fit between their own skills and interests with those expected by the college. Academic preparation proved to be a challenge for the participants of this study. They demonstrated poor preparation through their 
references to academic challenges in college level coursework.

When prompted to describe any academic challenges they had experienced, the participants most frequently referenced the absence of general study skills and academic abilities. Their experiences support the findings of Van T. Bui (2002) which reported FGCS are less prepared for college. Jim explained his initial four-year college "had a class that I was supposed to be doing and going to but I didn't even have the habits to get that class done." However, the participants frequently did not blame their academic challenges on poor academic preparation in their prior educational experiences or a lack of assistance in learning the skills at their present institution. Instead, four of the participants attributed their challenges to their own deficiencies.

As Fallon (1997) discussed, FGCS often do not attribute their deficiencies to poor academic preparation but instead to juggling the demands of their lives. One participant, Mary, attributed her academic challenges to her inability to focus. She described her biggest academic challenge as learning to focus instead of trying to multi-task. She explained, "If I could just study, I would do just fine. But fitting all of that into my life has been pretty, I think, pretty hard.” In spite of acknowledging this as a challenge for herself, Mary did not describe any assistance in learning those skills before entering college or at her entry into college.

Another participant, Liz, attributed her academic challenges to her inability to select courses and to manage her time as well as to a general lack of academic knowledge. The previous semester Liz had taken four classes and "had a really hard time because I was going full-time, and I couldn't handle it at all." In order to address this problem, Liz reduced her course load to two classes. Liz did not reference receiving any advice about how many classes to take or how to manage her time. Unlike those students described by Damashek (2003) who were failing 
and had to be coerced into accepting help, Liz sought assistance. Unfortunately, her attempt was not successful and she did not seek any other assistance. She explained:

They have the ASC [Academic Support Center] but I went there the last semester of my chemistry. They took my information and said they were going to get me a tutor and they never did so when I went back there they had lost my information.

Patty, a third participant, cited the number of years she had been out of school before entering college and her own lack of ability as the reasons she experienced difficulties. She explained she had to "re-learn how to learn" because she had been out of school for a number of years. Like those students mentioned by Humphrey (2002), Patty realized she lacked the skills she needed for college. She explained that she had never considered herself a "great" student anyway. However, she also described knowing she needed to get an education but not knowing what to do to make it happen. She approached the college's admissions office and they showed her what she needed to do to be admitted, to register, and to get financial aid. Then they showed her career books and hiring levels for different careers to help her select a major. She did not report any type of assistance in matching her skills and abilities to a career path.

A fourth participant, Jim, related the challenges he experienced to his own inadequate study skills. He described his biggest academic challenge as learning how to study. Once he entered college, he found he needed to study much more than he had in high school. Jim explained the initial institution he attended provided first-year seminars designed to help students enhance their study skills. However, in line with those FGCS described by Damashek (2003) he did not have the basic study skills needed to attend the classes. To further complicate his integration into the academic component of the college, he also described an advisor registering him for 19 hours his first semester without him understanding the significance of that step. 
All four of these participants attributed their academic difficulties to their own inadequacies and not to poor preparation through their previous educational experiences. However, the experiences these participants described demonstrated a lack of preparation through previous educational experiences on how to navigate the bureaucracy of the college environment as well as on how to be successful in their classes. While research has shown that FGCS do not have the informal exposure to higher education (Fallon, 1997) where they learn how to navigate the higher education environment, these participants also did not find assistance in learning those skills through their previous institutions or even their current college.

FGCS often do not have the opportunity to be informally exposed to the higher education environment (Fallon, 1997). The participants made it apparent they lacked this exposure and their educational institutions did little to help them learn about the environment. They often described not having a basic understanding of the demands of college classes and the academic environments they would encounter in college when they first entered college.

Linda explained when she first enrolled in college she simply did not understand the "effort that would have to go into it." Jim reported he was completely unaware of what he would encounter and was unprepared for the first college he attended out of high school. In describing his first semester of college, Jim reported, “They signed me up for 19 credit hours. I didn't know what 19 credit hours meant. Obviously, I know now that that's a pretty heavy load and that you have to be prepared to do something like that."

Not only did their previous educational experiences fail to prepare the participants for college, once they entered college, they did not receive the help they needed to develop skills to be successful. Although CCGL required students to see an academic advisor in order to register, the requirement was only for students' first 12 hours. Often students complete 12 hours within 
their first semester as a full-time student. This does not provide ample time for the students to learn how to navigate a higher education environment that may be alien to them.

As is typical with first generation college students, the participants generally described a lack of preparation for the academic content of their courses. Not only did their previous educational experiences not prepare them, college did little to help gain the knowledge they needed to be successful. Although CCGL provides a tutoring center as well as faculty to help students, both sources depend on students taking the first step to ask for help. Previous research details the likelihood that students who are failing are unlikely to seek out assistance on their own (Damashek, 2003).

Many of the participants referred to their lack of understanding of the demands of being a college student as more of a challenge than the coursework itself but upon further questioning, it was clear that they struggled with academic content as well. The majority of the participants referenced difficulties in courses. Like many other students who are unprepared for college, they frequently referenced taking remedial or developmental courses or repeating courses (Horn \& Berger, 2004; Kazis \& Liebowitz, 2003), both of which demonstrates a lack of academic preparation for college-level study. Barb reported she found the knowledge required for introductory classes more advanced than she had expected, but rationalized her lack of knowledge was the result of a change of knowledge base for recent graduates. She believed recent graduates entering college directly from high school knew more than she had learned by the time she graduated high school. Although Barb could justify her lack of preparation as the result of changing standards in secondary education, these changes could not explain other participants' difficulties. Other participants also reported difficulty in at least one subject including Math, English, Chemistry, or Biology. 
Academic assistance resources. In order to overcome their academic deficiencies and difficulties, the participants found resources to help them be academically successful. Even though the participants as a whole did not cite the same resources for acquiring the academic skills they needed to be successful in college, most of the participants were able to reference at least two resources. The participants referred to using campus resources and community members, taking beginner coursework; learning from failures, and self-motivation to help them overcome their academic challenges.

Campus resources proved to be one source of academic support for the participants. The most common campus resources participants cited using were the Academic Resource Center, instructors, and peers. Although participants referenced campus resources, the specific resources they used varied from one person to the next. Patty reported success in seeking help from both the Academic Resource Center and instructors. Barb reported she went to classmates or the instructor when she needed help. Although Linda referred to the Academic Support Center as a possible resource, she explained she had never attempted to obtain help there. Instead, she worked her troubles out herself, went to the instructor, or participated in Supplemental Instruction when it was offered. Jim described the widest range of use of campus resources. He recounted experiences of seeking help from the Academic Resource Center, instructors, and peers. Although they used a variety of resources, the participants most often sought assistance from instructors.

Most but not all participants described extensive academic resources at their disposals. Liz reported very limited success in finding resources to help her. Her first attempt to seek assistance was an unsuccessful one at the Academic Success Center. She explained the Academic Success Center took her information and said they would call her back when they got 
a tutor arranged. A month later, she returned to follow up with the Center and discovered they had lost her information. After that experience, she did not seek assistance of any type until shortly before participating in the study. A few weeks before participating in the study, Liz began studying with a classmate.

One participant reported being more successful in seeking help from resources outside of the college than from those within the college. Mary explained she initially sought assistance from the Academic Support Center for Math and English but felt she had been overlooked and ignored. After her negative experience with the Academic Support Center, she focused on finding support from outside the college. Her primary sources of support were her minister, her husband, and the Internet. When her questions related specifically to her major, she sought help from her minister who had studied a similar field. For general academic help, Mary went to her husband. However, in keeping with her attitude of self-reliance and problem solving, the primary resource she used was the Internet. Mary explained:

I Google everything and I don't take one specific answer from one web site. I check several different places and try to draw my own consensus too. Like when I have a Math problems, I'll go to several different Math sites to try to help develop the answer that I need or the way to get that answer.

Developmental coursework. When students do not have the skills necessary to be academically successful, some enroll in development or remedial classes to learn those skills (Horn \& Berger, 2004; Kazis \& Liebowitz, 2003). Like many other FGCS (Duggan, 2001) four of the participants; Liz, Patty, Mary, and Jim; enrolled in developmental courses. They reported either their scores on the placement tests reflected a need to take courses to prepare them for beginning college level work or based on self-assessment they made the decision to do so 
regardless of their placement test results. Although Liz had not been required to take a placement test at the college because she had transferred from another college, she had done so at a previous college. When she initially took a placement test, the results from the test reflected a need to take a beginner class before she enrolled in the college level course for the subject. Patty and Mary both chose to take basic Math and English courses instead of the college level courses their placement tests had recommended. Jim elected to take a lower level English class than what the scores on his placement test recommended he should take. Jim, like many FGCS, was well aware that he was not academically prepared for college (Humphrey, 2000). He explained, 'I've never been a really great English student and so coming here and knowing that I struggle with English a little bit. I started with beginner English courses.”

Interaction with faculty, staff, and administrators. Graunke and Woosley (2005) outlined the positive impact of students' satisfaction with their opportunities to interact with faculty. Although the majority of the out of class interactions the participants reported occurred with faculty and staff, it varied from one participant to the next how frequently they interacted with faculty and ranged from often to seldom. Linda referred to frequent out of class interactions with faculty while Liz explained she only interacted with faculty during class. Barb and Jim both said they interacted with faculty out of the classroom a couple of times per semester but only when they had questions or concerns about academic requirements. Patty explained the amount of interactions she had with faculty depended upon the class. In general, she typically spoke with faculty once or twice a semester but she had been interacting with one faculty member weekly because she was taking the course as an honor's class and wanted to ensure she earned good grades. One thread that was common to all of the participants was that the participants' out of class interactions with faculty members were typically limited to academic topics and focused on 
specific coursework. Even Mary who reported out of class interactions with faculty which were not academically related, revealed those interactions were limited to casual greetings.

The participants also described out of class interactions with staff and administrators on the campus. However, these interactions focused on addressing specific needs. Jim reported frequent contact with a departmental secretary. However, Jim interacted with her when he needed to contact someone within the college. Linda, Barb, and Liz also indicated regular interactions with staff and administrators. However, they too interacted with staff and administrators regarding academic activities. Their interactions centered on activities such as registration and financial aid processes. Linda interacted with staff and administrators each semester when she was taking care of academic concerns such as registration but rarely found the need to interact with them at other times of the year. Patty interacted more often with staff and administrators than she did with faculty but only interacted with them every month or two when she had questions related to her education. There is little chance the participants explored or discussed their academic skills, interests, and needs with staff and administrators since their conversations revolved almost exclusively around specific tasks, not around long term pursuits. In spite of their limited out of class interactions with faculty, staff, and administrators, the participants did not report feeling uncomfortable with the interactions. Jim explained, "I usually go to my teacher, my instructor, especially here. They always seem to have time to talk."

Based on their responses, all but one of the participants demonstrated they were integrated into the academic system of the college at least to some extent. The participants, except Liz, each described being committed to their programs and to having academic success. Liz described the most difficulty with academic performance. In order to be more academically successful, she took steps such as changing her major to one she believed would be less difficult 
and reducing her course load to less than full-time. With her continued struggles, Liz demonstrated a possible lack of match between her skills and needs with the academic characteristics demanded by the college.

Attribution of success. While the participants took complete responsibility for their academic challenges, most did not hesitate to share the credit for their academic successes. They attributed their academic success to a combination of their own efforts, the quality of faculty at the college, and the assistance of their families. Jim, Patty, and Barb all attributed their success to themselves as well as to the support of their families. Although Jim initially reported he attributed his success to faith in his abilities, he later cited the support he received from family and friends. At first, Patty also said without her own motivation and faith in her ability to succeed, she would not have been successful but later also credited the support of her family and faculty. Barb attributed her success not only to her own efforts but also to the support she received from her boyfriend. Liz was the only participant who did not attribute her success in any way to her own skills and efforts. She explained she was successful because of the support she received from her family. Mary initially reported her success was the result of the faculty at the college but later said she believed FGCS had to be internally motivated in order to be successful. Linda was the only participant who attributed her success entirely to herself. She explained she had been successful through her own efforts and study habits.

In spite of having difficulties with specific subjects, at least two of the participants found academic success. Two of the participants, Mary and Barb, attributed their academic successes to their personal experiences. Mary explained the personal challenges she had overcome led to her problem solving skills and her ability to think independently, and ultimately academic success. Barb believed her experiences in the workforce provided her the skills she needed to be 
successful in college. She explained:

You usually have a boss or a supervisor that is telling you or critiquing you. There's always somebody there to tell you what you need to do and I think it just crosses over to the educational system even though you're maybe not studying everything that you want to study, you still have somebody in a hierarchy position that you are taking orders from and you have to do the work or you won't get a good grade.

Jim attributed his success at CCGL to his previous lack of success in college. He believed he was more successful in this, his third, attempt at college because his previous lack of success in college had taught him what he needed to do differently. He explained, "This is my third time in college so, this time is going good. It's going smooth, I know what's going on and I know how to study and do my homework."

Two of the participants reported their personal characteristics were what had led to their success. They explained they relied upon self-motivation and perseverance to be academically successful. Linda attributed her success almost entirely to the effort she had expended. When asked to what she would attribute her success, she explained she was academically successful because she, "Just studied, tried. Put in effort. I have my own little goals that I wanna reach and that helps me strive towards them." Mary believed FGCS students had to be self-motivated in order to be successful. She explained:

I think that to be successful, be a first-generation successful college student, it's got to come from within. I think you could pretty much baby them the entire way through to make sure they were successful, do everything, and if they have it up in their mind and they have the road blocks up and they are just positive that they are going to have a crappy experience and they're not going to do good and they're going to fail, and they're 
not going to be successful because their mom and dad weren't successful and brothers, they're not gonna to do good no matter what you do.

Social involvement and integration. A second area Tinto (1993) identified as critical to student persistence in college was that of social integration into college. According to Joseph (1995), a critical component of students' persistence in college is the degree to which they are integrated into the social system of the college. For the purposes of this study, students' comfort level on campus, reported social challenges, and amount of out of class interaction with peers demonstrated their degree of social integration.

Comfort level. All six of the participants in this study reported feeling comfortable on the campus. They referred to their comfort in terms of lack of problems on campus, a pleasing atmosphere in the community, and their knowledge of and similarities to other students. When asked directly if they were comfortable on campus, all of the participants said they were. Liz said she felt the most comfortable at CCGL of all three colleges she had attended. She could not provide specific examples of why she was more comfortable but had an overall impression that the faculty at the college cared more than those at the other colleges she had attended.

Linda and Jim described their familiarity with and similarity to other students as a component of their comfort level. Many of the students from Linda's high school attended CCGL. She attributed her comfort on campus to knowing many of the students. Jim found the people at the college to be friendly and the community itself to be a close-knit group. He attributed his comfort level at least in part to these characteristics. He reported many of the students were in similar situations and had similar families so he felt they could relate to each other in some way.

Barb attributed her comfort level on campus to its atmosphere. She believed the 
atmosphere of the campus was more appropriate for her personal situation. She explained:

On this type of campus, I will say it's more conducive to the reentry student because it isn't the dorm life. It isn't the network of the dorm life where everyone's coming in from all over where on the other campus [her previous college] it was really geared to the social inter-workings of being on campus and having on-campus activities and involvement.

Social challenges. The number of challenges participants experienced also reflected their degree of social integration. The participants cited few social challenges on campus. The reasons they gave for not having social challenges varied from one person to the next. Linda attributed her lack of social challenges on campus to knowing so many of the students from high school. Barb explained she did not have social challenges because she was a social butterfly that made friends wherever she went.

Interaction with peers. In spite of their reported comfort on campus, the participants did not experience many social interactions and connections through the campus. Three of the participants; Liz, Patty, and Mary; depicted themselves as loners. Liz reported she did not interact with members of the campus and explained "I just kind of stick to myself." Patty described herself as "anti-social" and said she did not interact with others on a regular basis. The only participant who directly reported having social challenges was Mary. She found it difficult to make friends with other students. She believed that since she was a young married mother, people her own age were at a different stage in their lives and did not share much in common with her. As a result, she did not attempt to socialize with other students. She explained, "I have a hard time making friends. I come here to get my education and leave. I haven't really incorporated my education in with my life as far as social aspects." Because of her belief that she 
did not have very much in common with other students, Mary seldom interacted with members of the campus community. Even Linda who initially reported knowing many people on campus because of them attending the same high school explained she preferred to find a quiet place by herself and study when she was not in class. She said, "Mainly I seclude myself into a little hole downstairs. I have my spot, the janitors know me, so I'm not bugged."

In general, the participants simply did not interact with their fellow students outside of class. Barb, Jim, Patty, Liz, Linda, and Mary all reported their primary focus when on campus was to attend class. Although Barb described herself as a social butterfly, she also reported she did not interact with students outside of class. Jim explained he seldom interacted with his fellow students. He attributed his lack of out of class interaction to the fact that the students with whom he did associate lived out of town and, as a result, he did not interact with them out of class any more than three or four times a semester. Patty initially reported she occasionally interacted with other students. However, upon further discussion, she explained these interactions centered on arranging rides for class related activities. Liz also described very limited out of class interactions with other students. The only out of class interaction she had was to study with a classmate on campus. After much prompting, she revealed this out of class interaction had been occurring for less than a month. Linda was the only participant who reported she had frequent interactions with students. Although she reported knowing many of the students on campus, she later explained the students with whom she interacted were her boyfriend's friends, not her own. Mary explained, “I haven't really incorporated my education in with my life as far as social aspects. Because I've never felt comfortable with students my own age, anybody, even if they're not students."

The participants' lack of out of class interactions with other students was even more 
obvious when they discussed their involvement in student organizations and activities. Each of the participants reported very limited involvement in student organizations and activities. Only one of the participants reported being involved in a student organization. Jim had just joined his first student organization shortly before participating in the study so had not had prior experience with it and did not participate in student activities. Patty was not a member of any student organizations and had only participated in one activity. The single activity in which she participated was a help fair her instructor had organized. Barb was invited to join a student group but said, "I turned them down because they probably don't want a 46 year old in their sorority." Mary said she did not belong to any student organizations because her out of class experiences were centered on her family. She said, "I didn't want my life in the school to end up, taking up time with my son, so I decided not to do it." As a whole, the participants reported few out of class interactions with members of the campus community including their peers. Their responses demonstrated a lack of integration into the social system of the college.

Support. Based upon the participants' responses, members of the campus community did not serve as a major source of support for the participants. While their responses may have demonstrated a lack of social integration into the campus community, the participants felt supported in their endeavors. Upon being asked directly if they received support for attending college, all of the participants except one confirmed they indeed received support. Their sources of support were their families, members of the campus community, and members of the surrounding community.

For most of the participants, their families served as major sources of support in their pursuits of a college education. Each of the participants explained their families provided some sort of support although that support varied from one participant to the next. Jim and Liz 
described their families as supportive even though they had both previously been unsuccessful in pursing their educations. Jim's family and friends displayed their support by asking about his coursework and celebrating his successes with him. Liz's family supported her by offering the opportunity to live at home and attend CCGL. She described her parents' assistance as invaluable. She explained:

My parents watch my daughter while I go here, while I go to school. So if it wasn't for them I wouldn't be able to. I was working downstate, working full-time, and just taking a class or two and finally I just said I can't do this, work full-time and try to pay rent and stuff, so I quit my job and moved up here and now I just work for them at their store and they watch her while I go to school.

Patty explained most, but not all, of her family were very supportive of her college endeavors. Her family's support included asking about classes, praising her for going to college and being enthusiastic for her when things went well. On a more concrete level, they provided childcare when she was in class and helped provide transportation when she needed it. However, not all of her family was supportive. Patty described her grandfather as critical of her attending college. His criticism centered on the amount of time that had elapsed since she graduated high school before enrolling in college and her lack of specific career goals. Patty explained her grandfather told her it was a waste of time for her to attend college and repeatedly said she would not be successful. Instead of deterring Patty from college, her grandfather's criticism served as a source of motivation to prove him wrong.

The support Mary and Barb received on the other hand was not from immediate family members. Instead, their support came from significant others. Mary explained most of the members of her immediate family were limited in their abilities to provide support because they 
lived far away and were extremely busy with their own lives. However, she reported her husband had been very helpful throughout her college experiences from encouraging her to begin college to assisting with coursework. She explained, "My husband has helped out a lot. He does a lot. He almost feels like he's gone to college with me without getting the credits for it."

Barb's main source of support was her boyfriend. She explained in addition to providing moral support by understanding how important attending college was to her, he also understood and respected her need for quiet and study time in order to be successful. Barb said her mother was generally supportive of her attending college. However, that was not always the case. When Barb re-enrolled in college, her mother questioned the necessity and benefit of seeking a degree. Barb explained that her mother had originally questioned her decision because she did not understand the economic difficulties Barb was facing, knew attending college was a lot of work, and that Barb had struggled in previous attempts at college.

Linda was the one participant who said she did not have any support. When asked who had been the biggest supporters of her attending college she said, "Nobody. My parents don't really care." She reported her academic achievements were the result of her own determination and effort. However, she did reference a way her mother was supportive of her even though she did not label it as such. She reported her mother helped her with financial aid paperwork so she could attend college.

While Tinto (1993) emphasized the importance of students being integrated into the social system of a college and interacting with their peers at college, the participants of this study did not express that need. Instead, most of the participants of this study found support from family and significant others for their pursuit of a college education.

Financial resources. Students' need to obtain financial resources does not end with their 
admission to college. CCGL offers a number of programs to help students meet expenses related to pursing a college degree. These programs include federal aid through grants and loans; state aid through scholarships, grants, and loans; privately funded academic scholarships; institutionally funded academic scholarships; and personally funded educational trust and savings plans for students and their families to pre-plan for the expenses associated with attending college.

In spite of its many programs to help students meet their financial needs, CCGL as an institution is heavily reliant on student tuition and fees to provide operating funds. Approximately $16.5 \%$ of the college's overall revenue comes from state support of the college and more than $73 \%$ of its revenue comes from student tuition and fees. Scholarships and grants sponsored as a part of the college's general budget as well as those sponsored by a separate foundation total less than $0.35 \%$ of the overall operating budget for the college. The college's reliance on tuition and fees to function places a larger financial burden on the students.

For students with limited financial resources, the burden to pay for college may become overwhelming. The participants of this study turned to a variety of sources to obtain the money they need to pay for college and for advice on how to obtain that assistance. Financial aid, state funded programs, low-income assistance, and employment contributed to making their pursuits of higher education possible.

A main source of finances for the participants was financial aid. All of the participants reported receiving some sort of financial aid through scholarships, grants, and loans. Patty reported relying the most on financial aid to attend college. She reported she received a "full ride" through various financial aid programs. However, even though she considered herself as receiving a "full ride," the grants only covered her school expenses. She needed to obtain student 
loans to cover her living expenses.

Although the other participants did not report as much reliance on financial aid as Patty did, they still found financial aid programs an important aspect to being able to seek an education. Mary explained financial aid was an essential contribution to her ability to pursue an education. Although her husband worked full-time, she also received a grant that covered most of her educational expenses and she took out loans and worked approximately 20 hours a week at the college through work-study. She explained she was concerned about finances because, "I think there's going to be a day when I'm not going to receive any more Pell Grants and that's going to be a struggle because classes are very expensive." When Barb was laid off from her job, the state offered her the opportunity to return to college and be re-trained in a field that was in economic demand. As a part of this retraining program, Barb received financial aid. In addition, she also received a need based grant and low-income assistance. Although Liz reported her parents assisted her with college expenses, their help did not cover all of her expenses. Liz relied on grants and loans to supplement the financial assistance her family provided. Linda, the youngest of the participants, received some grants and scholarships related to her high school achievements that helped cover the financial demands of attending college.

Even with the assistance of financial aid, the participants struggled to find the financial resources they needed not only to attend college but also to cover living expenses. Barb's experience in financing her education was "excruciating." She explained financial aid and her eligibility for a state funded re-training program were essential and if it were not for those programs, "none of this would be possible." Even with these two monetary sources of support, Barb also relied on low-income assistance to cover basic essentials such as food and living expenses. Patty, who described her financial aid as a "full ride," also found the need to be 
cautious about her available funds. She explained she calculated the total amount of grants and loans she would receive and carefully monitored her budget to ensure expenses did not exceed the amount of awarded aid. Linda explained the amount of money she was allotted by grants and scholarships was not so large as to eliminate any financial concerns she had. In discussing her financial situation, she explained the amount of financial assistance she received influenced her decision to attend CCGL. Because she had the perception that the cost of attending CCGL was lower than that of attending other colleges, she believed the amount of financial aid she received was adequate for her needs but still pursued external financial resources.

Although the participants may have received financial aid through college, they faced financial challenges. Each of the participants alluded to some sort of compromise or sacrifice they made in order to make attending college possible. For some participants their compromises and sacrifices were minor but for other participants, their decisions were much more critical. Mary and her husband monitored their budget very closely and limited expenses they considered non-essential so she could attend college.

Other participants made more critical sacrifices in order to pursue their education. Jim and Barb gave up the wages and benefits they received as full-time employees so they could attend college. Jim, Barb, and Linda all found it necessary to work in order to meet their financial needs. Jim had accumulated considerable debt prior to taking classes at CCGL so had to earn money to meet those obligations in addition to paying for current college expenses. As a result, he worked two jobs with an average of 30 hours per week while attending college. Although the reason she had the opportunity to attend college when she was laid off because of a state supported re-training program, Barb found it was impossible to find a steady job because of class related schedule constraints. However, she worked odd jobs to earn money and "had to sell 
a lot of my own personal property in order to make ends meet." Even though she had not given up a full-time job to attend college, Linda also felt the pressure of meeting financial demands. She reported she worked a minimum of 13 hours a week at one job and an additional 30 hours a week at a second seasonal job. Even with working these jobs, she explained she did not believe the amount of money she earned relieved her financial burdens.

Another source of financial assistance for some participants came from family. Liz, Linda, and Jim referenced some sort of assistance regarding finances from family members. One participant, Liz, not only received money from her parents but they also allowed her to live with them to reduce her living expenses, she worked at their business to earn money, and they provided her financial advice when she needed it. Linda's family provided assistance by allowing her to live with them and her mother helped her with financial aid paperwork. Jim reported his father and grandparents had helped him with finances one time. The other participants relied upon themselves or the financial aid office for any financial assistance they needed.

Financial advice. The participants described how their difficulties in meeting the financial demands of college continued even after they began college. Their difficulties included obtaining financial advice as well as obtaining money to pay for college expenses. The college provided resources to advise students on meeting their financial obligations. However, the participants did not take full advantage of these resources. Participants' failure to use the available resources could be linked to either inadequate quality of resources or the participants' lack of comfort in asking for the advice. Some participants described seeking help but not being successful in obtaining it. Other participants reported being self-reliant in learning about which options were available as well as the steps necessary to obtain money. 
In addition to their challenges in obtaining money for college, the participants had few sources to advise them on how to address their financial concerns. The primary sources of assistance for the participants were the college's financial aid office and family members. The help the Financial Aid Office provided typically consisted of assisting the participants with completing paperwork not of informing them of resources and methods to pay for college. Not all of the participants took advantage of this limited assistance of the financial aid office. Two participants, Jim and Patty, reported they completed the paperwork on-line and the financial aid office simply informed them which aid programs they were eligible to use. Mary explained she initially sought assistance from the financial aid office but had not been comfortable with the experience. Her experience supports Hughes (1990) report of a significant correlation between students' satisfaction level with the financial aid office and whether or not the staff made the students feel comfortable. In addition, a first impression takes only a few seconds to form and takes seven additional visits to change that first impression (Chitty, 2008). When asked about her experience with the financial aid office, Mary explained:

You walk up to a desk and you talk to a lady behind the desk and there's four or five people standing behind you. And you're having to give all this personal information about finances, 'cause they need socials and; they say how much you have and how much. So they have a lot of personal information and I got a pretty funny look when I asked them if I could make an appointment to maybe talk to somebody in a room, away from fifty other students.

Goals and commitments. Tinto (1993) emphasized the importance of students' commitment to their education in their persistence in college. Once they entered college, successful participants may have changed their programs of study but they were committed to 
meeting their new educational goals. Their success could be traced through their continued goals of attending college, satisfaction with and commitment to their college and programs, and desires to complete degrees in a timely manner.

Post-entry goals. Each of the participants maintained a commitment to reaching their educational goals. Of the participants interviewed, Barb and Liz plan to earn Associate's degrees while Linda, Jim, Patty, and Mary plan to earn Bachelor's degrees or higher. Participants who had plans beyond an Associate's degree also set incremental goals in specific major areas that would help them reach their final educational goals. For example, Liz has plans to earn an Associate's degree in Radiology to help her reach her goal of being a certified ultrasound technician. Patty and Linda plans to earn Associate's degrees in order to transfer to outside institutions for Bachelor's degrees. Each of the participants expressed enthusiasm for continuing their educations. Liz said if she had it to do again, she would have done better in her classes and taken college "more seriously."

Although committed to completing their educational goals at the time of the study, some of the participants had altered their goals from when they originally began college. Two of the participants decided to earn degrees requiring less time while two others set goals that would require more education and another changed his educational goals to better meet his personal skills and interests. With their changes came increased commitments to their goals.

Two of the participants had originally planned to earn Bachelor's degrees but by the time of the study had decided to earn Associate's degrees. They both reported their change in goals was a better fit to their life goals. Liz said, “At first I was going for nursing but then I changed it to radiology because they have radiology here.” Liz believed radiology was a better fit for her academic skills and availability. She explained she had not done well with the nursing classes 
and was not satisfied with the long wait list to enter the program so reassessed her goals and selected radiology. When she first began college, Barb planned to be a Nurse. As years passed, Barb realized her personal goal was to have a job that was not shiftwork. By the time of the study, she had changed to a Medical Assistant Associate's degree. She explained her reason for changing was that a Medical Assistant Associate's degree was “as close to being a Nurse as I can be without having to assume shiftwork."

Two of the participants who reported they initially began college to improve themselves had later set more specific goals of earning Bachelor's degrees or above. Mary and Patty had both entered college to take classes and improve themselves. By the time of the study both had set goals for specific fields. In addition, a motivating factor for them to meet their goals was to set positive examples for their children.

Another participant, Jim, had not been academically successful in the past when he initially began college. As a result, he reassessed the match between his original major and his skills and interests. With these criteria in mind, Jim switched to nursing and decided he wanted to earn a Bachelor's degree or higher. He explained his new program in Nursing was a much better fit for him than his initial major in engineering.

Although their amount of detail varied, each of the participants had ideas on how they wanted to use their degrees. Liz and Barb planned to earn Associate's degrees and were specific about their career goals. Liz explained she was pursing an Associate's degree so she could be trained as an ultrasound technician after she got a job. Barb described her reason for pursing an Associate's degree was to have a job that was "an 8 to 5, Monday thru Friday." She explained, "I want to get in someplace where I can retire."

Three of the four participants who planned to earn Bachelor's degrees or higher were less 
specific about their career goals. Jim knew he wanted initially to work in an Emergency Room Trauma setting but was not sure what direction he would take with his career after that experience. He intended to continue his education but was unsure which fields may be of interest to him for future education. Linda explained, "I wanna travel and do a lot of that but when I'm 40, I wanna work at a zoo for the rest of my life I wanna run a zoo or an animal shelter or something." Mary had a goal of earning at least a Bachelor's degree and explained she was working toward her Associate's degree in order to have a job while pursuing Bachelor's, Master's, and Doctoral degrees. Her final educational goal was to have a terminal degree in Psychology. However, she has not decided how she wants to use that degree. She explained, "I preferably would like to have my own practice but I think that they need something better in the school systems for children." The fourth participant who planned to earn a Bachelor's degree or higher, Patty, was the only one who had a specific career in mind. She planned to earn an Associate's degree in order to transfer to another college and earn a Bachelor's degree to work in the Criminal Justice system with Probation or Parole.

Post-entry commitment. Students who are committed to an institution or program are more likely to persist (Bers \& Smith, 1991; Tinto 1993). While several of the participants had originally enrolled at other institutions, they all reported being committed to and satisfied with the education they are receiving at CCGL. Each of the participants with the exception of Linda reported they would enroll at CCGL if they had to make the choice again. However, Linda who was from the local high school, reported she would attend another college. This preference is not related to dissatisfaction in her education at CCGL but instead to her desire to have different experiences and meet different people.

Mary and Jim were very complimentary about the quality of education they received at 
the college and were very committed to the institution. Mary explained she did not believe she could have found better instructors at any other institution. Jim explained he believed the faculty at CCGL were focused on instructing whereas at another institution his experience had been the faculty provided guidelines so students could teach themselves.

All but two of the participants would choose the same major or program if they had to reenter college. Barb and Linda both believed their chosen programs were a good fit for them personally. Mary explained she would re-enter the same program because she believes it will help her reach her career goals. She said, “The nursing program is a stepping stone to psychology, and that's...where my heart lies." Patty explained she would choose the same program again because she is very pleased with the quality and professional experiences of her instructors. She explained because the instructors are professionals in the field, "They paint a realistic picture of what it will be like in that field and are honest and up front about the risks involved."

The two participants who reported they would choose different programs than when they first began college were Liz and Jim. They both had changed their programs of study between when they first entered college and when they participated in the study. Although Liz had changed programs from when she originally entered college, her new program was in a related field. She had changed from nursing to radiology. In explaining the change she said, "I guess I felt I had a better chance at it because my grades weren't that great.” However, she reported being pleased with the program she was in at the time of the study. Jim was the only participant who reported he would have chosen a vastly different program from the one he initially selected when he began college. He reported being very pleased with his current program and said he would choose it again. He explained CCGL “...has a wonderful reputation for nursing. So that, 
you know, that really makes me want to stick with it. I know that they have tough classes, they have a tough program, but yet I like the challenge."

The participants were committed to completing their programs in a timely manner. Cofer and Somers (2000) reported students enrolled as full-time were more likely to persist. Five of the six participants were enrolled as full-time students. Jim, Barb, and Linda were enrolled full-time when they participated in the study. For Liz and Patty, their full-time status was a change from their past pattern of enrollment. At her previous institution, Liz had been taking one class at a time. With the additional help she began receiving from her family, she was able to enroll as a full-time student when she was at CCGL. Similarly, Patty reported she originally had taken classes on a part-time basis but for the previous two years had been doing so on a full-time basis. Only one of the participants was not enrolled as a full-time student. Mary had previously enrolled on a full-time basis but for that particular term she was enrolled for less. She intended to continue enrolling on a half or three-quarter time basis because she was concerned if she enrolled full-time, she would not be able to devote enough time to studying while still caring for her son. Horn and Berger (2004) found the likelihood of students remaining in college increased as students progressed through their programs. The participants of the study were halfway through their programs and had specific plans to finish their programs. Mary, Linda, Barb, and Patty intended to finish their degrees in a year or less and had completed at least half of the credit hours needed for their programs. Jim expected to finish a Bachelor's degree within two and a half years. Liz was the least confident of her status. She was not sure how many hours she needed to finish her degree but she expected to finish within two years.

A common characteristic among the majority of the participants is the concern for the amount of time and effort expended on studying. Terenzini et al. (1996) found although FGCS 
are not academically prepared for college and gain more than their non-FGCS counterparts by studying, they are less likely to do so. As a group, the participants spent little time preparing for their classes. Liz spent the least amount of time preparing for classes each week. She studied an average of only five hours a week although she was enrolled as a full-time student. Barb did better in expending time to prepare for class at an average of 10 to 15 hours a week. Patty did not appear to have a set amount of schedule of class preparation. She initially described her amount of studying as "a lot" but upon further prompting reported studying approximately 12 hours per week. However, she did explain that if she had a class that required more studying, she spent more than 12 hours a week. Linda spent the most amount of time preparing for class. She scheduled a minimum of two hours a day for studying and squeezed in extra study time when business was slow at her work. In all, she estimated she studied around 25 hours per week. As full-time students Liz, Patty, and Linda spent an average of only one hour per week for each enrolled hour preparing for class. Linda spent the most amount of time preparing for class with an average of two hours per enrolled hour. 


\section{Chapter 5: Community College of Appalachia}

This chapter reviews the experiences of participants from the Community College of Appalachia (CCA). It begins with descriptions of CCA and each of the participants. Then there is a discussion of the participants' pre-college characteristics, preparation, social support, and financial support. The discussion continues with examining the participants' experiences becoming academically and socially integrated into the college's system after they began enrollment. Finally, the chapter examines the participants' goals and commitments to continue their educations.

\section{Institutional Background}

The Community College of Appalachia (CCA) is a medium sized, two-year state funded college located in a rural Appalachian Community with an enrollment of approximately 3,000 students (Carnegie Foundation for Teaching, 2009). In the mid-twentieth century, the state board of regents created a dual-campus community college out of what were formerly branch campuses of four-year state colleges. The board designated the new institution as a comprehensive community college responsible for programs of two or fewer years. In response to community requests, the college expanded to offer courses at a third site. In all, the college offers programs and courses in arts and sciences, career-technical education, developmental studies, and community service. The intent of the college is to admit all adults wishing to pursue postsecondary education.

The facility for the branch of the institution where the study took place is a single building within the business district of the community of approximately 6,000 in which it is located. All campus resources are offered within the single building. The building houses a campus bookstore, student service offices, such as financial aid and advising, and a student 
lounge and recreation center. The college is located in a rural region of the state with some industry and no other institutions of higher education.

The college describes its purpose as providing opportunities for postsecondary education to all regional residents and to be viewed as an educational resource center recognized as a community of learners who value integrity, mutual respect, a commitment to excellence, and community service. In addition, the college strives “...to develop a competent district workforce which can compete in a global economy, and to respond to cultural and civic interests and needs of the communities it serves" (CCA, 2009). The college's goals are to:

1. Be recognized as a place of educational opportunity, an instrument of personal and organizational change, and a catalyst for regional economic development;

2. Be responsive to educational needs of our region by being proactive, agile, and flexible with emphasis on partnerships;

3. Lead in using current technological tools to facilitate learning and improve productivity;

4. Link local strengths to global knowledge and opportunity;

5. Continue to value each individual, every culture, our heritage, and the natural resources upon which we depend; and

6. Provide an open environment and the necessary tools to foster growth and development of our community of learners (CCA, 2009).

In response to a state mandate, the college requires degree-seeking students complete testing in reading comprehension, writing skills, basic math skills, and elementary algebra. Although students not seeking a degree are not required to complete the same testing, once they enroll in a course with a Math or English prerequisite or change to a degree seeking status they 
are required to complete the testing. The college exempts students from the testing if they have completed college level Math or English or if they receive acceptable scores on standardized tests such as the ACT or SAT. The college uses the results of assessment tests to determine students' admission statuses. The status options for newly enrolled students are Developmental Students, Provisionally Accepted Students, or Matriculated into a program of study. The college assigns the students advisors and permits the students to select courses based upon their admission statuses. Students who do not receive an acceptable score or do not have the required $\mathrm{ACT} / \mathrm{SAT}$ are required to complete developmental courses in the subjects before enrolling in some college level courses. Students who require developmental courses in three or more areas are also required to enroll in a college success course their first semester. The college provides information to the public as well as to the students about the intent of developmental coursework in relation to developing students' skills, ensuring proper placement based upon each student's level of preparation, maintaining academic standards, enhancing retention of students, and promoting the cognitive and affective development of students.

\section{Study Participants}

I contacted the college requesting permission to conduct this study in addition to requesting assistance in identifying students classified as first-generation college students who had completed half of the requirements for their programs. An administrator from the college allowed me to conduct the study and offered to help make contact with students who met the study's criteria. The administrator worked with me to schedule my visit to campus. Once the administrator and I agreed on a schedule, he asked his staff to contact students they knew to be first-generation college students and ask if they would participate in the study. When students arrived to their meeting with me, I explained my study and confirmed they were willing to 
participate.

The participants of the study have an array of backgrounds and experiences. I interviewed 11 students, eight female and three male. They are all within the first generation of their family to attend college and ranged in age from 20 to 50 at the time of the study. Susan is a married mother of three who identified herself as Dominican and Hispanic and was 36 at the time of the study. Both of her parents earned GEDs. She had several siblings, one of whom dropped out of college after a year and two younger siblings who started attending community colleges. Margaret is a single White female who was 50 years old when she participated in the study. Her father dropped out of high school after the eighth grade and her mother did so after the tenth grade. Although she is one of several children, none of her siblings attended college. Dorothy, who was 21 at the time of the study, is a married White mother. Her mother left high school after her junior year. Dorothy believes her father attended college but does not know what he studied. Her older brother obtained technical training after high school and her younger sister plans to attend college to study nursing. Lisa is a White divorced mother of a teenage son who participated in the study when she was 45 years old. She believes her mother left school after tenth grade. Her father died when she was a teenager and she does not know his highest level of education. Both of Lisa's sisters had attended college and one was a registered nurse. Nancy is an Asian-American single mother who was 24 at the time of the study. Her mother completed high school and her father began college but dropped out. She has one brother who started college but dropped out when he started working. Karen, who was 32 at the time of the study, is a White married mother. Both of her parents earned high school diplomas. Betty is a White single student who was 28 at the time of the study. Both of her parents graduated high school and continued their training after high school although they never attempted additional formal 
education. Her brother earned a Bachelor's degree and her sister attended college for two and a half years before leaving school. Helen is a White, single mother who participated in the study when she was 25 years old. Her mother and father both graduated high school and her father continued receiving training through his job. Her brother began attending a technical school but she did not know if he earned a degree or not. Bob is a Hispanic male who lives with his parents. He was 20 years old at the time of the study. Both of his parents graduated high school and neither attended college. His younger sister is planning to attend college and is collecting college information packets. Dave is a married White father of three who works a full-time job in addition to attending college. He participated in the study when he was 30 years old. His parents are high school graduates with four sons, Dave being the only son to attend college. The final participant, Mike, is a White, single, immigrant from a post-Soviet western European country who was 44 when he participated in the study. His mother has the European equivalent of an Associate's degree and his father has trade school training from Europe although neither his mother's nor his father's credentials are recognized in the United States. Mike's stepsister earned a Bachelor's degree in Psychology.

\section{Pre-College Characteristics}

FGCS have a number of unique experiences that may impede their pursuit of a college degree. These experiences center round their academic preparation, support, and financial resources leading up to their entering college.

Academic preparation. The participants represent a variety of educational backgrounds. Some followed a traditional path to higher education and entered college directly from high school while others returned to school after several years. Karen, Bob, Dorothy, and Helen all entered college directly after graduating high school. Karen not only entered college after high 
school, but also continued her education to earn an Associate's degree. After working for several years, she returned to college to earn a second degree in an unrelated field. Bob and Dorothy both entered college directly after high school and continued their educations without a break. Although Helen entered college directly after high school, she attended college in a start and stop manner. Two of the other participants, Mike and Dave, sought advanced training after high school that did not involve attending college. Three more participants, Lisa, Nancy, and Betty, waited for several years after graduating high school to enter college. The final two participants, Susan and Margaret, earned their GEDs before entering college. Similar to FGCS described in other studies (Chen \& Carroll, 2005; Horn \& Nunez, 2000; Humphrey, 2000; Terenzini et al., 1996), regardless of the path they took to college, most of the participants were not prepared for the academic demands of college.

Karen is one of the participants who took a traditional route to college. She entered college and earned an Associate's degree in business after graduating high school. Once she earned the degree, she worked for several years in a business field. Not long before participating in the study, Karen decided to change careers and returned to college to earn a degree in a new field. Karen came from an academically strong high school that "pushed college" and believes she was prepared for the academic content of her courses. Even coming from an academically strong high school and already having earned a degree, Karen was not completely prepared for college when she began working on her second degree. Karen found she still did not fully understand what to expect from the college environment and struggled with time management. When asked about her biggest academic challenge she explained, "this time, it's time because you have children and... just time, time to get everything done."

Bob and Dorothy are two other participants who also followed traditional routes to 
college education. Both entered college directly after graduating high school. Although Bob believes he was academically prepared for college, his experiences demonstrate he was not prepared. Bob's experiences demonstrate he was not prepared for the academic content of his classes. Bob struggled with math but does not attribute those struggles to poor preparation. Instead, he attributes his struggles in math to not taking math his senior year in high school. Bob explained, "Whenever I was going to school, you only had to have math in your freshman, sophomore, and junior years." In addition to not being prepared for the academic content of his classes, Bob entered college without having a degree in mind. When asked directly if he would make the same decisions again, Bob said he would have decided on an academic program earlier in his college pursuits.

Although Dorothy reports coming from a high school that focused on preparing students for college, the descriptions she provided demonstrated she was not prepared for the college environment. When she entered college, Dorothy performed well on placement tests and was not required to take developmental or remedial classes. She says she found some of the content of her college courses to be a repeat of information from her high school classes. However, when she entered college she did not understand how the learning environment in college would differ from the environment she had encountered in high school. She explained, "In high school, they pretty much spoon fed you. Here, you have to learn how to be very self-motivated, selfdisciplined. That was the hardest thing for me to overcome, grade wise."

Helen initially followed a traditional route to college by enrolling in college after graduating high school. However, she left college for several years and returned to college shortly before participating in the study. Although Helen believes she was academically prepared for college, her experiences in the classroom demonstrate she was not prepared. When asked if 
she was prepared for the academic challenges of college, Helen said she was because she was able to talk to others about what to expect from the program. However upon further discussion, Helen described having difficulties with college level math which suggests she was not prepared for college.

Several of the other participants took non-traditional routes to seeking a college education. Mike, Dave, Lisa, Nancy, Betty, Margaret, and Susan all attended college in nontraditional manners. Mike followed a very non-traditional route to college. He received a great deal of training and worked in his field of interest for some time before moving to the United States. After arriving in the U.S., Mike discovered the training and certification he previously received was not recognized so he was not able to find employment in his field. He spent time reflecting on his situation and in the end he decided to enter college and earn the American degrees he needed to gain employment in his desired field. When asked about his opinion on his level of academic preparation, he responded he believed he was "over-prepared" as the result of his prior training, experience, and personal background. However, he also referenced having difficulty with English which suggests he may not have been fully prepared for college in the U.S. Based on the description of his experiences, he was prepared for the academic concepts he encountered in college but not for learning in an English-speaking environment.

Dave also followed a non-traditional route to seeking a college education. He entered the military after graduating high school and obtained a full-time job after his discharge. Dave scored very well on the placement tests and said he does not struggle with the academic content of his classes. However, Dave revealed he had to enroll in developmental math and repeat a math class so he must have had at least some struggle with the academic content. In addition, Dave was not prepared for college because he did not know what to expect from the college 
environment. He has difficulty balancing his job responsibilities with those of being a student. Because of time constraints related to his job, he frequently misses classes. He explained: I didn't plan on it being as hard as it is to be here to study. Most of my classes, I do everything on my own. Like I haven't been to my Comp 101 class for three weeks. So everything I'm researching myself. You know, you can call the instructor but it's kind of hard to explain to you over the phone.

Lisa graduated high school and spent several years working in her family business. Based on results from placement tests as well as her self-assessment, Lisa was not academically prepared for college. Lisa says she struggled with her initial composition class because she did not take an English composition class in high school. In addition, her placement test results indicated she was not ready for college-level math courses so she was required to take a developmental math class. When asked directly if she was academically prepared for college, Lisa said "Not really. It was quite a challenge at first. I've had to drop different times and then come back."

Nancy graduated from high school and entered the workforce directly thereafter. A few years later, she decided to enter college. Nancy believes that when she entered college she had the academic skills she needed to be successful. In spite of her self-assessment that she was prepared for college, her math placement scores were two points below that required for college level math and she was required to take developmental math. This experience demonstrates she was not prepared for college.

Betty also took a non-traditional road to college. She graduated high school and waited for nine years to attend college. Because of her high school grades and scores, the college did not require her to take placement tests. She began her college career by taking traditional college 
level courses. Betty says she was prepared for college and unlike those of her counterparts, her responses supported her self-assessment. She received As and Bs in her initial courses and did not have to take any remedial or developmental courses. In describing her college classes, Betty said, "Everything has been surprisingly easy."

Margaret and Susan both dropped out of school and earned their GEDs before attending college. Their educational backgrounds and descriptions of their experiences suggest they were not academically prepared for college. Margaret dropped out of high school and more than 30 years later entered college. Although she believes she was academically prepared for college, Margaret experienced a number of academic challenges that demonstrated she was not prepared for college. She earned poor scores in the math category of the GED and took multiple developmental classes at college. In spite of these challenges, Margaret believes she was prepared for college and attributed her lack of math skills to the fact that she had been out of school for more than 30 years.

In contrast, Susan recognizes she was not academically prepared for college. She dropped out of school and later earned a GED. She struggled through the math section when she took the GED test and received a low score that required her to re-take the test three times in order to pass the exam. Even after her experiences preparing for the GED, she struggled through the college's math requirements. Susan also describes a number of challenges balancing her family and work responsibilities with those of being a student. These experiences demonstrate she was not prepared for the academic environment she would encounter in college.

Financial resources. The financial resources FGCS have at their disposal also play a critical role in their success integrating into college. Without the financial resources they need to participate in the academic and social systems of the college, students are not able to 
academically and socially integrate into the college. Horn and Nunez (2000) reported FGCS are likely to have limited financial resources. Many of the experiences of the participants of the study support those findings however, others did not. Margaret, Mike, Bob, Lisa, Nancy, Helen, and Susan all describe access to limited financial resources, which supports Horn and Nunez's (2000) finding. However, Betty, Dorothy, Karen, and Dave reported they did not have any financial challenges; the experiences of these participants illustrate another aspect of the FGCS financial resource story.

Several of the participants provided supported Horn and Nunez's (2000) findings. For Margaret, Mike, Bob, Lisa, Nancy, Helen, and Susan their lack of financial resources served as a major hindrance to their quest for a college education. Margaret does not have an income and lives with her parents in order to reduce costs. Mike does not have a paid job and has limited access to financial aid because of his citizenship status. Because he is not a U.S. citizen, the major source of financial aid available to him is loans. He is an independent student who relies on loans, an occasional scholarship, and obtaining odd jobs to earn the money he needs to attend college and cover living expenses. Bob discovered when he was in high school that the combination of the financial aid he would receive and the amount of money his parents could contribute would not cover the costs associated with attending his college of choice and would limit his ability to seek his preferred degree. As a result, Bob had to make other choices that led to his attending CCA and studying the programs he entered. He explained, "I had to settle for something a little less for now."

When Lisa first started college, she relied on her husband's income to pay for classes as she took them. After her divorce, her income fell to approximately $\$ 11,500$ per year. Within that limited income, she raises two children and commutes 30 miles to and from the college in order 
to seek a college education. Although Nancy's father occasionally provides a small amount of financial help and she receives child support, she relies primarily on her own efforts to obtain the money she needs to raise her son and attend college. The first time Helen attempted college, her parents helped pay for it. At the time of the study during her second attempt, Helen depends upon financial aid to pay for her college expenses. Susan depends upon her spouse's income to pay for her college expenses. She described her financial situation as "very stressful. Each of these participants explained that without access to financial aid, they would not have been able to attempt a college education.

Other participants described different pictures of FGCS' financial resources. Betty, Karen, Dorothy, and Dave each reported they did not have financial challenges. The experiences Betty and Karen describe diverged from the experiences of FGCS Horn and Nunez described in their study. Betty explained she worked 10-15 hours a week and lived with her fiancé who had a good paying job. Their combined household income ranged between $\$ 60,000$ and $\$ 70,000$ per year. Because of their financial circumstances, she faced few financial challenges. Karen and her husband had recently sold a business and she was able to rely upon the proceeds of that sale and a household income of $\$ 60,000$ per year to attend college. As a result, she did not have any financial concerns.

Dorothy and Dave report they do not have any financial challenges related to attending college but their experiences suggest otherwise. Dorothy's household income is approximately $\$ 45,000$ per year. Although she says she does not have any financial concerns, during the interview she revealed she received financial aid through grants and scholarships to help pay for college. Her being able to access these funds suggest Dorothy has limited personal financial resources. Although Dave reports he does not have any financial challenges related to attending 
college that was not always the case. When Dave finished high school, his parents could not afford to pay for him to attend college. As a result, he entered the military. By the time he decided to enter college, he was able to rely on the G.I. Bill he had paid into and worked a fulltime job. The combination of these two resources makes it possible for him to attend college. The participants' reliance on financial aid programs suggests if those programs were not available, they would not be able to attend college.

Social support. According to Tinto (1993), the support students receive plays a critical role in forming their goals of seeking college educations. Horn and Nunez (2000) reported FGCS are often not encouraged to attend college from a young age as their non-FGCS counterparts are. The experiences of the participants support that finding. Although most of the participants were encouraged at some point to attend college, only two of the participants were encouraged to attend college before they were adults.

Dorothy and Karen were the only two participants who were encouraged from a young age to attend college. The encouragement they describe is inconsistent with the findings of Horn and Nunez (2000). Dorothy was encouraged to attend college by multiple people and that encouragement started when she was young. By the time she reached the $8^{\text {th }}$ grade, her mother and grandmother began pushing her to attend college. They frequently reminded her that she needed to do well in high school for college admission. Dorothy received further encouragement when she reached high school. Her teachers and advisors encouraged her to attend college. On a systematic basis, Dorothy's high school offered a class on how to plan for and select a college and provided approved absences from school in order to visit colleges. Unlike many other FGCS, Dorothy benefited from support from family and acquaintances to attend college as well as support from her educational system in high school to attend college. 
Karen was the second participant of this study who was encouraged from young age to attend college. Karen's mother encouraged her to attend college for most of her life. She explained, "It was just always I was going to go. Like I am with my eight year old, she knows that she's going and it's always been that way."

The six other participants who were encouraged to attend college in some manner did not receive that encouragement until after they were adults. For some participants, family members were their major source of encouragement but for others, their encouragement came from friends and community members. Family members encouraged Susan, Betty, Helen, and Bob while friends and community members encouraged Lisa, Bob, and Dave to attend college after they were adults.

For many of the participants who were encouraged as adults to attend college, family members including significant others served as major sources of encouragement. Susan's husband encouraged her to attend college for five or six years before she finally entered. She explained she delayed her entry because "I kinda doubted myself." As she started preparing for college, he tried to advise her on what to expect from college classes and how to prepare to be successful in college.

Although Betty's parents encouraged her to attend college after she graduated high school, she did not do so until her fiancé encouraged her to do so nine years later. He used her desire for an engagement ring as motivation to complete her first semester. She explained her fiancé knew she was interested in attending college and "he just knows that I can do better and pushed it and pushed it and said I'd finally get the ring with a report card."

The first time Helen attempted college, she enrolled because most of her friends were attending college so she thought she should do so also, not because anyone encouraged her to do 
so. For her second attempt, Helen's fiancé knew she wanted to attend college and encouraged her to follow her interests. She explained, "I had talked about it and he said if you want to go, you need to go."

After she was an adult, one of Lisa's friends was the first to encourage her to attend college. That had occurred only a few years prior to participating in the study. Other than the encouragement of that friend, Lisa did not report any other source of encouragement to begin college.

While Bob was in high school, a high school advisor encouraged him to attend college. After high school, one of the staff from the college encouraged him. Although Bob referenced his parents in relation to his attending college, he did not perceive his parents as encouraging. His perception was that his parents were warning him that he either attended college or moved out on his own and supported himself.

Dave was not actively encouraged to attend college at any point. His experiences and the people around him is what provided him the encouragement he needed to attend college. Dave joined the military after graduating high school and his experiences there led to his desire to attend college. He explained:

The schooling there that I went through, you learn something every day, so they kind of drilled that into your head and then some of the guys I knew were going to school or had been in school or were going to go when they got out, and talked about it a lot.

The remaining three participants did not report receiving any encouragement at any point to attend college. When directly asked who first encouraged them to attend college, both Nancy and Margaret reported they did not receive any encouragement to attend college. When asked the same question, Mike described not being encouraged to attend college as well as being actively 
discouraged from attending college. He reported most of his family and friends questioned why he would attend college. They believed since his European experience and credentials would not allow him to work in the same field in the United States, he should get a job in another area that would not require additional training or education. When asked directly if any family or friends had questioned his decision to attend college, Mike responded, "Well yeah, pretty much everybody. 'Why do you need it? Why don't you just go get a job?'”

Goals and intentions. Van T. Bui (2002) reported FGCS have a wide variety of reasons for entering college. The participants of this study were no different. They provided several reasons for enrolling in college which included increasing their job opportunities, setting positive examples, achieving personal goals, exploring their career options, and re-entering a field in which they had already worked. In spite of the variety of reasons the participants had for entering college, the two most common reasons these participants provided included a desire to improve job opportunities and to achieve personal goals.

One major reason the participants provided for attending college was to increase their employment opportunities and obtain better jobs than they would be able to obtain with high school degrees or GEDs. Betty explained she enrolled in college because, "You can’t find a job in [the region] without an education." Bob explained his reason for attending college was to "get a better job." Margaret considered entering college after she earned her GED. She explained, "I wanted to get a better job. That's basically it. I went and got my GED and got scholarships and thought I might as well check into it." Nancy described being dissatisfied with her previous job and wanting to find a better one. She explained, "I lived out in the real world and I realized at an early age that I don't wanna be flipping burgers when I'm 40 years old.” Helen explained, “I didn't want to have to, me and my son, just barely make it by" financially. Dave explained he 
wanted to be able to use a college education to "get a decent job."

Nancy's experiences prior to entering college led to her desire for a college education. She recognized that without a college education, her options were very limited. She worked for several years at a low paying job where she had a difficult time earning enough money to pay for basic living expenses. Nancy explained:

I lived out in the real world and I realized at an early age that I don't wanna be flipping burgers when I'm 40 years old. I wanted to do something and plus I got pregnant. I had my son and it motivated me more to really do it.

With that renewed motivation, Nancy decided to go after a college education to expand her career options and provide a better quality of life for her family. She explained:

I just didn't want my son to struggle as much as we did. I also wanted to be able to provide things he needed, but he'd have to work for it, and he's not gonna get it handed to him. But I just want him to have that security. In order to be able to make sure that he gets the stuff that he needs.

Participants believed better jobs would allow them to provide a higher quality of life for themselves and their children. Helen decided to re-enter college in order to provide a better life for herself and her son. She worked at a local supermarket and struggled to earn enough money to pay all of her bills. When she entered college, she knew she "wanted to do something health wise" but chose her specific major based on the area in which she would most help others. In her first attempt at college, she studied in a radiology program but for her second attempt, she chose to enter a respiratory therapy program.

Dave worked full-time at a local factory after leaving the military. Although he was paid well in his job, he wanted to make sure his children had more opportunities when they grew up 
than he had at his disposal. Dave began college because he wanted to set a positive example for his children. His wife had earned a degree and he wanted his children to see both parents had college degrees. He also said he hoped the fact both parents had college degrees would increase the possibilities for his children. He explained:

My wife has a degree and plus my kids, when they get a little older, they can say 'Hey, my parents, both of my parents have degrees; they have decent jobs.' Maybe they'll go into that instead of like going into the military like I had to do to get the money to get a decent job. Open the door a little for them I guess.

The second major reason the participants named for enrolling in college was related to their personal goals. Dorothy, Karen, Lisa, Susan, and Mike all reported their desire to achieve personal goals was a reason for them attending college. Their goals ranged from specific career paths to generally improving their knowledge base. When asked why she decided to attend college, Dorothy explained, "It's just the right thing to do pretty much. You can't make anything of yourself if you don't. I've always wanted to go to school. Kinda like I never really thought about not going."

Karen entered college directly after high school and earned a degree. However, after working several years in a business field, life and family events convinced Karen to change to a different career. She wanted to have a career that she felt was more rewarding than her previous career had been and where she could be of more help to others than she had been. When asked what made her decide to re-enter college for a degree that was vastly different from her initial degree, she explained, "I had intentionally wanted to go into education but things just sort of led me this way, health issues with people in my family and different issues in hospitals and I just kind of switched." 
Lisa had worked at a family business for many years. She decided to enter college for a sense of accomplishment from a paid job and to provide financially for her family. In general, she wanted to increase her level of education and to do something she enjoyed. She explained:

For 18 years, we owned our own business, and I never wrote myself a paycheck for 18 years. So now, I want a paycheck again. I want to be able to stand on my own two feet and to support my kids and not to worry financially about bills and things that they need. Susan decided to enter college to make a change in her life and provide for her children. She dropped out of school and later earned a GED. She had been a stay at home mom with her children until they were old enough for her to feel comfortable attending college. She entered college to make a change in her life and prove to herself that she could do it. She explained:

[I] just realized that I wanted to change my life and just be able to provide for my children and also for myself as a person. I have many roles of course but just for me as a person, I just I felt that this is what I need to do for myself; to be complete and to feel that I can do it because I also dropped out of high school and got my GED. Mike's path to entering college was much different from the paths of the other participants. He had attended a military command college and worked in the technical aspect of police investigations for a number of years before moving to the United States. After arriving in the country, he discovered his training and experience was not recognized and he could not work in his field. After a great deal of thought, he decided to obtain the American degrees that would allow him to continue in his field of choice. When asked why he decided to attend college, Mike explained:

Because my European one was not nationally accredited. All college credits were not transferable because they were 10 or more years old. And after two years of thinking 
about it and letting my ego go, I decided I would do it all over again.

\section{Post-College Entry}

After beginning college, students face a number of roadblocks before they successfully graduate. Tinto's (1975) model describes the importance of students being integrated into the academic and social systems of a college to their success. He further explained that when students are successfully integrated into college, their commitments to college and intentions to complete their educations influence their decisions to continue through to graduation or to depart the college. The participants of the study discussed their experiences with the academic and social systems of their college in addition to their financial resources, goals, and commitments. These aspects all influence students' abilities to be academically and socially integrated into a college.

Academic involvement and integration. After students enter college, the extent to which they are academically integrated into the college influences their potential completion of a degree (Tinto, 1975). Students who are academically integrated find a match between their skills, interests, and needs with the academic characteristics demanded by the college. Students who find that match are more likely to persist in their education. Students' academic performance and positive interactions with faculty and staff enhance their perception of a match.

Academic Challenges. The academic preparation students have before entering college is a critical component of their classroom experiences once they begin college (Nora, Attinasi, \& Matonak, 1990) and their ability to meet the academic demands of their classes. Colleges often expect students to begin with basic academic skills. However, that is not always the case for FGCS (Fallon, 1997). In addition, FGCS often do not have informal exposure to higher education (Fallon, 1997) where they learn to navigate the higher education environment. 
Students who are not prepared for college often have difficulties in their classes and in managing the college environment and as a result may not find a fit between their skills and interests with those expected by the college. Academic preparation served as a challenging area for many of the participants of this study. Participants illustrated their poor preparation for the academic demands of college through references to placement in developmental courses, and difficulties in college level classes. Many of the participants described not having a basic understanding of the demands of college classes and the academic environments they would encounter in college when they first entered college.

When asked to about their academic challenges, the participants most frequently described lacking academic abilities and understanding how to function in the college environment. Their experiences support the findings of Van T. Bui (2002) which reported FGCS are less prepared for college. In spite of referring to challenges, the participants seldom referenced poor preparation through their prior educational experiences or lack of assistance in learning the skills at CCA. Instead, the participants often attributed their academic difficulties to their own inadequacies and attempts to juggle the demands of their lives.

Susan attributed her academic challenges to poor skills in specific subjects as well as her attempt to juggle too many responsibilities. She supported the Humphrey's (2002) reports that FGCS often rate their math skills as lower than average. She said, "It's always been challenging for me." However, her academic difficulties did not end with math. Even though Susan reported she was prepared for other subjects, she also revealed having difficulties in Anatomy. In addition, Susan believed a portion of her academic difficulties were the result of taking on too many responsibilities as Fallon (1997) discussed. She explained, “I don’t know what I was thinking, to pick up four classes and then work." 
Another participant, Helen, also described one of her biggest academic challenges as meeting the college's math requirements. She also attributed her challenges to her own lack of skills in the subject matter not to poor preparation. She explained math was a difficult concept for her to understand in general. In conflict with research that FGCS do not have informal exposure to higher education (Fallon, 1997), Helen described various people in her life informing her of what to expect from her college program.

Although Betty described having very few academic challenges in college, she was not prepared for the college environment. Because she did not know what to expect from the academic program, other people convinced her she would not be successful in the radiation program she wanted to study. Betty suggested faculty and administrators, "be supportive and encouraging" to FGCS because, "anything could deter them from going to college. Let them know what to expect from college. Students need to know who to ask questions when picking a major."

Karen was not prepared for college either time she attended. When she enrolled in her first degree program, Karen believed she was academically prepared but not prepared for the college environment. She was "not motivated" and was not interested in her classes. While she may have been more motivated and interested the second time, Karen still was not prepared. The second time she enrolled, Karen found time management to be her biggest academic challenge. She explained, "it's time because you have children and... just time, time to get everything done." This demonstrates a lack of preparation for the academic environment even though she had already earned one degree from the same college.

Nancy described various academic challenges. Like other participants, she had difficulties in her math classes. Nevertheless, she like the others did not blame her difficulties on 
poor preparation. Instead, she attributed it to her own lack of skills. In spite of her problems with math, Nancy believed her biggest challenge came from not knowing what to expect from the college environment. She was accustomed to professors giving her a step by step of what would be on tests. The semester she participated in the study, she encountered a professor she described as "completely different." Nancy explained:

She gives you objectives and she's like, if you know this stuff, which it's a lot. It's not, describe photosynthesis step by step. It's not pinpointing exactly what it's going to be on photosynthesis, which steps. So she just gives you an overview. You actually have to study it, know it.

Dave was prepared neither for the academic demands of college nor for the college environment. He reported enrolling in developmental math because he was not prepared for college-level math courses. Even after taking developmental math, Dave struggled in later math classes. Although he described struggling to meet the college's math requirements, the most educationally critical challenge he described was attending class. Because he worked a full-time job, he struggled to balance his family and work responsibilities with those of attending college. As a result of conflicts with his work schedule, he had not been to one of his classes for three weeks. He explained, "I guess I didn't plan on it being as hard as it is to be here to study." In spite of referencing multiple challenges, Dave did not refer to his difficulties as a matter of poor preparation. Instead, he attributed his difficulties to having poor skills in math and concurred with Fallon's (1997) findings by attributing his difficulties to missing a high number of classes due to his work schedule.

Lisa not only was not prepared for the academic demands of college but also was not prepared for the environment of college. Lisa described herself as having poor writing skills and 
struggling to stay on topic when writing research papers. Her difficulties with English influenced her performance in math classes. She described trying to complete math story problems as a "nightmare." In addition, she also struggled to adjust to the college environment. Lisa said some of her biggest challenges were related to the use of technology in her classes and juggling the demands on her time. She explained, "Not knowing how to use a computer or a calculator. We didn't have computers, but we also weren't allowed to use calculators, or we got an F. I guess it's a new way of life". In addition, her experiences supported Fallon's (1997) reports and struggled to balance the demands of being a student with her family responsibilities saying, "Your time is more demanded, and I have two children, so I had to try to schedule my school schedule around them.”

Bob also was not prepared for the academic demands of college or the college environment. Although he believed he was academically prepared for college, his experiences demonstrated he was not. He reported struggling in his math classes. He explained:

I had the Algebra, and I was fresh out of high school when I took that. It was way different from what I had in high school. I had to get used to getting the pace of that; had to listen a lot more; trying to figure things out on my own every now and then.

When asked to describe his biggest academic challenges, Bob said "homework and understanding class." He struggled to adjust to being a self-directed learner and needing to learn at a faster pace than he had in high school. Dave explained, "We were supposed to make an employment contract, but didn't know how. So I had to get online, research how to make one."

Dorothy's biggest academic challenge developed from her lack of understanding of the college environment. Although she found the classes easy and was already familiar with much of the content, she had difficulty adjusting to the environment of college. She was accustomed to 
being strictly guided through learning. She explained:

In high school, they pretty much spoon fed you. Here, you have to learn how to be very self-motivated, self-disciplined and that was the hardest thing for me to overcome, grade wise. Because if you're not self-disciplined, you don't usually make the greatest grades.

Academic assistance resources. The majority of the participants described having difficulties with the academic content of their classes. For those students who do not begin college with the academic skills they need to be successful, they must acquire them through other means. Unlike reports by Damashek (2003) that reported students who are failing are unlikely to seek out assistance, the participants of this study sought assistance. However, they reported using a limited variety of resources. The resources the participants used included campus resources, family assistance, and taking beginner coursework. The participants not only sought assistance from these resources but each described being successful at receiving the help they needed.

Campus resources were one set of academic support for the participants. They sought help from faculty, peers, and the tutoring center with the tutoring center and the college's faculty being the primary campus sources of assistance when the participants lacked the skills necessary to be successful. Although participants described using campus resources quite often, the specific resources they used varied from one person to the next. The tutoring center and college's faculty were the primary campus sources of assistance for the participants when they lacked the skills necessary to be successful. The participants all described the faculty and staff of the college as helpful and concerned about students' success.

In spite of the general variety of resources at the participants' disposal, the most resources any one participant used was three and several of the participants sought assistance from only one source. Susan, Helen, Dave, Betty, Margaret, Nancy, and Mike each referred to 
using only one academic resource. Karen and Lisa each sought academic assistance from two campus resources. Bob and Dorothy used the widest variety of campus resources for academic assistance. They each sought help from three sources.

As well as seeking assistance from a variety of resources, the ways these resources helped the participants also varied. Bob used the tutoring center, classmates, and instructors for assistance when he had academic difficulties. He found the tutoring center helpful because the people working there were usually more experienced students who had completed the class previously. They helped him by giving him detailed explanations of the material and reexplaining it from a student perspective. Bob explained he had limited success in obtaining help from classmates. He found classmates often confused him more. When he had more severe problems understanding the material, he asked faculty for help. Faculty helped by re-explaining the material and providing more detailed instructions than they had in class.

Dorothy also described using multiple resources when she had difficulties in class. She used the tutoring center, classmates, and instructors. She found the tutoring center helpful because they offered workshops where the tutor or instructor provided supplemental instruction and individual tutoring sessions. Going to classmates was a benefit to Dorothy because she studied with them in a group. They worked together to form study guides and discuss coursework. The third source of academic assistance for Dorothy was the instructors themselves. She found going to them helpful because they re-explained the material, presented the material in a different manner, and gave extra assignments to help her learn the material.

Karen made use of few resources when she had academic difficulties. She used an inclass supplemental instructor available in her science classes and the tutoring center. The supplemental instructor re-explained the material and helped with the technology aspect of 
solving problems for the class. Karen found the tutoring center helpful because it helped her review for classes and taught her new methods to remember the material she was covering in her class.

Mike found very few resources useful when he had academic difficulties. He explained he preferred to try to figure problems out on his own or discuss problems with his instructor. He found instructors helpful because they re-explained the material or explained it in a different manner. He did not like to work with classmates because he had experienced group projects where not all of the group members participated for the final project.

Betty preferred to seek help from instructors when she had academic difficulties. She explained the instructors reviewed the material with her and provided extra assignments to help her learn the material. Although she referred to seeking help from faculty, she also explained she rarely did so. In this aspect, her reports concur with Damashek's (2003) findings that student who are failing are not likely to seek help.

Lisa seldom used many resources when she experienced academic difficulties. Her major source of assistance came from the tutoring center. The tutoring center helped her learn how to use technology to solve problems and how to structure problems so she could find the answer. She explained she had asked her instructor for help once in a telecom class. When asked about seeking help from classmates, she explained, "I learn on my own better... because if I get in a group where people are going over stuff we're going to have on a test and everybody has a different kind of answer; that gets totally confusing."

Margaret described very limited access to resources to help her with academic difficulties. When she had difficulties in her classes, Margaret went to the instructors and a tutor. She believed the professors gave her clarification on the assignment. The tutors helped clarify 
the material and helped her learn.

The only resources Nancy referenced using when she had academic difficulties were faculty and classmates. Of the two, her biggest source of academic assistance was classmates. While she found faculty members helpful, she did not believe she had enough time to seek help from them. However, she described being very successful at working with classmates to resolve academic difficulties. She explained:

We got our notes and we just sit down and we review it. We review it together and then we review it by ourselves, and then we had my dad test us. He asked me and her. We made a game out of it. We wrote down our answers to see who got more points and stuff. We just make it fun. And we learn it better I think.

Dave used very limited resources when he had academic difficulties. The only resource he reported using was the tutoring center. He believed some of the faculty were so intelligent they could not teach the material. As a result, he said he "actually felt dumber" when he left the class. However, when he sought assistance from the tutoring center, they would re-explain the material so he would understand it better.

The only resource Susan sought when she had academic difficulties was the tutoring center. The tutoring center had someone serving as a tutor who was a professional in the field. When he provided tutoring, he re-explained the material in a step-by-step manner and sometimes provided a different technique for the same procedures. Susan explained his approach was helpful because she did not feel uncomfortable asking him to repeat information as she did in class.

Helen referred to seeking help from only two sources. Her primary resource was her instructors. Her instructors re-explained the material and gave her pointers on what to study so 
she would learn the material better. Helen was the only participant who referred to seeking help from outside the college. Her grandmother had worked in the field Helen was studying so Helen sometimes asked her grandmother for assistance on things such as field specific terminology.

Like many other students who are unprepared for college, the participants of this study frequently referenced taking remedial or developmental courses or repeating courses (Horn \& Berger, 2004; Kazis \& Liebowitz, 2003), both of which demonstrates a lack of academic preparation for college-level study. The courses the participants referred to having problems in most often were English and Math.

Developmental coursework. When students enter college without the skills they need to be successful, they sometimes enroll in developmental or remedial coursework to learn the skills they need (Horn \& Berger, 2004; Kazis \& Liebowitz, 2003). The participants reported they took developmental coursework because they either made the decision to do so regardless of their placement test results or their scores on the placement tests reflected a need to take courses to prepare them. Two participants, Mike and Nancy, chose to enroll in lower level courses than their placement tests indicated was necessary based on their own assessment of their skills. Mike explained he took a developmental course to test his skills and ensure he was ready for college level work. Nancy chose to enroll in developmental math although she had the opportunity to retake the placement test. She explained:

I missed the test by like two points and she told me I could re-take it because I hadn't been in school for four years. I told her no, I'd rather just take it. If I missed it by two points even though it's just two points, I would want to kind of get it back into my head before I got into Algebra.

Other participants were directed to take developmental courses because of their scores on 
placement tests. The most common developmental courses for the participants of this study were math related courses. Lisa, Dave, Helen, Susan, and Margaret all enrolled in developmental math classes. Based on her placement test scores, Lisa enrolled in developmental math. Dave explained he took an introduction to Algebra course, which was a developmental class, and performed well in the class. However, when he enrolled in the next level class he struggled with the content and had to take it twice. Helen and Susan both enrolled in beginner Math to prepare them for their majors. Margaret was a participant who was required to take multiple developmental courses. At the time of the study, she was enrolled in her third developmental math course. The experiences of these participants concurred with Duggan's (2001) reports that FGCS often take developmental classes.

Interaction with faculty, staff, and administrators. Students' satisfaction with their opportunities to interact with faculty has a positive effect on their retention and success (Graunke \& Woosley, 2005). Students who are more satisfied are more likely to be committed to an institution or a program and according to Tinto (1975), more likely to persist. As a whole, the participants of the study seldom had out of class interactions with the faculty. Although Susan referred to the instructors at the college as her "friends", she did not interact with them out of a classroom setting on a frequent basis. Nancy described having out of class interactions with only one faculty member. With the exception of one or two of the faculty who she encountered in the community and said "hi and that's about it." Dorothy almost never interacted with faculty out of class. Betty, Karen, and Dave all reported they did not interact with faculty out of a classroom setting. Dave explained:

[I] really never interact with them outside. Like I'm taking music appreciation, I mean I do the book then he has a web-site that you can go to and you can take tests on-line. And 
then you e-mail them to him. And just for practice, for learning, I guess. But other than that, none of them I would say.

Even those participants who referenced interacting with faculty more often did not always have the same type of interaction with them. Helen explained she interacted with the faculty out of a classroom setting on a regular basis. However, with more discussion she explained her interactions were the result of her job where she would interact with faculty in casual greetings. Lisa described having frequent out of class interactions with faculty members. She said she asked questions when she had them and sought out instructors when she had questions about her grades. Margaret explained her out of class interactions with faculty varied depending on the class and assignment. However, the interactions she did reference related to specific assignments "other than if we pass in the hallway, we say hi." Bob and Mike were the two participants who referenced the most variety in the types of interactions they had with faculty. Bob explained he interacted with faculty on a frequent basis. He explained he talked with faculty out of class at least two days a week. Mike enjoyed having discussions with his faculty. He explained he had discussions with his instructors "whenever it is possible. Even if I can take them out for coffee and discuss it further, I do that too." Other than occasional casual greetings, most of the participants' out of class interactions with faculty members were limited to academic topics and focused on specific coursework.

The participants seldom reported interacting with staff and administrators at the college. A few of the participants' interactions with staff and administrators centered on school-related concerns. However, most of the participants' interactions with staff and administrators were casual greetings. Susan, who worked at the college, had dinner a few times with fellow staff members but did not interact with administrators. Helen reported exchanging casual greetings 
with staff when she saw them as a part of her job at a supermarket. Although Mike and Bob both referenced frequent interactions with staff and administrators, those conversations typically were focused on solving a problem or for a casual greeting. In spite of their limited out of class interactions with faculty, staff, and administrators, the participants did not report feeling uncomfortable with the interactions. Dorothy explained she typically only saw staff and administrators on campus and she usually had a student/staff relationship with them. She talked to them daily on a social level because "they're all fun people."

Based on their responses, most of the participants demonstrated they were integrated into the academic system of the college. Each of the participants described being academically successful and committed to their programs. Other than basic college level preparation, the participants described being successful in their courses. The frequency of the participants seeking help from the faculty and tutoring center demonstrated their comfort with the academic climate of the college. The two participants who demonstrated the least integration into the academic system were Dave and Margaret. Dave found it difficult to be on campus for classes and often relied on himself to learn class content. Margaret repeatedly struggled in her math content classes but was an Accounting major. This disconnect points at the possibility that Margaret's skills were not well matched for her program of study.

Attribution of success. The participants attributed their academic accesses to a combination of personal characteristics and support from others. The personal characteristics they referenced included determination, hard work and self-confidence. Susan attributed her success to a combination of her determination, her belief in herself, her desire to earn a college education, and the support of her family. Betty believed her dedication and patience along with putting "full-effort" into her schoolwork resulted in her success. Dave attributed his success to 
his own efforts. He explained with the many demands in his life; working a full-time job that required working rotating shifts, being married, and having children; it would be easier for him to quite college. Mike decided he succeeded through his own "stubbornness" and “determination." Dorothy believed her success could be attributed to a combination of her selfmotivation as well as the support of faculty and friends. She explained the teachers almost "treat you like you're their kid or something. They push you." Margaret attributed her success in part to having good study habits but also "the good teachers, and their wanting the students to achieve." Helen attributed her success to the support she received as well as her newly found academic focus. Lisa attributed her success in college to the motivation she gained after her divorce. Lisa explained, since her divorce "I want a paycheck again. I want to be able to stand on my own two feet and to support my kids and not to worry financially about bills and things that they need." Nancy believed her son was a major factor in her success. In general, she explained, "he pushes me, he just motivates me." Specifically, she believed that without her son "I'd be scared to see where I was because if I didn't have my son I don't know if I even would be at college. I don't know where I'd be at mentally like with responsibility, he just helps me be this person that I am." Karen was the only participant who attributed her success entirely to others. She attributed her success to the faculty, staff and students at the college. She explained, "Teachers are knowledgeable and you just get encouraged to keep going. The students, we have study groups together and different classes and that's helped too."

Social involvement and integration. Tinto (1993) identified social integration as a second area critical to student persistence in college. According to (Joseph, 1995) a significant component of students' persistence in college is the degree to which they are integrated into the social system of the college. For the purposes of this study, students' comfort level on campus, 
reported social challenges, and amount of out of class interaction with peers expressed their degree of social integration.

Comfort level. All of the participants in the study reported feeling comfortable on the campus. They attributed their comfort to the environment of the college. Dorothy explained, “There's always someone here to talk to. Usually everybody's in high spirits. They have so many activities for the students that it... gives you a break." When she first started attending the college, Lisa described herself as "a nervous wreck." However, by the time of the study, Lisa said she enjoyed going to the campus. Helen described the college as an environment she liked because of the small size of the. She explained, "It's small and there's a lot of one-on-one; like if you need help from the teachers and everything."

Susan, Betty, Karen, Mike, Bob, and Dorothy all explained they felt "very comfortable" on the campus. Bob reported, "If you need to talk to someone, you can. Everyone knows you by your name." Nancy and Dave both explained they were "pretty comfortable" on the campus. Dave described the staff as very approachable and helpful. He explained, "You can go to them and ask them anything. As long as they're here, you can ask them anything and they'll tell you."

Social challenges. The number of challenges participants experienced also suggested their degree of social integration. The participants typically said they did not have any social challenges related to attending college. They attributed their lack of social challenges to different aspects of their experiences. Some participants credited personal characteristics for their not having social challenges while others attributed their lack of challenges to characteristics of the college or a combination of the two.

Susan, Betty, and Dorothy all attributed their lack of challenges to characteristics about themselves. Susan believed she did not have challenges on campus at least in part because she 
was comfortable with herself. Betty explained she also did not have challenges on the campus. She explained, "It takes a few weeks I guess, each semester to kind of warm up and learn some people's names but then if I have a question, I'll even ask students.” Dorothy said she did not have any social challenges. She explained, “I don't really have any social issues. I'm not afraid to talk to anybody." However, she noticed, "the new students are just really shy. They need someone to reach out to them and say hey I'll help you." She often took it upon herself to be that person. Karen attributed her lack of challenges to the environment of the college. She explained the number of students her own age resulted in her not having social challenges on the campus. Helen attributed her lack of challenges to herself as well as the college. As for herself, she explained that she does not have a hard time meeting new people. However, she also said because the college was small, "everybody knows everybody." She believed the size of the institution led to fewer social challenges than she would have experienced at a larger university.

Mike and Dave were two participants who referenced having social challenges related to attending college. Mike said he felt a separation between himself and other students because of his age and his international status. This divide limited his interactions with other students. Although Dave originally said he was comfortable on the campus, he revealed when it came to social challenges, he had some struggles. He found it difficult to get to know other students and socialize with them regularly because when he did so, it took away time he believed he should spend with his family. At times, Dave felt isolated in his pursuit of a college education. When asked to describe any social challenges he had experienced, he explained:

If you don't know anybody, you really don't know what you're getting into, so when you go to class, it's hard for you, especially for me, I've got a family, it's hard for me to say hey, come on over, you know, we'll study together or whatever. I can't do that, I mean I 
could but then I'm taking away [from his family].

Interaction with peers. Regardless of their reports of being comfortable on campus and not having social challenges, Susan, Betty, and Karen did not interact with their fellow students outside of class. Susan talked to other students while she was in class but did not frequently interact with them out of class. The only out of class interactions with fellow students Susan referenced were those related to students buying puppies from her a couple of times a year. She expounded on this thought and said, "I'm just too busy. I don't have time to associate outside." Betty explained, "I come in and do my thing, and then go." Karen simply said she did not interact with students out of the classroom.

Five of the participants, Margaret, Lisa, Dave, Nancy, and Helen described limited interactions with their fellow students. Margaret interacted with her fellow students out of class twice a week for a study group. Dave explained he was friends with another student with whom he played cards. However, his friendship with that person preceded their status as students. Nancy described very limited interactions with other students. She described interacting with two people outside of classes. Helen interacted with other students outside of class on a daily basis. She worked at a local supercenter and encountered students there. Some students were coworkers while other students were customers. Her interactions typically focused on updating each other on how classes were going.

Three of the participants, Dorothy, Bob, and Mike described frequent interactions with their fellow students other than in class settings. Dorothy explained she had a group of friends that she spent time with away from school. That group of friends consisted of students as well as other members of the local community. She would occasionally see other students working around the community. Bob described interacting frequently with others on campus. He was on 
campus most days of the week and spent time between classes socializing or working in the tutoring center. Mike was very involved with the campus. He explained he interacted out of class with other students several times a week. He said, "I just love talking and sharing experiences."

The participants' lack of involvement in student organizations and activities further demonstrated their lack of out of class interactions with other students. Several of the participants were not involved in any student organizations and did not attend any activities planned for students. Margaret, Lisa, Helen, and Susan did not belong to any student organizations. With the exception of Susan, they also did not participate in activities. Helen did not believe with the demands of her academic program that she was able to belong to student organizations or participate in student activities. She explained, “There's not a lot of spare time now. We have to volunteer [and] do community service once you're in the program." While Susan had been unsuccessful in participating in student organizations, she had limited involvement in student activities. She attempted to serve on the college's student government board for one semester but resigned because she did not devote enough time to it. Although no longer involved in the board, she explained she tried to help with any activities that were occurring at the college.

Other participants described limited involvement in student organizations and activities. Betty belonged to an honors scholarship organization for two-year colleges and programs. Although she was not involved in campus activities, Betty explained, "I do lots of stuff outside." Karen did not belong to any student organizations or participate in any activities. She explained her focus for being at college was to obtain her education. Dave had been a part of the student governing board but was asked to resign from the position because he missed many meetings and activities. The only student activities he described attending were intermural sports games. Even 
though he took part in the games, he did not know his teammates. Nancy said she did not participate in any student activities. The only student organization she described being a part of was the academic honor society for two year colleges and programs. The only student organization in which Dorothy was involved was the campus programming board. She explained, "The Dean pushed me to be in that because I'm always volunteering for certain activities."

Only two of the participants, Bob and Mike, described being very involved in the campus community. In addition to being a member of the honors scholarship organization for two-year colleges and programs, Bob also was a student government board member and a member of the campus programming board. As a part of these organizations, Bob was involved in activities for the campus and community. Mike was also very involved in student activities and organizations. When asked to describe his involvement in student activities, Mike responded, "anything anybody organizes, I'm there.” Although Mike had described himself as being comfortable on the campus, he did feel a bit of a social challenge on campus. In regards to participating in activities, Mike explained, "Mostly what I do is try to encourage students to take part in their community. I'm really out of it because of my age and foreign status."

Support. With the exception of Bob and Mike, the participants did not demonstrate being socially integrated into the campus community. However, each of them felt supported in their pursuit of a college education. Upon being asked directly if they received support for attending college, all of the participants confirmed they were supported although the amount and source of support they received varied. The sources of their support included members of the campus community, family, and friends.

The support of members of the campus community was critical for some participants. 
Susan, Mike and Margaret all reported support from members of the campus. Susan, who worked at the college, found support from co-workers. She explained she and one of the staff were very close and "I find myself going to her sometimes." For Mike and Margaret the support of the campus community was much more critical to their success. One of the faculty members was Mike's biggest supporter. The faculty member's support served such a crucial role to Mike that he considered the faculty member his mentor. When asked how the faculty member was supportive, Mike answered:

In every possible way. Forcing me to write, put down things that I would probably rather, in the sense of political correctness, skip; encouraging me to draw from personal experiences, professional ones with class. Giving me the opportunity to... take part in instructing the class... and basically, he's the one encouraging me to go into [the] teaching field.

The support of his instructor was critical to Mike because he received a large amount of criticism from family and friends for returning to school and not finding a job outside his field of interest that would not require a degree.

The support of the campus community was also valuable for Margaret. Although her family was not critical of her pursuit of a college education, they did not provide support. The only source of moral support Margaret referenced came from one of the college staff members. She explained the person was "supportive when I didn't think I could make it."

The major source of support for most of the participants was their families and significant others. Although family and significant others are not a component of integration into the social system of the college, their support was critical to the participants. Their families supported them through providing childcare, giving pep talks, helping with academics, and demonstrating 
interest in their successes in college. Susan, Helen, Betty, Karen, Dave, Nancy, and Lisa all described supportive family members. Although she received some support from co-workers, Susan's biggest source of support was her family. She explained:

I have a wonderful, supportive family. A wonderful, supportive husband, my mom lives next door to me, and my grandmother, so I've always had the support. That's something I do not lack in. And my children also. My children support me. So, I'm very blessed. Susan's husband, mother, and children all supported her by listening to her and boosting her morale. Her family remained supportive of her attempts at college and did not provide negative feedback about what she was doing. Her husband, who was a college graduate, encouraged her to attend college and provided her advice on how to be more successful in college.

Helen also received a great deal of support from her family. As a part of their support, they advised her on what to expect from her academic program and helped increase her morale. She reported she was able to seek academic assistance from her grandmother. Her grandmother had worked in a similar field for many years so was able to explain some program specific terminology and procedures. In addition to the academic support, Helen's grandmother helped with childcare and provided additional moral support by emphasizing her pride in Helen. The only negative comments Helen had received came from co-workers who questioned why she wanted to return to college. She said, "People that I work with are like why do you want to go back to college? Why don't you want to just work here?"

Betty's major source of support was her fiancé. Since he was from the area, he knew more people than she did. When asked how he provided her support, she explained, "he'll just try to throw ideas out on how to approach somebody. He's from here, maybe something they would 
have an interest in that I don't know, not being from the area my whole life." In addition, he motivated her to attend college and achieve her goals. Although other family members did not provide the same level of support as her fiancé did, no one had ever questioned her attending college.

Karen's family was supportive in her attempts at college both times she attended. During her first attempt at college, Karen's biggest supporters were her mother and grandparents. For her second attempt at college, she believed her biggest source of support was her husband. She explained, "The first time it would have to have been my mom and my grandparents I guess. The second time it was my husband, he does a lot of childcare." The only breakdown in support Karen experienced was though family and friends questioning her choice of majors because they did not believe it would be a good fit for her. However, they still did not question her decision to attend college.

Dave described his wife as his biggest supporter. She provided academic help and moral support as well as help in balancing his responsibilities. Dave's described his wife's help when he had problems with his schoolwork. He explained when he considered not continuing in college, "She kind of told me to stick it out." As he attempted to balance his many responsibilities from working full-time, attending college, and raising children, his wife took on extra responsibilities such as additional childcare so he could focus on schoolwork. When asked if his family or friends criticized him for attending college, he said it had not happened. He believed they understood his need to attend college in order to have a good job.

Nancy's biggest source of support was also a family member. When asked about her biggest source of support she said, "My dad, he's a big support person. He helps me out a lot. He gives me help when I need it." Nancy also reported he provided moral support her by telling her 
he was proud of her. Although she described her father as supportive, she suspected he would have preferred she attend a big university. Even with that suspicion, Nancy said none of her family or friends questioned her decision to attend college.

Lisa was one of the participants who named multiple sources of support. One source of support for her was her family. Her family supported her by asking about her classes and encouraging her to continue college when she had personal issues interfering with her college pursuits. After some discussion, Lisa added her ex-husband as a source of support. When she had college related conflicts, her ex-husband took care of their children so she could focus on college. Lisa only referenced one type of negative feedback about her college pursuits. Her mother expressed concern about Lisa attending college when she had many responsibilities in other aspects of her life. Her mother was concerned adding college on top of other responsibilities would overwhelm Lisa and cause her problems.

Some participants were also able to rely on the support of their friends as they attempted college. Susan, Dave, Dorothy, and Lisa all referenced support from their friends. Susan relocated to the area with her family seven years before she participated in the study. She explained friends from where she used to live still provided her some support. Dave had a friend with whom he attended high school that was also attending CCA. Dave met up with this friend to play cards and support one another. Dorothy's friends provided encouragement and support. Dorothy described primarily approaching her friends when she needed morale boosters and emotional support for her college pursuits. In addition, Dorothy worked for a local attorney who encouraged her to attend college for her major, gave her opportunities to learn about and work in the field she was studying, and promised her a job when she finished. However, she did not list him as a support. Lisa's friends supported her in a number of ways. The not only encouraged her 
when she struggled and took care of her son but also were the ones who encouraged her to attend college in the first place. Lisa considered her friends her biggest supporters.

In spite of the amount of support most of the participants reported, some participants received very little support for their endeavors. The only support other than the college staff member Margaret referenced was her brother helping her with a computer problem. Beyond that, while her friends and family were not critical and thought her pursuit of a college degree was a good idea, she did not believe her family understood the demands she experienced with attending college. Bob was one participant who did not reference support from anyone in his life. The closest thing to support he received was criticism for not wanting to attend college. When asked if that was reinforcement from his parents to attend college Bob replied, "No, it was either you go to college or you get out." Although Bob reported no one supported him in his college endeavors, his parents allowed him to live with them, which could be considered supportive. Although Mike received a great deal of support from a faculty member, he did not have the same degree of support outside of the college. Mike was not able to rely on support from his friends and family. They believed he "was taking too much [time] and putting too much effort and they pictured it as overachieving. Even through in my sense it's basic and I don't think it can be done with less, if you really want to do it."

Financial resources. The need students have to obtain financial resources does not end with their admission to college. CCA offers a number of programs to help students meet their expenses related to pursing a college degree. These programs include grants, scholarships, and low-income assistance. Scholarships and grants sponsored through the college total nearly $25 \%$ of the annual expenditures for the college. As an institution, CCA is heavily reliant on state appropriations to balance its budget. Student tuition and fees make up approximately $15 \%$ of the 
college's overall revenue while state appropriations make up approximately $40 \%$ of its revenue. The remaining revenue is derived from grants, contracts, Federal Pell Grants, capital grants, and investment income.

Although CCA provides a great deal of financial assistance for its students, and the college is recognized as having one of the lowest tuition costs in its state, the burden of paying for college may overwhelm students with limited financial resources. The participants in this study relied on a variety of resources to obtain the money they needed to pay for college and for advice on how to obtain that assistance. Financial aid, employment, and low-income assistance were the largest sources of finances so the participants' pursuit of higher education was possible.

Financial aid was a critical component of the participants' ability to attend college. Most of the participants reported receiving some sort of financial aid through scholarships, grants, and loans. Helen described the most reliance on financial aid. In her second attempt at college, Helen obtained grants that covered all class-related expenses including tuition, uniforms, and traveling expenses. In explaining how important the grant was to her pursuit of a college education, Helen said, "I was very fortunate... to get a grant which helps with everything, gas, the uniform you have to get, everything so... if it wasn't for that, I don't know, I would never have even tried going."

Financial aid proved to be critical to the other participants as well. Bob relied on scholarships and loans to help pay for many of his college expenses. When Lisa originally began college, she paid for classes as she took them. However once she divorced, Lisa relied very heavily on Pell Grants to attend college. Mike depended heavily on access to student loans and a small private grant to pay for college expenses. Dorothy paid for her college education through grants from the college and state in addition to scholarships. Margaret received a grant and 
scholarship. Susan was able to obtain some scholarships to help cover the expenses related to attending college.

All of the participants except Dave, Karen, and Susan described using financial aid to pay for college. Dave and Karen both reported they did not have any challenges in paying for college. Dave relied on his ability to access the G.I. Bill and working a full-time job to attend college. Karen explained she relied on the proceeds of selling the family business to cover all of her college related expenses so was not receiving financial aid. Susan explained she did not qualify for student loans or other financially based aid. As a result, she had to take money out of the family's income and work to pay for college. She worked an average of 22 hours a week at the college.

Most of the participants received financial aid through college but none of those who did found financial aid met all of their financial needs. Those participants who received financial aid revealed their financial aid assisted them by covering tuition and fees but did not cover living expenses. To address their remaining financial needs, the participants took other steps. Lisa received a grant that helped her cover expenses but had to find the financial resources to cover the cost of commuting to and from school and eating during the day while she was at school. Lisa monitored her budget carefully and limited her activities out of her house to reduce her costs as much as possible. Margaret received financial aid and financial assistance from a Home Energy Assistance Program for low-income individuals when financial aid did not cover all of her expenses. However, she anticipated having more financial struggles because she had left her job in order to focus on academics.

Many of the participants managed their financial needs by working. This information is concerning when taken into consideration alongside reports that the more hours students work, 
the less likely they are to persist (Bers \& Smith, 1991.) Although Helen received a grant, she found it necessary to work 15 hours a week in addition to attending college to cover her additional expenses. She explained, "That's why I work is to cover my gas and my bills at home. If I didn't have to work to pay those bills, I wouldn't be working." In order to earn money, Mike took odd jobs and tutored. Although Dorothy had access to grants and scholarships, she also worked 10 hours a week for additional money for living expenses. In addition to receiving grants, Betty lived with her fiancé who earned good money in his job and worked 10 to 15 hours a week for spending money. Bob also had difficulty in finding all of the financial resources he needed even with receiving financial aid. He struggled to find the finances he needed to make his daily commute. To supplement his financial aid, Bob worked an average of eight hours per week to pay for books and traveling expenses since he commuted more than 30 miles each way for every day he was on campus. In addition to paying for college, Nancy raised her son on her own and paid for all of her bills. The only financial aid Nancy reported was a small grant. She explained she "took out one loan first semester and regretted that." As a result, she worked 40-50 hours a week to cover all of her expenses.

In spite of their heavy reliance on financial aid, very few of the participants discussed obtaining loans that would place them in long-term debt. The participants preferred to fulfill their financial obligations as they accumulated by reducing expenses and obtaining employment. Nancy explained:

I took out one loan first semester and regretted that. I mean I needed it but I still owe for that. But, one of my friends, she takes out loans like crazy. And I'm like, do you know you have to pay that back? You know, it sounds good right now, but I try to avoid that, if I don't have to.

Financial advice. The participants also had access to few sources of advice on how to 
address their financial concerns. The primary resource the participants used was the Financial Aid Office at the college. Although the participants typically sought assistance from the staff members responsible for financial aid at the college when they had financial concerns related to seeking an education, the participants also utilized other resources. Each participant except Dave described approaching the college's financial aid office for assistance. Dave sought assistance from the college's Veteran's Representative. He explained, “Any questions or anything that I've had, I call her." Bob was the only participant who described getting assistance from a high school counselor.

The Financial Aid Office helped the participants in several ways. Susan, Bob, Helen, Betty, Dorothy, Lisa, Margaret, Mike, and Nancy all reported the financial aid office helped them complete paperwork necessary to obtain financial aid. The office encouraged Betty to apply for additional assistance when she struggled with finances. Margaret reported the Financial Aid Office was helpful to her in a number of ways. Not only did they help her complete the paperwork for financial aid but also helped her find additional financial resources such as utility assistance for low-income individuals. Although Mike said he completed most of the paperwork on-line himself, when he needed additional help he asked the Financial Aid Office. He explained, “There's always something missing when you're a foreigner. There's always something they need for the second or third time.” Hughes (1990) found a significant correlation between students' satisfaction level with the financial aid office and whether or not the staff made the students feel comfortable. Each of these participants described the staff in the Financial Aid office in a positive way and expressed how helpful the staff was.

Families were a resource for a limited number of participants. Helen, Nancy, and Dorothy sought financial help from their families. However, their comfort level at seeking that assistance 
and type of assistance varied from one participant to another. If Helen had any unmet financial need after working through the college, she asked her mother and grandmother for help. She believed she could ask her parents and fiancé for financial assistance but was not comfortable doing so. In addition to asking the Financial Aid Office for help in completing paperwork and advice on how to cover college expenses, Nancy also asked her father. Once she ran out of all other options, Dorothy asked her mother and grandmother for help when she had financial concerns.

Goals and commitments. Tinto (1993) emphasized the importance of students' commitment to their education in their persistence in college. Once they entered college, some of the participants changed their programs of study but they were committed to meeting their new educational goals. Their commitment could be traced through their goals to continue college, their satisfaction and commitment to the college and its programs, and their desires to complete degrees in timely manners.

Post-entry goals. Each of the participants were committed to their educational goals. Of the participants interviewed, Margaret, Helen, and Bob planned to earn certifications while Susan, Mike, Nancy, Dorothy, and Lisa, planned to earn Associate's degrees and Dave and Karen, had specific plans to obtain Bachelor's degrees. Although they did not have specific plans on how to do so, several of the participants, Nancy, Lisa, Dave, Helen, and Karen, considered seeking degrees beyond Bachelor's degrees. Regardless of their desired educational level, each of the participants expressed enthusiasm for continuing their education. Nancy explained she would make the same decisions again because "this is what I always wanted." If Dorothy had to do it again, she would not have taken advantage of the flexible course drop policy and would have taken her classes more seriously. 
Although they were committed to achieving their educational goals at the time of the study, most participants had altered their goals from when they originally began college. Two of the participants chose paths that would require more education while four switched their goals to entirely new programs. With these changes, came increased commitments to their goals.

The type of changes in their goals varied from one participant to the next. Two of the participants, Bob and Margaret, indicated when they entered college they had not decided on a career path but did so after beginning classes. Although Bob said he did not know what he wanted to study when he first began college, he later revealed he did know what he wanted to study but was not able to study the program in which he was interested because of financial limitations. As a result of the difficult decisions he had to make, Bob entered CCA without knowing what program he wanted to study. Within a year, he decided on a major. By the time of the study, Bob planned to earn three certificates: Business Office, Small Business Management, and Legal Office. When she first entered college, Margaret did not know what she wanted to study. Her goal in attending college was to study something that would allow her to find a better job. Margaret said, "I finally made up my mind after the first year" about which program to study. She chose to earn a certificate in accounting.

Two other participants, Dorothy and Dave, decided to pursue more education through seeking higher degrees or by adding certifications to their program. Dorothy originally intended to earn an Associate's degree in business. After beginning classes, she decided to add another Associate's degree and two certifications. By the time of the study, she had added another Associate's degree in the paralegal program and two certificates in the accounting and transcription programs.

At one point in his education, Dave had wanted to get a computer-related degree but for a 
reason he could not remember by the time of the study, he dropped the program. At the time of the study, Dave planned to continue his education beyond an Associate's degree, but had not decided on a specific field. He explained when he first decided to attend college "was just to graduate, to just get whatever I needed to get a degree." By the time of the study, he had decided he wanted to earn at least a Bachelor's degree if not a Master's degree.

Two other participants, Karen and Lisa, switched to entirely different programs than they had originally studied. When Karen first entered college, she considered a Bachelor's degree in education. Since that time, she had switched her degree program to nursing. She planned to earn an Associate's degree at CCA and then transfer to another nearby college that offered a Bachelor's degree in nursing. Lisa switched from Nursing to Psychology and planned to earn an Associate's degree in human services. Eventually, she wanted to earn a Master's degree or more but planned to begin with an Associate's degree. She explained she made the change because she believed the change was a better fit for her interests.

Two of the nine participants, Helen and Betty, changed their career paths from one health services program to another. Helen explained she originally planned on a degree in radiology but had changed to respiratory because after researching the program, she believed it was a better fit for her interests. She explained, "I believe you help more people in the respiratory, you know cause I mean radiology because you do their x-rays, granted you do help them, but respiratory, if you can't breathe, you can't do anything." Helen also considered pursuing a lower degree level than she originally planned. She planned to make a choice after she finished her Associate's degree.

When Betty first began college she was interested in a radiology program but was led to believe it would be "almost impossible" so she decided to take classes to improve her 
educational level in general. By the time of the study, she switched back to the program in which she was originally interested. She explained, "I'm looking at radiology school again. They just made it seem so hard, and then I did well in the classes that I think you would need, and then so maybe it won't be so hard."

Three of the participants, Mike, Susan, and Nancy, maintained the same or similar goals as when they entered college. Prior to moving to the United States, Mike had attended a military command college and earned certification as a "criminalist" which he described as the technical side of police investigation. Because his prior training and experience was not recognized in the United States, he decided to attend an American college and receive the credentials he needed to work in the same field in the United States. When asked why he had the same goals, Mike explained his goals had not changed because "I'm very persistent." While he said he had the same goals, he discussed expanding the content areas he was studying. At the time of the study, he was pursing Criminal Justice, History, Social Science, and International Relations.

Susan and Nancy had similar career goals. When Susan entered college, she planned to earn an Associate's degree in nursing. At the time of the study, she was considering a Bachelor's degree or beyond. Nancy's career goals were similar but more finely tuned. She still wanted a career in art, but decided to focus on advertising and a career where she would not have to interact with large groups of people. She believed this change was a better fit for her interests. She also was not as convinced of her degree level goals. She originally planned to earn an Associate's degree then a Bachelor's degree. She said with the addition of being a mother, "I don't know if that's going to work out. So, I'm playing it by ear now."

The participants' career goals ranged from specific uses for their educations to completely undecided about how to use their educations. Bob, Margaret, Susan, Dorothy, Karen, 
and Helen were specific about their career goals while Mike, Nancy, Lisa, Betty, and Dave were not. The two participants who planned to finish their education upon obtaining certifications were specific about educational goals but very vague about career goals. One of these participants, Bob, planned to earn multiple certifications but no degree. He planned to use his certifications to find a job in the area but was unsure in what field that job would be. Another participant, Margaret, was specific about the field in which she planned to earn a certificate but was not specific about her career goals. She explained she planned to work in a business in the local area.

Other participants, Susan, Dorothy, Karen, and Helen, were much more specific about their career goals. Susan expected to begin her nursing career working in a hospital setting then move to nursing in a business setting such as a doctor's office, school district, or company. Dorothy decided to obtain an additional degree and certifications in order to make herself more marketable as an employee. She was specific about her desired career path. She planned to work with data entry. She preferred to have a job in a hospital or law firm. After earning her Bachelor's degree, Karen planned to decide on future career paths. She was interested in eventually being either a Nurse educator or a Nurse Practitioner, which would require additional education beyond the Bachelor's degree. Helen intended to earn at least an Associate's degree in respiratory therapy. She plans to obtain licensure to practice in a neo-natal intensive care unit. Mike, Nancy, Lisa, Betty, and Dave did not have specific career goals. Although Mike said he had not changed his goals, when asked what he wanted do with his degree once he finished it, he provided a much different response than conducting police investigations. He explained, "I would probably work for the [U.S.] State Department... but I would prefer teaching. Hopefully, change the world politics... Or at least the understanding of it." 
By the time she participated in the study, Nancy still wanted to work in an art-related field but did not want to work with groups of people any longer. She hoped to earn an Associate's degree and work in advertising. However, the college did not offer an advertising program so she did not know what she wanted to go into. Her long-term career goals were undecided. She was even considering beginning a career in another field.

Lisa planned to earn her Associate's degree but was unsure of how she would use it. She explained she eventually wanted to be a counselor of some sort. She hoped to one day earn a Master's degree or more so she could work as a counselor. The areas of counseling in which she was interested were working with children, marriage counseling, or drug and alcohol counseling.

Betty planned to obtain a degree in a health care field but was unsure of how she would use that degree. Eventually, she hoped to be an ultrasound technician in a hospital or doctor's office. She explained, "I don't think that I'd want to be in an emergency room, like X-ray tech. I don't deal well with trauma, my own or anybody else's."

Dave knew he wanted to expand his education but was not sure how he wanted to use that education. He was considering getting a Bachelor's degree and possibly a Master's degree but did not know in what field he would do so. His intent for earning the degrees was "Just use it to maybe fall back on if something happens, if that plant shuts down or something."

Post-entry commitment. Students who are committed to an institution or program are more likely to persist (Bers \& Smith, 1991; Tinto 1993). All of the participants indicated if they were to go back to the beginning of their college careers, they would have still enrolled at the institution. The participants consistently referred to the college as supportive, comfortable, helpful, and convenient.

The convenience of the college being local was one reason students would re-enroll at 
CCA. Margaret, Bob, Betty, and Nancy all cited the college's location as an asset for them. Margaret liked the college's convenient location and found the members of the campus community to be friendly. Bob also cited a main reason for his satisfaction with CCA was its location and low cost. He explained, "It doesn't require my parents to take out loans, or me, and getting in debt for it." Dave would choose CCA because of its convenience. He explained, "It wouldn't matter really where I went to college as long as I get a good degree." Although its convenient location was a major reason Betty would re-enroll at CCA, she also was pleased with the college itself. She explained, "It's a good school, I think," She added, "My parents tried to push community college, but I didn't go. Now I understand it's not a bad thing." Another participant, Nancy, joked about the college's rural location but continued to explain why she liked the college:

This place is like a black hole, it keeps sucking you back in. I've moved away from here I don't know how many times and end back here. It's a good area. Like I told you before, I just like the smaller schools. I like the close atmosphere to a point. I like it better. I wouldn't trade this school.

The members of the campus community were another asset some students cited for why they would want to re-enroll at CCA. Susan explained she would enroll in CCA because the quality of experience she had there. She explained, "They've done nothing but been good to me here... academically, and... as far as employment also.” One of Lisa's main reasons for being satisfied at CCA was the friendliness of the members of the campus community. She explained, “It's a nice college, it's small, people are very personable here, the staff has been great, and the girls in the office are very helpful, I've made a lot of friends and I basically am comfortable here.” Karen explained, “It's just a great environment to learn in. Everybody's concerned and 
willing to help. The teachers want you to do well. They want you to learn. I can't imagine a better environment." Helen said:

I think it's a very good college. Very small. Everybody's real helpful and nice. They make you feel real comfortable, and it's a lot of one-on-one. Some colleges are so big you don't get that one-on-one help that you need.

Dorothy specifically liked the atmosphere of the college. She found the college to be flexible about working around the schedules of students who were also parents. She explained, “They'll make any situation convenient for anybody." When describing her experience at CCA, she said she would "be a lifetime student here I love it here so much." The only reason she named for her going to another college was the limited degrees that were offered at CCA. If she wanted a degree in another area, she acknowledged she would need to go to another college.

The choice of majors was one negative aspect about the college for some of the participants. Dorothy and Mike both discussed the limited program of study options available at the college. Mike said he would re-enroll at CCA for financial reasons. However, if he did not have to worry about the financial aspects of attending college, he would have enrolled elsewhere. He explained, "I would probably choose a college or university that I could continue from the beginning to the end in the field I'm interested in, without the need to transfer."

Students' satisfaction with their program of study is another component of their commitment to completing their degrees. All of the participants except one indicated they would choose the same program as the one in which they were enrolled at the time of the study. Each of the participants who would have chosen the same major said they enjoyed the program and looked forward to working in the field.

Karen who had already completed a degree in business and returned to complete a degree 
in nursing was very committed to her new program of study. She believed nursing was a better fit for her interests. She explained, "It's challenging... it seems like more of a... way to give back... To be helpful." When asked why he would choose the same program, Mike explained, “That's the field where I've spent all my life and basically, I don't think I could be good at anything else." When asked the same question, Dorothy explained, "I love a business environment. I actually thought about nursing... but it's not something that I could find myself excited to go to work every day."

Dave was the one participant who would have made a different program choice. When Dave first enrolled in college, he planned to study computer science. For a reason that he could not remember, he decided to switch out of the program. If he had it to do over, Dave said he "would have stayed with that instead of an Associate's in science."

Based upon their student statuses, the participants were committed to completing their programs in a timely manner. Cofer and Somers (2000) reported students enrolled as full-time were more likely to persist. Eight of the participants were enrolled as full-time students. For five of the participants, Helen, Betty, Mike, Bob, and Margaret, this was a typical pattern for them. Betty explained she enrolled on a full-time basis because, "I do have the Pell Grant so as long as I keep it full-time, it's stable right now." The other three participants enrolled full-time, Susan, Nancy, and Lisa, did not always enroll on a full-time basis. Susan was enrolled as a full-time student at the time of the study but did not usually do so. She explained, "This is my first time ever I've picked up this large amount of load and I'm realizing it's too much.” As a result, she did not plan to enroll on a full-time basis in the future. At the time of the study, Lisa was enrolled on a full-time basis. However that had not always been the case. Beginning with the semester she participated in the study, she intended to remain at full-time enrollment because she felt more 
pressure to complete her degree and obtain a paid job since she and her husband divorced and she was bought out of her half of the business they owned. Nancy had not previously registered as a full-time student. Often she would only be one or two hours short of full-time status. She discovered that she would receive more aid if she were full-time so added the extra hour to ensure she could get additional money. With this realization, she decided to continue enrolling on a full-time basis.

The other participants, Karen, Dave, and Dorothy were registered as part-time students. It was typical for Karen and Dave to enroll on a part-time basis. Dave explained, "I took full-time my first semester here and it was too tough." He found it difficult to balance the demands of his classes with his job and family responsibilities. Dorothy typically enrolled on a full-time basis but had not done so the semester she participated in the study. She explained, "This semester they didn't offer very many classes for my degree because I've taken them out of order. So I just have to kinda pick up what I didn't have already."

Horn and Berger (2004) reported students were more likely to remain in college as they progressed through their programs. The participants of the study were halfway through their programs and had specific plans to finish their programs. Susan expected to finish the nursing program within three years. Karen anticipated finishing her degree within two years and transferring to another school. Dorothy expected to finish her programs within a year and a half. At that time she would have two degrees and two certificates. Helen, Betty, and Mike expected to complete their degrees within one year. Lisa thought it might be a possibility to finish the following semester but was not positive she could do so. Bob expected to finish one certificate the semester of the study, two the following semester, and the fourth certificate the next semester. Margaret was the participant with the shortest amount of time left to her completion. 
She was in her final semester of her program. Dave could have finished his Associate's degree the semester he participated in the program but planned to continue taking classes for the remaining two years his G.I. Bill would last.

Terenzini et al. (1996) found although FGCS are not academically prepared for college and gain more than their non-FGCS counter-parts by studying, they are less likely to do so. Many of the participants of this study supported those findings. Many of the participants who were enrolled on a full-time basis spent very little time preparing for their classes. Susan only spent an average of two to three hours per week studying. Margaret reported studying approximately five hours a week. When directly asked how many hours a week she studied, Nancy responded, "I'm glad this is just between us, I would say maybe 5 hours a week." Although he was a full-time student, Bob studied less than 12 hours a week. This was less than three hours per week for each of his classes.

Other participants demonstrated much more commitment to preparing for their classes. Of the participants enrolled on a full-time basis, Helen explained she studied every day and all day on Sundays so spent approximately 18 hours a week preparing for class. The amount of time Betty spent studying depended on her course load. As a full-time student, she reported spending 13-25 hours a week studying. Lisa reported spending approximately 16 hours per week studying. When asked how many hours a week he studied, Mike explained, "probably two or three times more than I spend in class... then if I'm doing some research, then... it's immeasurable."

The participants who were registered as part-time students demonstrated more dedication to preparing for their classes than some of their full-time counterparts. Karen explained she spent average of eight hours per week. Dorothy described studying "four hours for each class, I'd say at least 8 hours a week. I only have two classes right now." Dave reported spending one of the 
highest number of hours preparing for his classes. On average, he studied 20-25 hours a week. 


\section{Chapter 6: Southern Community College}

This chapter reviews the experiences of participants from Southern Community College (SCC). It begins with a description of the institution and general descriptions of each of the participants. A discussion of participants' precollege academic preparation, social support, and financial resources follows. Afterwards, there is a discussion of the participants' experiences integrating into the academic and social systems of the college and obtaining the financial resources they needed to continue their educations. The chapter ends with a summary of the experiences of the participants and how those experiences influence the participants' decisions to continue their educations.

\section{Institutional Background}

Southern Community College is a small, two-year, state funded college in the southcentral part of the United States. The college has an enrollment of approximately 1,500 students (Carnegie Foundation for Teaching, 2011). The college was founded as a Vocational-Technical

School in the mid-twentieth century. Toward the end of the century, the institution merged with a regional state university. Since then, the citizens of the area approved a sales tax providing for the expansion of the college (SCC Catalog, 2011).

The facilities for the institution include six buildings. Classes on the campus are housed in multiple buildings. In addition to instructional settings, these buildings house the campus bookstore, student service offices such as financial aid, tutoring, and advising in addition to a library. The campus is located in a rural area outside of a nearby town of approximately 10,000 .

The mission of the college is to "connect students and community partners to quality education and to support a culture of academic occupational personal growth and enrichment programs" throughout the area (SCC Catalog, 2011). The college aims to "foster and support the 
educational, cultural, and economic development" of the area. The college's goals are:

1. To provide quality university parallel courses on the freshman and sophomore level:

a. for students who wish to obtain Associate degrees, and

b. who will transfer to another institution;

2. To provide quality occupational courses for:

a. Students who wish to obtain Associate of Applied Science degrees;

b. Students who wish to obtain Technical Certificates;

c. Students who wish to gain competence in employable skills; and

d. Employed workers who wish to upgrade their skills.

3. To provide a general education base for liberal arts and technical education.

4. To provide credit and non-credit continuing education courses.

5. To provide community service activities by:

a. Sponsoring courses to meet the interests of various groups;

b. Offering facilities and professional staff to promote the civic and cultural life of the service area;

c. Fostering intellectual and social interaction through participation in community life, and

d. Providing a culture and environment that encourages lifelong learning for all members of the community.

6. To provide organized academic skills courses designed to improve skills so that success in a program may become possible.

7. To provide students with counseling, financial, and other support services important to their personal growth by recognizing that each student has his or her own needs, interests, 
and abilities (SCC, 2011).

In order to assist students in their success, the college requires all students to submit ACT or SAT scores or to take placement tests prior to registering for class. Students who do not meet the minimum test requirements in math and English are required to enroll in and complete academic skills courses until they meet the requirements and to enroll in a college success seminar.

\section{Study Participants}

I contacted SCC requesting permission to conduct this study in addition to requesting assistance in identifying students classified as first-generation college students who had completed half of their program requirements. An administrator agreed and offered to assist me in contacting participants. Once the administrator and I agreed upon a schedule for the site visit, he identified students who had earned 20 to 70 hours and contacted the students via e-mail explaining my study, the general guidelines for inclusion in the study, and when I would be meeting with students and conducting interviews. He arranged for me to have an informational table available in the student center area and a room in which to hold an informational meeting about the study on the first day of my visit to campus. While at the table and in the meeting, I was able to make personal contact with students and explain the study. Throughout the day 14 students agreed to participate in the study over a three-day period. However, the college closed the third day due to a weather related emergency. As a result of the closure, I was only able to interview seven of the participants.

The participants of the study represent a variety of backgrounds and experiences. I interviewed a total of seven students, four female and three male. The participants of the study ranged in age from 19 to over 60 years of age and are all within the first generation of their 
families to attend college. Sandra is a Native-American, White, and Hispanic mother of three who was 21 at the time of the study. Her mother completed the eighth grade and her father left school before finishing the sixth grade. Sandra is one of three biological siblings and seven adoptive siblings and the only one to attend college. Bill is a single father of mixed race origin, White, African-American, and Native-American, who was 40 at the time of the study. He believed his mother finished either the ninth or tenth grade and his father finished either the seventh or eighth grade. Bill's father later earned a GED after he left the military. Bill is one of 11 children and the only one to attend college. Lenny is African-American and was 19 at the time of the study. He believed his mother may have taken some college classes but knew she had not earned a degree. Lenny also believed his father attended college but was not sure how long. He is one of 12 children and the only one to pursue a college education. Donna is White and was over 60 at the time of the study. Her mother and father stopped attending school while they were in high school, and Donna did not believe either graduated high school. She is the eldest of 11 children and the only one to attend college. Chuck is White and was 19 at the time of the study. His mother graduated high school and began college but did not complete a degree or certificate. His father finished the third grade. He has one older sister who began college but dropped out three weeks into the first semester. Carol, who was 24 when she participated in the study, is a White single mother. Her mother dropped out of school after the ninth grade and her father graduated high school. She is one of five children. Her younger brother was enrolled in college but she would be the first to earn a degree. Ruth was a married, White mother who was 54 at the time of the study. Her mother and father both graduated high school. She is one of three children and the only one to attend college. 


\section{Pre-College Characteristics}

FGCS encounter a number of roadblocks when they pursue a college degree. These roadblocks center round their academic preparation, support, and financial resources leading up to their entering college.

Academic preparation. The participants demonstrate a wide range of academic preparation for college. Some followed a more traditional path and entered college directly after high school while others entered college after being out of school for several years. Lenny, Carol, and Ruth all began college directly after high school. Lenny entered college soon after graduating high school and attended continuously. Carol entered college directly after high school but after a car accident, took over two years off to recuperate before re-entering college. Ruth enrolled in college immediately after high school but only completed one year before leaving. She returned to college 30 years later. The other four participants, Donna, Bill, Chuck, and Sandra pursued college in less traditional manners. Donna seriously pursed college 30 years after graduating from high school as a part of her desire for a career change although she had taken college classes occasionally over the years. Bill graduated high school and entered the military. During his time in the military, he served in various combat areas. After approximately 20 years, he left the military as a disabled veteran and enrolled in college. Chuck and Sandra dropped out of school and later earned GEDs. In spite of the different paths they took to college, like participants in other studies (Chen \& Carroll, 2005; Horn \& Nunez, 2000; Humphrey, 2000; Terenzini et al., 1996), the participants of this study for the most part were not prepared for college.

Even those participants who entered college directly after high school attended college in different manners. Lenny graduated from high school and entered college shortly thereafter. He 
took classes continuously. Although he entered college soon after graduating high school, Lenny does not believe he was prepared for college. He described struggling in classes which required more than minimal reading and writing. While he did not discuss having difficulty in math, he did report needing to take remedial math classes. Both of these experiences demonstrate a lack of preparation for the academic demands of college.

Carol and Ruth began college directly after high school but they both pursued college in a start and stop manner. Carol originally entered college directly after high school. However, she was in a car accident after her first semester. As a result of the accident, she was not able to perform the physical labor demanded in her diesel mechanics program. She reentered college when she decided she had recuperated enough to be able to do the work. However, she regrets the time she took off from college and believes she had more difficulties the second time she attempted college. She explained:

I would've finished. I kicked my butt for that every day because it's a lot easier finishing before kids. One thing that I've learned is that things that I thought was hard in the past, is nothing. I mean there was no reason, no good reason.

When asked if she believed she was prepared for college, Carol said she believed college classes were easier than high school classes. However, she described having difficulties meeting the college's math requirement. She explained, "It doesn't come easy for me I have to struggle." In addition, she described seeking help from a math tutor. In contrast to her self-assessment, her descriptions of her experiences demonstrate a lack of preparation for college level academic work.

Ruth also began attending college directly after graduating high school. However, she dropped out of college after her first year. She chose to leave college in order to work and to pay 
for her husband to finish his education first. She later returned to college and earned an Associate's degree from SCC 30 years after dropping out of college. While working for the college, she also had the opportunity to complete her Bachelor's degree and was pursuing a Master's degree at the time of the study. She believes she was prepared for college when she first enrolled. Based on her reports of not taking remedial courses and performing well in her classes, it appears that she was prepared for college level academic work.

Other participants followed even less traditional routes to higher education. Donna graduated high school and took a few college classes for several years before participating in the study. Thirty years after finishing high school, Donna was unemployed and decided to pursue a degree on a full-time basis. She does not believe she was prepared for the academic demands of college. Prior to college, she had never taken an Algebra class. In addition, because she had been out of school for such an extended time, technology had changed. In her previous educational experiences, she did not have access to computers so was unprepared for her encounters with the technology being used in her classes. In addition, she was not prepared for the environment she would encounter. Her faculty told her all assignments and notes were on the syllabus and on the class webpage. In order to access the webpage, she had to find out how to get student identification, how to use a computer, and how to access the webpage in addition to learning the material itself. She described her first week as "pretty much, a slap in the face." Because of her feelings of being overwhelmed, she limited the number of classes she took each semester. She later regretted that decision. In retrospect she said, "I've wasted some time. I go back and I think I could've had extra classes under my belt as opposed to now." Based on these experiences, Donna was not prepared for college.

Bill graduated high school and entered the military. After leaving the military, he decided 
to attend college. At the time of the study, he recognized he was not prepared for college. Although he had strong English skills, Bill explained he had always struggled with math in school and after beginning college his experience with math was no different. Because he struggled with math, he chose to enroll in remedial math classes and had difficulties learning the material in those classes. Bill's struggles did not end with academic challenges. When he entered college, he was a single-parent who had left the military shortly before entering college. He anticipated encountering many differences between other students and himself but did not anticipate the extent of the differences. He explained:

I figured, I'm going to be competing with kids half my age, that know nothing about life at all and I was right about that. The kids that go here, most of them have never been in the military and they don't know what struggling through one day to the next is. And whereas me, I've been out in the world. I've been all over the world Egypt, Africa, Israel; I fought two wars; to come home and you know, have to deal with this. It can be a headache sometimes.

In addition to struggling to adjust the college environment, he had to balance his responsibilities as a parent with those of being a student. He explained, "I was not prepared for the jolt, at all. It was a shocker." His lack of preparation was evident in his living arrangements at the beginning of his college endeavors. When he first began college, he was homeless and lived out of his truck. He did not find a place to live until his second semester in college. In spite of not being prepared for the environment, Bill believed he had an advantage over many other students. He explained:

I've struggled a lot through life. I mean, I've had things to happen to me that hasn't happened to others that are first years. Being in the military has helped me a lot, being 
raised by two parents that were in the military, fighting in a war and everything, going overseas, meeting different people, learning different cultures, has given me an edge you might say, and I'm more disciplined than a lot of these kids and stuff here. I'm more worldly, more cultured, that's given me a big advantage over a lot of them.

Chuck, who was also a veteran, dropped out of school in the ninth grade and later earned a GED while he was incarcerated as a juvenile. He recognized he was not prepared for the academic demands of college. Not only did he struggle in classes, he also struggled with balancing family responsibilities with those of being a student. In general, he did not believe he was prepared to be able to expand on basic information for his classes. He believed when he was in the military, he was taught to stop thinking and focus on doing what he had been trained to do. Once he entered college, he had to learn how to expand on the basic information his faculty provided.

Sandra and her family lived a transient lifestyle when she was growing up. She dropped out of public school and earned a GED during what would have been her seventh grade year. She originally entered college at the age of 16 but left three weeks into her first semester. Five years later, she re-enrolled in college. When she did re-enroll in classes, she was not required to take any remedial classes. However, she described having difficulty with how faculty instructed her classes. When faculty provided multiple methods of doing an activity, she became confused and was not able to perform the task. Sandra demonstrated being academically prepared for college but not prepared for the environment she encountered.

Of the seven participants, Ruth was the participant who demonstrated being the most academically prepared for college. She entered college and performed well in her classes. Her departure from college was a personal choice related to her marriage during her first year of 
college and was not a result of academic difficulties but financial ones. The other six participants each demonstrated a lack of preparation for one or several aspects of college. They had difficulties in their classes and several enrolled in remedial classes. In addition, several of the participants were not prepared for the environment they would encounter when they entered college.

Financial resources. Students' integration with colleges' academic and social systems are also influenced by their financial resources. Without the financial resources they need to participate in the systems, students are not able to academically and socially integrate into the systems. This is a concern because research has shown FGCS tend to have limited financial resources (Horn and Nunez, 2000).

The participants of this study support those findings. Their lack of financial resources served as a major roadblock for many of the participants in pursuing college educations. Without financial assistance programs, the participants would not have been able to attend college because they lacked personal financial resources. Donna relied on unemployment benefits and financial aid to cover college related expenses. If it had not been for the G.I. Bill, Chuck, Lenny, and Bill would not have been able to attend college because of their limited financial resources. In describing his financial situation, Chuck said "I was broke when I came to school. I didn't have money for books." Bill's finances were so limited he lived out of his truck for a semester because he could not find affordable housing. When Sandra first attempted college at the age of 16, her parents could not pay for her expenses and she did not have any money of her own. As a result, she dropped her classes and waited for five years to attempt college again. Carol's finances were so limited she struggled to provide food and other essentials for her daughter while attending college. When Ruth first attempted college, she would not have been able to do so 
without scholarships because her family's financial resources were so limited. Even with scholarships, she made the choice to drop out of school in order to work while her husband attended college because they would not have had money for rent otherwise. When she reentered college many years later, she was able to do so because she received a tuition waiver as a part of her job at the college.

Social support. The support students receive plays a critical role in their goals of seeking college educations (Tinto, 1993). Non-FGCS are encouraged from a young age to attend college upon graduating high school. However, Horn and Nunez (2000) reported this is not often the case for FGCS. Some of the experiences of the participants of this study are consistent with these findings while others dispute those findings.

Four of the participants had been encouraged to attend college before they were adults but only one of those participants were encouraged to attend college before they were in high school. Carol was the only participant who was encouraged from a young age to attend college. She was first encouraged to attend college by her father. He encouraged her to be independent and pursue a job beyond working at a fast food restaurant. She explained, "I think his exact words were don't ever depend on a man, you have to always be able to fend for yourself." and "You don't want to work at McDonald's for the rest of your life so go to college and get a degree." Her experience of being encouraged from a young age was inconsistent with the findings of Horn and Nunez (2000).

However, the rest of the participants were adults or nearly adults before they received that encouragement. Their experiences support reports by Horn and Nunez (2000) that FGCS often are not encouraged to attend college from a young age. One of Donna's co-workers when she was an adult was the first person to encourage her to attend college. Her co-worker changed 
careers when she was close to the same age as Donna and that knowledge motivated Donna to enroll in college. Donna explained, "I think she set an example to me that I wasn't too old." When Donna was laid off from her job, she decided to enter college. She believed she was at an age that if she wanted to make a career change, she needed to do so before it got too late for her to do so.

Lenny was first encouraged to attend college by his grandmother during his senior year of high school. Although she had mentioned going to college to him prior to his senior year, she had not emphasized it until then. His grandmother emphasized to Lenny that she wanted at least one of the children she helped raise to get a college degree and be the first one in the family to go to college.

Bill was encouraged by several people to attend college. His first source of encouragement to attend college came from his mother. When he was in high school, she discussed his strengths in reading, writing, and history. In addition, she constantly encouraged him to increase his knowledge of history. He continued to be encouraged by his first commanding officer and friends when he was an adult. This encouragement let to his enrollment when he left the military.

Ruth had very little encouragement to attend college. She explained she was always academically oriented but received very little encouragement to attend college. Her one source of encouragement came from a high school English teacher. That teacher pushed Ruth to succeed and recognized Ruth's desire to learn. Ruth explained, "She recognized that, just a simple gift of a little book meant a lot, an anthology, I think I still own that book, because it was an encouragement to me to follow through."

Sandra's grandmother provided her first encouragement to attend college after Sandra 
was an adult. Her grandmother emphasized her desire to have one of her children attend college but none of them were able to do so because of a lack of financial resources. Sandra explained her grandmother was in the hospital and was not being properly cared for by the nurses. Her grandmother instructed her to make sure she was studying something she loved, not just what she believed she would be paid well to do. This led to Sandra's career selection.

Chuck was first encouraged to attend college by a friend when he was an adult. Chuck had enrolled in college once but moved away from the area before he started classes. When he returned to the area, Chuck's friend encouraged him to attend college and offered to help him with the process. Although his family was supportive of his endeavors, they had not encouraged him to attend college.

Goals and intentions. Research indicates FGCS have many different reasons for entering college (Van T. Bui, 2002). The participants of this study were no different. They provided two main reasons for attending college. These reasons included a general desire to improve job opportunities and to achieve personal goals. Personal goals played a role in all seven of the participants' decisions to attend college. For most of the participants, their reasons for attending college were a blend of the two.

Chuck decided to enter college in order to meet his personal goals of improving himself and having more opportunities. Because he had dropped out of school and later earned a GED, he wanted to prove to himself that he could do better academically. In addition, he believed if he was more educated, there would be more opportunities available to him. The reason he chose an EMT/Paramedic program was to balance the skills he had already learned in the military. He explained, he "had learned how to kill people and wanted to learn how to heal them as an EMT or paramedic." 
Sandra decided to enter college in order to improve her opportunities. Through increased job opportunities, she believed she would be more financially secure than her parents had been. She explained, "I didn't want to be broke like my parents." The career she believed would lead her to financial security was wedding planning. When she entered college she planned to be a wedding planner and photographer and then earn a Bachelor's degree in business However, the college does not offer a degree oriented toward wedding planning. As a result, she elected to earn a degree in nursing and medical office management which would provide her financial security.

Ruth enrolled in college to meet a personal self-improvement goal and to have more job opportunities. For her, self-improvement translated to a college degree. As a result, she made the decision to attend college while she was in high school. In addition to meeting her goal of improving herself, Ruth also wanted to have more job opportunities that would allow her to financially support herself. Ruth described herself as academically oriented and frustrated at her lack of access to additional information. She explained, "It was a decision I made in high school. I was always frustrated because having read pretty much every book in the library, I felt like there was more to be found, to be discovered." Ruth believed by attending college, she would be exposed to information that would help her learn and grow as an individual. In addition, she would be able to find a career that would allow her to financially support herself. At the time of the study, Ruth was studying a program that was related to her job at the college.

Bill began college in order to meet his personal goals of an increased educational level and active involvement in something. He explained, "I don't like to be bored I like to be active, always doing something. So, college gives me that opportunity." In addition, he was interested in becoming a History teacher because of his long-term interest in history. He had been dissatisfied with history teachers he had previously encountered and wanted to be a better teacher than he 
believed his had been.

Lenny's major reason for entering college was to meet his personal goal of finding a productive way to use his time. He explained, "To get off the couch, actually find something to do, and to keep me out of trouble." As he enrolled in college, he wanted to expand his opportunities. In addition to completing a certification program in Welding, he also planned to take general education requirements so if he decided to pursue a degree later by transferring to another college; he would be able to do so.

Donna enrolled in college to meet her personal goals as well as to have more job opportunities. She had always thought about going to college and had taken an occasional class over several years. One of her co-workers had attended college and made a career change and Donna discussed the co-worker's experiences with her. After being laid off from her job, Donna made the decision to enroll in college on a full-time basis. She decided she also was interested in making a career change and decided to attend full-time and focus on getting a degree in nursing. She believed this career change would allow her to pursue an area of interest to her.

Carol's major goals in pursuing a college education were to meet personal goals and to improve her job opportunities. By earning a college degree, Carol believed she would be able to provide a better life for herself and her daughter. Although it had been a personal goal to attend college and obtain a good job, having her daughter made Carol more dedicated to attending college. She explained, "I'd always planned on it but I have a two year old now that depends on me and only me so there's not a whole lot of a question there. I had to.” Because she enjoyed tearing apart and reassembling mechanical products, she decided to enter the diesel mechanics program at the college. 


\section{Post-College Entry}

Once they enter college, FGCS have a number of challenges they must overcome before they are able to successfully graduate. Successful integration into the academic and social systems of the college plays a critical role to the success of students' pursuits of higher education (Tinto, 1975). When students are successfully integrated into college, their commitments to college and intentions to complete their educations influence their decisions to continue through to graduation or to depart the college. The participants of the study discussed their experiences with the academic and social systems of the college as well as their financial resources, goals, and commitments. These aspects all influence students' abilities to be academically and socially integrated into a college.

Academic involvement and integration. After students enter college, the extent they are integrated into the academic system of the college contributes to their successful completion of a degree or program (Tinto, 1975). Students who are academically integrated find a match between their skills, interests, and needs with the academic characteristics demanded by the college. The perceptions students have of a match can be enhanced through positive academic performance and interactions with faculty and staff.

Academic challenges. Students' experiences in the college classroom and resulting positive academic performance are influenced by their academic preparation (Nora, Attinasi, \& Matonak, 1990). In spite of the general expectation that students will enter college with basic academic knowledge and skills, many FGCS do not (Fallon, 1997). When students do not have strong academic preparation, they often experience difficulties in their classes and may not find a fit between their own skills and interests with those expected by the college. This proved to be a challenging area for the participants of this study. Only one of the participants of this study did 
not report some level of difficulty with the academic aspects of seeking a college education. Almost all of the participants described some sort of challenge with college-level coursework which demonstrated their poor preparation.

The participants most often described their general academic skills and abilities as lacking when they discussed the academic challenges they had experienced. However, many also reported difficulties with the academic content of their classes. The participants' experiences support findings (Van T. Bui, 2002) that FGCS are less prepared for college. As Lenny explained, “I wasn't one of those people that wanted to jump straight into academics. I didn't really think that I would be able to do all the academic work." However, the participants often attributed their academic challenges to their own deficiencies, not to poor academic preparation. In addition to attributing their academic difficulties to their own deficiencies, Fallon (1997) reported they often blame their difficulties on juggling the demands of their lives.

As Donna described her experiences, it became clear she was prepared neither for the academic demands of college nor for the college environment. She described her first experiences in college as a "slap in the face." One of the areas she reported having struggles was in fulfilling the college's math requirements. In accordance with reports from Horn and Nunez (2000), Donna did not take higher-level math classes when she was in high school that would have prepared her for college. However, instead of citing her lack of preparation as the reason she struggled, she attributed her challenges to her lack of math skills. Donna explained, "What's difficult about it is that I don't understand it. I have never had algebra before so I had to start from level one." In addition to her poor preparation for the academic demands of college, she also was not ready to address the environment of a college campus. Again, she did not attribute her difficulties to poor preparation but instead to skills. She explained, she did not know how to 
use a computer and could not access class notes and class web-pages. She explained:

I didn't know what I was getting into and when I walked into the college here.

Everything is computers. I found my first week trying to figure out what I needed to do. I

had to learn how to get on the computer. I had to learn how to pull up my notes.

Chuck was unprepared for the academic demands of college as well as for the college environment. He reported struggling to meet the college's English requirements. However, like other participants, he did not attribute his struggles to poor preparation but instead to his background. He attributed his struggles in writing and speech classes to his family not using proper grammar. He believed because his family did not use proper grammar, he had difficulty knowing how to communicate in his writing and speech classes. In addition to these academic challenges, he also was not prepared for the college environment. His previous experiences did not teach him to think independently, expand on basic knowledge, and understand how to balance the many demands of his life. He found he needed to think much more independently in college than he was accustomed to doing from his time in the military as well as from his previous educational experiences. He described his military experience as training him not to think but instead to rely on his training. In his previous educational experiences, teachers provided much more detail than college instructors did. College instructors provided basic information about the subject matter and expected students to expand on that information to develop a final answer. Chuck described experiencing difficulties balancing his family responsibilities in addition to his schoolwork.

Even though Sandra believed she was prepared for college, she struggled to balance her family responsibilities with those of being a student. She described having difficulty attending her classes because the college did not provide childcare services. She also reported struggling to 
take care of her children while also attending college. In contrast to the findings of Van T. Bui (2002), Sandra did not recognize she was not prepared to meet the academic demands of college. She reported she was academically prepared for college and attributed her academic difficulties to faculty not caring about students and providing too many ways of completing the problems. She explained:

In one of my classes the teacher likes to teach seven or eight different ways of how to do one thing and I've told her that confuses me. You can't mix all that stuff up together for me because then I don't understand it and I can't get it."

Her instructor responded she was showing other students an easier way of doing things and if Sandra could not grasp the material then maybe she should drop the class. Sandra interpreted her instructor's approach and response as not caring about the students. While it may also be true that Sandra did not understand the content of her courses because she was poorly prepared, this response from an instructor did not encourage her to persevere. Sandra's description of her classroom experience illustrates her lack of preparation both for the coursework itself as well as for the different teaching styles she would encounter in a college environment.

In general, Carol believed her college classes were easier than her high school classes were. However, she did not demonstrate complete preparation for the academic demands and academic environment she would encounter in college. She described her biggest challenge as her struggles to meet the college's math requirements. She explained, "It doesn't come easy for me I have to struggle." But like other participants, Carol attributed these difficulties to her own lack of academic skills, not to poor preparation. In contrast, she did not believe she was prepared for the academic environment of college. She explained in her previous educational experiences she had encountered a regimented environment with many policies and procedures. She found 
college provided her with more freedom to develop and grow.

Bill was not prepared for the academic challenges or the environment he would face. He believed he was well prepared for the English requirements and enjoyed his English and History oriented classes. In contrast, he described having difficulties with meeting the college's math requirements. His struggles with math were so severe that he decided to audit a math class before taking it for a grade so he could "take the class and try and learn as much as I can before I take it again." Bill, like many other participants, did not attribute his struggles to poor preparation but instead to his lack of math skills. In addition to his academic difficulties, Bill was not prepared for the environment he would encounter at college. When he first began college he knew he would be in classes with students who were "half my age; that know nothing about life." However, he was not prepared to balance the demands of being a single-parent and attending college. In spite of planning to attend college, he did not arrange for somewhere to live and finances to pay for it before he began college. In addition, Bill explained he found it difficult to raise his son and help his son with his homework as a single-parent while trying to do his own school work. Bill did not believe he was prepared for the difficulties he would fact in juggling these demands.

Lenny, as Van T. Bui (2002) reported is common with FGCS, recognized he was not well prepared for college. He explained, “I didn't really think that I would be able to do all the academic work." His experiences demonstrate he was not prepared for the academic demands of college or the environment he would encounter at college. Lenny described struggling in reading and writing. In addition, as he discussed his college experiences, it became clear he also was not prepared for the academic environment of college. He described struggling with not knowing how to study and prepare for class. However, instead of attributing his struggles to his high 
school not preparing him for college, he took responsibility for them and explained he "wasn't a very avid reader."

While Ruth described being academically prepared for college, she did not demonstrate being prepared for the environment she would encounter in college. Ruth described herself as "rather studious" in high school and prepared for the academic demands of college. Although she was still prepared to meet the academic demands when she attempted college the second time, she experienced more academic challenges. College math classes proved to be more of a challenge when she returned to college. She explained, "I took college algebra after being out of school 30 years." In spite of experiencing increased challenges in Algebra, she still performed well and demonstrated continued academic preparation. The area in which Ruth was least prepared was in understanding the environment she would encounter in college. Ruth got married between semesters her first year at college. As a result of needing to cover living expenses, she decided to drop out of college after one additional semester while her husband continued college. At that time in her life, she was not prepared to balance the demands of her family life with those of being a student.

FGCS often do not have the opportunity to be informally exposed to the higher education environment (Fallon, 1997). The participants made it apparent they lacked this exposure and their educational institutions did little to help them learn about the environment. They often described not having a basic understanding of the demands of college classes and the academic environments they would encounter in college when they first entered college. Bill suggested colleges have more programs for FGCS to encourage them to continue their education and to get the help they need. He explained, "This is a shock to anybody that this is their first time." His preparation was so lacking that he had not arranged for somewhere to live when he began college 
and was homeless for his first semester. Sandra described struggling with professors providing multiple methods to solve problems and being frustrated at the different learning styles of other students. When Chuck first entered college, he struggled with setting an academic schedule while still meeting responsibilities at home. He also described the struggles he had in communicating with people who had different backgrounds than he had. Donna discussed difficulties in managing the technology she encountered in college. Each of these participants described difficulties stemming from their lack of knowledge of the college environment. They had not received knowledge about college in their prior educational environments. If they received help, such as Chuck did in how to communicate with others, it was on an individual basis but not through a planned institutional process.

FGCS are sometimes aware of their lack of knowledge about a college environment. Lenny and Ruth both suggested ways colleges could help FGCS be more successful. Lenny suggested college faculty and administrators need to do more to keep in contact with students and encourage them to continue. Ruth believed colleges need to do more to provide direction to FGCS.

The experiences these participants described demonstrated a lack of preparation through previous educational experiences on how to navigate the bureaucracy of the college environment as well as on how to be successful in their classes. Research has shown that FGCS often do not have the informal exposure to higher education (Fallon, 1997) where they learn how to navigate the higher education environment. Only two of the participants referred to high school education preparing them for college. The experiences these participants described demonstrate they were not prepared for the college environment in their previous schooling and received very little assistance in learning those skills at SCC. 
Academic assistance resources. Successful students need to have resources available to assist them when they face academic difficulties. The participants of the study reported a limited variety of resources to resolve their problems and mixed success in obtaining help. Five of the participants only referred to one or two resources for academic assistance. One participant discussed academic difficulties with former teachers and one referred to family and friends as academic assistance resources. The remaining participants sought academic assistance from campus offices and faculty. The participants of this study relied most heavily on campus resources to help them gain the skills they needed to be successful. All but one of the participants referred to using campus resources to obtain academic assistance. The participants relied most heavily on the academic support center, faculty, and other campus offices to learn the academic skills they needed.

One participant explained when he had difficulties in class he asked his former high school teachers for assistance. Lenny was most likely to seek help from his former high school teachers when he had difficulties in classes. His former teachers helped re-explain the material so he would understand better. He explained, "They just show me how to do it and they basically just put it in a way that I would be able to understand it easier.”

Chuck described using the widest variety of resources when he had difficulties in his classes. When he struggled in his classes, Chuck sought assistance from instructors, tutors, his mother, and a friend. He found all of them to be very helpful. Chuck explained his writing teacher did a very good job of explaining and making corrections to student work without communicating in a demeaning manner to students. He was also very pleased with the amount of one-on-one help the college provided. In addition, Chuck reported seeking academic assistance from his mother and a friend. Each of the resources helped him by re-explaining the materials so 
he was better able to understand.

Bill and Carol found they were more successful when they sought assistance from one of the college's tutors. Bill seldom sought help from others when he had difficulties in his classes. He described being very reluctant to seek help from others. In his day-to-day activities, his personal philosophy was “I don't need nothing from nobody around here. I don't ask favors from nobody." However when he did seek help, he found the college tutoring center and friends the most helpful. The tutoring center and friends helped by re-explaining and reviewing the material to help him understand class material better. He explained, 'I'm slowly picking it up. But it's just going to take time."

Carol found the most success in addressing her academic difficulties when she asked one of the college's tutors for help. The tutor from whom Carol sought assistance was a part of a program for low-income and first-generation students as well as individuals with disabilities. This tutor did not require scheduled appointments and worked with any student who asked for help. In describing how the tutor helped her, Carol explained:

She explains, she breaks it down in a very easy kindergarten-here-it-is way. She does an amazing job of simplifying. I mean she has no idea what you walk in with but she looks at it and gets it.

Two of the participants reported turning to faculty when they needed help with academic difficulties. Ruth was successful in these attempts while Sandra was not. Although Ruth was aware of other resources on campus, she typically sought academic assistance from her instructors because she was most successful with that approach. Faculty helped Ruth clarify information and understanding the pattern of information she was learning. When asked how talking to faculty was beneficial Ruth explained: 
Clarification probably would be the easiest way to say that. Just because I do read a lot and learning was not a big issue for me. So if I ran into anything, it was usually just I'm having trouble fitting this with everything else, where is this going, or how do I need to look at this differently?

Donna found a great deal of success by asking the faculty and library employees for help. Faculty helped Donna by providing clarification on assignments and other class materials. Staff helped her access the information she needed for classes and to develop ideas for assignments. When Donna first began college, she did not know how to use computers to access class notes and information. The employees showed her how to access the information. The next semester, Donna enrolled in a computer class that helped her learn computer programs. She explained:

I thought it would be very beneficial. And you know what? It was the best decision of my life because I had a fabulous teacher and I got in there and I learned all the programs. It was what I needed. Because, the classes I took after that, if I hadn't taken the computer course I would have been totally lost.

Sandra reported using the least resources to address academic difficulties. She was unsuccessful in obtaining help from a faculty member when she was struggling in a class. When she asked the faculty member for assistance, the faculty member advised her to drop the class if she could not understand the content. After that unsuccessful attempt, Sandra sought assistance from her advisor. Her advisor did not help her with the academic content but Sandra believed her advisor helped with her college experience by advising her she would not need the class. Sandra explained:

I went to one teacher and when she didn't help me I went to my academic advisor and she told me once again, if you don't think you can do it and if this teacher's not willing to 
work with you, you don't actually need this class, so you can drop it. So, that's what I did.

Developmental coursework. When students do not have the skills necessary to be academically successful, they sometimes enroll in remedial or developmental coursework (Horn \& Berger, 2004; Kazis \& Liebowitz, 2003). In contrast to other research about FGCS (Duggan, 2001), only two of the participants described experiences with developmental courses. Chuck, Sandra, Carol, and Donna all received high enough scores on the placement tests that they were not required to take remedial classes.

In accordance with reports from Humphrey (2002), Bill knew he was not strong in math and his placement tests supported his conclusion. He took a remedial math class the semester prior to participating in the study and reported he "still didn't do that good." As a result, he audited another math class the semester he participated in the study. His intent was to sit through the class and try to learn as much as possible without getting a grade for it and then re-take the class for a grade. He explained, 'I'm auditing the class this semester so that it won't count on my transcript." The second student, Lenny, said he did not take a remedial class but upon further discussion revealed he had taken one but was not aware it was a remedial class. One other participant chose to take lower level classes than those the placement test indicated she should take. Although Donna performed well on her placement tests and was not required to take any remedial classes, she was not confident of her math skills and in describing the results of her Algebra test she said, "I felt like I got lucky." As a result, she chose to take a lower level math class than she was required to take. She explained, "They were trying to put me in intermediate. I said no, I have to go back to the very beginning."

Interaction with faculty, staff, and administrators. Students' satisfaction with their 
opportunities to interact with faculty has a positive impact on their decision to continue their educations (Graunke and Woosley, 2005). The participants described a number of out of class interactions with faculty as well as out of class interactions with staff and administrators on the campus. The frequency of the participants' interactions with faculty and staff varied from one participant to the next and ranged from often to seldom. However, even those participants who interacted often with faculty and staff often did so to address specific academic needs.

Lenny, Donna and Ruth described frequent interactions with faculty, staff, or administrators. Lenny was more likely to interact with staff than with faculty. Although he described interacting often with staff, he seldom interacted with faculty. He explained he typically interacted with staff one or two times a day and faculty once a week.

Donna and Ruth were more consistent about their frequency of interactions with faculty and staff. Unlike Lenny, they reported many interactions. Donna described interacting with faculty once every week or two and with staff multiple times a week the previous semester. Although she reported interacting frequently with faculty and staff, her conversations focused on addressing specific academic needs. Ruth reported frequent interactions with staff and faculty. She described interacting with them at least on a weekly basis.

The other participants did not interact with faculty and staff as often. Carol, Bill, and Chuck described seldom interacting with faculty and staff. Carol reported she did not interact with the college's faculty or staff outside of class. She did not believe she had the opportunity to interact with faculty and staff outside of class. She explained, "I live an hour from here." As a result, she was on campus to take classes then left. Bill interacted with faculty and staff outside of a classroom only enough to say hello. He explained:

Now if I see them walking, I'll say hi to them. If I see them at Wal-Mart, I'll say hi to 
them. But I'll leave it at that, general courtesy, that's about it. It's just like I said, it's that military training. I consider that fraternization.

The only exception to Bill's personal policy was his interactions with his landlord who happened to also be a staff member at the college. Chuck seldom interacted with faculty or staff. He reported not interacting with faculty at all. He explained he interacted with staff when he saw them at church.

Based on their responses, all but one of the participants demonstrated they were integrated into the academic system of the college at least to some extent. Sandra described the most difficulty with academic performance. Although she took steps to be more academically successful she still described struggling in classes. This demonstrated a possible lack of match between her skills and needs with the academic characteristics demanded by the college.

Attribution of success. The participants of the study attributed their successes to a variety of factors. Several of the participants believed their successes resulted from personal characteristics and others attributed their successes to other sources.

The personal characteristics the participants referenced included dedication, hard work, determination, perseverance, and desire to learn. Donna believed she was successful because she worked hard and studied. Bill attributed his success to his dedication and perseverance. He believed his father taught him general life skills that helped him to be successful in college. He explained, "He taught me to be disciplined, self-disciplined, to be honest with people, honest with myself. Some of the stuff that he taught me you wouldn't think can help you in a college setting, but it does." Lenny attributed his success to his desire to set a positive example for others including his siblings. He explained, "You can't tell yourself that 'hey I'm not a college type person' because you never know until you try it. So I have to just encourage them to go to 
college." Ruth attributed her success in part to personal characteristics. She believed her personal characteristics of perseverance and desire to learn contributed to her success. Chuck attributed his success to his outlook and determination. He explained the more he was told he would not be able to achieve something, the more determined he was to be successful at it. He believed his positive outlook and determination helped him be successful, "I always keep the mindset that I'm the best, not in a conceited way, but nobody's better than me. I would rather fail and know that I tried." When he had difficulties, Chuck reported he found ways to motivate himself. He explained, “I'm the kind of person that likes to rub stuff in people's faces. I like to say, see I told you so."

Other participants credited sources other than themselves for their success. Although Ruth attributed her success in part to personal characteristics, she also credited her employment circumstances. She believed if her employer had not been as supportive of employees improving themselves, she would not have been successful in college. In describing the importance of a supportive work environment along with personal characteristics she said, "It's kind of like that three-legged stool, you could never have just one." Sandra attributed her success to the support of the college. She explained, "If it hadn't been for the school and everything that they have done for me, then I wouldn't be where I'm at now." Carol believed she was successful because of the motivation her daughter provided. She explained her daughter motivated her to be successful because "I want to give her better."

Social involvement and integration. A second area Tinto (1993) also identified social integration into college as critical to student persistence in college. According to Joseph (1995), a key component of students' persistence in college is the degree to which they are integrated into the social system of the college. For the purposes of this study, students' comfort level on 
campus, reported social challenges, and amount of out-of-class interactions with peers were used to understand how socially integrated students were.

Comfort level. The participants of this study described themselves as comfortable on the SCC campus. They referred to their comfort in terms of positive experiences with community members and a supportive campus atmosphere. When asked directly if they were comfortable on campus, all of the participants said they were.

Many of the participants attributed their comfort to the nature of the members of the campus community. Chuck found the campus to be very "laid-back" and believed everyone on the campus "gets along." He explained he was "almost as comfortable as I am at home." Lenny attributed his comfort to the opportunities he had as a part of the campus community to get to meet new people and become friends with different people. Carol explained the members of the campus community made her feel comfortable. She explained, "They make it really comfortable for you. I mean even the business office and financial aid office, and even the lunch ladies; they're great."

Donna described a very different experience at SCC than she encountered on other campuses. Her experiences at SCC were in direct contrast to her experiences with other institutions. When she was considering attending college and spoke with people at other institutions. Donna described her lack of comfort on those campuses, "They just kind of give you this information and then you just kind of have to go find out the rest yourself." When she began exploring programs at SCC, Donna noticed the difference between members of the SCC campus community and members of other campus communities. She explained, “There hasn't been anyone that I haven't been able to go to and them not help me.” She found members of the SCC community so helpful that she continued to approach them for assistance and advice even after 
she was admitted to her program.

Ruth attributed her comfort level at SCC to the atmosphere of the campus. She described always being comfortable when she was around an educational environment. In spite of that comfort, she never anticipated working in the environment. However, once she began taking classes at SCC, Ruth believed the atmosphere of the campus led to her comfort at the college. She explained, "The attitude here on campus is very encouraging to commit toward completing your education."

Sandra and Bill described being the least comfortable at SCC. Although Sandra was not uncomfortable on campus, she did reference having negative experiences. She explained, "It's been okay. It's not like it's been bad. I just have had a few bad experiences. I dropped it and went somewhere else. I just carry on, find something else to do." When he first arrived on campus, Bill also found it difficult to be comfortable. However, his lack of comfort was not related to the campus itself as much as his living conditions. He reported he did not feel comfortable his first semester on campus because he did not have anywhere to live. However, once he found a place to live his comfort level on campus increased.

Social challenges. The participants' degree of social integration was demonstrated by the number of challenges they experienced. The participants referenced experiencing few social challenges. They credited the open and friendly nature of the members of the campus community for not having social challenges.

Sandra, Lenny, Ruth, and Bill all explained they did not have any social challenges. Ruth attributed her lack of challenges to her personality. She explained, “I don't think that's really been an issue for me. I'm pretty much self-motivated. I guess you might say I'm an introvert. So I don't really need people so much to tell me what works and what doesn't." Bill also attributed 
his lack of social challenges to his personality. He explained:

I'm honest with everybody around here; I tell it like it is. If it hurts your feelings, I hate it for you.... Some people say I'm too brutal with my honesty. Maybe I am but... I'm not going to lie to you. I've got some friends around here they understand that's the way I am. They accept that. Most of them love me for that.

Donna, Chuck, and Carol referenced having some social challenges. Donna explained her biggest challenge was not having as much personal space because she moved out of her home and lived with a family member while attending college. Chuck described his biggest challenge as learning how to be more open-minded to differing opinions. He described himself as a strong supporter of America, but believed some people do not like America and do not like living in the United States. When he arrived on campus, he had to learn to respect others' opinions even if he did not agree with them.

The few social challenges that Carol faced were related to her major. Because she often was the only female in her classes in a program that was a male dominated field, she initially struggled with being treated differently because of her gender. Not only did she have to contend with sexual comments, the males in her classes often did not believe she would be able to handle the work in the class. She largely credited her instructor for ensuring the behavior stopped and for setting a positive example for her classmates. She explained:

I had a couple of guys at the end of my 2004 semester that sat down and said Carol, 'You being in this class has really changed the way we look at women because my girl cousin used to beat me in basketball and I used to say oh, I just wasn't playing very good today. Now I know that it's not that way.' Because I could break loose things that they couldn't. I was tougher than they ever imagined. 
Interaction with peers. The participants' interactions with other students and involvement in campus organizations and activities were connected to their comfort levels on campus. Although two of the participants reported seldom interacting with their fellow students outside of class, other participants reported they did so regularly. Even though the amount of participation they described varied from one participant to the next, almost all of the participants took part in organizations or activities.

Several participants described frequent out of class interactions with students. Sandra described interacting outside of class with students on a daily basis. However, her interactions were limited to two other students one of whom was a friend who was in all of her classes. Chuck described interacting frequently with other students. Because many students lived in the same apartment complex as he did, he saw them on an informal basis quite often. Lenny described interacting with people from the campus community on a daily basis. However, he explained, "I never know who I might see at the school and who might be a student." Bill's pattern of interaction with other students changed after he entered college. He reported interacting with other students on a regular basis his first two semesters on campus. However, once he found somewhere to live that was a long distance from campus, he did not have as many opportunities to interact with others. He explained, "The only time I interact is if we've made plans to do so in advance." With that change in his living arrangements, he interacted with other students outside of the classroom only a couple of times each month. While he did not have structured out of class interactions with other students, Bill reported many casual greetings and interactions between classes.

Two of the participants, Donna and Carol, reported they seldom interacted with students outside of the classroom. Donna explained, “They're all younger than me and I don't have much 
in common with them." Carol explained she lived an hour from the campus so did not have the opportunity to interact out of class with other students.

Three of the participants described very limited involvement in student organizations and activities. Donna, Chuck, and Carol were not involved in any student organizations. Donna was initially interested in one student organization but decided against being involved because she believed her course load was too heavy. Like Donna, Chuck believed he did not have enough time to be involved in student organizations. Carol attributed her lack of involvement to the distance she traveled to and from college. She believed because she lived an hour away from the college, she was not able to participate in any student organizations.

The other four participants belonged to a limited number of student organizations. The organizations in which they were involved included and honor society for two-year colleges and programs, a religious organization, and a Multi-cultural organization. When she was a student at SCC, Ruth was a member of an honor society. After receiving her Associate's degree, Ruth continued her involvement in the organization as an advisor. As she pursued advanced degrees at other colleges, she was not involved in organizations affiliated with those colleges. Lenny described being involved with two student organizations. Bill was a member of one student organization and occasionally attended meetings for a second organization. Sandra described participating in two student organizations. She attributed her lack of involvement in student organizations to limited opportunities. She explained, "That's all they have here.”

Although they were not extremely involved in student organizations, the participants each described participating in student activities to some extent. They described participating in a variety of social events such as cooking contests. When Ruth pursed her Associate's degree at SCC, she was involved in student activities but was not as she pursued her Bachelor's and 
Master's degrees at other colleges. In spite of their limited interactions with students through student organizations, Donna and Chuck both participated in various student activities on campus. Chuck participated in student activities because he provided technology support to them for his work-study position. In the past, Lenny had only participated in meetings for those organizations in which he was a member but during the semester in which he participated in the study, he was attempting to attend more student activities on a wider variety of topics. Bill reported being the most limited in his involvement in student activities. He explained he limited his involvement in activities because "If I feel is going to interfere with me studying or whatever, I probably won't or if I've got my son, my son comes before anything." Each of the participants demonstrated they were socially integrated to some degree into the campus community. They described interacting with other students out-of-class through informal means or through membership in student organizations and participating in student activities.

Support. For many FGCS, finding support through social networks proves challenging. However, all but one of the participants of this study reported some support. They described a wide range of sources of support. Their sources of support were family, friends, and members of the community. Six of the participants described support from family members through pep talks, a place to live, and assisting with the financial aspects of college. Two of the participants described support from friends. Their support from friends included pep talks as well as progress and wellness checks. One participant referenced support from a community member. Another participant, Sandra, was originally encouraged by a family member to attend college but when asked about family support reported that she did not believe any of her family cared if she was making academic progress.

Bill described receiving a great deal of support for his college endeavors. He referenced 
support from instructors, the veteran's representative, and some friends he had made after beginning school. They helped provide him motivation and pep talks when he struggled with the demands of college. He also was supported by his landlord. He described his landlord as supportive by being flexible about when Bill paid rent. The support he garnered from members of the campus community was critical for him because his family lived far away and was not able to provide day-to-day support for his endeavors.

Lenny received support from family, friends, and members of his church. He explained all of his family and friends were supportive of him attending college. When he needed help his church provided him with encouragement and motivation. He described his biggest supporters being his grandmother, brother, and sister. His grandmother told him how much she wanted him to attend college and his brother and sister were motivation for him to set a positive example. However, Lenny believed members of the college community could help FGCS be successful by "keeping contact with them because they kind of see themselves as not being able to do it" and encouraging them to continue their education.

Donna received a great deal of encouragement when she decided to pursue a degree. She put many of her belongings in storage and moved to the community so she could attend college. Her aunt told her to "Put your stuff in storage and come on, come and see what you can do here." She received further encouragement from cousins, children, and friends. She explained her son was her biggest supporter and encouraged her, provided her with feedback, and told her he was proud of her.

Chuck found a great deal of support from members of the college community, friends, and family. His college advisor and other staff helped him adjust to interacting with people who had different backgrounds then he did. They provided him tips on how to interact better with 
other students and got him involved in groups to get to know other students. A friend checked on Chuck on a regular basis to make sure he did not need anything and was getting to classes without a problem. Chuck explained his mother "supports whatever I want to do as long as it's productive." With his mother's concern that he pursue something productive came initial criticism for attending college. Members of his family questioned his reasons for attending college but once convinced his reasons were centered on increasing his educational level and obtaining better career opportunities, they became supportive.

When Ruth had any difficulties, she was able to seek assistance from co-workers or more advanced students. They provided assistance by describing how they addressed similar problems or concerns. She explained, "We have a lot of people here who are employed who have gone through the same type of programs, so we have our own built in structure of support." In spite of this support, Ruth listed her children as her biggest supporters. She described her children as motivating and encouraging her. She explained, "I actually walked for graduation with my middle child, for my Associate's degree.”

Sandra found support from her college advisor and her children. The college advisor helped her find the correct answer to her problems so she could start college. Sandra referred to her children as her biggest supporters. She explained, “every time I look at them it just makes me want to do it more. They've given me the support I need to go every day, to get up and go.”

Carol described her biggest supporter as her instructor. She explained he was supportive because, "he doesn't treat me differently, accepts it, and he challenges me, he expects a lot for me pushes me." Although she reported feeling supported, at times she experienced criticism for her college endeavors. Family questioned her career choice because she was studying a nontraditional career for women. In addition, when she struggled financially, a family member 
encouraged her to leave school and focus on getting a full-time job. Carol believed colleges could help FGCS by being aware of the struggles they are facing. She explained, "Once you move up, you forget what it's like to struggle and are not as compassionate towards that struggle."

Tinto (1993) emphasized the importance of students being integrated into the social system of a college and interacting with their peers at college. The participants in this study described support not only from the college but also from family and significant others for their pursuit of a college education. Their responses supported Tinto's findings only in part. They described relying on a wide range of sources for their support that extended beyond the college.

Financial resources. Even after students begin college, they must continue to obtain financial resources in order to pay for college. SCC offers a number of programs to help students meet expenses related to pursing a college degree. These programs include federal aid through grants and loans; state aid through scholarships, grants, and loans; and institutionally funded academic scholarships.

In addition to its many programs to help students meet their financial needs, SCC has limited reliance on student tuition and fees to meet its budget. Student tuition and fees contribute only $11 \%$ to the college's overall operating budget. In total, almost $80 \%$ of the college's expenses are met by non-capital resources such as gifts and grants to the college. Gifts and grants alone defray $22 \%$ of the college's operating expenses. More than half of SCC's expenses are met by state appropriations. However, students' tuition and fees along with property and sales taxes contribute to a small portion of SCC's overall expenses. Property and sales taxes account for less than $6 \%$ of its overall expenses.

To help students address the cost of seeking college educations, Southern Community 
College provides students access to various state assistance programs. One such program provides financial assistance for students who are in their first year of college and are certified as drug free and maintain a 2.0 grade point average. Another state funded grant is earmarked for non-traditional students who demonstrate unmet needs from federal programs each year they are eligible.

In all, the college provides institutional scholarships that total nearly one quarter of its overall operating expenses. The college provides scholarships based on various criteria which include: high school performance, high scores on national aptitude tests, GED scores, field of study programs, transfer status, student status, college performance, recommendation from program facilitators, unmet financial need, county and state of residence, and graduation from specific regional high schools.

The participants continued to describe very limited finances at their disposal. As a result, they relied very heavily on financial aid to meet the financial demands of attending college. However, the participants seldom referred to obtaining student loans that would place them in long-term debt. Instead, they most frequently discussed obtaining money through methods that would not lead to long-term debt. The participants relied very heavily on grants and other financial aid programs that did not require repayment. In addition, the participants met their expenses by reducing their living costs and obtaining employment.

A main source of finances for the participants was financial aid. Almost all of the participants received some sort of financial assistance to pay for college. Chuck described a high need for financial aid programs to make it possible for him to pursue a college education. He explained, “I was broke when I came to school. I didn’t have money for books.” When discussing her biggest financial challenge, Carol said, "It's all a challenge right now." The 
previous year she struggled financially to the extent that she had difficulty paying for food and living expenses for her daughter and herself.

Each of the participants described financial aid as an important aspect to being able to seek an education. When Ruth first entered college, she received a scholarship. She explained, “If it hadn't been for the scholarship, I would not have even begun college after I graduated high school. I wouldn't have been able to.” Even when Ruth returned to college 30 years later, she relied on her employee's tuition discount in addition to Pell Grants to attend college. When Donna first began college, she received unemployment benefits, grants, and loans that helped defray the costs associated with attending college. Lenny relied on the G.I. Bill in addition to financial aid programs to pay for college. Access to a career development program that helped pay for books in addition to financial aid that paid for classes and low-income housing assistance for her family made seeking a college education possible for Sandra. Carol relied on Pell Grants, a career development program, and loans to cover her financial expenses. Bill described managing his financial needs through the G.I. Bill, disability benefits, and Pell Grants.

Despite receiving financial assistance, the participants of the study struggled to cover living expenses in addition to paying for college. Ruth explained, "I could see how someone who doesn't get a discount would have a very hard time taking more than one class at a time." Donna's unemployment benefits ended before she finished her degree. Although Chuck knew his military benefits would cover his classes, he was not sure how to pay for supplies for his classes. As a result, he sought additional sources of finances. In spite of receiving financial assistance through the G.I. Bill, disability, and Pell Grants, Bill had to monitor his expenses very carefully. While Bill was financially stable at the time of the study, affordable housing had eluded him for a while. He explained, "If I manage them right, I'm good to go. If I mess up, I have to go to the 
pawn shop, which I've done a couple of times." Carol experienced such financial difficulties that she decided to take out a student loan to help cover her expenses. She explained:

It's the only way that I could manage to afford to come. I have her [Carol's daughter] at night so there's nobody else, so I can't work a night job and go to school during the day so I had to, it's the only thing I could come up with.

Although the participants received financial aid through college, none of them found their financial aid eliminated their financial challenges. Each of the participants alluded to some sort of compromise or sacrifice they had made in order to make attending college possible. When Ruth first attempted college, she dropped out of college in order to pay for living expenses. When she returned to college, she worked a full-time job while attending college in addition to receiving additional financial assistance to pay for living expenses. When Donna's unemployment ended, she began working to earn the money she needed. This additional time commitment reduced the amount of time she had available to study and prepare for classes. Lenny joined the military not only to obtain military benefits to pay for college but also to have something to fall back on if he was not successful at college that would still allow him to "make something" of his life. In addition to the financial assistance Sandra received, she worked 25 hours a week to earn extra money for living expenses. Carol commuted more than an hour each way to take classes. Every hour she spent in class and commuting, she believed she should be working to cover the expenses of being a single parent. However, she said, "My other choice is working at Mickey D's and never get anywhere; so I can suffer through these two years and hopefully be able to not ever to live like this again."

Financial advice. In addition to their challenges in obtaining money for college, the participants referenced few resources to advise them on how to address their financial challenges 
other than through financial aid programs. Only two of the participants referenced receiving financial assistance from family members. They all reported seeking assistance from campus offices such as the college's Financial Aid Office and the Veteran's Administration Representative.

Donna, Lenny, Chuck, Carol, and Bill all described being successful in obtaining help from members of the campus community although they may also have sought help from other sources. When Donna needed assistance, she approached the Financial Aid Office. The office helped her complete the paperwork she needed and identify resources to pay for college. Lenny sought help from the financial aid office and the veteran's representative to complete his paperwork and apply to programs for which he was eligible. When Chuck needed assistance, he sought help from a college staff member. This staff member was not a part of the financial aid office but helped him complete the paperwork he needed and identify resources for which he was eligible. When Carol needed financial assistance, she worked with staff in the financial aid office. Until the previous year, Carol also typically talked to her grandmother when she needed help. She explained:

I could tell her exactly the reason and why and she, wouldn't sugarcoat it, she loved me no matter what and she would honestly just give me what I needed to hear. So that's who I went to. Everybody else would be biased and would just tell me to quit.

Bill initially said he preferred not to ask others for their assistance when he needed help with his finances. He explained, "Nowhere. I do it; I take care of my own. I'm a private person." However, he reported he did speak with the veteran's representative at the college. The representative helped him access his G.I. Bill and the Pell Grant so he could begin college. Although Sandra reported initially seeking help from the financial aid office, she did not 
describe being successful in obtaining help. Hughes (1990) found a significant correlation between students' satisfaction level with the financial aid office and whether or not the staff made the students feel comfortable. When Sandra needed financial help, she sought assistance from the financial aid office. However, she expressed dissatisfaction in her experience with the Financial Aid Office. She explained, "They gave me the runaround; tell me that I had to get this paper, and fill this out, and bring it back, and then wait, come back."

Goals and commitments. Tinto (1993) emphasized the importance of students' commitment to their education in their persistence in college. Regardless of their reasons for beginning college, all seven of the participants had developed educational goals and were committed to meeting their goals. Their commitment to their education could be traced through their continued goals of attending college, satisfaction with and commitment to their college and programs, and desires to complete degrees in timely manners.

Post-entry goals. Each of the participants maintained a commitment to reaching their educational goals. One of the participants, Sandra, planned to earn an Associate's degree. Lenny, Chuck, and Donna considered pursing a Bachelor's degree after earning Associate's degrees. Carol and Bill planned to earn Bachelor's degrees. Ruth had progressed to working on a Master's degree.

At the time of the study, the participants were all committed to completing their educational goals. However, all but one of the participants altered their goals to some extent between beginning college to when they participated in the study. Four of the participants changed their goals to ones that required more education, one changed her program to one that required less education, and one pursued goals requiring the same educational level but in a different career path. The final participant maintained the same goals. 
The majority of the participants made changes to their goals which required more education. Chuck, Lenny, Carol, and Ruth all set new goals after they began college that required more education. When Chuck first began college, he wanted to earn an Associate's degree as an EMT or paramedic to prove to himself that he could do better academically than he had done in the past by dropping out of school. After beginning college, he considered potentially continuing his education and earning a Bachelor's degree. Chuck believed more education leads to more opportunities and people need as many opportunities as possible.

Lenny planned to earn a certificate and maybe take basic classes in case he later decided to pursue a Bachelor's degree elsewhere when he first began college. After entering college, he decided to increase his educational level. At the time of the study, he had decided to earn an Associate's degree in a field related to his certificate and to potentially transfer to another college for a Bachelor's degree.

At the beginning of her college pursuit, Carol's goal was to "complete the program [in diesel mechanics] and get a kick butt job.” However after beginning college, she faced more challenges than she originally expected. Although her goal of earning an Associate's degree had not changed and her field of study had not changed, at the time of the study she hoped to pursue a Bachelor's degree in another field. Carol considered earning a Bachelor's degree in another field as a result of her personal interests and to be more "well-rounded."

When Ruth originally began college, she planned to earn a Bachelor's degree and teach physical education. However, upon her return to college 30 years later, she changed her field of study to human resource development and adult education. In addition, she decided pursue a higher educational level by earning a Master's degree. The changes she made to her goals were the result of changes in her life such as getting married and raising children as well as her job 
sparking new career interests.

Sandra entered college with plans to be a wedding planner and photographer and then earn a Bachelor's degree in business. However, SCC did not offer the programs in which she was interested so she earned a certificate in nursing and began pursuing an Associate's degree in nursing. Once she started the program, she decided to make another change to pursue a degree in medical office management. She changed to medical office management because she did not believe her instructors provided enough instruction for her to understand the materials and be able to earn an Associate's degree in nursing.

When Donna entered college, she struggled to make a decision between pursing a nursing degree and a respiratory therapy degree. Because she had difficulty obtaining information about the respiratory program and the start date for the respiratory classes would have delayed her entry into college, she entered college for the nursing program. After she began taking classes, she decided to pursue the respiratory program instead. The change to the respiratory program more closely aligned with her interests. Her new program required the same educational level but had a different focus in working with patients.

Bill was the only participant who maintained exactly the same goals. When Bill first began college, he planned to earn a Bachelor's degree and his goals had not changed. He explained:

When I was in high school and middle school and all, I didn't like the history teachers because, I always felt that, one they didn't know what they were talking about, they were giving out wrong information, and they had no passion about it. I want to change that. Some participants had specific career aspirations while others had goals that were more general in nature. Donna, Chuck, Bill, and Ruth were specific about how they wanted to use their 
degrees. Donna specifically wanted to work in respiratory therapy. Chuck reported he had been in the infantry and thought he had figured out how to kill people so now he wanted to learn how to heal them while working as an EMT or Paramedic with a fire rescue service in a large town or on a search and rescue team. Bill specifically wanted to earn the credentials he would need to be a history teacher. He explained, "I want to be a different, a better history teacher. I want to get the right information out there." Ruth planned to continue her career in Human Resources and her career was closely related to her academic studies. She explained, "What I realized after getting into that program is that it was perfectly aligned to everything I do already in my job. It was kind of like it made my schoolwork easier, but also enhanced my job at the same time."

Two of the participants, Lenny and Carol, had general goals for using their degrees. Lenny was very uncertain about how he would use his certification and degree. He explained his goal in earning an education was to obtain "A good paying job where I can be certified in it." Carol also was not specific about how she wanted to use her Associate's degree. Like Lenny, her focus for getting a degree was to improve her job opportunities. As she finished her program, she considered accepting a job she had already been offered. The job was in a field related to her degree but not an exact match to her degree.

Post-entry commitment. Research has demonstrated students who are committed to an institution or program are more likely to persist (Bers \& Smith, 1991; Tinto 1993). The participants of the study reported they were committed to the college as well as to their programs of study and were satisfied with the quality of education they received at SCC. The participants all reported they would reenroll at SCC if they had to make the choice again. Some indicated they would do so because of its location and convenience but others referred to the employees and academic programs as motivating them to re-enroll. 
The reasons the participants gave for choosing to re-enroll at SCC included its location, the quality of academic programs, and the atmosphere of the campus. Bill, Sandra, and Ruth all reported they would enroll at SCC at least in part because of its location. Bill explained, "It's the only school here and I don't want to drive all over God's creation just to get to school." Sandra shared his sentiments about the location. She explained, "Because it's the only one" and "I'm not driving nowhere else to go to school." Ruth explained she would re-enroll at the college because of the convenience of taking classes where she worked.

Other students specifically cited characteristics about SCC that would lead them to reenroll at SCC. These characteristics included the quality of their educational programs and the atmosphere of the campus. Carol explained, "I just I don't like the bigger institutions that just could care less. I mean, these people know me by name." Donna said she would re-enroll at SCC because, "I think the teachers are very good." In addition to the quality of academic programs, several of the participants cited the atmosphere of the campus as a reason to re-enroll. Carol described SCC as having a "good, home, family feeling." Donna explained she would re-enroll at SCC because "I could go to anyone and ask for assistance and everyone helps. Chuck described the teachers at SCC as "more than helpful." He described the faculty and staff on the campus as "great" and said he could not ask for a "better support channel." When asked if he would re-enroll at SCC, Chuck responded "Yes, again 100 times." Lenny described the campus as friendly, "not too big, not too small." He explained, "It's a campus that you can come to and feel like you know everybody from the first time that you see them to the end of the semester."

All of the participants would choose the same program or major if they had to re-enter college. Bill explained he would re-enroll in the same program because "It offers me history. Anything that would offer me history I'm definitely going to stay with." Carol would re-enroll in 
the same program because it was a field she enjoyed. She explained, "It's something like to do. I like to tear things apart and try to put them back together." In addition, she would choose the program at SCC because "They have the best diesel program in the area." Chuck said he would pursue the same program because "I just like helping people. It's something that I know; something that I'm good at; I'm people friendly." Donna would have enrolled directly in the respiratory program she was in at the time of the study instead of beginning the nursing program because she believed the respiratory program was a better fit for her interests. Ruth explained she would enroll in the same program she earned her Associate's degree in because she wanted a program that would transfer to a Bachelor's program. After she enrolled in the program, she discovered it not only met that need but also "was perfectly aligned to everything I do already in my job. It was kind of like made my schoolwork easier, but also enhanced my job at the same time." Lenny would enroll in the same program because he believed the program allowed him to learn new things. He explained:

They keep me as a person going. I'm the type that likes to learn new things, learn and gain experience because there's something I might run into, something dealing with the class later on in life and I can say hey I took a class on that, and I know how to fix this and fix that. There might be somebody else, they don't know what they're doing, I can tend to help them out.

Although Sandra would have re-enrolled in the same program, she was less enthusiastic about it than the other participants were. She explained, "It would be one of the only programs that they have that I'd be interested in. They don't have very many."

The participants demonstrated they were committed to completing their programs in a timely manner with their student statuses. Cofer and Somers (2000) reported students enrolled as 
full-time were more likely to persist. Six of the seven participants were enrolled as full-time students. Bill reported taking the most hours at16 the semester he participated in the study. Donna was the only participant enrolled on a full-time basis who typically did not do so. Her enrollment status varied from semester to semester depending upon the demands of the courses. She typically enrolled in two classes per semester. However, she enrolled in classes year round so within a year, she completed the same number of hours as students who took a full-time load in Fall and Spring terms. Ruth was the only participant who reported being enrolled on a parttime basis. She explained she typically enrolled as a part-time student, "because I obviously have a full-time job." Although Ruth was not enrolled as a full-time student, she demonstrated continued commitment to completing her program. She enrolled on a part-time status since returning to college and had progressed to seeking a Master's degree.

The likelihood of students remaining in college increases as students' progress through their programs (Horn \& Berger, 2004). All of the participants expected to complete their programs within six months to two years. One characteristic that was common to most of the participants hinted at the possibility the participants could have difficulty in completing their educational goals was the amount of time and effort they expended on studying. Terenzini et al., 1996 found although FGCS are not academically prepared for college and gain more than their non-FGCS counterparts gain by studying, they are less likely to do so. Although six of the seven participants were enrolled on a full-time basis, their average amount of time studying per week was only 9.5 hours. Their actual study time ranged from two to 20 hours a week. Lenny reported studying the least amount of time per week but was in his final semester of his program. Sandra reported she studied "at least seven" hours a week. Chuck and Carol typically studied approximately 10 hours a week. Donna's amount of studying varied depending on the demands 
of her classes but she typically studied 15-20 hours per week. Ruth explained when she was in class full-time; she typically studied 12-18 hours a week. Bill's amount of study time also varied based on the demands of his classes. However, he reported he typically studied approximately 20 hours a week. He explained, "It would be all factored together. I mean I try to make time to study for everything but I mainly study for the day ahead." 


\section{Chapter 7: Summary, Conclusions, and Recommendations}

This chapter begins with a summary of the institutions participating in the study; the study's purpose, research questions, and methodology; and continues with a summary of the major findings of the study. The chapter resumes with a summary of the findings as they relate to the participants' pre-college academic preparation, financial resources, social support; and goals and intentions for attending college. Then the chapter presents a summary of findings related to participants' academic and social integration into college, their financial resources and goals in continuing their educations, and commitments to completing their educations after they begin college. The chapter ends with implications for action and recommendations for further research.

\section{Summary of the Study}

The primary postsecondary option for first generation college students (FGCS) has been and continues to be community college. FGCS are those students who are within the first generation of their family to seek postsecondary education. Nearly one quarter of the students who entered college between 1992 and 2000 were FGCS (NCES, 2005a). Research has identified key challenges that FGCS face in their attempts to seek a college education. These challenges include lack of social support, financial knowledge, and academic preparation (Horn \& Berger, 2004; Horn \& Nunez, 2000; Terenzini et al., 1996). Research indicates FGCS tend to have few friends, family, or mentors available to discuss potential problems and to help develop solutions for issues regarding entry into college and completion of degree programs (Horn \& Nunez, 2000). Furthermore, the research indicates FGCS are more likely to come from lowincome families and are less likely to receive financial support from their parents (Nomi, 2005). FGCS are more likely to work part-time or full-time while attending college (Humphrey, 2000; Nunez \& Cuccaro-Alamin, 1998). However, research indicates the more hours students work, the 
more negative of an impact it has on them (Hertel, 2002; Pascarella et al., 2004). In general, FGCS are less prepared to meet the academic demands of college (Van T. Bui, 2002). As a result of these challenges, FGCS not only face difficulty in entering college but also in completing degrees (Nunez \& Cuccaro-Alamin, 1998)).

Purpose statement and research questions. The purpose of this study was to examine how successful FGCS address the challenges they face in order to complete their degree programs. For the purposes of this study, success was defined as students who depart the institution as a result of completing a degree, program, or credential area or as a result of transfer to a four-year institution to pursue a bachelor's degree. The primary research question for this study was: How have successful first-generation community college students overcome their challenges in order to be successful? Other concerns related to the primary research question included why students enter college and with what goals they enter college; what challenges they face; and how they reflect other academic, social, and financial related findings in the literature on first generation students.

Review of methodology. Because the research on FGCS success at community colleges is still emerging, this study used qualitative methods. An advantage of using qualitative methods is that it focuses on the participants and acknowledges that there are variations in participants' experiences (Auerbach \& Silverstein, 2003). The nature of qualitative research means the findings of this study cannot be generalized to represent all FGCS. However, by using a qualitative research approach, I had the opportunity to explore the experiences of FGCS and gain a better understanding of their distinctive experiences in seeking an education. The overall intent of this study was to expand the knowledge base of what FGCS experience while in college in order to reduce the challenges they often experience. As understanding of the experiences of 
FGCS increases, colleges will be better able to address their needs and help them persist to graduation.

\section{Summary of Findings}

The findings in this study are essentially consistent with the findings in current research on first generation students with a few notable exceptions. In this section I present a summary of the findings as they apply to the framework of the study. I end the section with a discussion of the similarities and differences among the three sites.

\section{Pre-College Characteristics.}

Academic preparation. The participants of this study were prepared neither for the academic content nor the academic environment of college. Van T. Bui (2002), Terenzini et al. (1996), Fallon (1997), and others report FGCS tend to be unprepared for college. They lack the academic preparation as well as the informal exposure to college they need to have to be successful. The participants of this study supported these findings. Most of the participants demonstrated they were not prepared for the academic demands of college. In addition, many of the participants entered college without knowing what to expect from the college environment in or out of the classroom.

A few participants contradicted the many research reports that FGCS are not prepared for college (Chen \& Carroll, 2005; Horn \& Nunez, 2000; Humphrey, 2000; Terenzini et al., 1996). The experiences these participants described demonstrated they were prepared for the academic demands of college although that preparation may not have derived from previous schooling. There was not a consistent pattern to their reports. Two of the participants who reported scoring well on placement tests and earning good grades were high school graduates and one earned a GED. 
Even those participants who were prepared for the academic content of college were likely to struggle in college. A number of the participants demonstrated they were not prepared for the academic environment of college. The experiences they described supported Fallon's (1997) report that FGCS may miss out on informal exposure to the higher education environment others obtain by listening to significant adults talking about their college experiences. Some participants reported struggling with the level of responsibility students have for their own learning, not knowing how to function in a college environment, and not understanding how to manage different instructional methods.

There were participants of this study who described struggling with college in general. They struggled with academic content as well as the academic environment of college. Some participants had not taken the classes they needed to be successful in college and had not understood what the college environment would be like. These participants could not meet the academic requirements, did not understand how to use the technology required at the college, and did not understand how to access information on the campus.

Informal exposure to the higher education environment and availability of advice on what to expect in college are another area of weakness for FGCS. They often do not have the opportunity to be informally exposed to the higher education environment (Fallon, 1997) and often do not have sources to advise them on what to expect in college (Horn \& Nunez, 2000). The participants made it apparent they lacked this exposure and their educational institutions before and after they entered college did little to help them learn about the environment. Not only did their previous educational experiences fail to prepare the participants for college, once they entered college, they did not receive the help they needed to develop skills to be successful.

Financial resources. Horn and Nunez (2000) reported FGCS tend to have limited 
financial resources. The experiences many of the participants of this study described support those findings. Their lack of financial resources served as a major roadblock for many of the participants in pursuing college educations. Participants described struggling to provide food and shelter for themselves and their families as well as making personal sacrifices in order to attend college.

Finances were such a concern for some participants that their financial resources influenced the timing and location of their pursuit of a college education. One participant described delaying her entry into college because her family did not have the resources and she was not eligible to obtain financial assistance on her own (see Chapter 6). Several of the participants from two of the three sites entered the military in order to access the G.I. Bill, and other participants chose a college based upon the cost of attending, not on the programs being offered at the college.

Social support. Tinto (1993) found support plays a critical role in students' goals of seeking college educations. Non-FGCS are encouraged from a young age to attend college upon graduating high school. However, Horn and Nunez (2000) reported this is not often the case for FGCS. The experiences of the majority of the participants in this study are consistent with these findings. They were either not encouraged until they were adults to or not encouraged at all to attend college. However, a few of the participants' experiences contradict previous reports.

Several of the participants were adults or nearly adults before they were encouraged to pursue a college education. Their encouragement came from various people for different reasons. It came from family, teachers, and public service employees. For many of these participants, family members including significant others served as a major source of encouragement. The encouragement most of the participants received was for them to reach the goals they had set for 
themselves. However, a few of the participants were encouraged to attend college in general to improve their lives.

Other participants did not report receiving any encouragement at any point to attend college. Some of these participants did not have anyone present college as an option for them. One of the participants was actively discouraged from attending college. Each of the participants who had not been encouraged to attend college was self-motivated to attend college or found the encouragement to attend college by the examples of non-familial individuals around them.

In contrast to the experiences described by Horn and Nunez (2000) and those described by the other participants in the study, a few of the participants said they had been encouraged from a young age to attend college. One way these participants were encouraged to attend college was by family members doing things such as mentioning "how important school was." Other participants received encouragement from family as well as from members of the community. For some of them, this encouragement led to their attending college directly out of high school. However, even with their early encouragement, several of these participants chose not to attend college directly after high school. They waited for a number of years until they were self-motivated or encouraged again by other people in their lives.

Goals and intentions. The primary reason participants entered college was to increase their opportunities. Fallon (1997) reported FGCS often see the purpose of a college education as a means to a good job. As a result they may not be as involved in campus life and may not have a strong commitment to their role of student. The participants of this study supported these findings. They were less involved in campus life and spent much less time devoted to their roles as students.

Van T. Bui (2002) reported FGCS have a range of reasons for entering college. The 
primary reason is to obtain job skills according to the CCSSE (2005). The participants of this study were no different. They provided three main reasons for seeking college education: 1) a general desire to improve their job opportunities, 2) to set positive examples, and 3) to achieve personal goals. For most of the participants, their reasons for attending college were a blend of the three.

One of the reasons participants gave for entering college was a desire to improve their opportunities. For many of them, improved opportunities meant they would be able to obtain better jobs than they would be able to obtain with high school degrees or GEDs. Some participants viewed attending college as a way to obtain jobs that would allow them to provide a higher quality of life for themselves and their children. They believed a higher quality life equated to fewer financial struggles. Participants believed by entering college, they would be able to have jobs that had a stable future demand and would allow them to work more appealing hours.

Another reason participants gave for entering college was to set positive examples for their children and younger siblings. The participants wish to serve as positive role models for their children or siblings by having more education. In addition, they hope their having degrees would provide more opportunities for their children. With their increased opportunities, the participants hope with the increased encouragement to attend college and increased financial resources their children will see attending college as more of an option.

The third major reason the participants gave for entering college was to achieve specific goals. The participants who had specific career goals entered college because the careers in which they were interested required college degrees. Other participants entered college because they wanted to improve themselves in general. They wanted to increase their knowledge levels 
as well as overcome the stigma they perceived they had for not being academically successful previously or for earning a GED and to have pride in and a sense of accomplishment in their jobs.

\section{Post-college entry.}

Academic involvement and integration. Tinto (1993) described students' first year in college as a time when they disassociate from their previous communities. However, Richardson and Skinner (1992) found that FGCS who attended community colleges typically attended parttime and were more likely than their classmates to have significant work and family responsibilities. Because community college students are not physically removing themselves from their previous communities, they may not be as likely to disassociate from them. As a result, the literature on academic integration may not fully apply to community college students, especially those at community colleges without residential facilities.

Academic challenges. The participants of the study demonstrated a wide range of academic preparation for college. Most of the participants entered college directly out of high school. Some participants entered college several years after graduating. Others dropped out of high school and later earned a GED before enrolling in college. In accordance with findings of other research studies (Chen \& Carroll, 2005; Horn \& Nunez, 2000; Humphrey, 2000; Terenzini et al., 1996), regardless of the different paths they took to college, the participants of this study for the most part were not prepared for college. They lacked knowledge about the academic content of college entry courses, lacked knowledge about the college environment, or both.

The participants' previous educational experiences did not prepare them for the academic content of their college classes. As Horn and Nunez (2000) and Humphrey (2002) reported is common with FGCS, several of the participants were not prepared for college and frequently 
struggled in at least one of their courses when they did enter college. Their lack of preparation was often the result of not taking appropriate coursework or not learning the material in their classes adequately.

The participants supported the findings of Humphrey (2002) that FGCS frequently recognize they are not prepared for college. Although many of the participants recognized they were not prepared for college, the reasons they gave for not being prepared varied. Few attributed their lack of preparation to previous educational institutions. Instead, they often attributed their lack of preparation to their own lack of skills. However upon review, they had not taken the appropriate classes to prepare them for college or did not learn the material sufficiently to be successful in college.

Humphrey (2002) reported FGCS often rate themselves as lacking in the academic skills they need for college. Many of the participants of the study supported this finding. However, not all of the participants who struggled in their classes recognized how unprepared they were. In spite of their self-assessments that they were prepared for college, several of the participants demonstrated they were not prepared for college level work.

Each of the participants described some sort of difficulty acclimating to the college environment. Although they did not directly say so, the experiences they described support reports that some FGCS feel overwhelmed with the unfamiliar environment of college (Richardson \& Skinner, 1992). Their descriptions of their experiences and their mannerisms suggested this was the case for several of the participants.

Institutions across the country are implementing strategies to increase student retention (Damashek, 2003). In order to overcome their academic challenges, the participants took advantage of multiple methods. One common method the participants used to address their 
academic challenges was to enroll in fewer courses. By enrolling in fewer courses each semester, they reported they had more time to devote to their individual classes.

Academic assistance resources. Another method participants used to address their academic challenges was to seek assistance with the content of their classes. They most frequently sought assistance from faculty members but also made use of academic resource centers, tutors, and peer study groups.

In order to overcome their academic deficiencies and difficulties, the participants found resources to help them be academically successful. In spite of the general variety of resources at their disposal, the participants of this study reported using a limited variety of resources. Most of the participants used only one or two resources. The highest number of resources any one participant used was three. The most common resources the participants referenced included campus resources, community members, and taking beginner coursework. Other resources participants cited were the internet, community members, family, friends, and high school teachers. However, these last resources were often only used by one participant each.

Campus resources proved to be one source of academic support for the participants. Most of the resources the participants used fell into the categories of developmental education or supplemental instruction. Developmental education is used to remediate academic deficiencies while supplemental instruction specifically focuses on classes that are difficult and provides the additional instruction necessary for students to master the material (Wild \& Ebbers, 2002). The most common campus resources participants cited using were academic resource centers, tutors, instructors, and peers. Although participants referenced campus resources, the specific resources they used varied from one person to the next. The most common campus resource the participants used was asking instructors for assistance. 
As well as seeking assistance from a variety of resources, how the resources helped the participants also varied. The participants described the resources as helpful because the people from the resource area provided more detailed explanations, explained the material in a different way, taught them new ways of learning the material, provided extra assignments to learn the material, taught them how to use technology to solve problems and learn answers, had group discussions about the materials, and gave pointers on what to study to learn the material better.

Developmental coursework. When students do not have the skills necessary to be academically successful, some enroll in developmental or remedial classes to learn those skills (Horn \& Berger, 2004; Kazis \& Liebowitz, 2003). In contrast to the findings of Van T. Bui (2002), the participants of this study typically remarked they believed they were prepared for the academic demands of college. When asked about their experiences with remedial or developmental courses, many of the participants of this study said they had not taken any of these courses. However, upon further comparison of the classes participants reported taking and those that were basic college level courses, many of the participants took classes that were lower than basic college level. Most of the participants of this study reported taking developmental or remedial courses. They reported either their scores on the placement tests reflected a need to take courses to prepare them for beginning college level work or based on self-assessment they made the decision to do so regardless of their placement test results. Even after taking developmental courses, more than one participant struggled in the topic areas.

The participants' reports of not having experience with developmental courses despite describing taking classes that were categorized as developmental or remedial may be in part due to a lack of understanding of what makes a class developmental or remedial. Few of the participants of the study were familiar with the terms developmental and remedial classes. More 
than one asked for an explanation of the term. In spite of their reports that they were academically prepared for college, their enrollment in developmental or remedial courses demonstrated they were not prepared for college level work.

The participants from SCC contradicted reports that students who do not have the skills to be successful enroll in developmental or remedial classes to learn the skills (Horn \& Berger, 2004; Kazis \& Liebowitz, 2003). On that campus, only two of the participants reported taking remedial classes. The other participants from that campus did not take remedial classes in spite of the fact the most of them reported struggling in their classes and demonstrated they were not prepared for the academic demands of college.

Interaction with faculty, staff, and administrators. Graunke and Woosley (2005) reported a there is a positive impact on persistence when students are satisfied with their opportunities to interact with faculty. Although students at community colleges may not interact with faculty, staff, and administrators frequently, this may not be an indicator they are dissatisfied with their opportunities to do so. The participants reported seldom interacting with faculty of their colleges. However, almost all of the participants expressed comfort in approaching faculty for assistance. The participants presented their lack of interaction with faculty as a result of their choice not to interact, not because they felt unwelcome to interact with the faculty.

In spite of their knowledge of the availability of academic support, many of the participants did not make full use of the services. Students" "egos" may prevent them from seeing academic support or being able to understand the reality of their situation. They most frequently sought assistance from their faculty. In addition, the participants did not support Humphrey's (2002) findings that FGCS rate themselves as below average in their academic abilities. The participants often described themselves as academically prepared for college. 
However, their lack of support for Humphrey's findings may be linked to Fallon's (1997) reports that few FGCS cite academic failure as their reason for leaving. Rather, they cite the stress of conflicting demands such of family, job, and finances (Fallon, 1997).

Although the majority of the out-of-class interactions the participants reported occurred with faculty and staff, it varied from one participant to the next and one college to the next how frequently the participants interacted with faculty. Many participants reported seldom interacting with faculty. One thread that was common to almost all of the participants regardless of the frequency they interacted with faculty was that the participants' out of class interactions with faculty members were typically limited to academic topics and focused on specific coursework.

The frequency of participant interactions with staff and administrators also varied from one campus to the next. However, regardless of the campus, even when the participants did interact with staff and administrators, their interactions focused on addressing specific academic needs. Their interactions centered on activities such as registration and financial aid processes, not their academic skills, interests, and needs. Although the participants described a limited number of interactions with faculty, staff and administrators and even fewer that were not academically oriented, they did not express discomfort with having interactions. They appeared to either believe they did not have the time to do so or believe it was not appropriate.

Based on their responses, most of the participants demonstrated they were integrated into the academic system of the college. With the exception of basic college level preparation, most of the participants described themselves as being academically successful and committed to their programs. For the remaining participants, the frequency of their seeking help from the faculty and tutoring center demonstrated their comfort with the academic climate of the college.

Attribution of success. The participants of the study attributed their success to a variety of 
sources outside of themselves as well as to characteristics about themselves. The external sources that participants believed led to their success included the quality of instructors at the college, the assistance of their families, the support they received from others including employers and the college, and the motivation of setting an example for their children. In spite of the wide range of external sources leading to their success, almost all of the participants credited personal characteristics at least in part to their success. They believed without their own efforts, determination, hard work, self-confidence, perseverance, and desire to learn, their educational success would not have been possible. Mary from CCGL (see Chapter 4) emphasized the role she believed personal characteristics play in the academic success of FGCS. She explained, "I think that to be successful, be a first-generation successful college student, it's got to come from within."

Social involvement and integration. Tinto's (1993) research about college students has also shown social integration plays a critical role in student success. Social integration provides support for students' college endeavors. Interactions with members of the campus community often help students feel supported in their attempts at college. Successful students typically receive support for their endeavors. Based upon the experiences of the participants in this study, the social integration literature may not fully apply to community college students, particularly those serving students in a large geographical area. The participants rarely interacted with members of their campus communities. In addition, they rarely expressed a desire to do so. Many of the participants seemed surprised at the idea they would interact with members of the campus community other than in their classes. Various participants had extensive outside obligations. They had family to take care of, worked many hours, and several commuted long distances. With their extensive outside responsibilities, they did not have the time to devote to the same activities 
a single, childless, 18 year old student with few other obligations could.

An area Tinto (1993) identified as critical to student persistence in college was that of social integration into college. According to (Joseph, 1995) an important component of students' persistence in college is the degree to which they are integrated into the social system of the college. For the purposes of this study, students' comfort level on campus, reported social challenges, and amount of out of class interaction with peers were used to understand their degree of social integration.

Comfort level. After the participants entered college, the social experiences they described differed from those of many non-FGCS. The participants of this study described being comfortable on campus and experiencing few social challenges. However, in contrast to many non-FGCS in the literature, they described very few out of class interactions with members of the campus community. In accordance with Pascarella et al.'s (2004) findings, the participants of this study reported very little involvement in campus organizations and only limited involvement in student activities. One part of Tinto's (1993) description of social integration relies on students forming personal bonds with students, faculty, and staff. Based upon their responses, most of the participants did not meet these criteria for being socially integrated into their colleges. They rarely interacted with students, faculty, and staff in order to form a personal bond with them.

Tinto and Love (1995) reported community college students struggle to feel comfortable on campus. The participants of this study did not support that finding. Most of the participants in this study reported feeling comfortable on their individual campuses. They referred to their comfort in terms of lack of problems on campus, a pleasing atmosphere in the community, and their knowledge of and similarities to other students. When asked directly if they were 
comfortable on campus, most of the participants said they were.

The participants repeatedly described being comfortable because of the environment of their respective campuses. Participants often attributed their comfort to the positive experiences with community members and a supportive campus atmosphere. The participants supported Graunke and Woosley's (2005) findings that students are impacted by the extent to which they believe faculty are concerned with their academic success. Participants often attributed their comfort to the positive experiences with community members and a supportive campus atmosphere.

Although they did not meet part of Tinto's (1993) criteria for social integration, they did perceive a match between their social values, preferences, and behavioral styles with other members of the community. Several participants attributed their comfort level on their campuses to their familiarity with and similarity to other students. Some participants believed they were comfortable because they had attended high school with other students. Other participants explained they had a great deal in common with other students.

Social Challenges. Also in support of Tinto's (1993) criteria requiring that students find a match between their social values, preferences, and behavioral styles with other members of the community for social integration, the participants cited few social challenges on campus. Some attributed their lack of challenges to personal characteristics while others attributed their lack of challenges to characteristics of the college and others cited a combination of the two. This in part supports Ridgell and Lounsbury's (2004) findings that personality traits could be used as a general predictor of performance.

While some participants reported they did not have any challenges, other participants did. Their experiences demonstrated they had not found a match between their social values, 
preferences, and behavioral styles with other members of the community as Tinto (1993) described for social integration. These participants often supported Richardson and Skinner's (1992) reports that FGCS at community colleges tend to have more significant work and family responsibilities in addition to supporting McClenney \& Green's (2005) assertion that they spend significantly more time caring for their dependents than their peers.

Interaction with peers. In spite of most of the participants reporting they were comfortable on campus, the frequency of social interactions with other students varied from campus to campus. Richardson and Skinner (1992) identified peer support as an important factor in student achievement and Pascarella et al. (2004) found FGCS often benefited more from involvement and peer interaction than did other students. Consistent with what Pascarella et al. (2004) described in their work, participants from two of the campuses, CCGL and CCA, reported very few social interactions and connections through the campus. They rarely socialized with other students and seldom participated in student organizations or activities. Participants at one college often described themselves as loners and "anti-social." Most of the participants from these two campuses did not belong to student organizations and did not participate in student activities. When they did interact with other students, it was typically for academically related reasons. The participants from the third campus disputed those same findings. They reported many more out of class interactions with other students. Not all of the participants from this campus were involved in student organizations but they all described participating in student activities to some extent.

Although the participants from only one campus demonstrated they were socially integrated into the campus, almost all of the participants felt supported in their pursuit of a college education. Upon being asked directly if they received support for attending college, most 
of the participants confirmed they were supported although the amount and source of support they received varied.

Support. Despite their reports of feeling supported, the participants of this study not only referred to few interactions with members of the campus community but also referred to few examples of support from family, friends, and community members. The experiences of these participants suggest FGCS may find support from different sources than their non-FGCS counterparts. Richardson and Skinner (1992) identified peer support as an important factor in student achievement. Participants reported very few social interactions and connections through the campus. They rarely socialized with other students and seldom participated in student organizations or activities. However, the participants of the study described feeling very supported in the college endeavors. Their support most often came from family members, not other students.

The experiences of the participants did not support research which says they have difficulty finding support for attending college (Richardson \& Skinner, 1992). Most of the participants of this study reported ample support for their college endeavors. However, unlike non-FGCS who receive a great deal of support from their peers (Pascarella et al., 2004), the participants of this study reported their biggest supporters were their families.

In many ways, the participants of this study contradicted reports that FGCS find it difficult to seek support (Copenhaver-Bailey, 2005; Richardson \& Skinner, 1992) but supported Zwerling's (1992) reported that first-generation adult students received more emotional support for their academic endeavors. The majority of the participants described being encouraged to attend college. However, for many of them, their encouragement did not arise until they were adults or nearly adults unlike their non-FGCS counterparts who typically are encouraged to 
attend college from a young age (Horn \& Nunez, 2000). In contrast to many previous reports, almost all of the participants in this study were able to reference some sort of support while they attended college. Non-FGCS are more likely to be involved in the campus community through extracurricular involvement (Pascarella et al., 2004) and more likely to form peer support groups (Richardson \& Skinner, 1992). In contrast, the sources of support for the participants of this study were outside of the campus community.

Non-FGCS find support from friends who are also attending college (Horn \& Nunez, 2000). This did not prove to be the case for the participants of this study. For most of the participants, their families served as major sources of support in their pursuits of a college education. Many of the participants explained their families, including significant others and children, provided some sort of support although that support varied from one participant to another. Their support included helping to reduce living expenses, providing moral support, providing childcare, giving pep talks, helping with academics, and demonstrating interest in their successes. Some families provided support by allowing participants to live with them so they could reduce expenses. Other families provided moral support by asking about classes and celebrating participants' successes with them. Some of the participants described their families helping them by providing childcare. Some of the participants referred to the support they received from their significant others. Their significant others helped with classes, took over extra family responsibilities, and provided encouragement.

Members of the campus community were another major source of support for some participants of the study. Some of the participants worked for the college they attended. Their coworkers and employers supported their desire to attend college and served as sources of support. Their support was the result of work relationships more than the result of campus affiliation. 
Other participants who did not work for the college still reported relying on members of the campus for support. These sources of support were on an individual basis, not as the result of intentional programs.

Although not a major source of support for most participants, some were also able to rely on the support of their friends as they attempted college. While this agrees in part with Horn and Nunez's (2000) reference to the importance of peer support, the support these participants received was frequently not from peers who were attending college which Hertel (2002) described as a significant prediction of overall adjustment and attachment to college. As a result, the participants' friends would not be able to provide the same degree of understanding to the challenges the participants encountered as students.

Tinto (1993) emphasized the importance of students being integrated into the social system of a college and interacting with their peers at college. The participants in this study described support not only from the college but also from family and significant others for their pursuit of a college education. Their responses supported Tinto's findings only in part. They described relying on a wide range of sources for their support that extended beyond the college. Their lack of interactions with other students and limited support from members of the campus community suggest the participants may not have been socially integrated into the campus.

Financial resources. In contrast to Horn and Nunez's (2000) findings that FGCS struggle to finance a college education, some participants reported they did not have financial challenges. Two of these participants referred to family financial resources that make attending college possible. Two other participants said they did not have any financial challenges. However, they both relied on some sort of financial assistance and had made choices based on limited financial resources which contradicted their self-reports. Their reliance on financial aid 
programs suggests they had more limited financial resources than they admitted.

The methods the participants used to address their financial challenges closely mirrored those identified in literature. As King (2003) reported is common with low-income students, the participants attempted to reduce their costs associated with attending college by applying for aid, working, and attending college part-time. Each of the participants described completing paperwork in order to be considered for various grants and scholarships. Most of the participants reported seeking employment to help address their financial concerns. A number of the participants reported working between 10 and 50 hours a week. A third way the participants attempted to address their financial concerns was to enroll on a part-time basis. They paid for their classes as they took them and only took as many classes as they could pay for at a time.

The participants of this study supported previous studies' descriptions of FGCS as lacking in financial resources (Horn \& Nunez, 2000; Humphrey, 2000). Each of the participants described limited financial resources even after they began college. They recounted struggles not only paying for college but also paying for basic living expenses. One participant described such a struggle with finances the previous year that she had difficulty paying for food and living expenses for her daughter and herself.

As Humphrey (2000) noted as common with FGCS, very few of the participants were able to rely on family finances to cover their expenses. The participants supported those findings. Instead they relied on a variety of other sources to obtain the money they needed to pay for college and for advice on how to obtain that assistance.

Nomi (2005) reported financial aid is a major source of funding for FGCS. The participants of this study supported those findings. Almost all of the participants reported receiving some sort of financial aid through scholarships, grants, and loans. The participants 
relied on financial aid programs to pay for tuition, uniforms, living expenses, and traveling expenses when they commuted to and from college. Without financial aid, many of the participants would not have been able to attend college.

Even with the assistance of financial aid, the participants struggled to find the financial resources they needed not only to attend college but also to cover living expenses. This is in accordance with data from the 2002 CCSSE. As a result, financial aid programs were not the only method participants used to pay for college. Other participants relied on state funded and federally funded programs to help meet their financial needs. Some participants referred to using state re-training programs, unemployment benefits, and low-income assistance.

Although the participants may have received financial aid through college, none of them found their financial aid eliminated their financial challenges. As King (2003) reported, the participants often made some sort of compromise or sacrifice in order to make attending college possible. In order to address their needs, many of the participants restricted their out of class activities and cut down on personal expenses. Other participants gave up the wages and benefits they received as full-time employees so they could attend college. More than one of the participants chose their colleges based on the expense related to attending. Some participants found it necessary to delay college until they were able to financially afford it. Several of the participants entered the military in order to have military benefits to pay for college. Other participants found it necessary to commute from long distances so they could reduce living costs and/or attend a less expensive college.

Another method many of the participants used to manage their financial demands was to work. Their experiences concur with reports that FGCS are more likely to be working and working more hours than their non-FGCS counterparts (Duggan, 2001; King, 2003; Pascarella et 
al., 2004). Several of the participants reported working between 10 and 50 hours a week to address their financial needs while attending college. This information is disconcerting when taken into consideration alongside reports that the more hours students work, the less likely they are to persist (Bers \& Smith, 1991.)

Financial Advice. In addition to their challenges in actually obtaining money for college, the participants also had also few sources to advise them on how to address their financial concerns. As King (2003) explained, FGCS sometimes make decisions based on inadequate information about possible consequences and available alternatives. The primary sources of assistance for the participants were the college's financial aid office, veteran's administration representative, and for a few of the participants, family members. The financial aid offices typically assisted the participants with completing paperwork. At two of the colleges, the financial aid office also took on additional tasks such as informing the participants of resources and methods to pay for college. These offices not only helped the participants to complete paperwork but also helped identify additional scholarships and grants in addition to identifying low-income assistance programs. Hughes (1990) found a significant correlation between students' satisfaction level with the financial aid office and whether or not the staff made the students feel comfortable. Most of the participants described the staff in the Financial Aid office in a positive way and expressed how helpful the staff was.

Several of the participants sought assistance from the Veterans' Administration Representative at their respective colleges. The representatives helped these participants access their G.I. Bills and on occasion, other financial aid programs such as the Pell Grant so the participants could begin college. The Veteran's Administration representatives also helped some of the participants make decisions with adequate information about possible consequences and 
available alternatives unlike participants King (2003) described who made decisions without adequate information.

Another source of financial assistance for a few participants was family. As Humphrey (2000) reported, very few of the participants received financial assistance from their families. Even among those who could ask family for help, their comfort level at seeking that assistance and type of assistance varied from one participant to another.

Goals and commitments. The participants were committed to meeting their educational goals. Their commitment to their education could be traced through their continued goals of attending college, satisfaction with and commitment to their college and programs, and desires to complete their programs in a timely manner.

Post-entry goals. Most of the participants altered their goals between when they originally began college and when they participated in the study. A few of the participants decided to earn degrees requiring less time while almost half of the participants who changed their goals set ones that would require more education and an almost equal number of participants changed their goals to different fields that required the same educational level. Those who made changes to their goals believed the changes they made were better aligned with their life goals, skills, and interests. With their changes came increased commitments to their goals.

Some participants had specific career aspirations while others had goals that were more general in nature. Although their level of details about their plans varied, each of the participants had ideas on how they wanted to use their degrees. Many of the participants described specific jobs they wanted to obtain. Other participants had general ideas about the jobs they wanted to have and focused more on the type of job they wanted to have.

Post-entry commitments. The current method of obtaining retention and persistence data 
may not accurately reflect the experiences of community college students. McClanahan (2004) reported the three-year graduation rates at two-year institutions had reached a twenty year low by 2003. However, other research (Copenhaver-Bailey, 2005; King, 2003; Richarson \& Skinner, 1992) reported FGCS and older students were more likely to enroll on a part-time basis. Students who are enrolled on a part-time basis will not be likely to complete Associate's Degrees in three years. With the added knowledge that they also tend to work more hours and have more family responsibilities, colleges should not expect them to complete their degrees in the same time frame as a full-time student with no other responsibilities.

Students who are committed to an institution or program are more likely to persist (Bers \& Smith, 1991; Tinto 1993). While several of the participants had originally enrolled at other institutions, they all reported being committed to and satisfied with the education they received at their colleges. Most of the participants reported they would still enroll at their college if they had to make the choice again. Some indicated they would do so because of the college's location and convenience but others referred to the employees and academic programs as motivating them to re-enroll. The participants consistently referred to their colleges as supportive, comfortable, helpful, and convenient.

Most of the participants also reported they would choose the same major or program if they had to re-enter college. They frequently described their programs as a good fit for their skills and interests. In addition, some participants reported they would choose the same program because of the positive reputation it had in the region. Their responses indicate the participants were academically integrated. Bers and Smith (1991) reported academic integration was one of the factors that distinguished students who persisted with those who did not.

Cofer and Somers (2000) reported students enrolled as full-time were more likely to 
persist. The participants of the study supported these findings only in part. Of the 24 participants (Table 4) in the study, 19 were enrolled on a full-time basis and most reported they typically enrolled on a full-time basis. Based upon the status of these students, the participants were committed to completing their programs in a timely manner. However, other participants were not enrolled on a full-time basis but gave every indication they were committed to completing their degrees. Some of the participants reported they chose not to enroll on a full-time basis in order to accommodate family and work responsibilities. Participants had significant work and family responsibilities as Richardson and Skinner (1992) and McClenney \& Green (2005) reported. They often referred to their concerns they would not be adequately fulfilling their responsibilities if they devoted more time to classes and studying.

Table 4

Participant age ranges by college

Total

CCGL $\quad$ CCA $\quad$ SSC $\quad$ Number

\begin{tabular}{|c|c|c|c|c|c|}
\hline Male & $18-22$ & 0 & 1 & 2 & 3 \\
\hline & $23-29$ & 1 & 1 & 0 & 2 \\
\hline & $30-39$ & 0 & 0 & 0 & 0 \\
\hline & $40+$ & 0 & 1 & 1 & 2 \\
\hline \multirow[t]{4}{*}{ Female } & $18-22$ & 1 & 1 & 1 & 3 \\
\hline & $23-29$ & 3 & 3 & 1 & 7 \\
\hline & $30-39$ & 0 & 2 & 0 & 2 \\
\hline & $40+$ & 1 & 2 & 2 & 5 \\
\hline Total & & 6 & 11 & 7 & 24 \\
\hline
\end{tabular}


One characteristic that was common to most of the participants hinted at the possibility they could have difficulty in completing their educational goals was the amount of time and effort they expended on studying. Terenzini et al., 1996 found although FGCS are not academically prepared for college and gain more than their non-FGCS counterparts gain by studying, they are less likely to do so. As a group, the participants spent little time preparing for their classes. Many of the participants who were enrolled on a full-time basis spent very little time preparing for their classes. Even those participants who were enrolled on a full-time basis often spent less than 10 hours a week preparing for their classes.

\section{Similarities and Differences Across Sites}

The participants of this study described many similar experiences regardless of the site where they were located. They shared similar experiences in their preparation for college, their source of academic assistance, their interactions with members of the campus community, and their reliance on financial aid.

Most of the participants from all three sites described struggling with the academic content of their classes as well as having difficulty adjusting to the college environment. The participants at all three sites described difficulty with the content of their Math and English classes most frequently. In addition, they typically did not know what to expect from the college environment. They were unprepared for the demands upon their time and the need for them to be a self-directed learner.

When the participants encountered academic difficulties, they tended to use the same sources for assistance. The most common source of academic assistance on all three campuses was faculty. Although some participants cited other sources of academic assistance, faculty was the common thread of assistance across all three campuses. 
Most of the participants on all three campuses described limited financial resources. Regardless of which campus the participant called home, they relied on financial aid programs to attend college. However, participants on all three campuses reported the financial aid they received rarely addressed all of their financial concerns.

In spite of the many similarities of their experiences, there were a number of differences in the experiences of the participants from one site to another. Their differences centered on academic challenges as well as social integration and financial resources.

Although most of the participants from all three sites discussed academic challenges, not all of them addressed their challenges by enrolling in remedial courses. The participants at CCGL, and CCA who described academic difficulties consistently enrolled in developmental classes. However, few of the participants at SCC enrolled in developmental classes even though they also reported struggling with the content of their classes.

Participants from all three campuses described seeking help from their academic resource center and tutors. However, the participants at CCA and SCC described more success in obtaining assistance from their academic resource centers and tutors than did the participants at CCGL. The participants from CCA and SCC referred to their experiences with the academic resource centers in positive manners. The participants from CCGL on the other hand often either did not refer to the academic resource center and tutoring services or did so in a negative way.

Another difference between sites related to participants' familiarity with campus resources. The participants at SCC described the widest range of academic assistance resources available on their campus. They described access to university sponsored academic assistance resource centers in addition to specialized academic assistance programs focused on the needs of particular high risk groups of students. 
The participants from the three sites did not dedicate the same amount of time and effort to preparing for their classes. The participants at SCC reported spending more time preparing for classes and studying than the participants at the other two campuses. They reported the most consistent hours of studying. Four of the participants described studying 10 to 20 hours a week. The participants at CCGL reported the fewest hours per week studying. Many of them reported studying less than 10 hours a week even though many were enrolled as full-time students.

The participants of the three sites did not share the similar experiences with student organizations and activities. Participants from CCGL and CCA were seldom involved in student organizations or activities. However, the participants at SCC often took part in student groups and activities.

Another difference between sites was regarding the participants' experiences with the financial aid offices. The participants at CCA and SCC described the staff in their financial aid offices helping them complete paperwork as well as helping them identify additional financial resources. This was not true of the participants of CCGL. Those participants discussed the financial aid office helping them complete paperwork but nothing else. The participants at CCGL describe much lower satisfaction with their financial aid experiences.

\section{Lessons Learned}

Being unfamiliar with community colleges, I learned a number of lessons during this study. The first lesson I learned was regarding the lack of community college participation. In spite of the large number of requests I made to conduct my study, very few institutions granted permission. Many simply did not respond while others declined to participate. The reasons the colleges gave for not wishing to participate included being in the midst of their own studies, being in the midst of reaccreditation, and believing their students had been the subject of too 
many studies.

Another lesson was in regards to the availability of data about students. I anticipated the colleges would be able to access a great of information about their students. Knowing that a high percentage of FGCS attend community colleges and often need additional assistance to be successful, I thought colleges would gather this information so they could target those students most in need of assistance. However, I discovered during my pilot study that community colleges did not track if their students were FGCS and how many of their students were FGCS.

I also learned there are many opportunities and services offered at the community colleges. I was pleasantly surprised to learn that the colleges offered a number of academic assistance services such as academic skills centers, tutoring, supplemental instruction, and even federal programs such as TRIO and Pathways. The colleges that participated in the study provided student assistance programs that were comparable to those available at many larger institutions.

\section{Implications for Action}

As a part of the interview protocol, I asked the participants for suggestions of how colleges could help FGCS be more successful. While some of their suggestions mirrored my own thoughts, they also had suggestions I had not considered. The implications that follow are combinations of my own suggestions and some of the participants' suggestions.

Research based recommendations. With the extensive research detailing how unprepared FGCS are for college, the ideal step would be for colleges to intervene in that preparation. Colleges need to do more to reach out to secondary school students. They need to work with secondary schools to educate middle-school and high school students on how to prepare for college reinforcing the importance of their grades and attendance to college 
admission. In addition, students need to know what to expect when they do attend college and financial assistance options. Without that knowledge, middle and high school students may believe college is not an option for them and not adequately prepare for the academic challenges of college.

Colleges need to do more to help FGCS make the transition to college. They could do this with outreach initiatives with students' families, educating FGCS on where to get assistance, and ensuring all entering students are able to use the technology required in the classrooms. Incorporating family members in students' college experiences could be very beneficial for students and colleges. The participants of this study demonstrated relying most on their families for support. By incorporating students' families, the families would be more knowledgeable about what the students are encountering and thus may be able to provide more support and more assistance when the students face challenges. In addition, by incorporating the students' families more regularly, students could potentially feel more integrated into the campus. This step could also potentially benefit the colleges by possibly recruiting other members of the family to attend the same college since they would be more familiar with the environment.

Knowing many FGCS are not prepared for the environment they will encounter, colleges need to do more to reach out to those students and help them make the transition to college. Participants of this study reported they did not participate in orientation and college success seminars. Colleges need to find a way to pass knowledge on to the students. Students need to be educated on what to expect from college, from whom to seek advice, how college will be different from previous schooling such as high school, how to prepare for class, and how to be organized in spite of juggling many responsibilities.

Colleges need to reevaluate and potentially revise how they are offering student services 
on their campuses. Because FGCS are balancing so many responsibilities, the traditional methods of offering classes and other services may not be appropriate or beneficial for them. Colleges need to explore the possibility of offering classes and services in less traditional manners such as on weekends, later in the evening, earlier in the morning, on-line, and on a drop in basis as opposed to scheduled appointments.

The most critical steps community colleges can take to help FGCS be successful are to identify the students who need assistance and to provide nurturing support for the students. Colleges need to identify FGCS in a similar manner to how they track other students who may be at risk of non-completion. Without this knowledge, colleges cannot expect to provide services and meet the needs of FGCS. Secondly, faculty, staff, and administrators who represent the colleges need to maintain their compassion for the students they serve and remember the challenges these students face as they attempt to bridge the gap between their past and a promising future.

Professional experience based recommendations. As a higher education administrator with more than 20 years of experience working with students, while I listed to the participants describe their experiences I recognized there were some areas where colleges could be more helpful to students. Colleges need to review what type of assistance their campus offices are providing to students and assess if those offices are meeting the needs of the students. Based on the reports of the participants of this study, only two of the campuses offered assistance in identifying financial resources. Knowing that FGCS often have limited financial resources and limited resources to provide advice, it behooves colleges to fill that gap. In addition, participants from more than one campus expressed a desire to have more career matching services such as career advising and career shadowing so students can learn about possible careers. With a high 
proportion of community college students being non-traditional and having family responsibilities, colleges need to assess how they help students with responsibilities such as childcare. They need to explore the potential of offering childcare service on or near the campus at a low cost.

With community colleges appealing to so many non-traditional students, they need to evaluate how they are helping these students acclimate to the environment and meet the academic demands of college. Non-traditional and re-entry students may not have had the same exposure to learning technology of recent high school graduates. Colleges need to ensure they are educating all incoming students on how to use campus technology.

In general, colleges need to assess how they can provide the best education to their students. People living in rural areas may have more limited access to educational opportunities. Community colleges in more rural areas could explore increased educational opportunities for their constituents. They may be able to collaborate with nearby four-year colleges to offer additional programs and classes. In addition, community colleges could consider providing college credit for military courses in a similar manner to many four-year colleges.

\section{Recommendations for Further Research}

Although the findings of this study has helped shed light on the challenges and aspirations of FGCS, they were not able to address everything about members of this group. As researchers explore the experiences and needs of FGCS, there are a number of areas that need further review.

In spite of their knowledge of various academic services such as tutors, academic skills centers, and faculty, the participants of this study rarely made full use of these services. Future research needs to explore why students do not make full use of campus resources. Is there a 
stigma to using these services? Are the students uncomfortable admitting they need help? Do the participants believe the services would be helpful to them?

Future research needs to explore the experiences and needs of FGCS in relation to their primary life roles. As Kim, Sax, Lee, and Hagedorn (2010) explain, community college students are a diverse group. It is possible that the multiple roles students have may shape their educational goals, experiences, and beliefs.

Participants from single campuses identified different available services and activities. Future research needs to explore why students' perspectives of available service are so varied. In addition, research needs to explore the consistency of students' perspectives of available services and colleges' perspectives of what service they offer. Why did participants of a single college have such a variety of perceptions of what services were offered? Were the services and activities students believed were offered the only ones offered? Why was there a discrepancy?

Because there has been little research on Tinto's theory of student departure as it applies to community college students, research needs to explore its applicability to community college students. Do social and academic integration serve as critical a role for community college students as they do for residential four-year institutions? Does this importance vary based on students' personal characteristics? Does this importance vary based on students' perceptions of their primary life role?

Researchers need to review and possibly modify how retention and persistence rates are determined. Research has identified how the enrollment patterns of community college and especially FGCS, differs from non-FGCS. With this knowledge it may be a disservice to use three-year graduation rates to determine retention and persistence of students when research has shown these students often do not enroll on a full-time basis. 


\section{References}

Alexander, F. K. (2002). The federal government, direct financial aid, and community college students. Community College Journal of Research and Practices, 26, 659-679.

Alexander, F. K. (1998). Public dollars and private institutions. Journal of Education Finance, 23(3) 390-416.

Aloi, S. L. (2004). The use of assessment data in academic strategic planning. (West Virginia University). ProQuest Dissertations and Theses. 324 p.

http://search.proquest.com/docview/305109663? accountid=6444

American College Testing, Incorporated. (1998a). National college dropout and graduation rates, 1997. Retrieved from http://www.act.org/news/releases/1998/04-01b98.html

American College Testing. (1998b). New low for graduation rate, but dropout picture brighter. Retrieved from http://www.act.org/news/releases/1998/04-01-98.html.

Aud, S., Hussar, W., Johnson, F., Kena, G., Roth, E., Manning, E., Wang, X., and Zhang, J. (2012). The condition of education 2012 (NCES 2012-045). U. S. Department of Education, National Center for Education Statistics. Washington, DC. Retrieved from: http://nces.ed.gov/pubserarch.

Auerbach, C. F. \& Silverstein, L. B. (2003) Qualitative data: An introduction to coding and analysis. New York: New York University Press.

Bailey, T. R. \& Alfonso, M. (2005, January). Paths to persistence: An analysis of research on program effectiveness at community colleges. Retrieved from http://www.luminafoundation.org/publications/PathstoPersistence.pdf.

Baime, D.S., \& Mullin, C. M. (2011, July). Promoting educational opportunity: The Pell Grant program at community colleges (Policy Brief 2011-03PBL). Washington, DC: American 
Association of Community Colleges.

Beck, C. T. (2009, October). Critiquing Qualitative Research. AORN Journal, 90(4), 543-554.

Berkner, L. \& Choy, S. (2008). Descriptive summary of 2003-04 beginning postsecondary students: Three years later (NCES 2008-174). Washington DC: U.S. Department of Education.

Bers, T. H. \& Smith, K.E. (1991, October). Persistence of community college students: The influence of student intent and academic and social integration. Research in Higher Education, 32(5), 539-556.

Billson, J. M. \& Terry, M. B. (1982, Fall). In search of the silken purse: Factors in attrition among first-generation students. College and University, 59(1), 57-75.

Billson, J. M. \& Terry, M. B. (1987, Summer). A student retention model for higher education. College and University, 62(4), 290-305.

Boggs, G. R. (2011, May-June). The American community college: From access to success. About Campus, 16(2), 2-10.

Braxton, J. M., Hirschy, A. S., \& McClendon, S. A. (2004) Understanding and reducing college student departure. ASHE-ERIC Higher Education Report: 30(3), Hoboken, NJ: Wiley.

Carnegie Foundation for the Advancement of Teaching. (2000). Carnegie Classification of Higher Education. Retrieved from http://www.carenegiefoundation.org/classifications Carnegie Foundation for the Advancement of Teaching. (2005). Carnegie Classification of Higher Education. Retrieved from http://www.carnegiefoundaiton.org/classifications Carnegie Foundation for the Advancement of Teaching. (2007). Carnegie Classification of Higher Education. Retrieved from http://www.carnegiefoundaiton.org/classifications Carnegie Foundation for the Advancement of Teaching. (2009). Carnegie Classification of 
Higher Education. Retrieved from http://www.carnegiefoundaiton.org/classifications Carnegie Foundation for the Advancement of Teaching. (2011). Carnegie Classification of Higher Education. Retrieved from http://www.carnegiefoundaiton.org/classifications Carnegie Foundation for the Advancement of Teaching. (2012). Carnegie Classification of Higher Education. Retrieved from http://www.carnegiefoundaiton.org/classifications

Chen, X. \& Carrol, C.D. (2007). First generation students in postsecondary education: A look at their college transcripts. Washington DC: U.S. Department of Education, National Center for Education Statistics.

Chitty, Haley (2008, January). Customer service in the financial aid office: Campus lessons learned from the traditional rules of service. University Business, 11(1), 25-26.

Choy, S. (2001). Students whose parents did not go to college: Postsecondary access, persistence, and attainment (NCES 2001-126). Washington DC: U.S. Department of Education.

Cofer, J. \& Somers, P. (2000, December). Within-year persistence of students at two-year colleges. Community College Journal of Research \& Practice, 24(10), 785-807.

Cofer, J. \& Somers, P. (2001, Winter). What influences student persistence at two-year colleges? Community College Review, 29(3), 56-77.

Cohen, A. M. \& Brawer, F. B. (1996). The American community college ( $3^{\text {rd }}$ ed). San Francisco, CA: Josey-Bass, Inc. (ED389384)

Community College of Appalachia (CCA). (2009). Course Catalog. Community College of the Great Lakes (CCGL). (2007). Course Catalog Community College Survey of Student Engagement (CCSSE). (2002). Engaging community colleges: A first look. Retrieved from http://www.ccsse.org/publications/report.pdf. 
Community College Survey of Student Engagement (CCSSE). (2005). Engaging students, challenging the odds: 2005 findings. Retrieved from http://www.ccsse.org/publications/report.pdf.

Copenhaver Bailey, B. (2005). Impact of the West Virginia University Student Support Services/TRIO program from 1998--2004. West Virginia University). ProQuest Dissertations and Theses, $108 \mathrm{p}$. http://search.proquest.com/docview/305421515?accountid=6444

Corrigan, M. E. (2003, Spring). Beyond access: Persistence challenges and the diversity of lowincome students, New Directions for Higher Education, 121, 25-35.

Cresswell, J.W. (2003). Research design: Qualitative, quantitative, and mixed methods approaches $\left(2^{\text {nd }}\right.$ ed).Thousand Oaks, CA: Sage.

Culp, M. M. (2005, Fall). Increasing the value of traditional support services. New Directions for Community Colleges, 131, 33-49.

Damashek, R. (2003). Support programs for students on academic probation. Retrieved from ERIC database. (ED035 812)

Doughtery, K. (2001). State policies and the community college's role in workforce preparation. In B. K. Towsend \& S. B. Twombly (Eds.), Community colleges: Policy in the future context (pp. 129-148). Westport, CT: Ablex.

Duggan, M. (2001, November). Factors influencing the first-year persistence of first generation college students. Retrieved from ERIC database. (ED459673)

Duggan, M. H. \& Williams, M. R. (2011). Community college student success courses: The student perspective. Community College Journal of Research and Practice, 35, 121-134.

Elkins, S. A., Braxton, J. M., \& James, G. W. (2000). Tinto’s separation stage and its influence 
on first-semester college student persistence. Research in Higher Education, 41(2), 251268.

England - Siegerdt, C. (2011). Do loans really expand opportunities for community college students? Community College Journal of Research and Practice. 35(1-2), 88-98.

Fallon, M. V. (1997, May). The school counselor's role in first generation students' college plans. School Counselor, 44(5), 384-394.

Fraenkel, J.R. \& Wallen, N.E. (2000). How to design and evaluate research in education (4 ed.). Boston, MA:McGraw-Hill.

Graunke, S. S. \& Woosley, S. A. (2005, June). An exploration of the factors that affect the academic success of college sophomores. College Student Journal, 39(2), 367-377.

Hertel, J. B. (2002). College student generational status: Similarities, differences, and factors in college adjustment, The Psychological Record, 52, 3-18.

Horn, L. \& Berger, R. (2004). College persistence on the rise?: Changes in 5-year degree completion and postsecondary persistence rates between 1994 and 2000. National Center for Education Statistics, Postsecondary Education Descriptive Analysis Reports: US Department of Education: Institute of Education Sciences. Retrieved from ERIC database. (ED483066)

Horn, L. \& Nunez, A. M. (2000, March). Mapping the road to college: FGCS' math track, planning strategies, and context of support. NCES 2000-153 Washington D.C.: National Center for Education Statistics; U.S. Department of Education. Retrieved from: http://nces.ed.gov/pubsearch/pubsinfo.asp?pubid=2000153

Hudley, C., Moschetti, R., Gonzalez, A., Cho, S., Barry, L., \& Kelly, M. (2009, Spring). College freshmen's perceptions of their high school experiences. Journal of Advanced Academics, 
$20(3), 438-471$

Hughes, R. (1990, April). The financial aid experience of ethnic students: Is it a boon or barrier? Retrieved from ERIC database. (ED364147)

Humphrey, E. (2000). An ex-post facto study of first generation students (Master's thesis). Retrieved from: http://scholar.lib.vt.edu/theses/available/etd-0427200011440049/unrestricted/ETDHumphrey.pdf

Ishitani, T. T. (2005, June). Studying educational attainment among first-generation students in the United States. Presented at the $45^{\text {th }}$ annual forum of the Association for Institutional Research. June 1, 2005. San Diego, CA.

Joseph, L. K. (1995). Institutional persistence of first-generation students. Doctoral Dissertation, West Virginia University, 1995.

Kazis, R. \& Liebowitz, M. (2003). Opening doors to earning credentials: Curricular and program format innovations that help low-income students succeed in community colleges. Retrieved from ERIC database. (ED475990)

Kennamer, M. \& Katsinas, S. (2011). An early history of the rural community college initiative: Reflections on the past and implications for the future. Community College Journal of Research and Practice, 35, 234-351.

Kim, K. A., Sax, L. J., Lee, J. J., \& Hagedorn, L. S. (2010) Redefining nontraditioinal students: Exploring the self-perceptions of community college students. Community College Journal of Research and Practice. 34, 402-422.

King, J. E. (2003, Spring). Nontraditional attendance and persistence: The cost of students' choices. New Directions For Higher Education, 2003(121), 69-84.

Kotamraju, P. \& Blackman, O. (2011) Meeting the 2020 American Graduation Initiative (AGI) 
goal of increasing postsecondary graduation rates and completions: a macro perspective of community college student educational attainment. Community College Journal of Research and Practice. 35(3), 202-219.

Levin, J. S. (1997). The cultures of the community college. Retrieved from ERIC database. (ED415799)

Levin, J.S., Cox, E. M., Cerven, C., \& Haberler, Z. (2010). The recipe for promising practices in community colleges. Community College Review. 38(1), 31-58.

McClanahan, R. (2004). Review of retention literature. What works in student retention? Appendix 1, Retrieved from http://www.act.org/path/policy/reports/retain.html.

McClenney, K.M. \& Green, T. (2005). A tale of two students: Building a culture of engagement in the community college. About Campus. 10, 2-7. doi:10.1002/abc.129.

McConnell, P. J. (2000, Winter). What community colleges should do to assist first-generation students. Community College Review, 28(3), 75-87.

Miller, M. T. \& Tuttle, C. C. (2007) Building communities: How rural community colleges develop their communities and the people who live in them. Community College Journal of Research and Practice, 31(2), 117-127.

Mullin, C. M. (2010, June). Rebalancing the mission: The community college completion challenge (Policy Brief 2010-02PBL). Washington, DC: American Association of Community Colleges.

Murray, Melissa (2008, August). When war is work: The G.I. Bill, citizenship, and the civic generation. California Law Review, 96(4), 967-998.

National Center for Educational Statistics (NCES). (1999). Digest of education statistics table and figures. Retrieved from http://nces.ed.gov/programs/digest/d96/ 
National Center for Educational Statistics (NCES) (2000). Percentage distribution of undergraduates, by the highest level of educational completed by either parent: 19992000. Retrieved from http://nces.ed.gov/das/library/tables_listings/nedrc_table.asp?sbj=parent\%20education. National Center for Educational Statistics (NCES). (2005a, June). The condition of education 2005 (NCES 2005-094). Washington, DC: U.S. Government Printing Office. Retrieved from http://nces.ed.gov/pubsearch/pubsinfo.asp?pubid=2005094

National Center for Educational Statistics (NCES) (2005b, July) First-generation students in postsecondary education: A look at their college transcripts. Retrieved from http://nces.ed.gov/pubs2005/2005171.pdf

Neutzling, E. (2003). Crossing the finish line: A strategic approach designed to help community college students persist and graduate. Retrieved from ERIC database. (ED474579)

Nomi, T. (2005). Faces of the future: A portrait of first-generation community college students. Washington DC: American Association of Community Colleges. Retrieved from ERIC database. (ED493531)

Nora, A., Attinasi, Jr., L.C., \& Matonak, A. (1990, Spring) Testing qualitative indicators of precollege factors in Tinto's attrition model: A community college student population. The Review of Higher Education, 13(3), 337-356.

Nunez, A. M., \& Cuccaro-Alamin, S. (1998, June) First-generation students: Undergraduates whose parents never enrolled in postsecondary education. National Center for Education Statistics: U.S. Department of Education.

O’Banion, T. ( 2011, August/September) Pathways to completion: Guidelines to boosting students success. Community College Journal, 82(1), 28-34. 
Palomba, C \& Banta T. (1999). Assessment essentials: Planning, implementing, and improving assessment in higher education. San Francisco, CA: Jossey Bass.

Pascarella, E. T., Pierson, C. T., Wolniak, G. C., \& Terenzini, P. T. (2004). First-generation college students: Additional evidence on college experiences and outcomes. The Journal of Higher Education, 75(3), 249-284.

Patton, M. Q. (2002). Qualitative research \& evaluation methods $\left(3^{\text {rd }}\right.$ ed). Thousand Oaks, CA: Sage.

Richardson, R. C. \& Skinner, E. F. (1992, Winter). Helping first-generation college students achieve degrees. New Directions for Community Colleges, 20(4), 29-43.

Ridgell, S. D., and Lounsbury, J. W. (2004, December). Predicting academic success: General intelligence, "big five” personality traits, and work drive. College Student Journal, 38(4), 607-619.

Roberts, C. M. (2004). The dissertation journey: A practical and comprehensive guide to planning, writing, and defending your dissertation. Thousand Oaks, CA:Corwin Press.

Snyder, T. D. (1999). Digest of Education Statistics, 1999. East Lansing, MI: National Center for Research on Teacher Learning. Retrieved from ERIC database. (ED436861)

Snyder, T. D. \& Dillow, S. A. (2012). Digest of Education Statistics 2011 (NCES 2012-001). National Center for Education Statistics, Institute of Education Sciences, U.S. Department of Education. Washington, DC. Retrieved from: http://nces.ed.gov/pubserarch.

Southern Community College (SCC). (2011). Course Catelog.

Strauss, A. L. \& Corbin, J. M. (1990). Basics of qualitative research: Grounded theory procedures and techniques, 2(23). Thousand Oaks, CA:Sage. 
Terenzini, P. T., Springer, L., Yaeger, P. M., Pascarella, E. T., \& Nora, A. (1996). Firstgeneration college students: Characteristics, experiences, and cognitive development. Higher Education, 37(1), 1-22.

Tinto, V. (1975). Dropout from higher education: A theoretical synthesis of recent research. Review of Educational Research, 45, 89-125.

Tinto, V. (1993). Leaving college: Rethinking the causes and cures of student attrition. Chicago, IL: University of Chicago Press.

Tinto, V. \& Love, A.G. (1995, February) A longitudinal study of learning communities at LaGuardia Community College. Washington, DC: Office of Educational Research and Improvement.

Torres, C. \& Evans, R. (2005, Fall). Contemporary community colleges: Presidential perspectives. The Community College Enterprise, 11(2), 69-79.

United States Census Bureau. (2012). 2010 Census Urban and Rural Classification and Urban Area Criteria. Retrieved from http:/www.census.gov/geo/www/ua/2010urbanruralclass.html

United States Census Bureau. (2012). State and county quick facts. Retrieved from http://quickfacts.census.gov/qfd/index.html

Van T. Bui, K, (2002, March). First-generation college students at a four-year university: Background characteristics, reasons for pursuing higher education, and first-year experiences. College Student Journal, 36(1), 9-12.

Vogt, W. P., \& Johnson, B. (2011). Dictionary of statistics and methodology: A nontechnical guide for the social sciences. Thousand Oaks, CA: SAGE

Weiss, R. S. (1994). Learning from strangers: The art and method of qualitative interview 
studies. New York, NY: Free Press.

Wild, L. \& Ebbers, L. (2002). Rethinking student retention in community colleges. Community College Journal of Research and Practice, 26, 503-519.

Zwerling, L. S. (1992, Winter). First-generation adult students: In search of safe havens. New Directions for Community Colleges, 20(4), 45-54. 


\title{
Appendix A
}

\author{
Pilot Study Permission Request Letter
}


(West Virginia University Letterhead)

(Date)

Dear (Name):

I am a doctoral student in the Educational Leadership Program at West Virginia University in Morgantown, West Virginia. I am currently working on my dissertation research study and will be exploring how first generation college students are being helped to reach their educational goals. My study is designed to identify how first-generation college students have been successful. This study will yield information which will assist postsecondary institutions to better understand first-generation college students and how to assist them in their success.

I will be conducting a pilot study during early August to identify issues with the cover letter and interview protocol. I would like to interview first-generation college students regarding their experiences at college who have following characteristics:

- Within the first generation of their immediate family to attend college;

- Enrolled in any program of study which culminates in a degree or certification;

- Either part-time or full-time enrollment;

- Completed more than half of the courses in their program for degree or certification completion;

- Completed the majority of their courses at the institution in which they are currently enrolled;

- Males and females equally represented among the students;

- Traditional (18 to 22 years) as well as non-traditional age (over 22 years) students. 
The purpose of this letter is to request permission to interview four to five students from your college and to request assistance in identifying and obtaining contact information for 15 students with these characteristics. Once students have been identified, I will send students a letter outlining the study and inviting them to participate. When students agree to participate, I will schedule times to meet with them. The interviews should last no more than 45 to 60 minutes. With the student's permission, I will audio tape the interviews but will destroy the tapes after the information on the tapes has been transcribed.

In addition, I am requesting general institutional data about student finances and academic skills. Student financial data I am requesting is types and quantity of financial assistance provided through grants, scholarships, and loans. Academic skill data I am requesting is institutional data on developmental or remedial and repeat course-taking.

Individual students will remain anonymous and the information I obtain from students will be aggregated. Your name and any other information that may identify participants and institutions will not be revealed in the reported results and will remain confidential. Student participation will be entirely voluntary. I look forward to getting to know more about your institution and students. Please respond by July 10, 2006 and inform me of your decision. If you have any questions, please feel free to contact me.

Sincerely,

Jenny Waters

Doctoral Student

jwaters1@mix.wvu.edu 
Appendix B

Pilot Study Institution Permission Letter 
(Institution Letterhead)

(Date)

Dear Ms. Waters,

I am writing to indicate my support for your doctoral dissertation research at (Institution Name). I will provide you with a list of names and addresses for 15 of our students who: 1) are within the first generation of their immediate family to attend college; 2) will be enrolled for a program of study leading to a degree or certification; 3) are either part- or full-time students; 4) have completed at least half of the courses in their program with a majority of the credits being from this institution, and 5) include male and female traditional and non-traditional students.

I understand that you will send each student a letter outlining your study and inviting him or her to participate. I also understand that you will arrange interview times which should last no longer than 45 to 60 minutes. You have agreed to emphasize to the students that their participation is voluntary and that they have the right to not respond to any item. Student participation in your study will not affect their class standing, grades, or membership in any student organization or athletic team. You have also agreed that you will not release students' names or any other identifying information as their responses are to remain confidential.

Sincerely,

(Name) 
(Title)

(Institution) 


\section{Appendix C}

Pilot Study Interview Protocol 


\section{Interview Protocol}

Institution:

Participant:

Thank you for agreeing to participate in my study. The goal of my study is to learn what is happening to help first-generation college students be successful. I will ask you questions about your experiences in college. All of the information I obtain will be used for my doctoral dissertation.

With your permission, I would like to audiotape our interview to make sure I do no miss anything you say. If I do tape the interview, the tapes will be destroyed once the interview is transcribed.

Before we start, I want to point out several things:

a) Your participation is entirely voluntary and you do not have to respond to every question;

b) Your specific answers will remain anonymous and confidentiality will be maintained;

c) Your class standing, athletic status, and grades will not be affected by refusing to participate or withdrawing from the study.

d) May I tape the interview?

Yes

No

1. How old are you?

2. What ethnic group(s) do you identify with?

3. What is your household's yearly income range?

4. When do you primarily take classes? (Day, evening, both, online)

5. What is your enrollment status? (Full or part-time)

6. What was your mother's highest level of education?

7. What was your father's highest level of education? 
8. Do you have siblings?

a. If yes, have they attended college and completed a degree or certificate program?

b. How many?

9. Why did you decide to attend college?

10. How many credits have you completed at \{current institution\}?

11. How many remaining credits do you need to enroll in to complete your degree, certificate, or transfer to another institution?

12. When did you begin your enrollment at this college? (Semester and year)?

a. When you first decided to attend college, what were your goals?

13. Have these goals changed?

14. What do you plan to do with this degree/certification?

15. What are the major academic challenges you have faced in attending college?

16. How prepared were you for the academic demands of college?

17. How did you gain the academic skills needed for college?

18. What experience have you had with developmental or remedial classes?

19. Where have you gone for help when you have had difficulties in classes? How do these resources help you?

20. What are the major social challenges you have faced in attending college?

21. Within the past year, who have you interacted with outside of class and how frequently have you interacted with each group?
a. Students
b. Staff 

c. Administrators
d. Faculty

22. When you have encountered social challenges, where have you gone for help or who has helped you? How did they help you?

23. Who first encouraged you to attend college? When?

24. Who have been the biggest supporters of you attending college?

25. Have any of your friends or parents questioned your decision to attend college?

26. How comfortable have you been as a student at this college?

27. What student groups or organizations do you belong to?

28. What student activities have you participated in during this past year?

29. What are the major financial challenges you have faced in attending college?

30. How have you managed the financial demands of attending college?

31. Where have you gone when you needed help with financial concerns about college? How did they help you?

32. To what would you attribute your success?

33. When do you plan to complete your degree, certification, or transfer to another institution?

34. If you were to go back to the beginning of college, would you make the same decisions?

35. Would you enroll at this same institution? Why?

36. Would you enroll in the same program/major? Why? 


\section{Appendix D}

Study permission request letter 
(West Virginia University Letterhead)

(Date)

Dear (Name):

I am a doctoral student in the Educational Leadership Program at West Virginia University in Morgantown, West Virginia. I am currently working on my dissertation research study and will be exploring how first generation college students are being helped to reach their educational goals. My study is designed to identify how first-generation college students have been successful. This study will yield information which will assist postsecondary institutions to better understand first-generation college students and how to assist them in their success.

I will be conducting a pilot study during October to identify issues with the cover letter and interview protocol. I would like to interview first-generation college students regarding their experiences at college who have following characteristics:

- Within the first generation of their immediate family to attend college;

- Enrolled in any program of study which culminates in a degree or certification;

- Either part-time or full-time enrollment;

- Completed more than half of the courses in their program for degree or certification completion;

- Completed the majority of their courses at the institution in which they are currently enrolled;

- Males and females equally represented among the students;

- Traditional (18 to 22 years) as well as non-traditional age (over 22 years) 
students.

The purpose of this letter is to request permission to interview 10 students from your college and to request assistance in identifying and obtaining contact information for 45 students with these characteristics. Once students have been identified, I will send students a letter outlining the study and inviting them to participate. When students agree to participate, I will schedule times. The interviews should last no more than 45 to 60 minutes. With the student's permission, I will audio tape the interviews but will destroy the tapes after the information on the tapes has been transcribed.

In addition, I am requesting general institutional data about student finances and academic skills. Student financial data I am requesting is types and quantity of financial assistance provided through grants, scholarships, and loans. Academic skill data I am requesting is institutional data on developmental or remedial and repeat course-taking.

Individual students will remain anonymous and the information I obtain from students as well as institutions will be aggregated. Your name and any other information that may identify participants and institutions will not be revealed in the reported results and will remain confidential. Student participation will be entirely voluntary. I look forward to getting to know more about your institution and students. Please respond by September 30, 2006 and inform me of your decision. If you have any questions, please feel free to contact me.

Sincerely,

Jenny Waters

Doctoral Student 
jwaters1@mix.wvu.edu 
Appendix F

\author{
Study Institution Permission Letter
}


(Institution Letterhead)

(Date)

Jenny Waters

106 Berry Lane

Marietta, $\mathrm{OH} 45750$

Dear Ms. Waters,

I am writing to indicate my support for your doctoral dissertation research at (Institution Name). I will provide you with a list of names and addresses for 45 of our students who: 1) are within the first generation of their immediate family to attend college; 2) will be enrolled for a program of study leading to a degree or certification; 3) are either part- or full-time students; 4) have completed at least half of the courses in their program with a majority of the credits being from this institution, and 5) include male and female traditional and non-traditional students.

I understand that you will send each student a letter outlining your study and inviting him or her to participate. I also understand that you will arrange interview times which should last no longer than 45 to 60 minutes. You have agreed to emphasize to the students that their participation is voluntary and that they have the right to not respond to any item. Student participation in your study will not affect their class standing, grades, or membership in any student organization or athletic team. You have also agreed that you will not release students' 
names or any other identifying information as their responses are to remain confidential.

Sincerely,

(Name)

(Title)

(Institution) 
SUCCESSFUL FIRST-GENERATION COLLEGE STUDENTS

\title{
Appendix G
}

\author{
Study Participant Request Letter
}


(Date)

(Student Name)

(Street)

(City, State Zip)

Dear (Student Name):

I am a doctoral student in the Educational Leadership Program at West Virginia University in Morgantown, West Virginia. I am currently working on my dissertation research study and will be exploring how first generation college students are being helped to reach their educational goals. My study is designed to identify how first-generation college students have been successful. This study will yield information which will assist postsecondary institutions to better understand first-generation college students and how to assist them in their success. As a student, your responses would be very helpful in helping me to identify common experiences among students not only at your college but also at other community colleges. If you would be willing to discuss your college experiences with me, please complete the attached form so we can schedule a time to talk that is convenient for you. Please respond by October 15, 2006.

Once I complete the study, I will compile the information all of the students have provided and will write a summary as a part of my dissertation. Again, please be assured that no one other than me will have access to your specific responses. If you have any questions, please feel free to contact me at jwaters1@mix.wvu.edu. If you are willing to participate in this study, please send me an e-mail with the information. 

A. Your name
B. The best time to contact you and
C. The best method of contacting you along with your e-mail and phone number.

As you consider this request, I want to point out several things:

Your participation is entirely voluntary and you do not have to respond to every question;

Your specific answers will remain anonymous and confidentiality will be maintained;

Your class standing, athletic status, and grades will not be affected should you choose not to participate in this study.

Thank you in advance for helping me with this study.

Sincerely,

Jenny Waters 


\section{Appendix $\mathbf{H}$}

Study Interview Protocol 


\section{Interview Protocol}

Institution:

Participant:

Thank you for agreeing to participate in my study. The goal of my study is to learn what is happening to help first-generation college students be successful. I will ask you questions about your experiences in college. All of the information I obtain will be used for my doctoral dissertation.

With your permission, I would like to audiotape our interview to make sure I do no miss anything you say. If I do tape the interview, the tapes will be destroyed once the interview is transcribed.

Before we start, I want to point out several things:

a) Your participation is entirely voluntary and you do not have to respond to every question;

b) Your specific answers will remain anonymous and confidentiality will be maintained;

c) Your class standing, athletic status, and grades will not be affected by refusing to participate or withdrawing from the study.

d) May I tape the interview?

$$
\text { Yes }
$$

No

1. How old are you?

2. What ethnic group(s) do you identify with?

3. What is your household's yearly income range?

4. When do you primarily take classes? (Day, evening, both, online)

5. What is your enrollment status? (Full or part-time) 
6. What was your mother's highest level of education?

7. What was your father's highest level of education?

8. Do you have siblings?

a. If yes, have they attended college and completed a degree or certificate program?

b. How many?

9. Why did you decide to attend college?

10. How many credits have you completed at \{current institution\}?

11. How many remaining credits do you need to enroll in to complete your degree, certificate, or transfer to another institution?

12. When did you begin your enrollment at this college? (Semester and year)?

13. When you first decided to attend college, what were your goals?

a. Have these goals changed?

14. What do you plan to do with this degree/certification?

15. What are the major academic challenges you have faced in attending college?

16. How prepared were you for the academic demands of college?

17. How did you gain the academic skills needed for college?

18. What experience have you had with developmental or remedial classes?

19. Where have you gone for help when you have had difficulties in classes? How do these resources help you?

20. What are the major social challenges you have faced in attending college?

21. Within the past year, who have you interacted with outside of class and how frequently have you interacted with each group? 

a. Students
b. Staff
c. Administrators
d. Faculty

22. When you have encountered social challenges, where have you gone for help or who has helped you? How did they help you?

23. Who first encouraged you to attend college? When?

24. Who have been the biggest supporters of you attending college?

25. Have any of your friends or parents questioned your decision to attend college?

26. How comfortable have you been as a student at this college?

27. What student groups or organizations do you belong to?

28. What student activities have you participated in during this past year?

29. What are the major financial challenges you have faced in attending college?

30. How have you managed the financial demands of attending college?

31. Where have you gone when you needed help with financial concerns about college? How did they help you?

32. To what would you attribute your success?

33. When do you plan to complete your degree, certification, or transfer to another institution?

34. If you were to go back to the beginning of college, would you make the same decisions?

35. Would you enroll at this same institution? Why?

36. Would you enroll in the same program/major? Why? 


\section{Appendix I}

West Virginia University Institutional Review Board Approval 


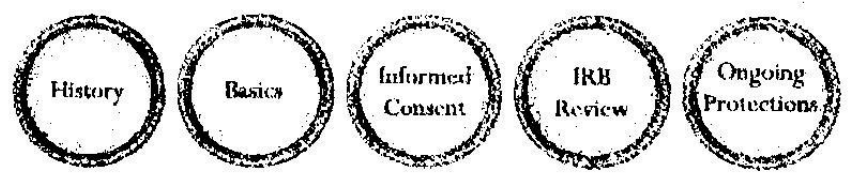

Jennifer A. Waters has completed this course at West Virginia University.

Date of completion: $05 / 30 / 03$

Spceific topics addressed include:

- Roles and responsibilitics of researchers and their key personnel

- Guiding cthical principles for rexearch

- Federal regulations

- Informed consent

- Institutional review boards

- Ongoing protections throughout the course of the study

- Data and safety monitoring

- Reporting of adverse events

- Privacy and confidentiality

- Historical events that have impacted policy and legislation

Research Compliance Officc West Virginia University 


\section{Appendix J}

CCGL Participants 
Linda, who was 18 at the time of the study, is a single white student. Her father earned a GED and her mother graduated high school and attended college for two semesters before dropping out when she became pregnant with Linda. Linda graduated from a nearby high school and attends college with many of her high school acquaintances.

Mary is a married white mother of three. At the time of the study, Mary was 23. Her mother graduated high school and received additional training through the U.S. Navy. Mary's adoptive father also graduated high school. When Mary became pregnant at the age of 14, she dropped out of school. When she was 18 , her husband began encouraging her to earn her GED so she could attend college.

Barb is a single white mother who lives with her significant other. She was 46 at the time of the study and had returned to college for the third time after being laid off from her job twice within a three-year period. Her mother graduated high school and her father dropped out of school after the eighth grade. Of her four siblings, one earned a technical certificate from a trade school and one earned an Associate's degree.

Jim is a single white student who was 24 at the time of the study. His father graduated high school and his mother earned an Associate's degree after he entered college. He had one sibling who earned certification in a trade skill. Jim re-entered college for the third time after two unsuccessful attempts at other colleges.

Patty is a multiracial single mother who identified herself as Hispanic, White, and Native-American. She is the only child of a mother who graduated from high school and attended one semester of college. Patty was 26 at the time of the study.

Liz is a single White mother. At the time of the study, she was 27 years old. Her mother and father both graduated high school. Of her four siblings, two began college but did not 
complete degrees. 


\section{Appendix K}

\section{CCA Participants}


Susan is a married mother of three who was 36 at the time of the study. Both of her parents earned GEDs. One of Susan's siblings dropped out of college after a year and two younger siblings started attending community colleges where they lived. Susan works approximately 20 hours a week at the college and commuted approximately 30 miles to and from the college.

Margaret is a single, White, student who was 50 at the time of the study. Her father dropped out of high school after the eighth grade and her mother did so after the tenth grade. Although she is one of several children, none of her siblings attended college. She lived in the local area with her parents.

Dorothy, who was 21 at the time of the study, is a married White mother. Her mother left high school after her junior year and Dorothy believes her father attended college but does not know what he studied. Her older brother pursued technical training after high school and her younger sister plans to attend college to study nursing.

Lisa is a White, divorced mother of a teenage son and participated in the study when she was 45 years old. She believes her mother left school after tenth grade. Her father died when she was a teenager and she does not know his highest level of education. Both of Lisa's sisters attended college and one was a registered nurse. She worked at the family owned business prior to her return to college and divorce.

Nancy is an Asian-American single mother who was 24 at the time of the study. Her mother completed high school and her father began college but dropped out. She has one brother who started college but started working and dropped out of college.

Karen is a White married mother. She was 32 at the time of the study. Both of her parents earned high school diplomas. She previously earned an Associate's degree in business and 
shortly before the study, returned to college to earn a degree in a different field.

Betty is a White single student who was 28 at the time of the study. Both of her parents graduated high school and continued their training after high school although they never pursued additional formal education. Her brother earned a Bachelor's degree and her sister attended college for two and a half years before leaving school.

Helen is a White, single mother who participated in the study when she was 25 years old. Her mother and father both graduated high school and her father continued receiving training through his job. Her brother began attending a technical school but she did not know if he had earned a degree or not.

Bob is a Hispanic male who lives with his parents. He was 20 years old at the time of the study. Both of his parents graduated high school and neither attended college. His younger sister is planning to attend college and is collecting college information packets.

Dave is a married, White, father of three who works a full-time job in addition to attending college. He participated in the study when he was 30 years old. His parents are high school graduates with four sons; Dave being the only son to attend college.

Mike, is a White immigrant who was 44 when he participated in the study. His mother has the European equivalent of an Associate's degree and his father has trade school training from Europe. Mike’s stepsister earned a Bachelor's degree in Psychology. 
SUCCESSFUL FIRST-GENERATION COLLEGE STUDENTS

Appendix L

SCC Participants 
Sandra, who was 21 at the time of the study, is a Native-American, White, and Hispanic mother of three children. Her mother completed the eighth grade and her father left school before finishing the sixth grade. Sandra is one of three biological siblings and seven adoptive siblings and the only one to attend college. She dropped out of public school and finished her high school level education through home schooling and earned a GED. She earned the GED during what would have been her seventh grade year.

Bill is a multi-racial single father who was 40 at the time of the study. He believed his mother finished either the ninth or tenth grade and his father the seventh or eighth grade. Bill's father later earned a GED after he left the military. Bill is one of 11 children and the only one to attend college. He entered college after leaving the military.

Lenny is an African-American single student who was 19 at the time of the study. She believed her mother may have taken some college classes but knew her mother had not earned a degree. Lenny also believed her father attended college but was not sure how much. She is one of 12 children and the only one to pursue a college education.

Donna is a white single student who was 60 at the time of the study. Her mother and father stopped attending school while they were in high school. Donna did not believe either graduated high school. She is the eldest of 11 children and the only one to attend college.

Chuck is a white, single student who was 19 at the time of the study. His mother graduated high school and began college but did not complete a degree or certificate. His father finished the third grade. He has one older sister who began college but dropped out three weeks into the first semester. He dropped out school when he was in the ninth grade and earned a GED while he was incarcerated as a juvenile.

Carol, who was 24 when she participated in the study, is a White single mother. Her 
mother dropped out of school after the ninth grade and her father graduated high school. She is one of five children. Her younger brother was enrolled in college but she would be the first to earn a degree. Carol originally entered college directly after high school but was in car accident after her first semester. As a result of the accident, she was not able to perform the physical labor demanded of her degree. She reentered college when she recuperated enough to be able to do the work.

Ruth was a married, White mother who was 54 at the time of the study. Her mother and father both graduated high school. She is one of three children and the only one to attend college. She had already earned a Bachelor's degree and was pursuing a Master's degree. Ruth began her education at another college and dropped out after her first year. She began working at SCC and took an occasional class. She earned her Associate's degree from SCC and at the time of the study worked for the college. 